\title{
Synthesis of bowl-shaped polycyclic aromatic compounds and homo-bi-dentate 4,5-diarylphenanthrene ligands
}

\author{
Daehwan Kim \\ West Virginia University
}

Follow this and additional works at: https://researchrepository.wvu.edu/etd

\section{Recommended Citation}

Kim, Daehwan, "Synthesis of bowl-shaped polycyclic aromatic compounds and homo-bi-dentate 4,5-diarylphenanthrene ligands" (2008). Graduate Theses, Dissertations, and Problem Reports. 4391. https://researchrepository.wvu.edu/etd/4391

This Dissertation is protected by copyright and/or related rights. It has been brought to you by the The Research Repository @ WVU with permission from the rights-holder(s). You are free to use this Dissertation in any way that is permitted by the copyright and related rights legislation that applies to your use. For other uses you must obtain permission from the rights-holder(s) directly, unless additional rights are indicated by a Creative Commons license in the record and/ or on the work itself. This Dissertation has been accepted for inclusion in WVU Graduate Theses, Dissertations, and Problem Reports collection by an authorized administrator of The Research Repository @ WVU.

For more information, please contact researchrepository@mail.wvu.edu. 
Synthesis of Bowl-shaped Polycyclic Aromatic Compounds and Homo-bi-dentate 4,5-Diarylphenanthrene Ligands

\author{
Daehwan Kim
}

\begin{abstract}
Dissertation
Submitted to the Eberly College of Arts and Sciences at West Virginia University in partial fulfillment of the requirements for the degree of Doctor of Philosophy in Organic Chemistry
\end{abstract}

\author{
Kung K. Wang, Ph. D., Chair \\ Peter M. Gannett, Ph. D. \\ John H. Penn, Ph. D. \\ Michael Shi, Ph. D. \\ Björn C. Söderberg, Ph. D. \\ C. Eugene Bennett Department of Chemistry
Morgantown, West Virginia
2008

Keyword: Schmittel cyclization, enyne-allenes, bowl-shaped polycyclic aromatic hydrocarbons, $\mathrm{C}_{2}$-symmetrical homo-bi-dentate ligands Copyright 2008 Daehwan Kim 


\section{ABSTRACT \\ Synthesis of Bowl-shaped Polycyclic Aromatic Compounds and Homo-bi-dentate 4,5-Diarylphenanthrene Ligands}

\section{Daehwan Kim}

A new synthetic pathway leading to buckybowls was developed via cascade cylizatiom reactions of benzannulated enyne-allenes. The convergent assembly of the benzannulated enediynyl propargylic alcohols and the efficient cascade cyclizations of the resulting enyne-allenes leading to polycyclic aromatic dibromides for subsequent palladium-catalyzed intramolecular arylation reactions are the key features of this synthetic pathway. Three new buckybowls with their structures confirmed by X-ray structure analyses were thus synthesized.

Polycyclic aromatic hydrocarbon bearing ten fused ring system was successfully synthesized by using diindeno-fused $4 \mathrm{H}$-cyclopenta[def]phenanthrene prepared from the thionyl chloride-induced cascade cyclization reactions of the corresponding enediynyl propargylic alcohols. Direct tandem Knoevenagel condensation and hydrogenation efficiently furnished the diketones as precursors of propargylic diols for cascade cyclizations. Only five steps were involved in producing aromatic dibromides or diiodides as precursors for the buckybowls containing more than 44 carbons of $\mathrm{C}_{60}$.

The synthetic pathway to the twisted polycyclic aromatic hydrocarbons bearing 4,5-diphenylphenanthrene moeity via the Schmittel reaction was successfully adopted for the synthesis of $\mathrm{C}_{2}$-symmetrical homo-bi-dentate ligands. Demethylation followed by derivatization with camphorsulfonyl group could convert enantiomers of 4,5-di(4-methoxyphenyl)phenanthrene derivatives to the corresponding diastereomers, which are separable on silica column chromatography. Similarly, 4,5-di(4-aminophenyl)phenanthrene was likewise synthesized. 
Dedicated to

My parents and my daughter, Sarah D. Kim 


\section{ACKNOWLEDGEMENT}

It is my great pleasure to express my sincere gratitude and respect for my advisor, Dr. Kung K. Wang, for his support, patience, constant encouragement and practical suggestions during the course of my dissertation research. I was a very fortunate student to meet such an outstanding chemist and too nice, mild, broad-minded, and patient teacher. I am greatly benefited by his great interest, and extensive knowledge of chemistry.

I would also like to express my gratitude to my research committee members, Dr. Peter M. Gannett, Dr. Michael Shi, Dr. John H. Penn, and Dr. Björn C. Söderberg for their helpful suggestions, patience, and valuable discussions that improved the contents of this dissertation.

My special thanks go to Dr. Jeffrey L. Petersen for his valuable help and excellent work in X-ray structure analysis.

My special thanks also go to Dr. Novruz Akhmedov for his help with the NMRs and various structure analyses of my compounds.

I would also like to thank the former and present group members, Dr. Weixiang Dai, Dr. Hua Yang, Dr. Yanzhong Zhang, Lily Wang, Hu Cui, Bo Wen, Elbin Parbin and Ruoxin Zhang for their help and support.

I take the opportunity to thank the entire faculty, staff, and graduate students for their encouragement and help in a variety of ways.

My deepest gratitude goes to my parents for their love, support and encouragement that have made this dissertation possible.

Financial support from the C. Eugene Bennett Department of Chemistry of West Virginia University and the National Science Foundation is also gratefully acknowledged. 


\section{Table of Contents}

Title Page $\quad$ i

Abstract

$\begin{array}{lll}\text { Dedications } & \text { iii }\end{array}$

Acknowledgement iv

Table of Contents $\quad$ V

List of Figures viii

List of ${ }^{1} \mathrm{H}$ NMR and ${ }^{13} \mathrm{C}$ NMR Spectra $\quad$ ix

\section{Chapter I}

\section{Cyclization Reactions of Enyne-Allenes}

1. Introduction 1

1.1. Structure of enediynes 1

1.1.1. Endiynes with a nine-membered ring core structure 2

1.1.2. Endiynes with a ten-membered ring core structure 3

1.2. Research orientation to enediynes 5

1.3. The Bergman Cyclization of Enediyne System 5

1.4. Various cyclizations: The Moore Cyclization; Myers Cyclization; The Schmittel $\begin{array}{ll}\text { Cyclization and the Myers-Saito Cyclization } & 7\end{array}$

1.4.1. Moore cyclization: Enyne-Ketenes $\quad 8$

1.4.2. Myers-Saito $\left(\mathrm{C}^{2}-\mathrm{C}^{7}\right)$ Cyclization: Enyne-Allenes 9

1.4.3. Schmittel $\left(C^{2}-C^{6}\right)$ Cyclization: Enyne-Allenes $\quad 10$

1.4.4. Various effects on Myers-Saito $\left(C^{2}-C^{7}\right)$ Cyclization and Schmittel $\left(C^{2}-C^{6}\right)$ $\begin{array}{ll}\text { Cyclization } & 11\end{array}$

1.4.5. Heteroaromatic compounds via $C^{2}-C^{6}$ cyclization $\quad 13$

1.4.6. The Concerted and diradical mechanism of enyne-allene reaction 14

1.5. Literature survey on the preparation of enyne-allenes or enyne-cumulenes 16 


\section{Chapter II}

Synthesis of Bowl-Shaped Polycyclic Aromatic Hydrocarbons via Palladium-Catalyzed Intramolecular Arylation Reactions

1. Introduction

2. Literature survey on the Synthesis of bowl-shaped polycyclic aromatic hydrocarbons 21

3. Research Objective 24

4. Results and Discussion 25

$\begin{array}{ll}\text { 5. Conclusion } & 30\end{array}$

\section{Chapter III}

Synthesis of $\mathrm{C}_{2}$-Symmetrical homo-bi-dentate Ligands

Bearing a 4,5-Diarylphenanthrene Moiety

1. Introduction 31

2. Research Objective 32

3. Results 34

3.1. Synthesis of a diindeno-fused 4,5-diarylphenanthrene containing phenolic groups 34

3.2. Resolution of 4,5-diarylphenanthrene containing phenolic groups 36

3.2.1. Literature survey for resolution 36

3.2.2. Results of resolution 38

3.3. Low stability of diphenol-substituted phenanthrene 42

3.4. $\mathrm{C}_{2}$-Symmetrical homo-bi-dentate 4,5-diarylphenanthrene ligands containing orthoand meta-substituents $\quad 45$

3.5. Para-aniline substituted $\mathrm{C}_{2}$-symmetrical homo-bi-dentate product BINAM 47

4. Conclusion 49 


\section{Chapter IV}

Attempted Synthesis of an Indeno-Fused Corannulene via Cascade Cyclizations of Benzannulated Enyne-Allenes 50

2. Research Objective 57

3. Results and Discussion 58

3.1. Synthesis of all fused polycyclic aromatic hydrocarbons containing corannulene $\begin{array}{ll}\text { moiety } & 54\end{array}$

3.2. Fused polycyclic aromatic hydrocarbons via intramolecular alkylation 56

3.3. Attempted synthesis of fused polycyclic aromatic hydrocarbons via intramolecular

3.4. Attempted synthesis of pentaindenocorannulene 203

4. Conclusion

\section{Chapter V \\ Experimental Section}

Instrumentation, Materials and Manipulation $\quad 64$

$\begin{array}{ll}\text { References } & 94\end{array}$ 


\section{List of Figures}

Figure 1. Structure of calicheamicin.

Figure 2. Structures of enediynes containing a nine-membered ring core.

Figure 3. Structures of enediynes containing a ten-membered ring core.

Figure 4. Moore: Enyne-Ketenes, Bergman: Ene-Diynes, Myers: Enyne-Cumulenes, Myers-Saito: Enyne-Allenes, and Schmittel: Enyne-Allenes.

Figure 5. Various bowl-shaped polycyclic aromatic hydrocarbons.

Figure 6. ORTEP drawings of the crystal structure of 133.

Figure 7. POAV1 pyramidalization angles $\left(\Theta_{\sigma \pi}-90\right)$ of $\mathbf{1 1 1}$ and 133.

Figure 8. Synthesis of Bowl-shaped PAHs 148 from ketone 144.

Figure 9. ORTEP drawing of the crystal structure of $\mathbf{1 4 8 b}$.

Figure 10. POAV1 pyramidalization angles of 148a and $\mathbf{1 4 8 b}$.

Figure 11. A variety of $\mathrm{C}_{2}$-symmetrical homo-bi-dentate ligands.

Figure 12. 4,5-Disubstituted phenanthrenes.

Figure 13. ORTEP drawings of 4,5-diarylphenanthrene 157a.

Figure 14. 4,5-Diarylphenanthrene bearing helical twisted phenolic groups.

Figure 15. ORTEP drawing of the crystal structure of 163.

Figure 16. Chiral acyl chlorides for the resolution of BINOL.

Figure 17. ${ }^{1} \mathrm{H}$ NMR spectra of camphorsulfonates 175.

Figure 18. ORTEP drawing of the crystal structure of the di-methylated 176.

Figure 19. ${ }^{1} \mathrm{H}$ NMR spectra of camphorsulfonates 178.

Figure 20. NMR spectrum of decomposition of compound 176. 
Figure 21. ${ }^{1} \mathrm{H}$ NMR Spectrum of three sets of ABs from methylene hydrogens of 198.46

Figure 22. ${ }^{1} \mathrm{H}$ NMR Spectra of diastereomeric sulfonamide. $\quad 48$

Figure 23. 1D TOCSY spectrum of compound 240 . 58

Figure 24. nOe of compound 247.

Figure 25. nOe of compound 240. 60

Figure 26. ORTEP drawing of the crystal structure of Buckybowl 148a. 105

Figure 27. ORTEP drawing of the crystal structure of 4,5-diphenolicphenanthrene 177.105

Figure 28. ORTEP drawing of the crystal structure of Dibromoketone 252. 106

Figure 29. ORTEP drawing of the crystal structure of Diiodoketone 254. 106

\section{List of ${ }^{1} \mathrm{H}$ and ${ }^{13} \mathrm{C}$ NMR Spectra}

${ }^{1} \mathrm{H}$ and ${ }^{13} \mathrm{C}$ NMR Spectra of Compound $136 \quad 107-108$

${ }^{1} \mathrm{H}$ and ${ }^{13} \mathrm{C}$ NMR Spectra of Benzannulated Enediyne 137

${ }^{1} \mathrm{H}$ and ${ }^{13} \mathrm{C}$ NMR Spectra of Compound 138

${ }^{1} \mathrm{H}$ and ${ }^{13} \mathrm{C}$ NMR Spectra of Benzannulated Enediyne 139

${ }^{1} \mathrm{H}$ and ${ }^{13} \mathrm{C}$ NMR Spectra of Compound 132

${ }^{1} \mathrm{H}$ and ${ }^{13} \mathrm{C}$ NMR Spectra of Buckybowl $133 \quad 117-118$

${ }^{1} \mathrm{H}$ and ${ }^{13} \mathrm{C}$ NMR Spectra of Hydrocarbon $143 \quad 119-120$

${ }^{1} \mathrm{H}$ and ${ }^{13} \mathrm{C}$ NMR Spectra of Compound 145a 121-122

${ }^{1} \mathrm{H}$ and ${ }^{13} \mathrm{C}$ NMR Spectra of Benzannulated Enediyne 146a $\quad 123-124$

${ }^{1} \mathrm{H}$ and ${ }^{13} \mathrm{C}$ NMR Spectra of Compound 147a 125-126

${ }^{1} \mathrm{H}$ and ${ }^{13} \mathrm{C}$ NMR Spectra of Buckybowl 148a $\quad 127-128$

${ }^{1} \mathrm{H}$ and ${ }^{13} \mathrm{C}$ NMR Spectra of Hydrocarbon 149a 129-130 
${ }^{1} \mathrm{H}$ and ${ }^{13} \mathrm{C}$ NMR Spectra of Compound $\mathbf{1 4 5 b}$

${ }^{1} \mathrm{H}$ and ${ }^{13} \mathrm{C}$ NMR Spectra of Benzannulated Enediyne 146b

${ }^{1} \mathrm{H}$ and ${ }^{13} \mathrm{C}$ NMR Spectra of Compound 147b

${ }^{1} \mathrm{H}$ and ${ }^{13} \mathrm{C}$ NMR Spectra of Buckybowl 148b

${ }^{1} \mathrm{H}$ and ${ }^{13} \mathrm{C}$ NMR Spectra of Hydrocarbon $149 \mathrm{~b}$

${ }^{1} \mathrm{H}$ and ${ }^{13} \mathrm{C}$ NMR Spectra of Propargylic diols 159

$141-142$

${ }^{1} \mathrm{H}$ and ${ }^{13} \mathrm{C}$ NMR Spectra of Diiodide 160

$143-144$

${ }^{1} \mathrm{H}$ and ${ }^{13} \mathrm{C}$ NMR Spectra of 4,5-Di(4-methoxyphenyl)phenanthrene 163

${ }^{1} \mathrm{H}$ Spectrum of Camphorsulfonate $\mathbf{1 7 5}$

${ }^{1} \mathrm{H}$ and ${ }^{13} \mathrm{C}$ NMR Spectra of Diastereomer P-175 or M-175

${ }^{1} \mathrm{H}$ and ${ }^{13} \mathrm{C}$ NMR Spectra of Diastereomer P-175 or M-175

${ }^{1} \mathrm{H}$ and ${ }^{13} \mathrm{C}$ NMR Spectra of Methylated 4,5-di(4-methoxyphenyl)phenanthrene 176 152-153

${ }^{1} \mathrm{H}$ and ${ }^{13} \mathrm{C}$ NMR Spectra of Methylated 4,5-diphenolicphenanthrene 177

${ }^{1} \mathrm{H}$ and ${ }^{13} \mathrm{C}$ NMR Spectra of Methylated 4,5-di(3-methoxyphenyl)phenanthrene 196 156-157

${ }^{1} \mathrm{H}$ and ${ }^{13} \mathrm{C}$ NMR Spectra of 4,5-Di(2-Methoxyphenyl)phenanthrene 198

$158-159$

${ }^{1} \mathrm{H}$ and ${ }^{13} \mathrm{C}$ NMR Spectra of 4,5-Di(4-Aminophenyl)phenanthrene 201

$160-161$

${ }^{1} \mathrm{H}$ and ${ }^{13} \mathrm{C}$ NMR Spectra of Sulfonamide 202

$162-163$

${ }^{1} \mathrm{H}$ and ${ }^{13} \mathrm{C}$ NMR Spectra of Diastereomer P-202 or M-202

164-165

${ }^{1} \mathrm{H}$ and ${ }^{13} \mathrm{C}$ NMR Spectra of Diastereomer P-202 or M-202

$166-167$

${ }^{1} \mathrm{H}$ and ${ }^{13} \mathrm{C}$ NMR Spectra of 2-(1,3-Dimethoxypropyl)-1,3-indandione (234)

168-169

${ }^{1} \mathrm{H}$ and ${ }^{13} \mathrm{C}$ NMR Spectra of 2-Methyl-2-(1,3-dimethoxypropyl)-1,3-indandione (232)

${ }^{1} \mathrm{H}$ and ${ }^{13} \mathrm{C}$ NMR Spectra of Propargylic diols 235

$170-171$

${ }^{1} \mathrm{H}$ and ${ }^{13} \mathrm{C}$ NMR Spectra of Dimethoxy compound 236

$172-173$

${ }^{1} \mathrm{H}$ and ${ }^{13} \mathrm{C}$ NMR Spectra of Dibromide 231

${ }^{1} \mathrm{H}$ and ${ }^{13} \mathrm{C}$ NMR Spectra of 2-Tetrahydropyranyl-1,3-indandione (244)

176-177

${ }^{1} \mathrm{H}$ and ${ }^{13} \mathrm{C}$ NMR Spectra of 2-Methyl-2-tetrahydropyranyl-1,3-indandione (245)

178-179

${ }^{1} \mathrm{H}$ and ${ }^{13} \mathrm{C}$ NMR Spectra of Propagylic diols 246

$180-181$

${ }^{1} \mathrm{H}$ and ${ }^{13} \mathrm{C}$ NMR Spectra of Tetrahydropyranyl compound 242 
${ }^{1} \mathrm{H}$ and ${ }^{13} \mathrm{C}$ NMR Spectra of Diiodide 241

${ }^{1} \mathrm{H}$ and ${ }^{13} \mathrm{C}$ NMR Spectra of Polycyclic Aromatic Hydrocarbon 240 and 247

${ }^{1}$ H NMR Spectra of Polycyclic Aromatic Hydrocarbon 247 (aliphatic region) 190

${ }^{1}$ H NMR Spectra of Polycyclic Aromatic Hydrocarbon 247 (aromatic region) 191

gHMQC spectra of Polycyclic Aromatic Hydrocarbon 247

NOESY spectra of Polycyclic Aromatic Hydrocarbon 247

${ }^{1}$ D TOCSY Spectra of Polycyclic Aromatic Hydrocarbon 247 (aromatic region) 194

DPFGSE NOE spectra of Polycyclic Aromatic Hydrocarbon 247 (aliphatic region) 195

DPFGSE NOE spectra of Polycyclic Aromatic Hydrocarbon 247 (aromatic region) 196

DEPT spectra of Polycyclic Aromatic Hydrocarbon 247

${ }^{1}$ D TOCSY Spectrum of Polycyclic Aromatic Hydrocarbon 240198

DPFGSE NOE spectrum of Polycyclic Aromatic Hydrocarbon 240199

${ }^{1} \mathrm{H}$ and ${ }^{13} \mathrm{C}$ NMR Spectra of Dimethoxy diketone $250 \quad 200-201$

${ }^{1} \mathrm{H}$ and ${ }^{13} \mathrm{C}$ NMR Spectra of Dibromoketone 252

${ }^{1} \mathrm{H}$ and ${ }^{13} \mathrm{C}$ NMR Spectra of Diketone $253 \quad$ 204-205

${ }^{1} \mathrm{H}$ and ${ }^{13} \mathrm{C}$ NMR Spectra of Diiododiketone $254 \quad$ 206-207

${ }^{1} \mathrm{H}$ and ${ }^{13} \mathrm{C}$ NMR Spectra of 2-(Indan-2-yl)-1,3-indandione $259 \quad$ 208-209

${ }^{1} \mathrm{H}$ and ${ }^{13} \mathrm{C}$ NMR Spectra of 2-Methyl-2-(indan-2-yl)-1,3-indandione $260 \quad$ 210-211

${ }^{1} \mathrm{H}$ and ${ }^{13} \mathrm{C}$ NMR Spectra of Propargylic diols $261 \quad 212-213$

${ }^{1} \mathrm{H}$ and ${ }^{13} \mathrm{C}$ NMR Spectra of Indanyldiketone 262 


\section{Part I}

\section{Cyclization Reactions of Enyne-Allenes}

\section{Introduction}

A touring scientist collected a rock at Waco, Texas and brought it to his laboratory to find fungi or bacteria living inside in 1987. He discovered a compound inside this rock, called calicheamicin (1) which is normally derived from organism, Micromonospora echinospora ssp calichensis and was proved to be over 1000 times more potent than adriamycin, an old chemotherapy drug. ${ }^{1}$ However, it is too toxic to be used directly as a medicine, although calicheamicin is extremely active against tumor and cancel cells, which can bind to DNA, cleave it into pieces, and finally cause cell death.

\subsection{Structure of enediynes}

The molecular architecture of calicheamicin (1) had aroused a great deal of interest due to its unique enediyne structure and intricate modes of action as well as exceptional antitumor and antibiotic activity. ${ }^{2}$

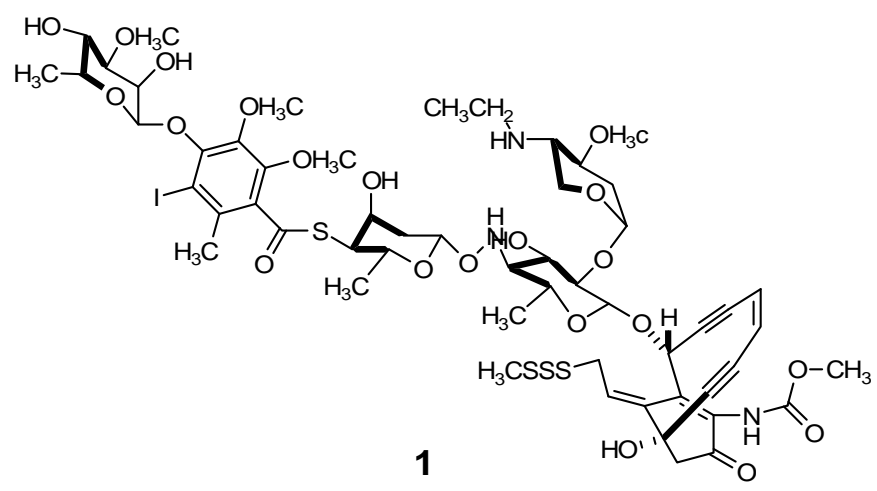

Figure 1. Structure of calicheamicin.

Their enediyne structures, characterized by two acetylenic groups conjugated to a double bond, fall into two categories: nine- or ten-membered ring core structure. ${ }^{3}$ 


\subsubsection{Endiynes with a 9-membered ring core structure}

Actually, the first elucidated structure of enediyne came from neocarzinostatin(NCS) chromophore which contains a nine-membered ring core, bicycle[7.3.0] structure. ${ }^{4}$ There had been a rapid escalation in the discovery of biologically active natural products containing enediyne: neocarzinostatin(NCS), ${ }^{5-7} \mathrm{C}-1027,{ }^{8}$ maduropeptin, ${ }^{9}$ N1999A2, ${ }^{10}$ actinoxanthin, ${ }^{11}$ largomycin, ${ }^{12}$ auromomycin, ${ }^{13}$ and sporamycin. ${ }^{14}$

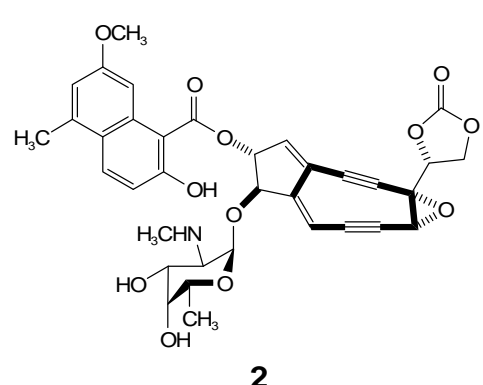

2

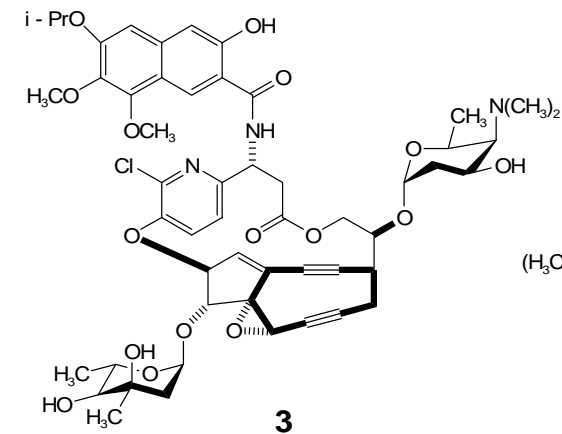

3

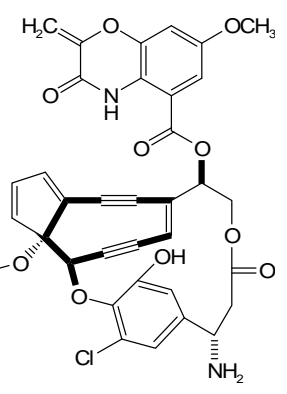

4
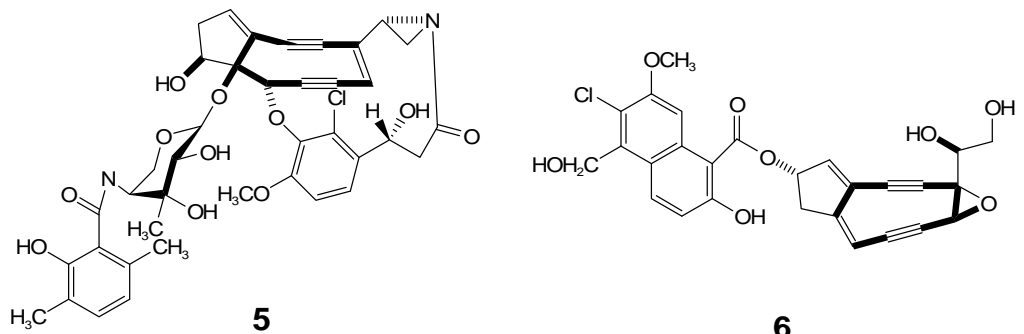

6

2. neocarzinostatin(NCS), 3. kedarcidin, 4. C1027, 5. maduropeptin, 6. N1999A2

Figure 2. Structures of enediynes containing a nine-membered ring core.

The relatively unstable nine-membered enediynes appear to be the most potent anticancel agents ever discovered, which is caused by the cyclization of the enediyne group via highly reactive 1,4-biradical intermediate triggering single- and double-stranded DNA lesion. ${ }^{15}$ The key transformation of the natural enediyne system into a diradical benzenoid species is based on the Bergman cycloaromatization, reported in the early 70th by Masamune and Bergman. ${ }^{16}$ Although the classical Bergman thermal cycloaromatization occurs only above $200{ }^{\circ} \mathrm{C}$, the steric strain due to the inclusion of enediyne in a nine-membered ring may 
decrease the activation energy to allow cyclization to occur at $37{ }^{\circ} \mathrm{C}$. ${ }^{17}$ The proposed mechanism shown in Scheme 1 is that stereospecific nucleophilic attack at C12 of the NCS chromopore 7 triggers the rearrangement of the ring skeleton, followed by the ring opening of the epoxide and the formation of cumulene $\mathbf{8}$, a very strained intermediate due to its rigidity, which then generates biradical 9 through rapid cycloaromatization. ${ }^{18}$
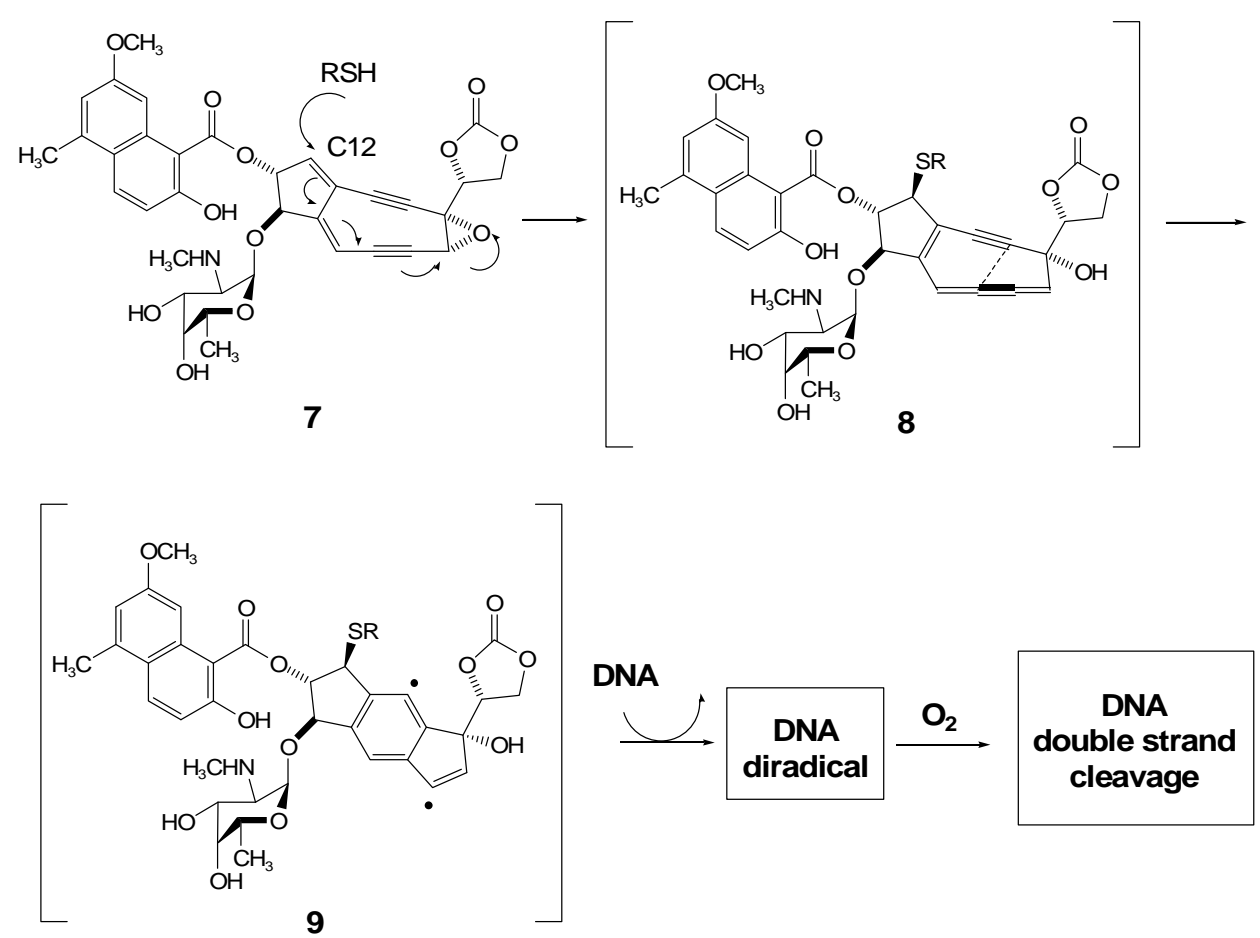

Scheme 1. Mechanism of action of neocarzinostatin chromophore containing a nine-membered ring core. ${ }^{19}$

\subsubsection{Endiynes with a ten-membered ring core structure}

Esperamicin containing an unprecedented ten-membered enediyne, was first discovered in 1985, which received much attention from a number of researchers, largely in the hope of finding new class of antitumor antibiotics. Most of naturally ocurring enediynes contain a more stable ten-membered ring and in rare cases contain a nine-membered ring. ${ }^{20}$ Esperamicin 11, namenamicin 10, and dynemicin 13 were previously reported and the most 
recent family member was shishijimicin 12 reported in $2003 .^{21}$ Although the mode of action of the ten-membered core is similar to that of the nine-membered enediyne, a relative unspecific mode of action causes side effects associated with its toxicity. ${ }^{21}$

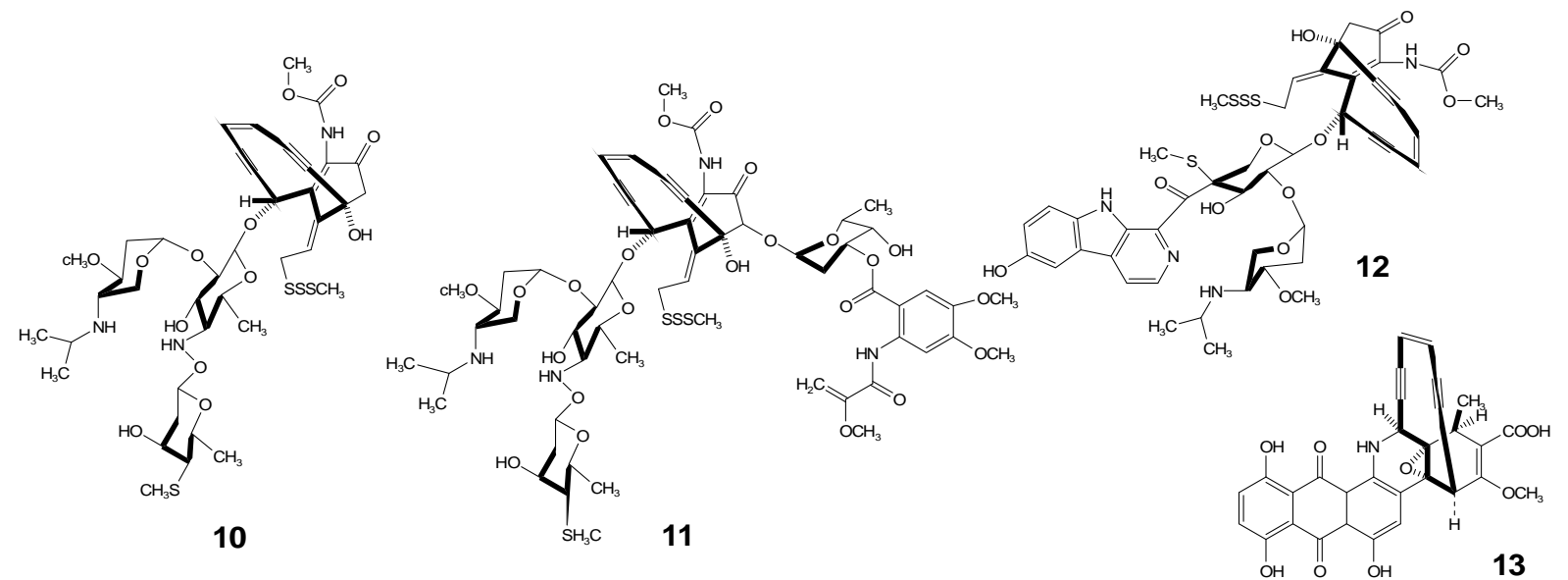

10. Namenamicin, 11. esperamicin, 12. shishijimicin, 13. dynemicin

Figure 3. Structures of enediynes containing a ten-membered ring core.

The proposed mechanism suggested that nucleophilic attack on the allyl trisulfide group of 14 cleaves the S-S bond and forms a new S-S bond, a thiolate 15, followed by cycloaromatization and biradical formation. ${ }^{22}$
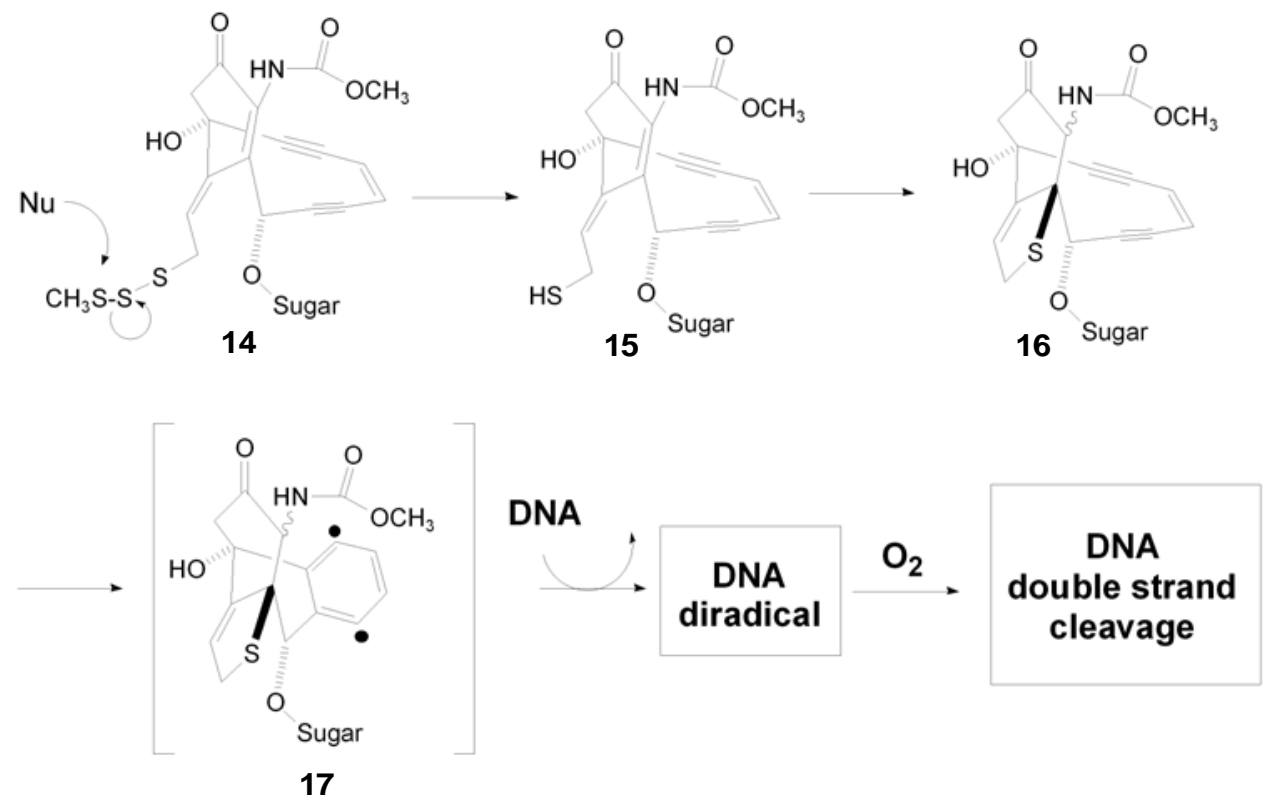

Scheme 2. Mechanism of action of shishijimicin containing a ten-membered core. ${ }^{3}$ 


\subsection{Research orientation to enediynes}

Initial main focuses on enediynes were total synthesis of the naturally occurring endiynes and simple model compounds bearing an endiyne structure, with similar antitumor and antibiotic activities. The relation between biradical cycloaromatization protocols and radical cyclizations has also been extensively studied. ${ }^{23}$ Organic chemists have explored the thermal cycloaromatization of enyne-allenes by $C^{2}-C^{7}$ (Myers-Saito) cyclization or $C^{2}-C^{6}$ (Schmittel) cyclization to furnish polycyclic aromatic systems. In addition, theoretical organic chemists have studied extensively the energetics of many modes of cyclization to demonstrate details on newly formed rings. ${ }^{24}$

\subsection{Bergman cyclization of the enediyne system}

Generally, Sondheimer et al. is regarded as the first group to synthesize the cyclization product related to enediyne chemistry in 1966. The proposed mechanism of this cyclization is that the 11-membered ring of the bicyclic hydrocarbon $\mathbf{1 8}$ could generate a fused ring system by transferring hydride ion from methoxide under reflux in dimethyl sulfoxide and with potassium hydroxide in methanol. ${ }^{25}$

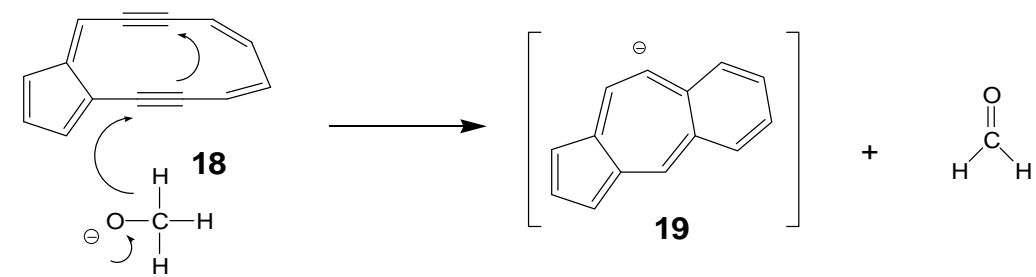

Scheme 3. Cyclization reported by Sondheimer.

A similar reaction was attempted by Masamune in 1971 who accidentally obtained anthracene (22) from diacetylene compound 20, although Bergman firstly reported his detailed mechanism on the cycloaromatization of enediynes. Masamune supposed the intermediate 
might be compound 21, but did not provide any proper mechanism regarding the unexpected cyclization. $^{26}$

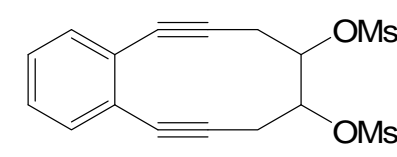

20

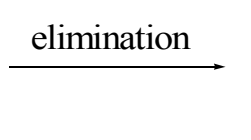

Scheme 4. Observed cyclization by Masamune.

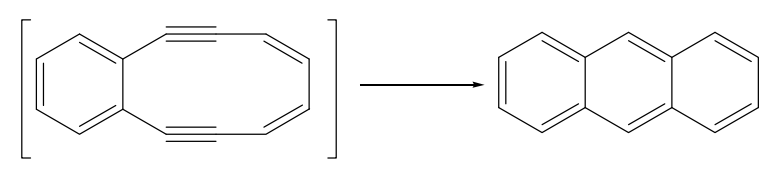

22

In 1972, Bergman formulated the cycloaromatization of enediynes by heating deuterium labeled cis-3-hexene-1,5-diyne (23a) at $200{ }^{\circ} \mathrm{C}$. After $5 \mathrm{~min}$, NMR showed deuteriums evenly distributed among acetylenic and vinyl positions (23a and 23c). He inferred that the free radicals of 1,4-dehydrobenzene $\mathbf{2 3 \mathbf { b }}$ are the only intermediate capable of removing hydrogens from hydrocarbon.

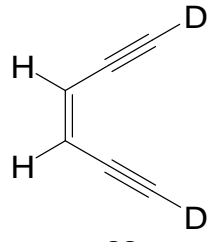

23a

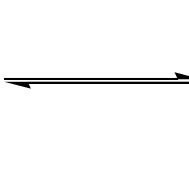

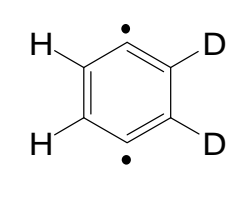

23b

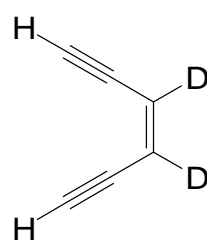

23c

Scheme 5. Thermal rearrangements of cis-3-hexene-1,5-diyne via 1,4-dehydrobenzene.

However, this labeling study with NMR did not provide any information regarding an intermediate or transition state. In order to confirm his inference, he pyrolyzed cis-3-hexene-1,5-diyne (24) in carbon tetrachloride, which generated $p$-dichlorobenzene. The observed products through this reaction were benzene, $p$-dichlorobenzene, and benzyl alcohol depending on the solvents used. This pioneering work of Bergman on enediyne cyclization had not gain much attention until the structures of calicheamicin and esperamicin, two potent antitumor anitibiotics, were elucidated. Bergman then reported that their enediyne system could trigger biradical aromatization responsible for DNA cleavage. These two novel substances containing an enediyne structure prompted organic chemists to synthesize unique 
unsaturated structures which could be cyclized. $^{27}$

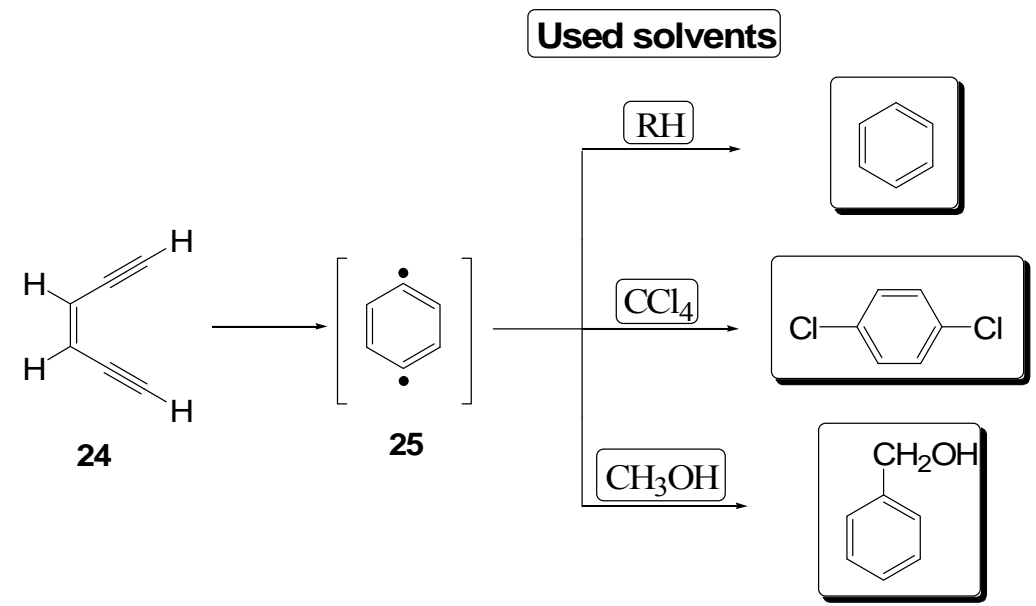

Scheme 6. Confirmation of biradical intermediate.

\subsection{Various cyclizations: Moore Cyclization, Myers Cyclization, Schmittel}

\section{Cyclization, and Myers-Saito Cyclization}
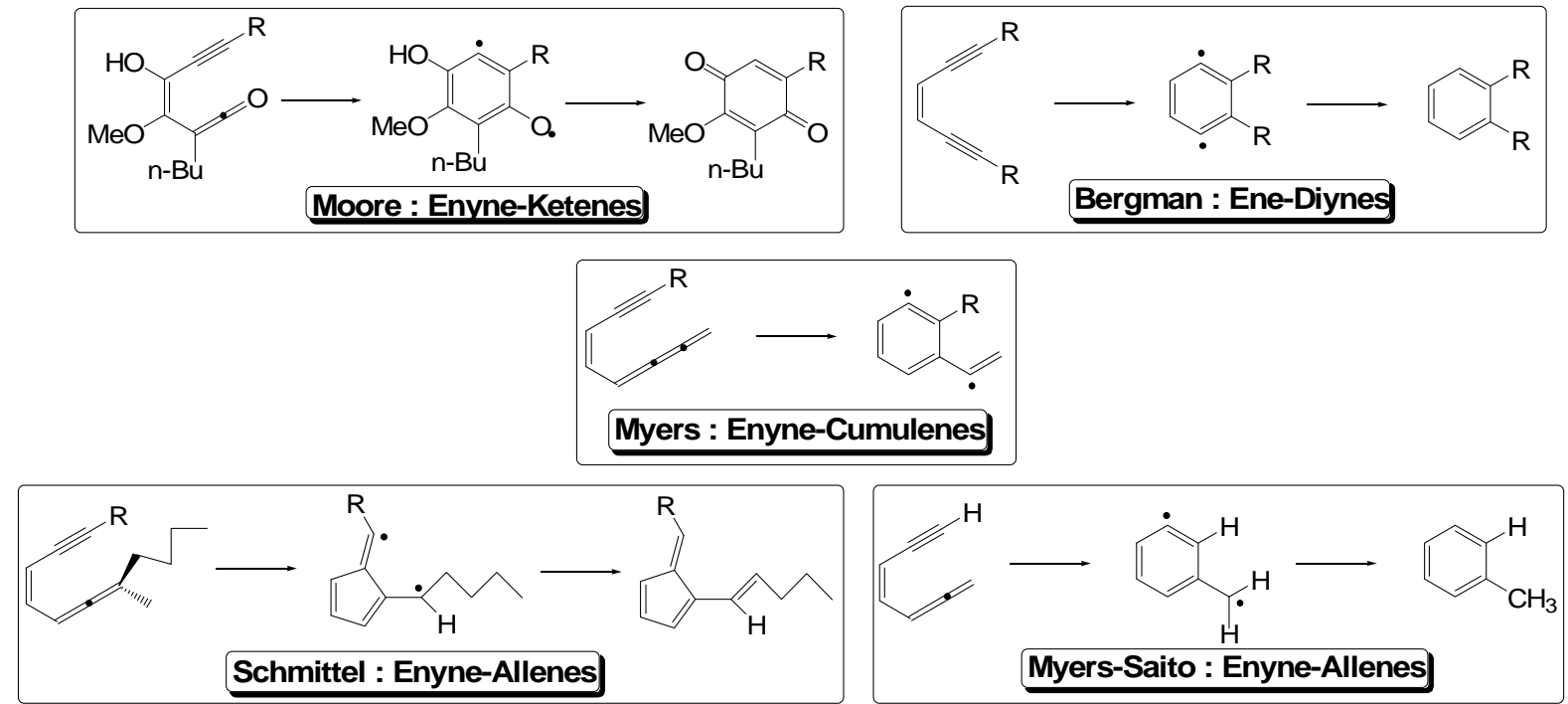

Figure 4. Moore $^{29}$ : Enyne-Ketenes, Bergman ${ }^{30}$ : Ene-Diynes, Myers ${ }^{31}$ : Enyne-Cumulenes, Myers-Saito ${ }^{32}$ : Enyne-Allenes, and Schmittel ${ }^{33}$ : Enyne-Allenes. ${ }^{28}$

\subsubsection{Moore Cyclization: Enyne-Ketenes}


The Moore cyclization of enyne-ketenes is also a type of biradical cyclization reactions such as Bergman reaction of enediynes. Before the remarkable discovery of Myers-Saito cyclization, Moore had already found a similar cyclization mode from enyne-ketenes. However, the Moore cyclization did not receive as much attention as the Bergman or Myers-Saito cyclization because it did not show antitumor antibiotic activities as those of enediynes and enyne-allenes. ${ }^{28}$ Moore et al. reported the $\mathrm{C}^{2}-\mathrm{C}^{7}$ and the $\mathrm{C}^{2}-\mathrm{C}^{6}$ cyclizations of enyne-ketens giving rise to quinones 29,30 or cyclopentenedione 32 , and their derivatives. 4-Alkynylcyclobutenones 26 and 27 generated the ketene 28 via ring opening under thermolysis, which then underwent ring closure with an intramolecular transfer of the substituent E (proton, trimethylsilyl, or allyl) from oxygen to carbon. ${ }^{34}$ Surprisingly, he suggested that the phenyl group of the alkynyl moiety might redirect the cyclization reaction toward the formation of a 5-membered ring, since the phenyl group or the alkynyl group might be able to stabilize the adjacent radical ion on $\mathrm{C} 7$.

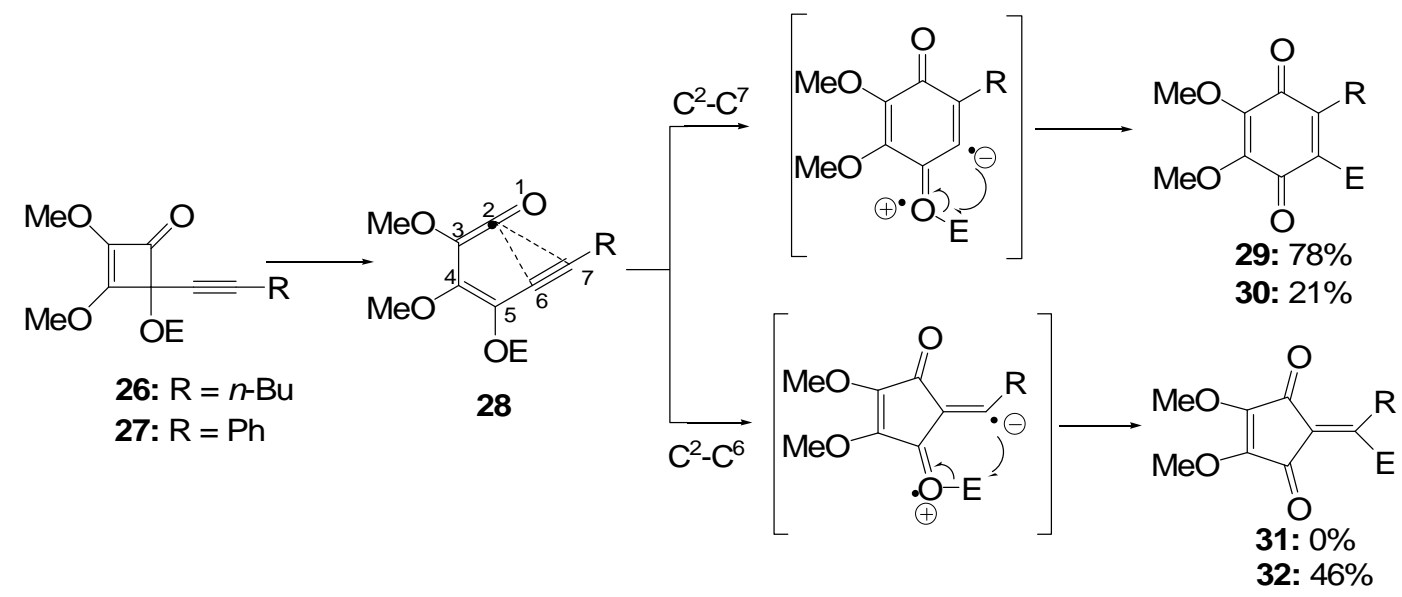

Scheme 7. Moore cyclization; $C^{2}-C^{7}$ and $C^{2}-C^{6}$ cyclizations of enyne-ketenes.

\subsubsection{Myers-Saito $\left(C^{2}-C^{7}\right)$ Cyclization: Enyne-Allenes}

In 1989, Myers and Saito groups reported independently that enyne-allene system containing 1,2,4-heptatrien-6-yne (33) underwent thermal cyclization reaction via biradical formation. 


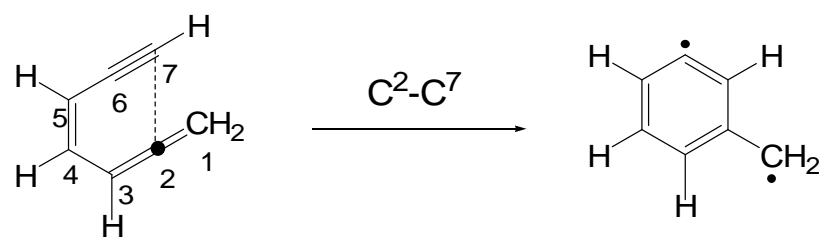

33

Scheme 8. Myers-Saito Cyclization: $C^{2}-C^{7}$ cyclization of enyne-allene.

At that time, mechanistic studies of the antitumor agents, neocarzinostatin, calicheamicin, and esperamicin were ongoing to identify essential features triggering their antibiotic activities. It was a generally accepted idea that the cyclic endiyne system abstracts hydrogen atoms from the DNA backbone via reactive benzenoid biradicals. This proposal prompted many groups to participate in the design of a simplified endiyne system to mimic the mode of action of the antitumor agents. ${ }^{35}$ Myers group provided supporting evidence that the cyclization reaction occurs via biradical intermediate by using various solvent systems as summarized in Scheme 9. ${ }^{36}$ Saito et al. and Myers et al. reported that the enyne-allene system could produce a biradical at lower temperature than that of the Bergman cyclization reaction. The Arrhenius activation barrier of the enyne-allene system was measured to be 21-23 $\mathrm{kcal} / \mathrm{mol}$ lower than that of the enediyne system. ${ }^{37}$

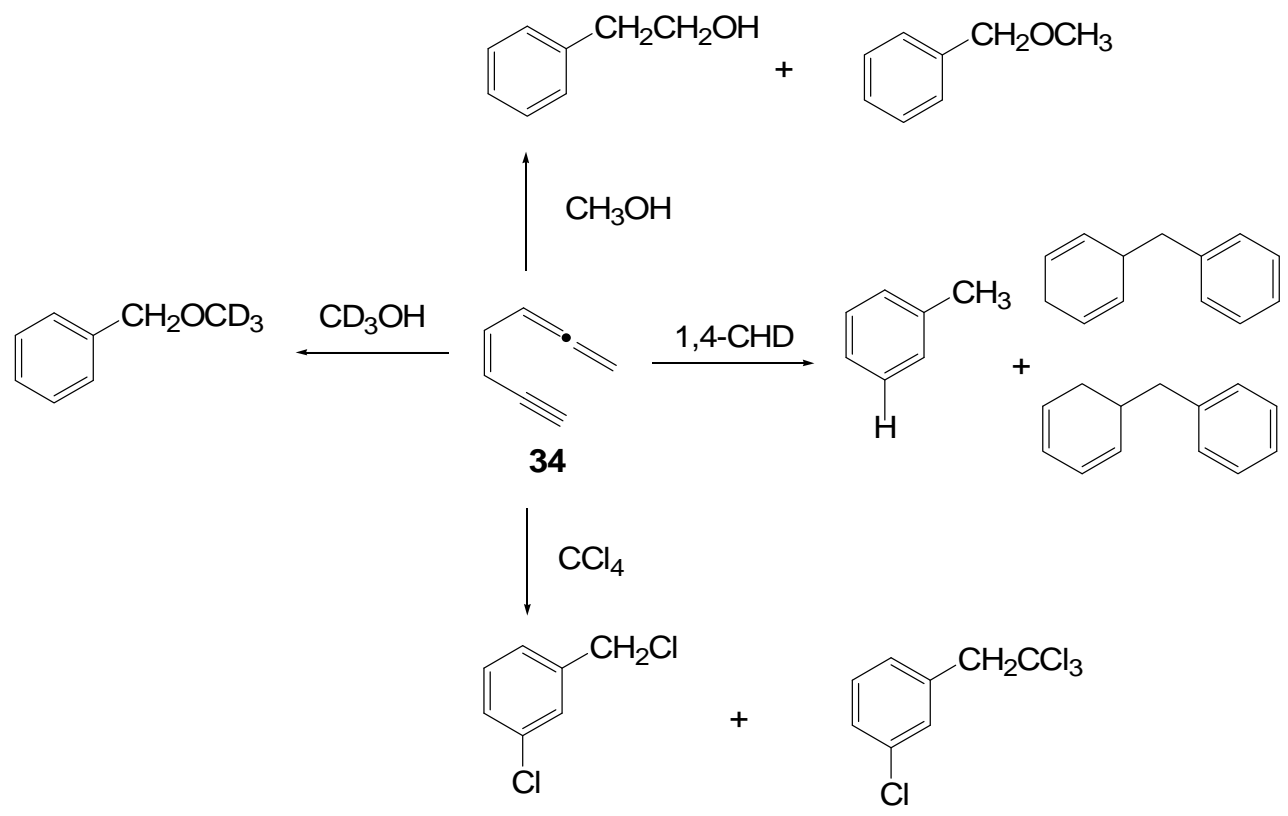

Scheme 9. Evidence of cyclization reaction via biradical intermediate. 
Saito group postulated the distance between C1 and C6 for enyne-allene cyclization is close enough to trigger spontaneous cyclization at lower temperature than that of the Bergman cyclization which occurs at more than $130{ }^{\circ} \mathrm{C} .{ }^{35 a}$ They designed a simple enyne-allenyl phosphonate $\mathbf{3 6}$ to demonstrate the cyclization generates a biradical intermediate capable of DNA cleavage activity at ambient temperature.

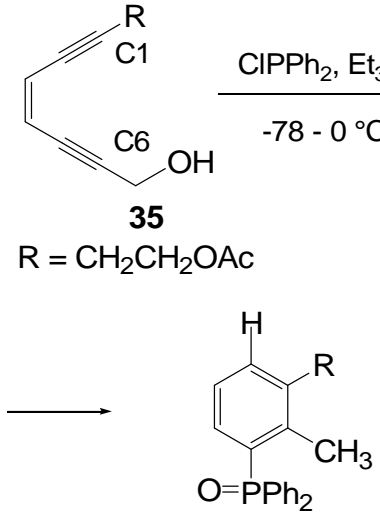

37: $32 \%$

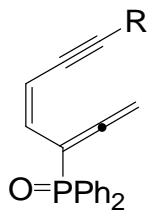

36

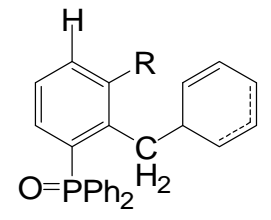

38: $17 \%$
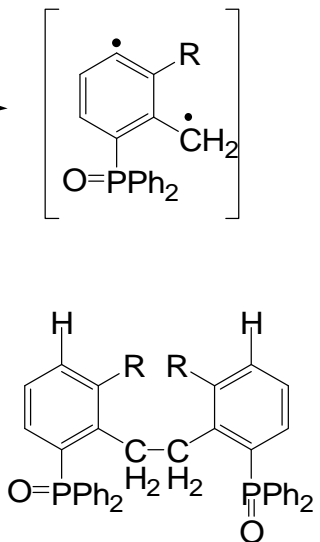

39: $8 \%$

Scheme 10. Saito group's approach for cyclization of enyne-allene.

\subsubsection{Schmittel $\left(C^{2}-C^{6}\right)$ Cyclization: Enyne-Allenes}

In 1995, Schmittel and co-workers discovered a complete switch from Myers-Saito $\left(C^{2}-C^{7}\right)$ cyclization to Scmittel $\left(C^{2}-C^{6}\right)$ cyclization, which was a remarkable discovery further extending the synthetic potentials of thermal enyne-allene reactions. ${ }^{38}$ The Schmittel group unexpectedly discovered the novel $C^{2}-C^{6}$ cyclization by replacing the terminal hydrogen atom with an aryl group (40, $\mathrm{R}^{1}=p$-tol), which generated $41 \mathrm{~b}$ and $\mathbf{4 2 b}$ in the presence of 1,4-cyclohexadiene. They suggested that the aryl group could stabilize the formation of an adjacent vinyl radical in 41a and 41b, leading to either a formal Diels-Alder adduct or an ene product. 

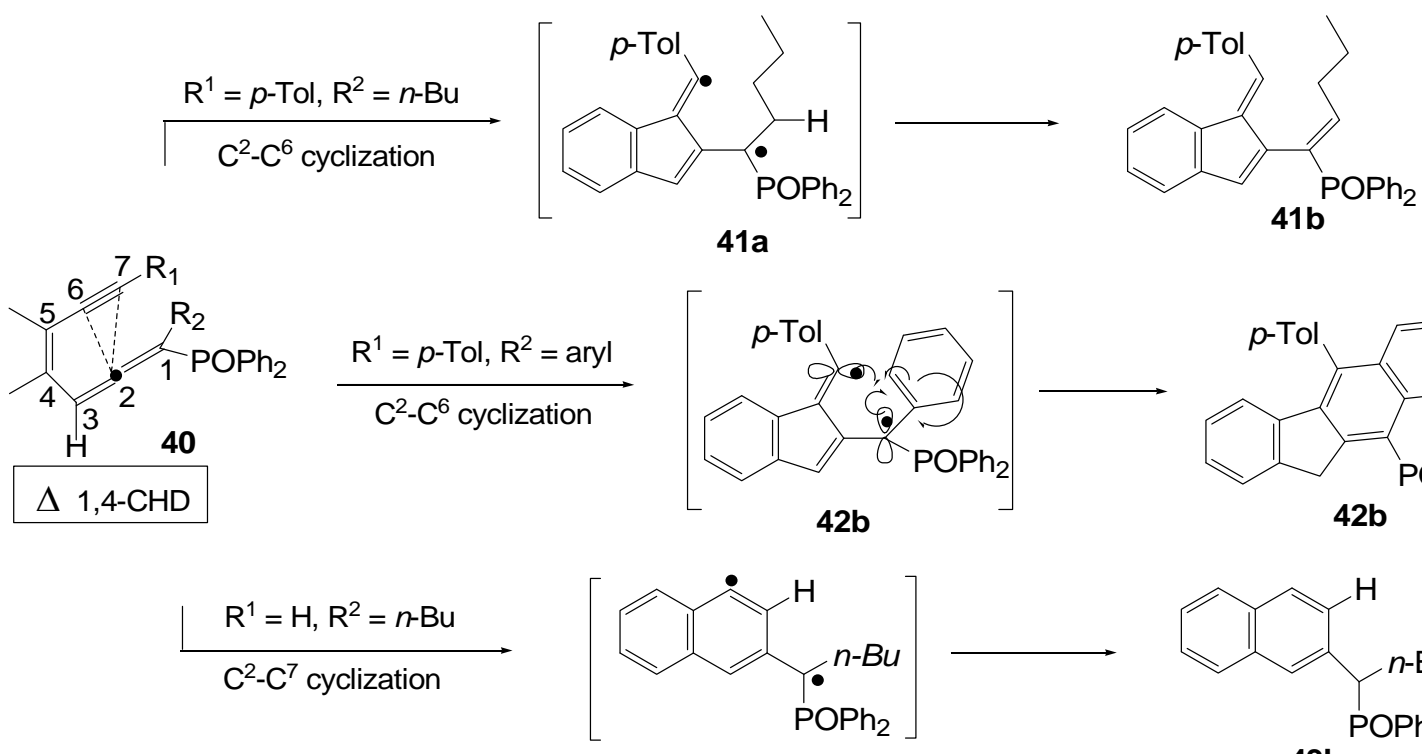

$43 a$
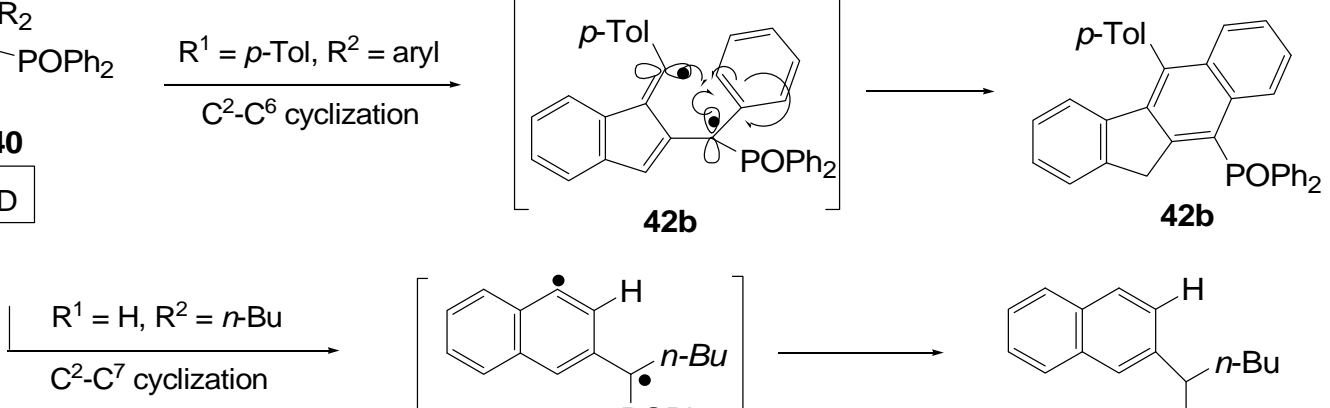

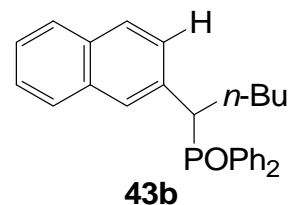

$43 b$

Scheme 11. Mechanism of switch from $C^{2}-C^{7}$ cyclization to $C^{2}-C^{6}$ cyclization.

\subsubsection{Various effects on Myers-Saito $\left(C^{2}-C^{7}\right)$ and Schmittel $\left(C^{2}-C^{6}\right)$ cyclization}

Since Gillman et al. ${ }^{39}$ and Rodriguez et al. ${ }^{40}$ discovered a similar new $\mathrm{C}^{2}-\mathrm{C}^{6}$ reaction by placing the sterically bulky TMS group at acetylenic terminus, various effects for switching from Myers-Saito to Schmittel cyclization have been elucidated. This switch is attributed to substituent effects of aryl substutuents on the acetylene terminus, ring strain caused by ring size, benzannulation and oxy-anion substitution, and steric effects exerted by bulky substituents especially at the alkyne terminus or on the allene. ${ }^{41}$

The ring strain generated by cyclopentene ring resulted in the switch from the $\mathrm{C}^{2}-\mathrm{C}^{6}$ cyclization to $C^{2}-C^{7}$ cyclization despite the presence of a phenyl substituent (44) at the alkyne terminus. ${ }^{42}$
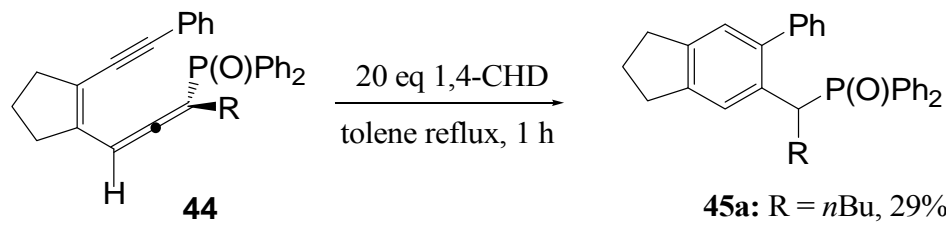

45a: $\mathrm{R}=n \mathrm{Bu}, 29 \%$

46b: $\mathrm{R}=\mathrm{Ph}, 38 \%$

Scheme 12. Thermolysis of enyne-allenes with a central five-membered ring. 
Surprisingly, this phenomenon had already been observed in our group without mentioning the ring strain effect generated by the five-membered ring. ${ }^{43}$

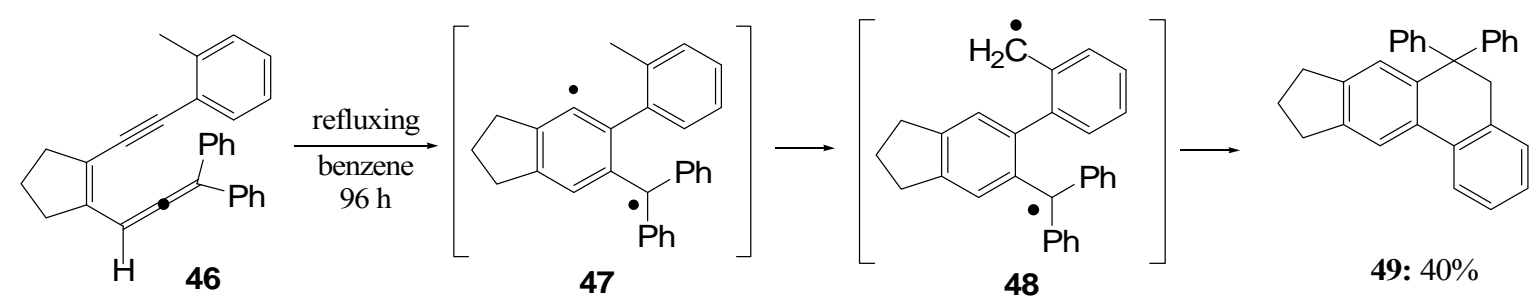

Scheme 13. $C^{2}-C^{7}$ cyclization generated by ring strain.

Scheme14 below shows that a bulky group (50) at the alkyne terminus destabilized the $\mathrm{C}^{2}-\mathrm{C}^{7}$ transition state due to steric congestion between the bulky group and newly formed benzene ring. Simply changing $H$ to the methyl group at the inner position of allene (52a and $\mathbf{5 2 b}$ ) destabilizes the resulting enyne-allene. The eneyne-allene product $\mathbf{5 3 b}$ is not stable at room temperature, undergoing thermal $\mathrm{C}^{2}-\mathrm{C}^{6}$ cyclization directly to produce $54 .^{43}$

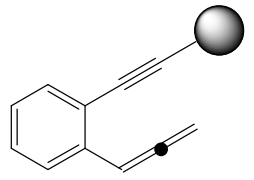

50

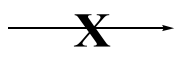<smiles>[X]C(C#C[Hg]c1ccccc1)(OC(C)=O)c1ccccc1C#C[SnH]</smiles>

52a: $X=\mathrm{H}$ 52b: $X=\mathrm{Me}$<smiles>Cc1cc2ccccc2cc1O</smiles>

51
$\mathrm{O}=$ bulky group

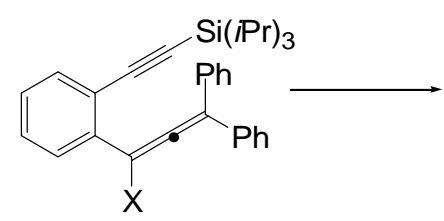

53a: $\mathrm{X}=\mathrm{H}, 67 \%$ 53b: $X=M e$, not isolable

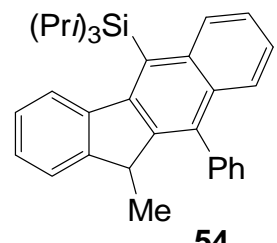

54

Scheme 14. $C^{2}-C^{7}$ and $C^{2}-C^{6}$ cyclization affected by substituents.

Brunette and Lipton investigated the electronic role of the oxyanion substituent. The substitution led to rapid cyclization at ambient temperature or even subambient temperatures. ${ }^{44}$ The acceleration of the $C^{2}-C^{6}$ cyclization by oxyanion was presumed to arise from the stabilization of biradicaloid transition state which has the same origin as the well known 
acceleration of the Oxy-Cope rearrangement. ${ }^{45}$

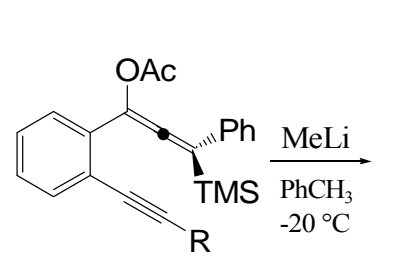

55a: $R=$ TMS

55b: $\mathrm{R}=t-\mathrm{Bu}$

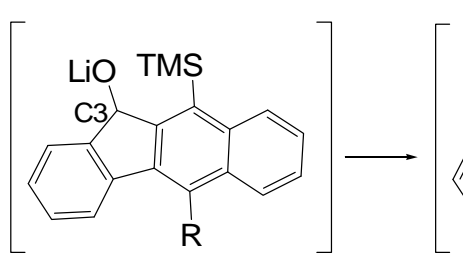

56

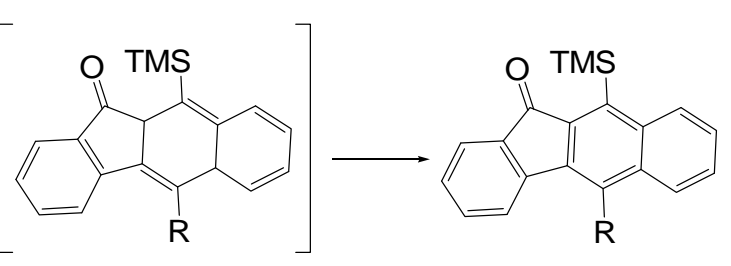

57 58a: $44 \%$ 58b: 50\%

Scheme 15. Acceleration of cyclization by oxyanion substituent.

\subsubsection{Heteroaromatic compounds via $C^{2}-C^{6}$ cyclization}

Interestingly, our group and Schmittel's group reported the biradical forming reactions involving other heteroatoms in 1998, which was an unexplored area at that time, by substituting a carbon with a nitrogen or an oxygen on the enyne-allene frameworks. ${ }^{46}$ Valuable heteroaromatic compounds which are potential DNA-intercalating agents have been synthesized in our group by converting carbons (A, B, C, D, and E) to nitrogens or by placing a variety of heteroatom-containing substituents at the allenic terminus. The first heterocyclic system was synthesized from enyne-ketenimines ( $\mathrm{B}=$ nitrogen, $\mathrm{C}=$ carbon $),{ }^{46}$ enyne-carbodiimides $(\mathrm{B}=$ nitrogen, $\mathrm{C}=$ nitrogen $),{ }^{47}$ and enyne-isocyanates $\quad(\mathrm{B}=$ oxygen, $\mathrm{C}=$ nitrogen $)^{48}$ via biradical intermediates $\mathbf{6 0}$. The substitution of the alkynyl group with the isoelectronic nitrile group $(\mathrm{D}=\text { nitrogen, } E=\text { carbon })^{49}$ or the nitrile group $(D=$ carbon, $\mathrm{E}=$ nitrogen $)^{50}$ produced the corresponding $11 H$ indeno[1,2- $\left.b\right]$ quinoline-related compounds and substituted ABCD ring cores of the camptothecin family of alkaloids, respectively.

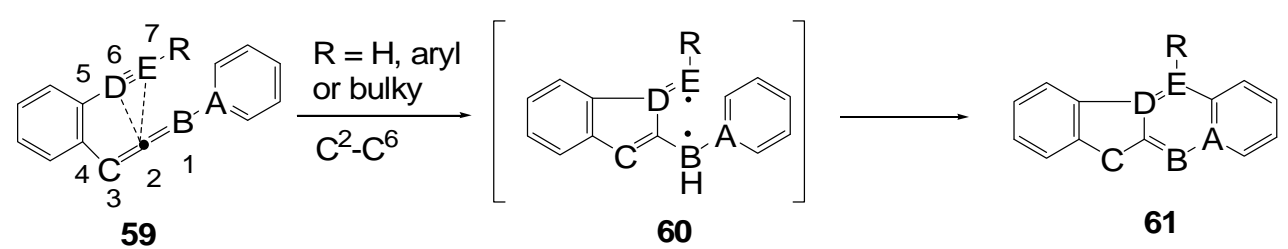

Scheme 16. Heteroaromatic compounds via $C^{2}-C^{6}$ cyclization. 


\subsubsection{The concerted or the biradical mechanism of the enyne-allene reaction}

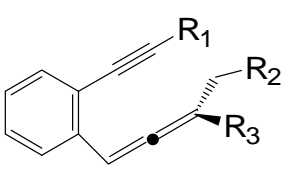

62

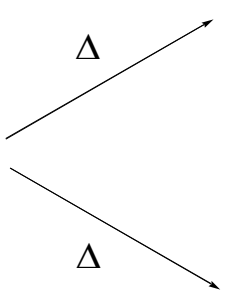

$\Delta$

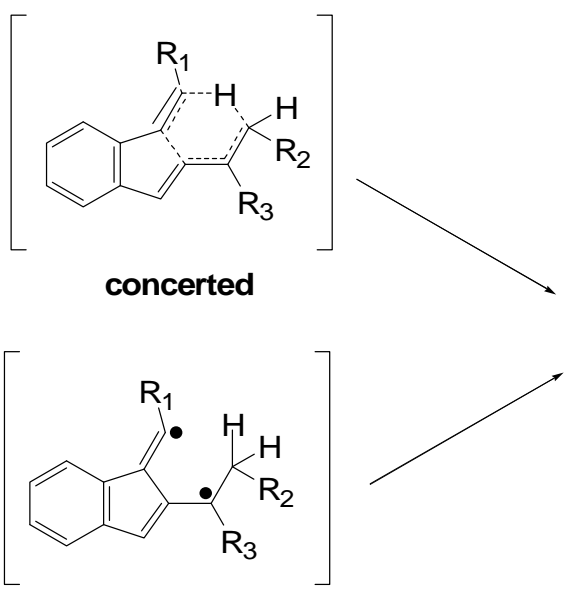

biradical

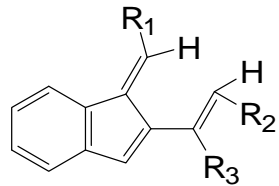

63

Scheme 17. The concerted or the biradical mechanism of the enyne-allene reaction.

Although the postulated formation of biradical intermediate in the naturally occurring endiyne and enyne-cumulene antitumor antibiotics had been proposed, examples in many literatures could be reconciled with concerted ene or Diels-Alder reaction. Most of the mechanistic and theoretical evidences are in favor of the stepwise biradical intermediate of the $\mathrm{C}^{2}-\mathrm{C}^{6}$ thermal cycloaromatization, supporting a fulvenyl biradical mechanism. ${ }^{51}$ Most convincing and direct result for the postulated stepwise biradical intermediate of $\mathrm{C}^{2}-\mathrm{C}^{6}$ cyclization is that the fulvene biradical intermediate could be trapped by hydrogen atom transfer. When enyne-allene $\mathbf{6 4}$ was heated for $18 \mathrm{~h}$ in 1,4-cyclohexadiene, the benzofulvene derivatives, $7 \%$ of $(Z)-65$ and $4 \%$ of $(\boldsymbol{E})-\mathbf{6 5}$ were obtained along with $3 \%$ of the $C^{2}-C^{7}$ product 66.5

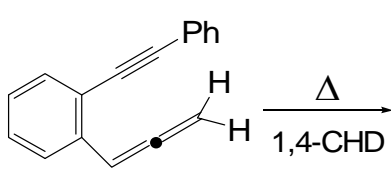

64<smiles>CC1=Cc2ccccc2C1=Cc1ccccc1</smiles>

(Z)-65: 7\%<smiles>CC1=Cc2ccccc2/C1=C/c1ccccc1</smiles>

(E)-65: 4\%<smiles>Cc1cc2ccccc2cc1-c1ccccc1</smiles>

66: $3 \%$

Scheme 18. Evidence of the biradical intermediate, benzofulvene of the $C^{2}-C^{6}$ cyclization.

Another significant evidence for a stepwise mechanism was supported by the 
activation barriers of the formation $\mathbf{6 9}$ which would be expected to require much higher energy than that of $\mathbf{6 8}$ because the sterically hindered bulky mesityl group slows down the rate of cyclization reaction. However, the activation energy of 68 and 69 from 67 are almost the same by $25.9 \mathrm{kcal} / \mathrm{mol}$ and $26.3 \mathrm{kcal} / \mathrm{mol}$, respectively. ${ }^{53}$
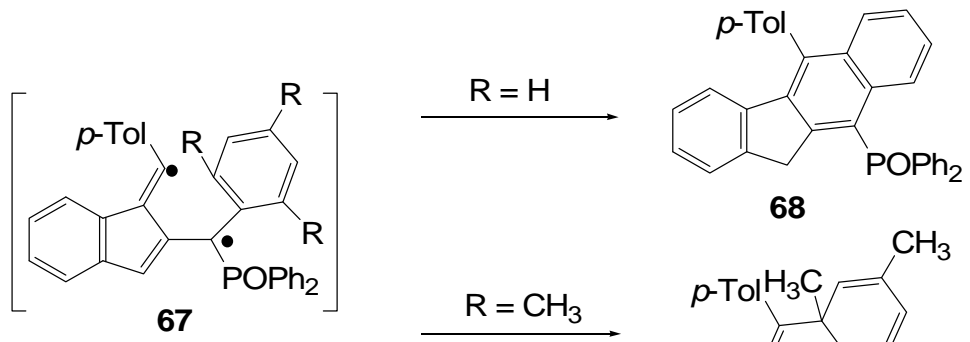

68

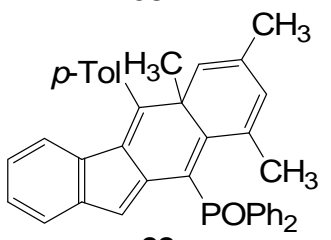

69

Scheme 19. Evidence for a stepwise mechanism: mesityl group doesn't affect activation energy.

Another evidence for this reaction is that the rate of the cyclization of enyne-allene system was not affected by the solvent change from nonpolar solvent (bezene) to polar solvent (DMSO) which excludes a zwitterionic intermediate. ${ }^{54 \mathrm{~b}}$ The experimental evidence of the kinetic isotope effects (KIE) also supported a stepwise biradical mechanism of enyne-allenes. $\mathrm{KIE}^{54}$ is a powerful method to observe the reaction rate change. When an atom in one of the reactants is replaced by one of its isotopes, significant reaction rate change could be observed at the bond-breaking or the bond-forming step. Larger than two of KIE $\left(=k_{H} / k_{D}\right)$ represents a hydrogen transfer is the rate determining step, which is taken as an evidence for concerted mechanism. On the basis of experimental data of $\mathrm{KIE}=1.17$, Schmittel concluded that the stepwise biradical mechanism is more predominant than the concerted ene reaction mechanism that Engels inferred through computational investigation. ${ }^{55}$

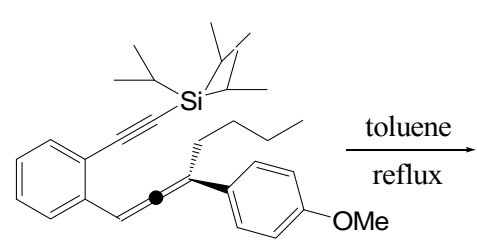

70

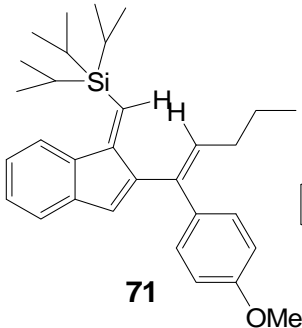

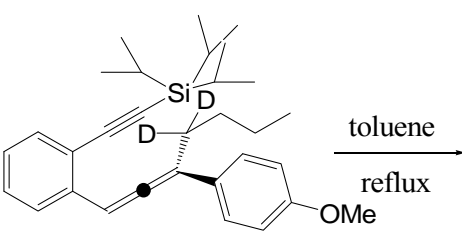

72

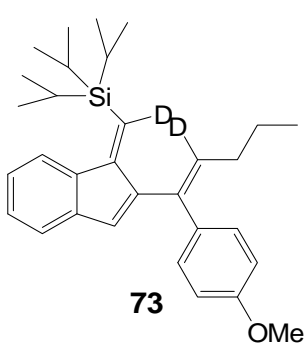

73 $\mathrm{OMe}$

Scheme 20. Kinetic isotope effect (KIE) experiment by Schmittel. 


\subsection{Literature survey on the preparation of enyne-allenes or enyne-cumulenes}

As mentioned earlier, the most widely used methodology for the synthesis of enyne-allenes was [2,3]-sigmatropic rearrangement of enediynyl propargylic alcohols 74, which was adopted by Saito, ${ }^{56}$ Nicolaou, ${ }^{57}$ Grissom $^{58}$ and Schmittel $^{59 a, c}$ for the synthesis of a variety of allenyl phosphonates or phosphine oxides.

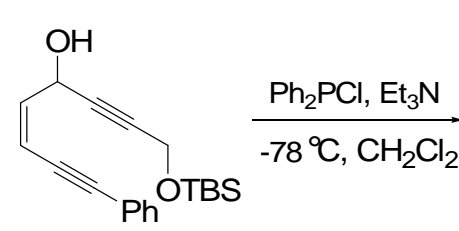

74

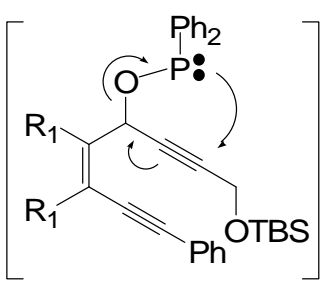

75

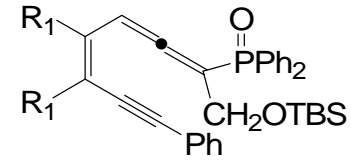

76

Scheme 21. Enyne-allenes via [2,3]-sigmatropic rearrangement of enediynyl propargylic alcohols.

First conjugated enyne-cumulene system was synthesized by Hirama group who expected cross-conjugated dienediyne $\mathbf{7 7}$ to undergo a vinylogous propargylic rearrangement. The dimethyl substituents on $\mathrm{C} 11$ prevented direct $\mathrm{S}_{\mathrm{N}} 2$ reaction and thermolysis of the desired vinylogous $S_{N} 2$ product 78 led to the Bergman type cyclization via biradical intermediate 79 and $\mathbf{8 0}$ in deoxygenated 1,4-cyclohexadiene at $80{ }^{\circ} \mathrm{C} .{ }^{60}$

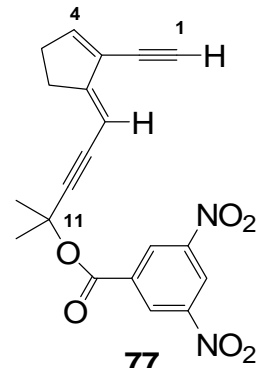

77

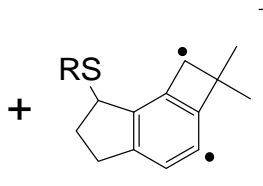

80
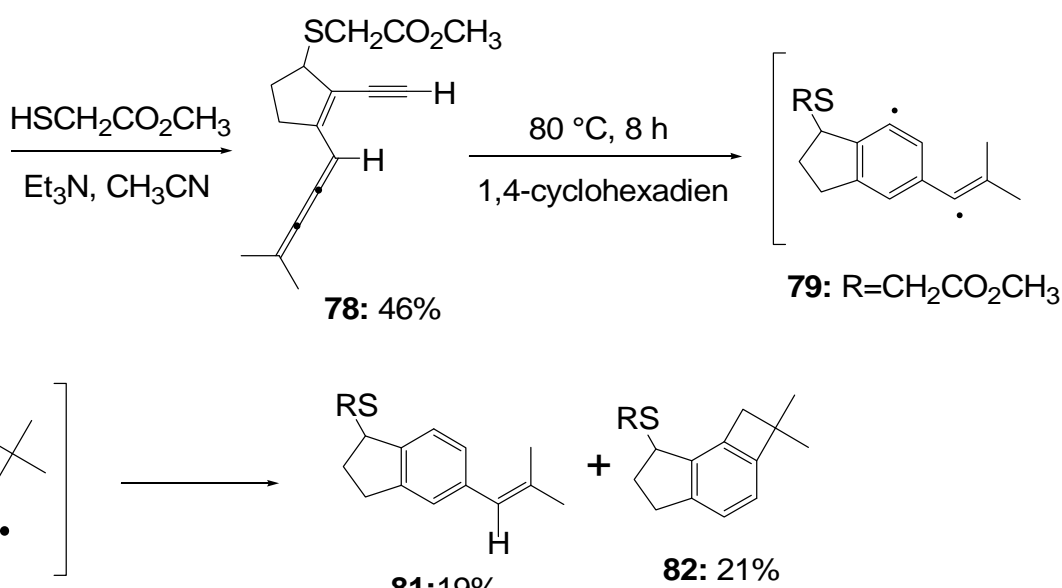

81:19\%
82: $21 \%$

Scheme 22. First conjugated enyne-cumulene system by the Hirama group. 
Transition-metal catalyzed coupling reactions have been employed for the synthesis of a variety of enyne-allenes. Gillman group ${ }^{61}$ synthesized an enyne-allene ester through the Pd-catalyzed coupling reaction between arylzinc halides 83 and 2-halo-allene carboxylates 84 at room temperature. Heating silyl derivative $\mathbf{8 5}$ in chlorobenzene in the presence of 1,4-cyclohexadiene produced the tricyclic product 86 through a [2+2] cycloaddition reaction. ${ }^{61}$

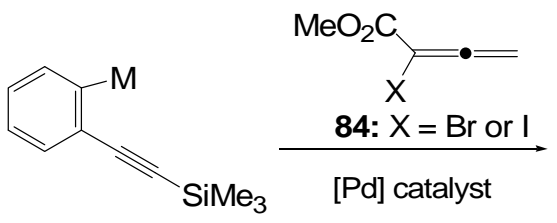

83a: $\mathrm{M}=\mathrm{ZnCl}$ 83b: $\mathrm{M}=\mathrm{B}\left(\mathrm{OCH}_{3}\right)_{2}$

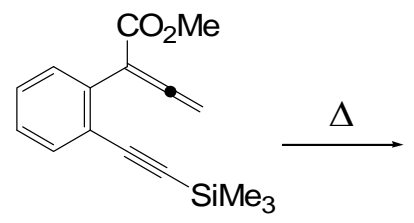

85: $40-42 \%$

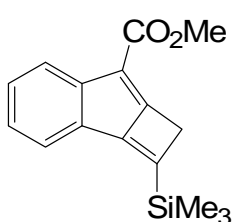

86: $62 \%$

Scheme 23. Enyne-allenes via transition metal-catalyzed coupling reactions.

Enyne-allene $\mathbf{8 8}$ could be easily prepared from $\mathbf{8 7}$ through a 1,3-prototropic rearrangement under basic conditions (Scheme 24). ${ }^{62}$ The enediyne-sulfone underwent base-catalyzed conversion to eneyne-allene-sulfone 88, which then underwent the Myers cyclization reaction leading to $\mathbf{9 0}$.

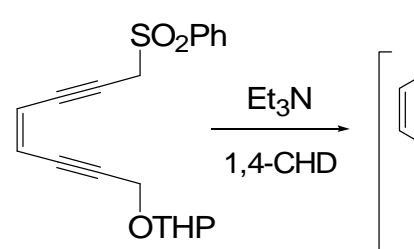

87<smiles>Cc1ccccc1CS(=O)(=O)c1ccccc1</smiles>

88

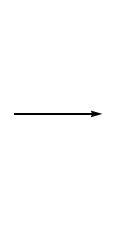

$\sqrt{2}$

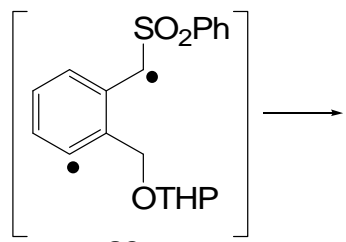

89

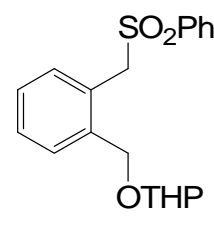

90:45\%

Scheme 24. Enyne-allene via prototropic rearrangement under a basic condition.

Enyne-allenes could also be prepared via double olefination using titanium-substituted ylides. This synthetic methodology was reported by the Finn group. ${ }^{63}$ The cycloaromatization rate and the product selectivity by changing the steric and electronic properties of the substituents $\mathrm{R}_{1}$ and $\mathrm{R}_{2}$ were investigated extensively. ${ }^{63}$ 


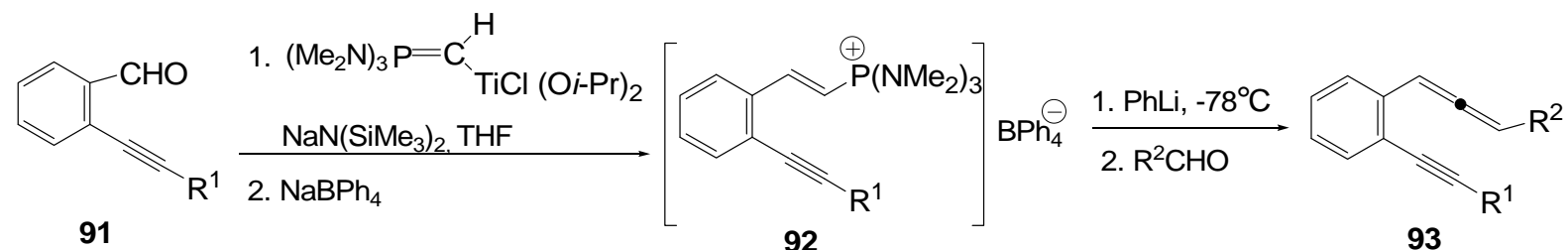

Scheme 25. Synthesis of benzannulated enyne-allenes 93 via titanium-substituted ylides.

Recently, the Toste group envisioned a mechanism involving sequential rearrangements by transition-metal activation of alkynes. The metal was coordinated to the acetylene adjacent to propargylic ester, which then generated enyne-allene 98 via a [3,3]-sigmatropic rearrangement. The remaining alkyne might also be activated by this metal, allowing the final Myers-Saito cyclization through the 6-endo-dig addition of the allenyl acetate. $^{64}$

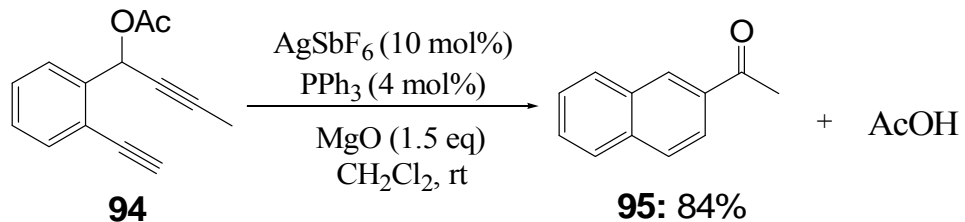

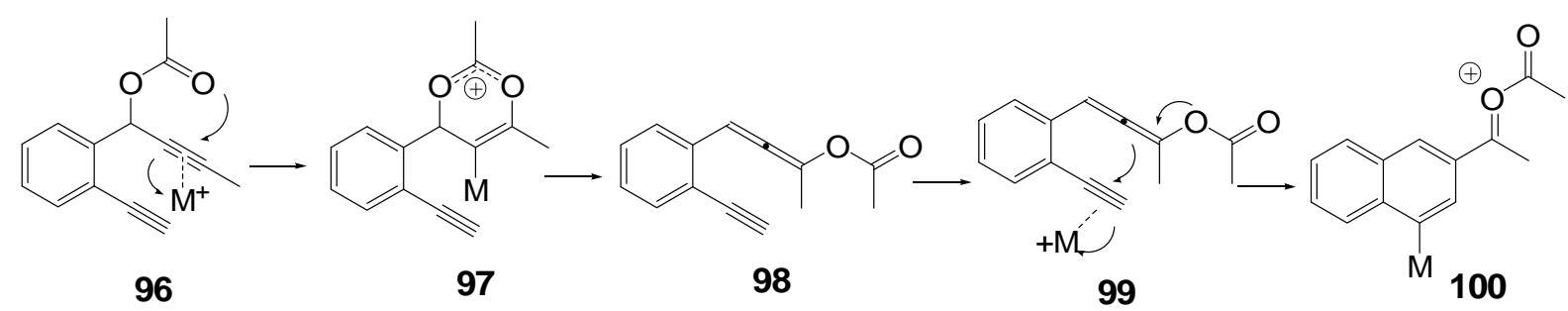

Scheme 26. Synthesis of the benzannulated enyne-allenes 98 via the metal-activated $[3,3]$-sigmatropic rearrangement. 


\section{Part II}

\section{Synthesis of Bowl-Shaped Polycyclic Aromatic Hydrocarbons via Palladium-Catalyzed Intramolecular Arylation Reactions}

\section{Introduction}

The synthesis of buckybowls, usually referred to as bowl-shaped polycyclic aromatic hydrocarbons on the surface of buckminsterfullerene, or fullerene fragments, has evoked intense research activity in recent years due to their useful applications for nanotechnology, electronics, optics, and other fields of materials science. Discoverers of fullerene $\mathrm{C}_{60}, \mathrm{H} . \mathrm{W}$. Kroto, R. F. Curl and R. E. Smalley, were awarded the Nobel prize in chemistry for the year 1996. ${ }^{65 a}$ Buckminsterfullerene, $C_{60}$ the smallest fullerene, is composed of twenty hexagonal rings and twelve pentagonal rings. The shape of the molecule prevents it from being planar. ${ }^{65 \mathrm{~b}}$

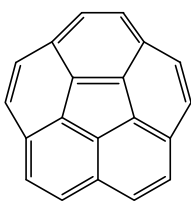

$\mathrm{C}_{20} \mathrm{H}_{10}$ Corannulene

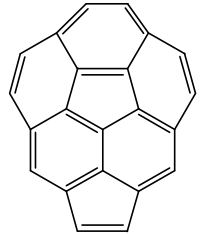

$\mathrm{C}_{22} \mathrm{H}_{10}$ Acecorannulene

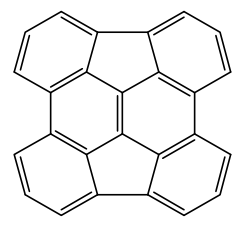

$\mathrm{C}_{26} \mathrm{H}_{12}$ Tetrabenzopyracylene

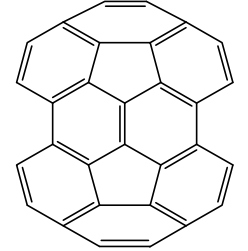

$\mathrm{C}_{30} \mathrm{H}_{12}$ $[5,5]$ Circulene

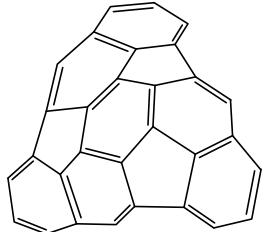

$\mathrm{C}_{30} \mathrm{H}_{12}$ Hemifullerene- $\mathrm{C}_{3}$

Figure 5. Various bowl-shaped polycyclic aromatic hydrocarbons.

Although fullerene $\mathrm{C}_{60}$ was discovered in 1985 , corannulene (102), the smallest bowl-shaped polycyclic aromatic hydrocarbon, was synthesized by Barth and Lawton in 1966. ${ }^{66}$ This pioneering synthesis of seventeen steps could not ignite extensive studies on bowl-shaped polycyclic aromatic hydrocarbons because of its lengthy synthetic pathway. 


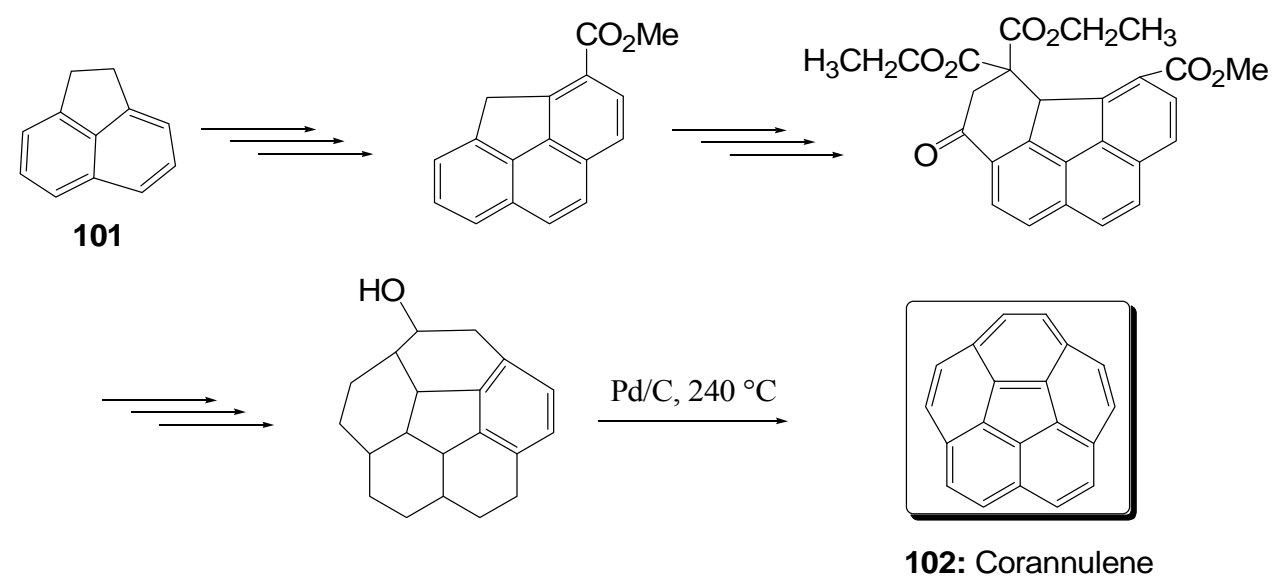

Scheme 27. Synthesis of Corannulene by Barth and Lawton.

However, this non-pyrolytic work for the synthesis of corannulene became a noteworthy landmark 30 years later, when Siiders and Siegel synthesized several curved molecules by a titanium-promoted reductive coupling strategy, followed by dehydrogenation of dimethyltetrahydrocorannulene with DDQ. ${ }^{67}$

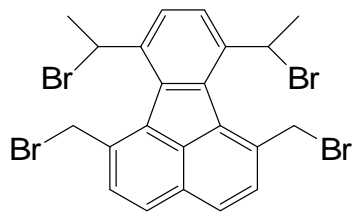

103

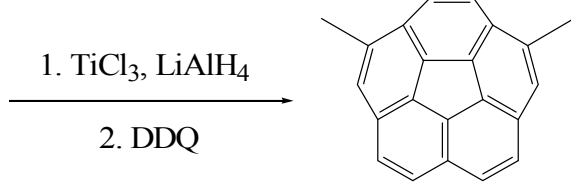

104

Scheme 28. Siiders and Siegel's approach for the synthesis of corannulene.

\section{Literature survey on the synthesis of bowl-shaped polycyclic aromatic hydrocarbons}

In 1991, Scott reported a short route to synthesize corannulene by using flash vacuum pyrolysis (FVP) from commercially available starting material, which opened a new era and inspired many groups to participate in this field. Flash vacuum pyrolysis (FVP) uses very low pressures of $10^{-3} \mathrm{~mm}$ or less, high temperatures in the range of $500-1100{ }^{\circ} \mathrm{C}$, short contact times in the order of milliseconds, and short distance for short time of flight before analysis or collection. ${ }^{68}$ Scott employed the FVP method for the synthesis of various bowl-shaped compounds. The investigation was inspired by the reports of R.F.C. Brown that terminal 
acetylene $\mathbf{1 0 5}$ and vinylidene $\mathbf{1 0 6}$ are in equilibrium via 1,2-hydrogen shift under FVP conditions. $^{69}$

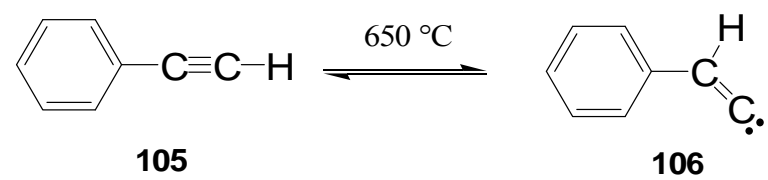

Scheme 29. Equilibrium of terminal acetylene and vinylidene under FVP condition.

The synthesis of corannulene illustrated below shows that 7,10-diethynylfluoranthene (107) was cyclized to form corannulene (102) under FVP conditions via two vinylidene moieties which were trapped by insertions into nearby $\mathrm{C}-\mathrm{H}$ bonds. ${ }^{70}$

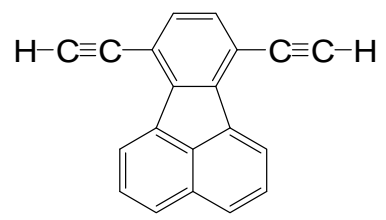

107

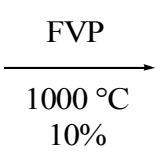

Scheme 30. Synthesis of corannulene via two vinylidene moieties.

Since Scott's pioneering work, many curved molecules have been synthesized by the FVP method. Recently, Scott et al. reported the first rational synthesis of $\mathrm{C}_{60}$ via the pyrolytic method. ${ }^{75 a}$ However, the FVP method is problematic due to the limitation of relatively small scale runs, very low yields, a lack of functional group tolerance, and the potential for thermal rearrangements of the molecular framework. ${ }^{75 b}$ Accordingly, many organic chemists are interested in finding nonpyrolytic methods for the synthesis of bowl-shaped PAHs. ${ }^{76 a}$ "The first production of $\mathrm{C}_{60}$ by physicists adopting not-so-rational methods was so embarrassing to the synthetic chemists that many synthetic chemistry groups were set out to achieve the synthesis of $\mathrm{C}_{60}$ by rational means." $76 \mathrm{~b}$ 


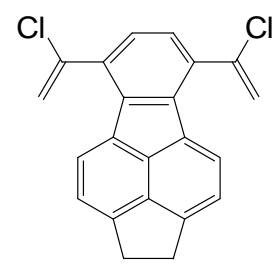

108

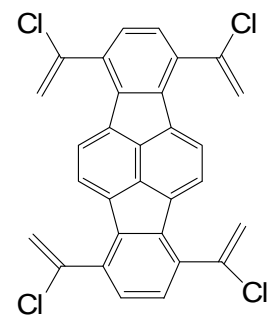

112

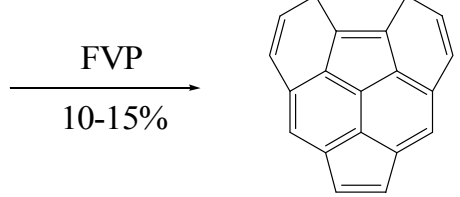

109

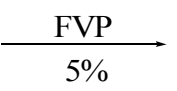

Scheme 31. Curved molecules prepared by the FVP method. ${ }^{11-74}$

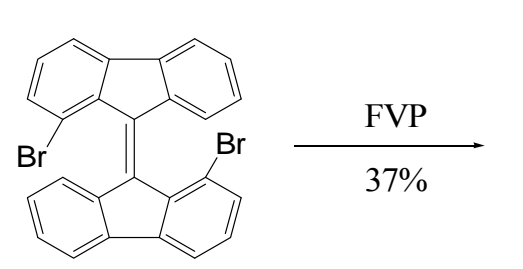

110

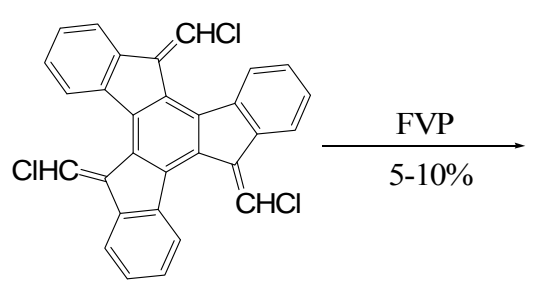

114

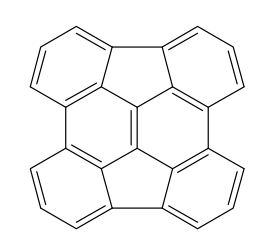

111

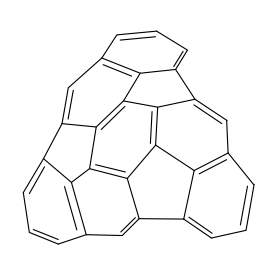

115

As introduced earlier, corannulene synthesis in a solution-phase was reported by Siegel and co-workers in 1996. 2,6-Dimethylcorannulene (104) was synthesized from diketone 116 by condensation with 4-heptanone to produce cyclopentanone carbinol 117, which was brominated to form tetrabromide 103. The reductive coupling strategy using $\mathrm{TiCl}_{3} / \mathrm{LiAlH}_{4}$ or $\mathrm{VCl}_{3} / \mathrm{LiAlH}_{4}$ was employed for internal cyclization of $\mathbf{1 0 3}{ }^{67}$

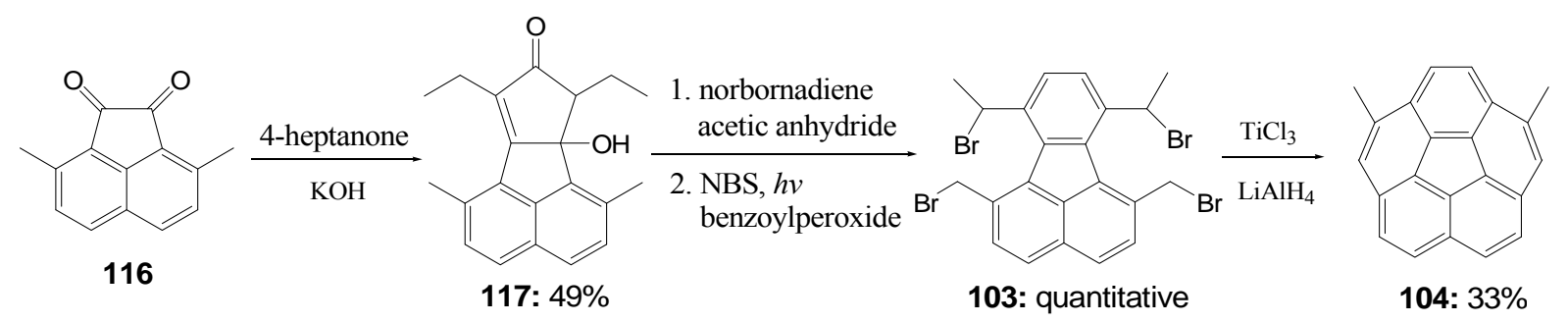

Scheme 32. Corannulene synthesis reported by Siegel.

In 1999 , the Rabideau group improved the yield up to $70-75 \%$ by using benzylic dibromide 119, instead of benzylic monobromide 103. ${ }^{77}$ They used 8.8 equivalent of NBS in

refluxing benzene with a catalytic amount of dibenzoyl peroxide under sun lamp irradiation to produce 119. 


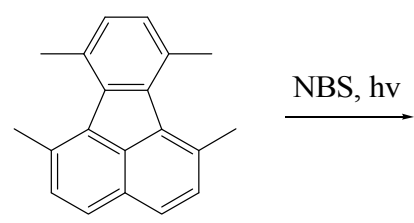

118

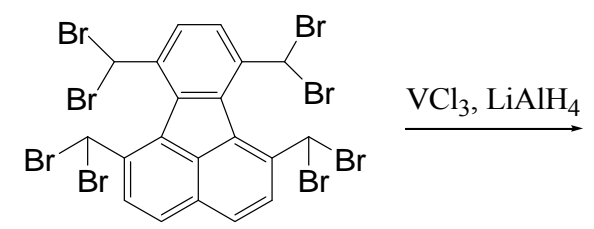

119: $74 \%$

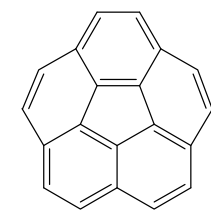

102: $70-75 \%$

Scheme 33. Improved corannulene synthesis reported by Rabideau.

In 2000, Sygula and his collaborators reported an inexpensive and convenient synthetic route to 1,2,5,6-tetrabromocorannulene (120) in $83 \%$ yield, in which they used a small amount of $\mathrm{NaOH}$ in aqueous dioxane to promote ring closures. Compared to this route (Scheme 34), the previous synthetic sequence reported by Siegel required strict oxygen- and moisture-free conditions and 2 to 4 days of reaction time. ${ }^{78}$

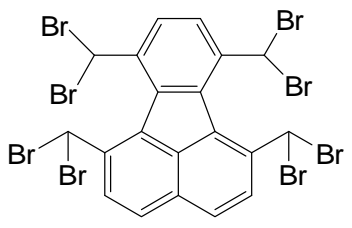

119

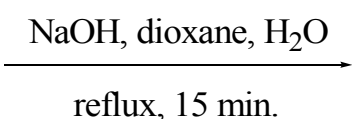

reflux, $15 \mathrm{~min}$.

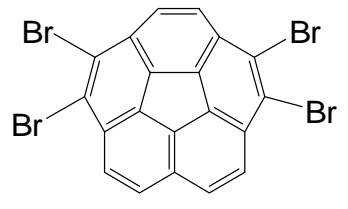

120: $83 \%$

Scheme 34. A simple corannulene synthesis reported by Sygula.

Another powerful catalytic method was employed in 2000 by the Scott group to produce strained fullerene fragments. The procedure employed intramolecular palladium-catalyzed aryl-aryl coupling reactions, which involved mild reaction conditions, allowed wide fuctional group tolerance, and the possibility for scaling-up. ${ }^{75 b}$

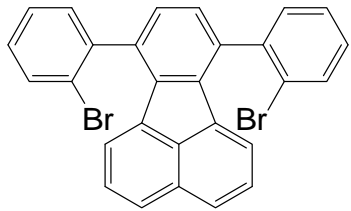

121

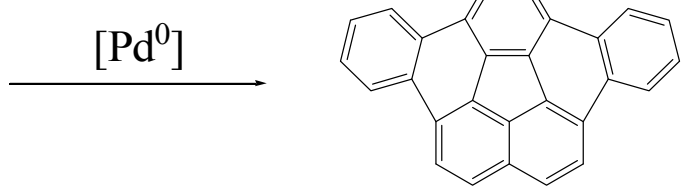

122

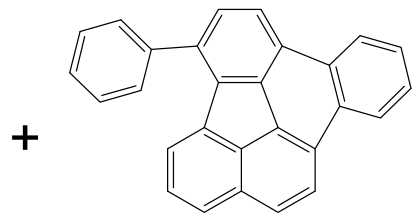

123

Scheme 35. Corannulene synthesis via palladium-catalyzed aryl-aryl coupling reactions.

\section{Research Objective}


Our group reported an efficient route to 5-phenyl-11H-benzo[b]fluorenes (131) involving condensation between benzannulated enediynes and aryl ketones to produce benzannulated enediynyl propargylic alcohols followed by reduction to trigger a sequence of temdem cyclization reactions. ${ }^{14}$ Lithium acetylide 125 and 2,2-dimethylpropiophenone (124) were condensed to furnish propargylic alcohol 126, which was then reduced with triethylsilane and trifluoroacetic acid to furnish the benzannulated enediyne 127. Enediyne 127 was treated with potassium $t$-butoxide under refluxing toluene leading to $\mathbf{1 3 1}$ via a sequence of cascade reactions. Benzannulated enyne-allene $\mathbf{1 2 8}$ was formed initially which then underwent a Schmittel cyclization reaction to give $\mathbf{1 2 9}$, which then underwent a radical-radical coupling to give $\mathbf{1 3 0}$ and then $\mathbf{1 3 1}$.
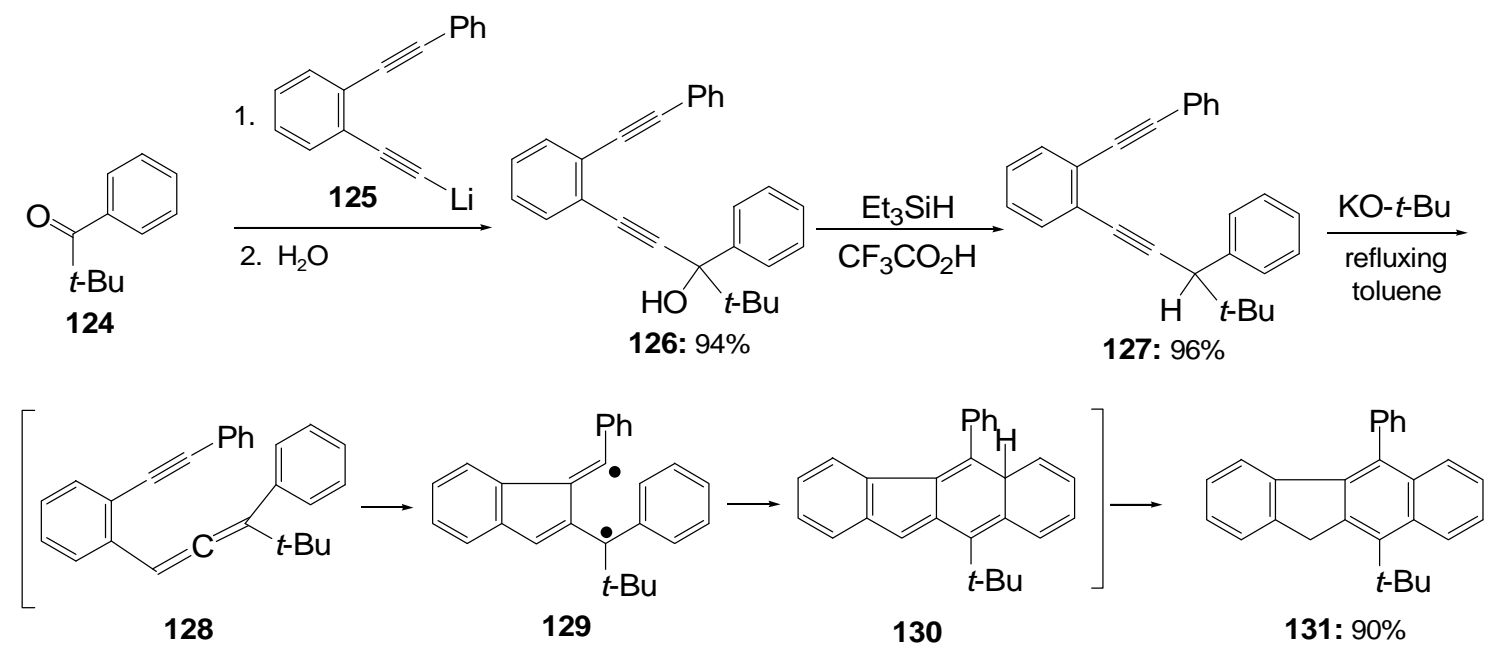

Scheme 38. Synthesis of $11 H$-benzo[b]fluorene via a Schmittel cyclization reaction.

We have adopted this synthetic sequence to furnish the corresponding 5-(2,6-dibromophenyl)-11H-benzo[b]fluorene (132), the precursor for the subsequent palladium-catalyzed intramolecular arylation reactions, leading to buckybowls. 


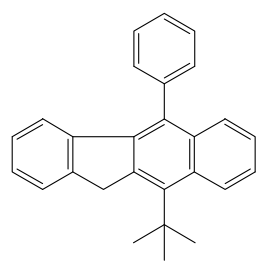

131
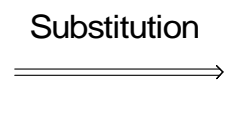

31

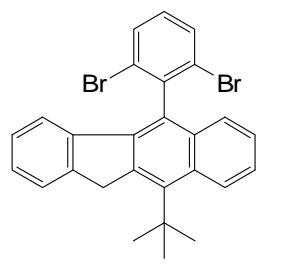

132

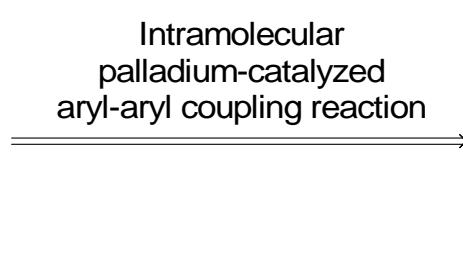

palladium-catalyzed

ryl-aryl coupling reaction

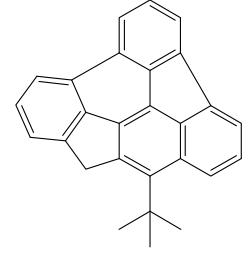

133

Scheme 39. Synthetic route for buckybowl.

Differernt type of buckybowls could be prepared by chaging ketones at the beginning of the synthetic sequences.

\section{Results and Discussions}

The requisite (2,6-dibromophenyl)ethyne (134) was prepared by the Sonogashira coupling reaction between 1,3-dibromo-2-iodobenzene and (trimethylsilyl)ethyne, followed by desilylation as reported previously. ${ }^{81} \mathrm{~A}$ second Sonogashira reaction between $\mathbf{1 3 4}$ and 1-(2-iodophenyl)-2-(trimethylsilyl)ethyne (135) then led to $\mathbf{1 3 6},{ }^{82}$ which was readily desilyated to afford the benzannulated enediyne $\mathbf{1 3 7}$ as shown in Scheme 40. Condensation between 137 and pivalophenone 122 then produced enediynyl propargylic alcohol 138 . Treatment of $\mathbf{1 3 8}$ with triethylsilane in the presence of trifluoroacetic acid then afforded $\mathbf{1 3 9}$. On exposure to potassium tert-butoxide in refluxing toluene for twelve hours, 139 was converted to 5-(2,6-dibromophenyl)-10-(1,1-dimeth-ylethyl)-11H-benzo[b]fluorene (132) in a single operation. The transformation from 139 to 140 presumably proceeded through an initial 1,3-protropic rearrangement to form the corresponding benzannulated enyne-allene 140. A Schmittel cyclization reaction ${ }^{33 a b}$ to generate biradical $\mathbf{1 4 1}$ for an intramolecular radical-radical coupling to afford, in situ, $\mathbf{1 4 2}$ followed by a second prototropic rearrangement to regain aromaticity then furnished $\mathbf{1 3 2}$ as proposed previously. ${ }^{51 \mathrm{~g}}$ 


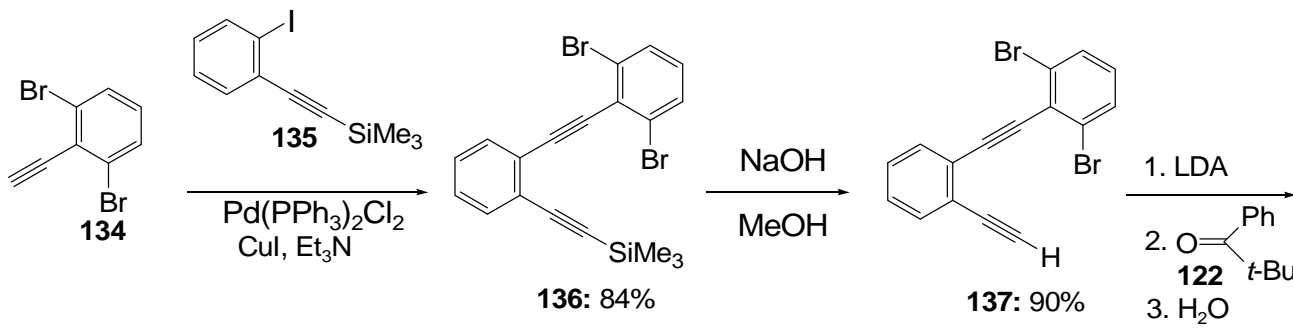

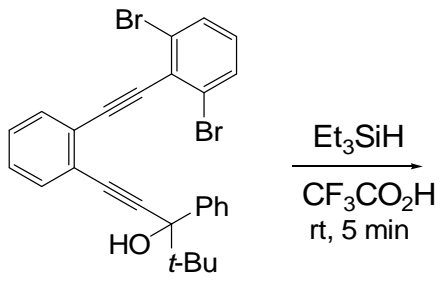

138: $74 \%$

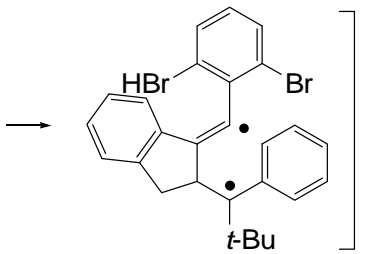

141

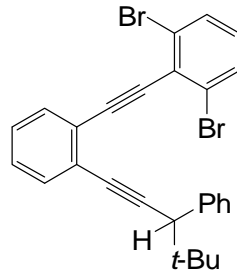

139: $93 \%$

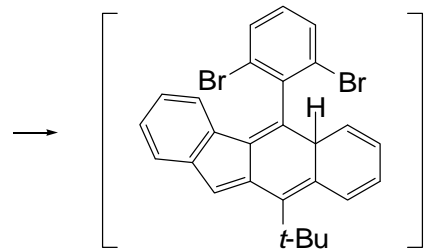

142

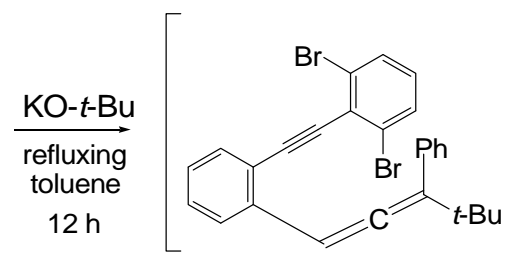

140

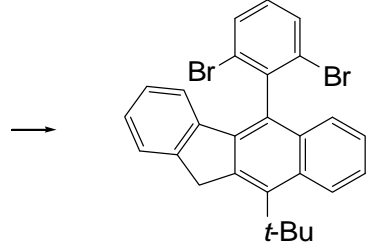

132: $70 \%$

Scheme 40. Synthesis of 5-(2,6-dibromophenyl)-10-(1,1-dimeth-ylethyl)-11H-benzo[b]fluorene.

It gave us great pleasure to observe that treatment of 132 with 10 mol \% of $\mathrm{Pd}\left(\mathrm{PPh}_{3}\right)_{2} \mathrm{Br}_{2}$ in the presence of DBU under the conditions reported by Scott $e t$ al. ${ }^{75}$ produced buckybowl 133 (Scheme 41). The structure of 133 was confirmed by X-ray structure analysis (Figure 6). Similar to what was observed previously, ${ }^{69}$ reductive debromination either on one side or on both sides also occurred, giving rise to the monoclosed hydrocarbon $\mathbf{1 3 4}$ as a minor product and a small amount of $\mathbf{1 3 2}$, respectively. The structure of 143 was tentatively assigned, based on the assumption that the first cyclopalladation reaction of $\mathbf{1 3 2}$ occurred preferentially with the naphthyl moiety of $\mathbf{1 3 2}$ producing a five-membered ring as reported previously. ${ }^{83}$ The resulting brominated fluoranthene intermediate could undergo either a second cyclopalladation reaction to produce $\mathbf{1 3 3}$ or a reductive debromination reaction to give $\mathbf{1 4 3}$. Analysis of the crude reaction mixture by GC/MS before purification by silica gel chromatography also suggests the presence of a small amount of $\mathbf{1 3 1}$. 


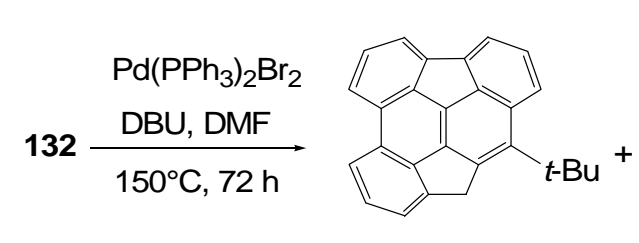

133: $37 \%$

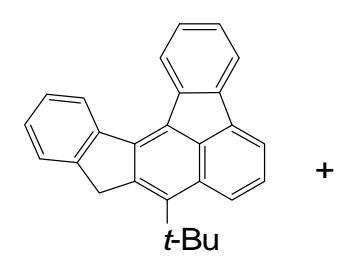

143: $16 \%$

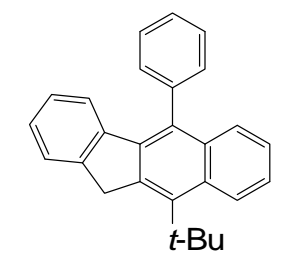

131: trace

Scheme 41. Synthesis of buckybowls via palladium-catalyzed aryl-aryl coupling reaction.

The X-ray structure of $\mathbf{1 3 3}$ indicates the presence of a significant curvature. Compared to 111, the structure of $\mathbf{1 3 3}$ appears to be less strained with one less ring due to the absence of three $\mathrm{sp}^{2}$-carbons in the southeastern corner.
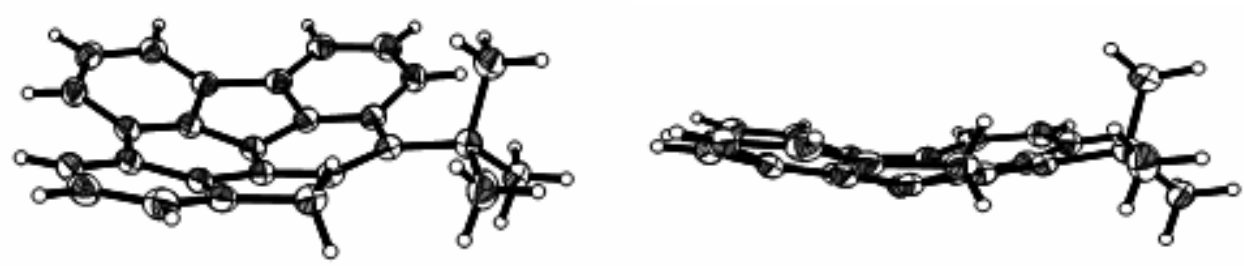

Figure 6. ORTEP drawings of the crystal structure of $\mathbf{1 3 3 .}$

The pyramidalization angle, defined as $\Theta_{\sigma \pi}-90$ using the $\pi$-orbital axis vector analysis (POAV1), ${ }^{84}$ of the central ethylene carbon atoms of 111 was reported to be $9.0^{\circ}$, whereas the pyramidalization angle of the four carbon atoms attached to the central double bond was determined to be $6.7^{\circ}$ (Figure 7). ${ }^{85}$ The POAV1 angles of these carbon atoms are clearly larger than those of the corresponding carbon atoms of $\mathbf{1 3 3}$ based on the geometry obtained from the X-ray analysis.

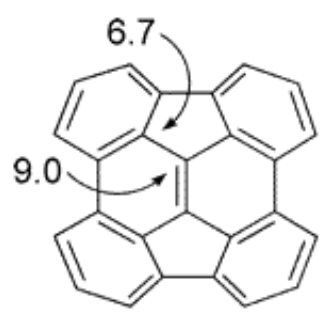

111

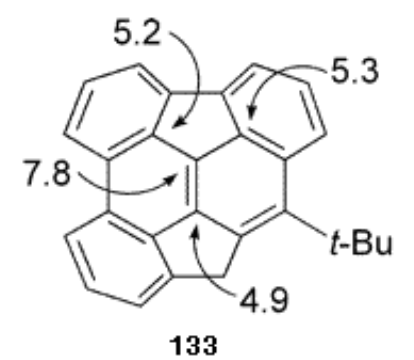

133

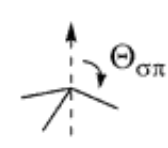

POAV1 Vector

Figure 7. POAV1 pyramidalization angles $\left(\Theta_{\sigma \pi}-90\right)$ of 111 and 133. 
The ${ }^{1} \mathrm{H}$ NMR signal of the diastereotopic methylene hydrogens of $\mathbf{1 3 3}$ occurs as a singlet at $\delta 4.75 \mathrm{ppm}$. Barring accidental isochrony, this observation suggests a rapid bowl-to-bowl inversion on the NMR time scale at room temperature, reminiscent of what was observed previously in substituted corannulene derivatives. ${ }^{86}$ Similarly, by using aryl ketones 144a and $144 b^{51 g}$ for condensation with the lithium acetylide of 137 , benzannulated enediynyl propargylic alcohols $\mathbf{1 4 5 a}$ and $\mathbf{1 4 5 b}$ were obtained, respectively. Reduction with triethylsilane in the presence of trifluoroacetic acid then gave benzannulated enediynes 146a and 146b. Treatment of 146a and $\mathbf{1 4 6 b}$ with potassium tert-butoxide in refluxing toluene for $12 \mathrm{~h}$ then furnished 147a and $\mathbf{1 4 7 b}$, respectively. The palladium-catalyzed intramolecular arylation reactions of 147a produced buckybowl 148a and the monocyclized hydrocarbon 149a.

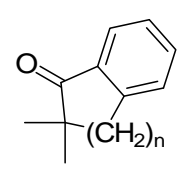

144a: $n=2$ 144b: $n=1$

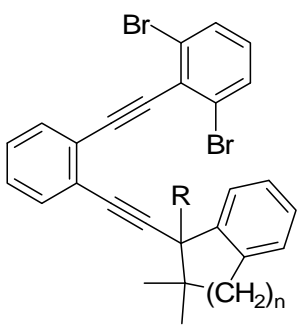

145a: $n=2, R=O H, 69 \%$

145b: $n=1, R=O H, 65 \%$

146a: $n=2, R=H, 89 \%$

146b: $n=1, R=H, 89 \%$

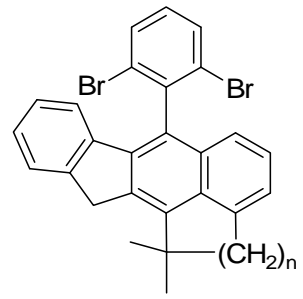

147a: $\mathrm{n}=2,66 \%$ 147b: $n=1,62 \%$

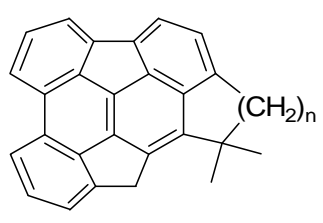

148a: $n=2,42 \%$ 148b: $n=1,11 \%$

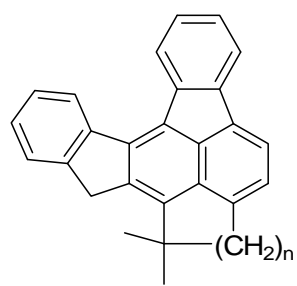

149a: $\mathrm{n}=2,21 \%$ 149b: $n=1,23 \%$

Figure 8. Synthesis of bowl-shaped PAHs 148 from ketone 144.

The X-ray structure of 148a also indicates the presence of a significant curvature. Similarly, buckybowl 148b along with the monocyclized hydrocarbon $\mathbf{1 4 9 b}$ were likewise

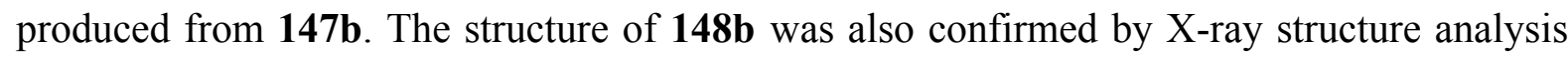
(Figure 8). The presence of an additional five-membered ring in $\mathbf{1 4 8 b}$ appears to cause its structure to be more strained than those of 133 and 148a. As a result, the transformation from $147 \mathrm{~b}$ to $148 \mathrm{~b}$ is less efficient, and the yield of $\mathbf{1 4 8 b}$ was lowered to $11 \%$ along with $23 \%$ of the mono-closed product $\mathbf{1 4 9 b}$. 


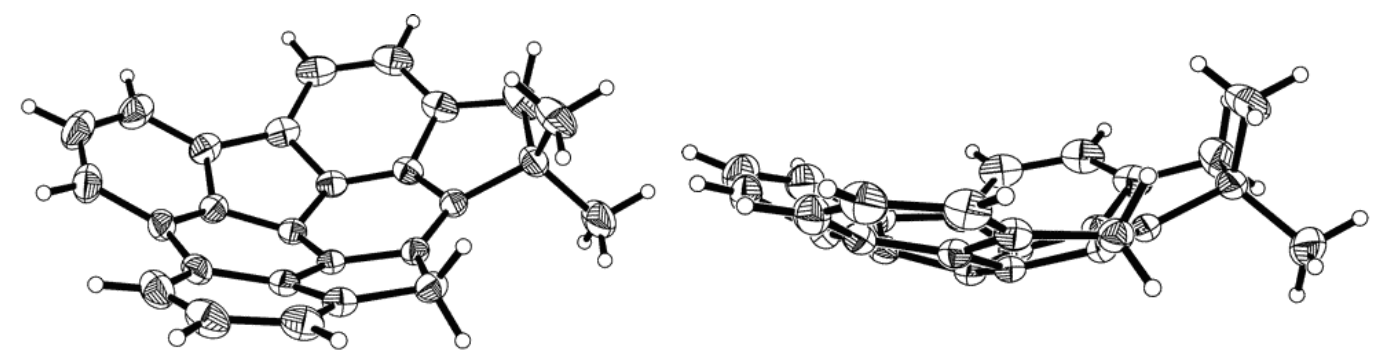

Figure 9. ORTEP drawing of the crystal structure of $\mathbf{1 4 8 b}$.

Based on the geometry obtained from the X-ray analysis, one of the central carbon atoms of $\mathbf{1 4 8 b}$ has a POAV1 angle of $10.3^{\circ}$ (Figure 9), which is larger than those of $\mathbf{1 1 1}$ and corresponds to $88 \%$ of that found for $\mathrm{C}_{60}$ with all carbon atoms having a POAV1 angle of $11.64^{\circ}$. In addition, one of the four carbon atoms attached to the central double bond of $\mathbf{1 4 8 b}$ has a POAV1 angle of $9.2^{\circ}$, which is also larger than those of the corresponding carbon atoms of 111.

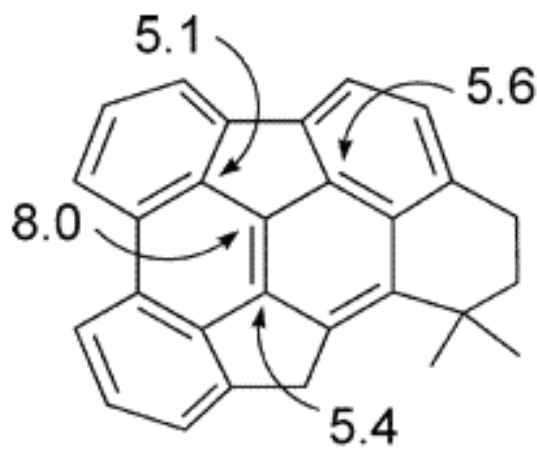

148a

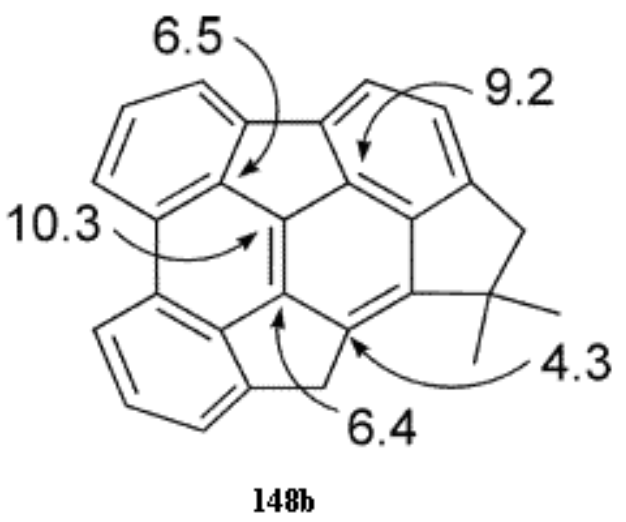

$148 \mathrm{~b}$

Figure 10. POAV1 pyramidalization angles of $148 \mathrm{a}$ and $\mathbf{1 4 8 b}$.

It was reported that, unlike corannulene, dihydrocyclopentacorannulene with an additional five-membered ring "locked" the bowl configuration, preventing a rapid bowl-to-bowl inversion process. ${ }^{87}$ However, no such effect was observed for $\mathbf{1 4 8 b}$ with the two sets of the methylene hydrogens appeared as two sharp singlets at $\delta 4.41$ and 3.29 and the two groups of methyl hydrogens appeared as a sharp singlet at $\delta 1.63$ at $25{ }^{\circ} \mathrm{C}$. At $-33{ }^{\circ} \mathrm{C}$, the methylene signals, recorded on a 600-MHz NMR spectrometer, became two broad humps 
ranging from ca. $\delta 4.6$ to 4.2 and from ca. $\delta 3.4$ to 3.1 , and the methyl signal also appeared as a broad peak ranging from ca. $\delta 1.8$ to 1.5 . Further broadening but without the appearance of distinct signals for the diastereotopic hydrogens was observed at $-40{ }^{\circ} \mathrm{C}$, suggesting relatively fast bowl-to-bowl inversion on the NMR time scale even at $-40{ }^{\circ} \mathrm{C}$.

\section{Conclusion}

A new synthetic route to buckybowls was developed. The convergent assembly of the benzannulated enediynyl propargylic alcohols and the efficient cascade cyclizations of the resulting enyne-allenes leading to polycyclic aromatic dibromides for subsequent palladium-catalyzed intramolecular arylation reactions are the key features of this synthetic pathway. The use of benzannulated enediynyl propargylic alcohols to form the corresponding aromatic dibromides represents a new approach to the preparation of buckybowl precursors. Three new buckybowls with their structures confirmed by X-ray structure analyses were thus synthesized. 


\section{Part III \\ Synthesis of $\mathrm{C}_{2}$-Symmetrical homo-bi-dentate Ligands \\ bearing a 4,5-Diarylphenanthrene Moiety}

\section{Introduction}

Development of effective catalytic asymmetric reactions promoted by chiral synthetic catalysts is an important area of research. ${ }^{88} \mathrm{~W}$. Marckwald provided a definition of asymmetric reaction as "Asymmetric syntheses are those reactions which produce optically active substances from symmetrically constituted compounds, with intermediate use of optically active materials. ${ }^{\prime 89}$ The progress of this research area has seen rapid advance in recent years in using organometallic catalysts, enzymes, and chiral auxiliaries to promote asymmetric synthesis. ${ }^{90}$ One of the most widely used chiral ligands for catalytic asymmetric reactions is BINOL 149a, (1,1'-binaphthyl-2,2'-diol), which was first synthesized as a racemate in 1873 with the absolute configuration established in $1979 .{ }^{91}$

In 1979, Noyori demonstrated the extremely high stereoselectivity (99\%) of carbonyl group reduction by a binaphthol-modified aluminuim hydride reagent. ${ }^{92}$ Takaya and Noyori then reported that the Rh and Ru complexes of BINAP 149b, (2,2'-bis(diphenylphosphine)-1, 1'-binaphthyl), are excellent complexed chiral ligands for the asymmetric hydrogenation of

olefins and carbonyl compounds. ${ }^{93}$ The success of BINAP complexes of ruthenium, rhodium, and palladium stimulated the development of a wide variety of $\mathrm{C}_{2}$-symmetrical homo-bi-dentate ligands and non- $\mathrm{C}_{2}$-symmetrical hetero-bi-dentate ligands. 


\section{$\mathrm{C}_{2}$-symmetrical homo-bi-dentate ligands}<smiles>Oc1ccc2ccccc2c1-c1c(O)ccc2ccccc12</smiles>

149a: BINOL<smiles>c1ccc(P(c2ccccc2)c2ccc3ccccc3c2-c2c(P(c3ccccc3)c3ccccc3)ccc3ccccc23)cc1</smiles>

149b: BINAP<smiles>Nc1ccc2ccccc2c1-c1c(N)ccc2ccccc12</smiles>

149c: BINAM

non- $\mathrm{C}_{2}$-symmetrical hetero-bi-dentate ligands<smiles>COc1ccc2ccccc2c1-c1c(P)ccc2ccccc12</smiles>

150a: MOP<smiles>Nc1ccc2ccccc2c1-c1c(O)ccc2ccccc12</smiles>

150b: NOBIN<smiles>CN(C)c1ccc2ccccc2c1-c1c(P)ccc2ccccc12</smiles>

150c: MAP

BINAP ( 2,2'-bis(Diphenylphosphino)-1,1'-binaphthyl) BINAM (1,1'-Binaphthalene-2,2'-diamine) MOP (2-(Diphenylphosphino)-2-methoxy-1,1'-binaphthyl) NOBIN (2-Amino-2-hydroxy-1,1'-binaphthyl) MAP (2-Dimethylamino-2'-diphenylphosphino-1,1'-binaphthyl)

Figure 11. A variety of $\mathrm{C}_{2}$-symmetrical bidentate ligands.

\section{Research Objective}

4,5-Disubstituted phenanthrenes have a helical twist imposed by the two substituents bent out of the plane of the aromatic rings. The angle of 4,5-dimethylphenanthrene 151 between the outer ring planes is $27.9^{\circ}$, and its enantiomers were separated by chiral column..$^{94}$<smiles>Cc1cccc2ccc3cccc(C)c3c12</smiles>

$151 a$<smiles>Cc1cccc2ccc3cccc(C)c3c12</smiles>

$151 b$<smiles></smiles>

$152 a$<smiles>C1=Cc2cccc3cccc(c23)C(c2ccccc2)=C1</smiles>

$152 b$

Figure 12. 4,5-Disubstituted phenanthrenes.

Dr. Hongbin Li in our group synthesized the twisted PAH bearing 4,5-diphenylph- 
enanthrene moiety via $\mathrm{C}^{2}-\mathrm{C}^{6}$ cyclization reaction of the benzannulated enyne-allenes. He demonstrated that the $\mathrm{C}^{2}-\mathrm{C}^{6}$ cyclization reaction could be used for the synthesis of 4,5-diarylphenanthrenes (157). ${ }^{47 \mathrm{c}}$ The synthetic sequence involves the condensation of 2 equiv of the lithium acetylide 153 with $\mathbf{1 5 4}$ to form the propargylic alcohols $\mathbf{1 5 5}$. The reduction of 155 with triethylsilane in the presence of trifluoroacetic acid gave rise to the tetraacetylenic hydrocarbons 156. Treatment of $\mathbf{1 5 6}$ with potassium tert-butoxide in refluxing toluene at 110 ${ }^{\circ} \mathrm{C}$ then furnished 4,5-diarylphenanthrenes 157.

\section{1. $n$-BuLi}

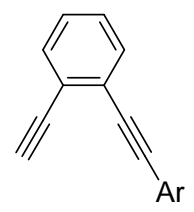

2.

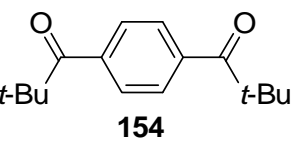

3. $\mathrm{H}_{2} \mathrm{O}$

153a: $\mathrm{Ar}=\mathrm{Ph}$

153b: Ar = 4-biphenylyl

153c: $\mathrm{Ar}=3,5$-dimethylphenyl

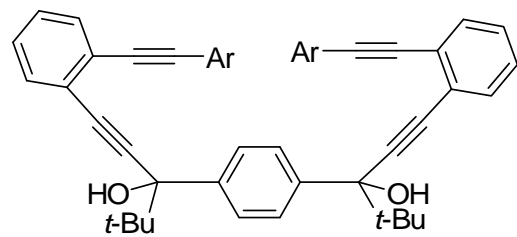

155a: $92 \%$

155b: $92 \%$

155c: $98 \%$
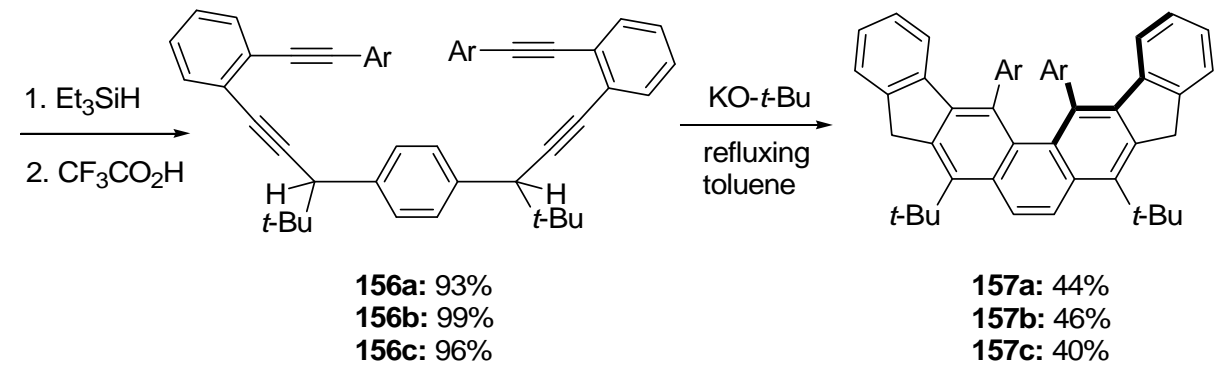

Scheme 41. Synthesis of 4,5-diarylphenanthrenes.

The most attractive feature of this cyclization reaction was the fact that uniquely twisted polycyclic aromatic hydrocarbon was formed in just a few steps. X-ray crystal structure (Figure 13) of 157a from two different perspectives showed that the structure is severely twisted due to nonbonding steric interactions of phenyl groups which are oriented essentially parallel to each other. There is a $46.1^{\circ}$ twist between the mean planes of the outer rings of the phenanthrene system. 

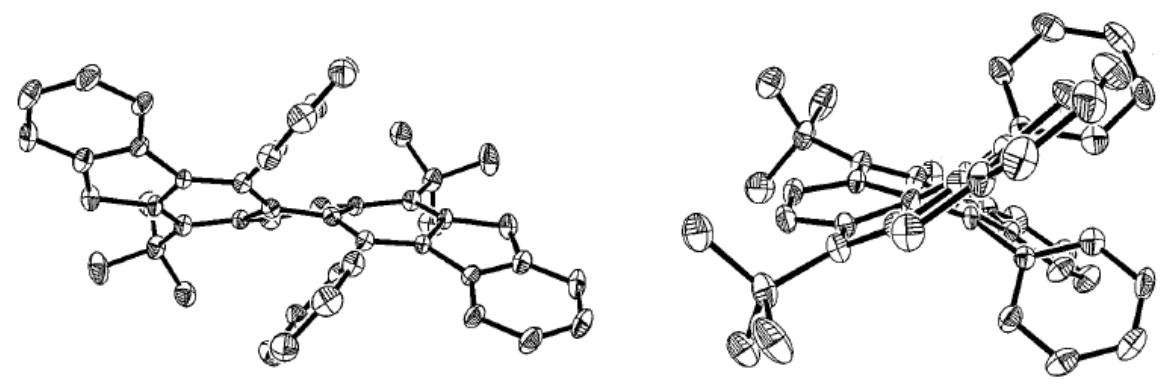

Figure 13. ORTEP drawings of 4,5-diarylphenanthrene 157a. ${ }^{47 c}$

Based on Dr. Li's discovery, we have further pursued the use of properly fuctionalized 157 as $\mathrm{C}_{2}$-symmetrical homo-bi-dentate ligands or chiral auxiliaries for enantioselective reduction or oxidation reactions. We envisioned that replacing the phenyl groups with phenol or aniline group could lead to the formation of $\mathrm{C}_{2}$-symmetrical homo-bi-dentate 4,5-diarylphenanthrene containing the necessary fuctional groups for metal coordination resembling those of BINOL, and related derivatives (Figure 14).
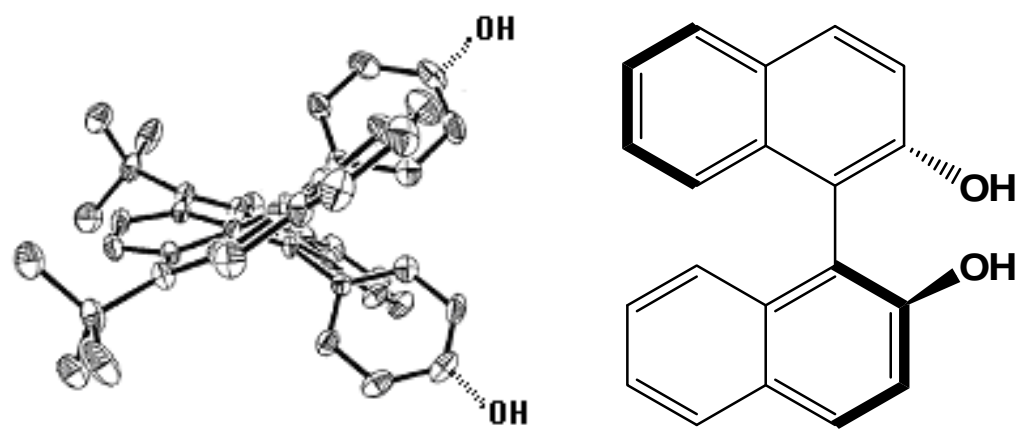

Figure 14. 4,5-Diarylphenanthrene bearing helical twisted phenolic groups.

\section{Results}

\subsection{Synthesis of a diindeno-fused 4,5-diarylphenanthrene containing phenolic groups}

The synthetic sequence outlined in Scheme 42 illustrates the synthesis of twisted dianisole 163. Condensation between 1-ethynyl-2-iodobenzene (158) and diketone 154 produced the propargylic alcohol 159. Treatment of $\mathbf{1 5 9}$ with triethylsilane in the presence of trifluoroacetic acid afforded diiodide 160. The Sonogashira coupling reaction between 4-ethynylanisole (161) and diiodide 160 produced the tetraacetylenic compound 162 which 
served as the precursor of the corresponding benzannulated enyne-allene. On exposure to potassium tert-butoxide in refluxing toluene for twelve hours, 162 was converted to 4,5-di(4-methoxyphenyl)phenanthrene $\mathbf{1 6 3}$ in $42 \%$ yield via the cascade cyclization reactions of the corresponding benzannulated enyne-allene.

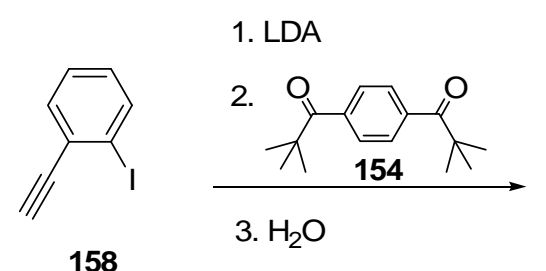

158

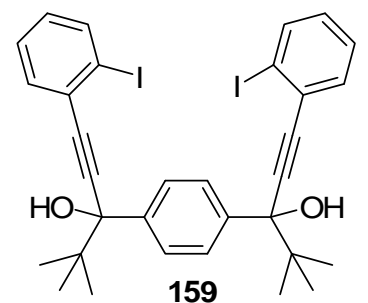

Solubility is bad

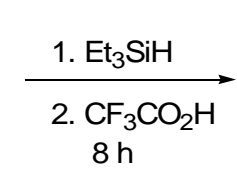

$8 \mathrm{~h}$

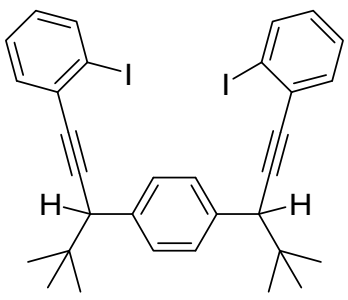

160: $85 \%$

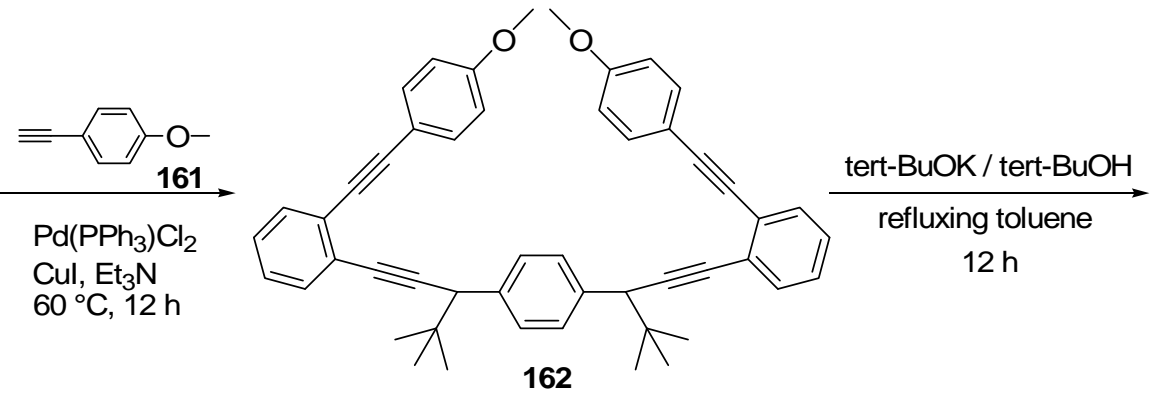

162

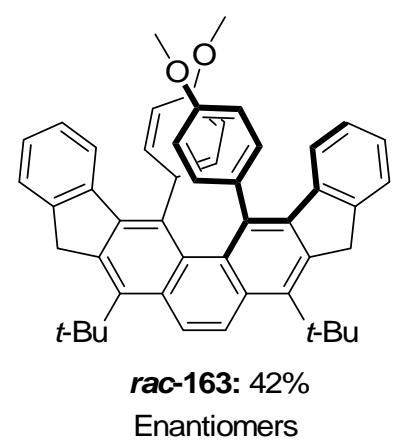

Scheme 42. Synthesis of rac-163 containing a 4,5-di(4-methoxyphenyl)phenanthrene substructure.

The ORTEP drawing of $\mathbf{1 6 3}$ viewing along the axis perpendicular to the phenanthrene ring is given in Figure 15 to show a severe structural distortion. As expected, the two anisole substituents are twisted away from each other.

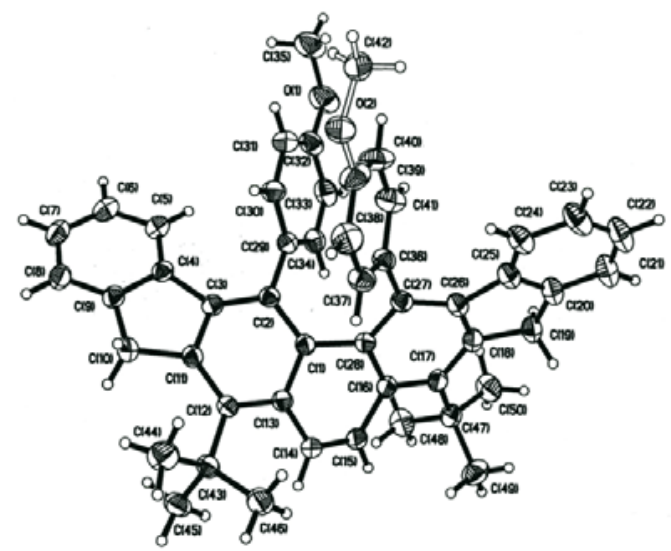

Figure 15. ORTEP drawing of the crystal structure of $\mathbf{1 6 3 .}$ 
The $\mathrm{BBr}_{3}$-mediated deprotection of the methoxy groups in compound $\mathbf{1 6 3}$ gave rise to the rac-diphenolic product $\mathbf{1 6 4 .}$

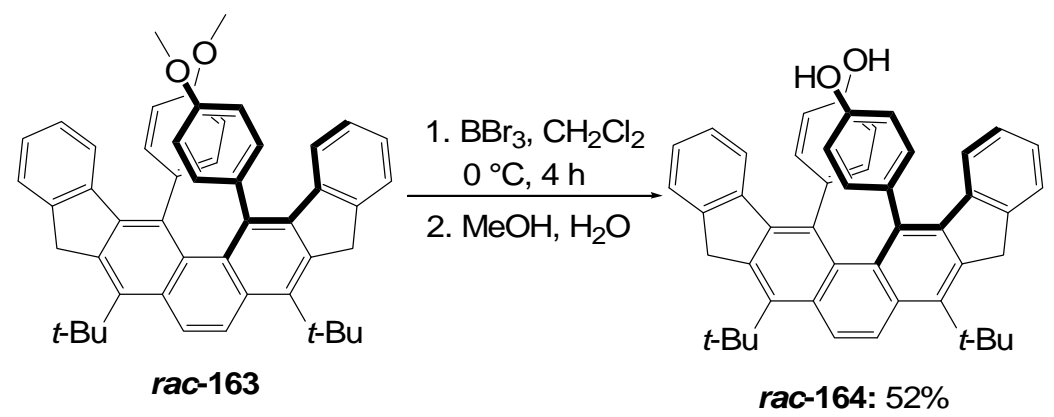

Scheme 43. Demethylation of 4,5-di( $p$-methoxyphenyl)phenanthrene.

\subsection{Resolution of 4,5-diarylphenanthrene containing phenolic groups}

\subsubsection{Literature survey for resolution}

The resolution of $r a c$-BINOL by chemical methods and the selective synthesis of $(R)$ - or $(S)$-BINOL have been extensively studied. The classical method for the chemical resolution of rac-BINOL involved separation of diastereomers derivatized with additional chiral compounds. The chemical resolution of rac-BINOL was first achieved by the synthesis of cyclic binaphthyl phosphoric acids, which were successfully resolved as cinchonine salts. ${ }^{97}$

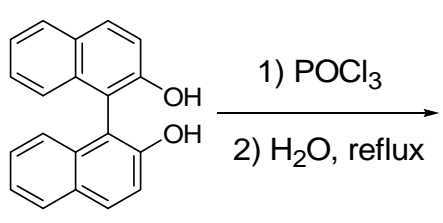

rac-165

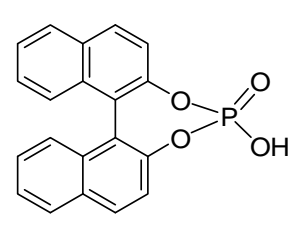

rac-166
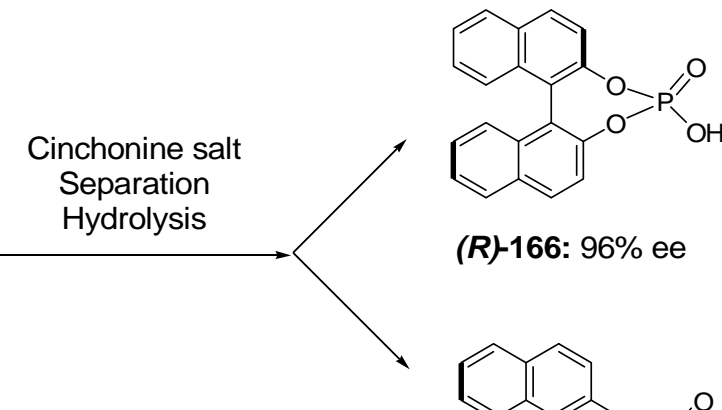

(R)-166: 96\% ee

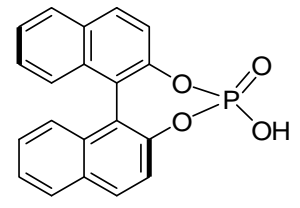

(S)-166: 90\% ee

Scheme 44. Resolution of BINOL with cinchonine salts. 
The resolution of rac-BINOL was also achieved by $\mathrm{Hu}$ and De Lucchi's groups independently, who employed the case of phosphoramidates derived from optically active phenethylamines. It was possible to achieve $100 \%$ ee by using the three amines depicted in Scheme $45 .^{98}$

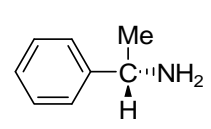

167

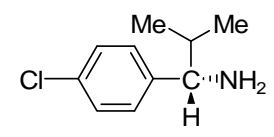

168

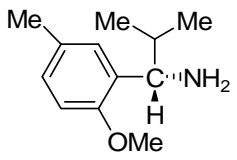

169<smiles>Oc1ccc2ccccc2c1-c1c(O)ccc2ccccc12</smiles>

rac-165

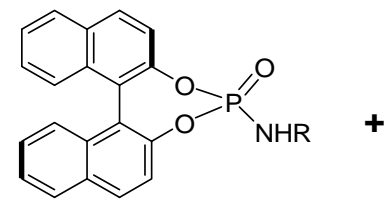

(R,S)-170

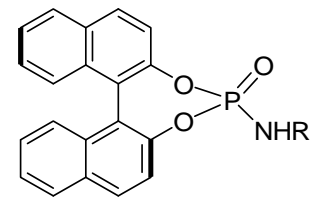

(S,S)-170

Scheme 45. Resolution of BINOL using phosphoramidates derivatization.

In 1995, Fabbri et al. reported that (-)-menthyl chloroformate-derivatized BINOL could be chromatographically separated. After then, two more chiral acyl chlorides, camphor sulfonyl chloride (172) and neomenthylthioacetic acid chloride (173), were employed for the resolution of rac-BINOL. This resolution method has been widely used due to their convenience and low cost. ${ }^{99}$

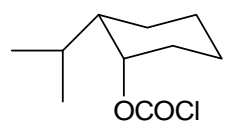

171

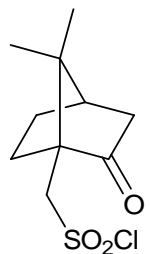

172

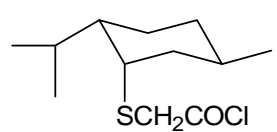

173

Figure 16. Chiral acyl chlorides for the resolution of BINOL.

Resolution with camphor sulfonyl chloride (172) is a facile, inexpensive, and useful method for a simple two-step resolution of rac-BINOL in $80-95 \%$ yield. ${ }^{99(a)}$ Based on the result reported by the Chow's group (Scheme 46), ${ }^{99(a)}$ we envisioned that our rac-biphenolic 
product 164 could be chromatographically resolved through its derivatization with camphor sulfonyl group. Diastereomeric bis- $(S)$-camphorsulfonates 174 could be separated on silica gel column by using a hexane-diethyl ether mixture as eluent.
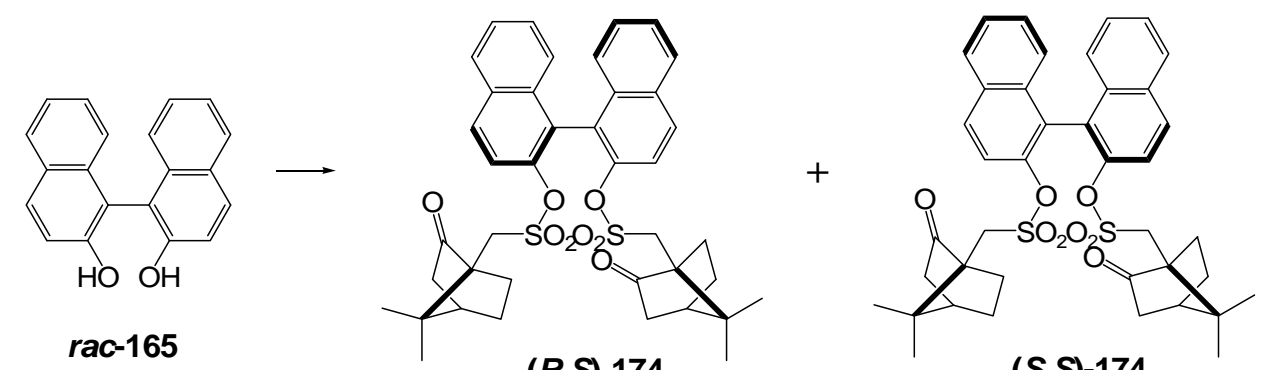

$(S, S)-174$

Scheme 46. Separation of rac-BINOL substituted with camphorsulfonyl group.

\subsubsection{Results of resolution}

Demethylation followed by derivatization with camphorsulfonyl group converted enantiomers of 4,5-di(4-methoxyphenyl)phenanthrene (rac-163) to the corresponding (S)-camphorsulfonate diastereomers 175. We separated P-175 and M-175 on silica gel column chromatography and confirmed their separation on the base of ${ }^{1} \mathrm{H}$ NMR spectra obtained in a $270 \mathrm{MHz}$ NMR spectrometer.
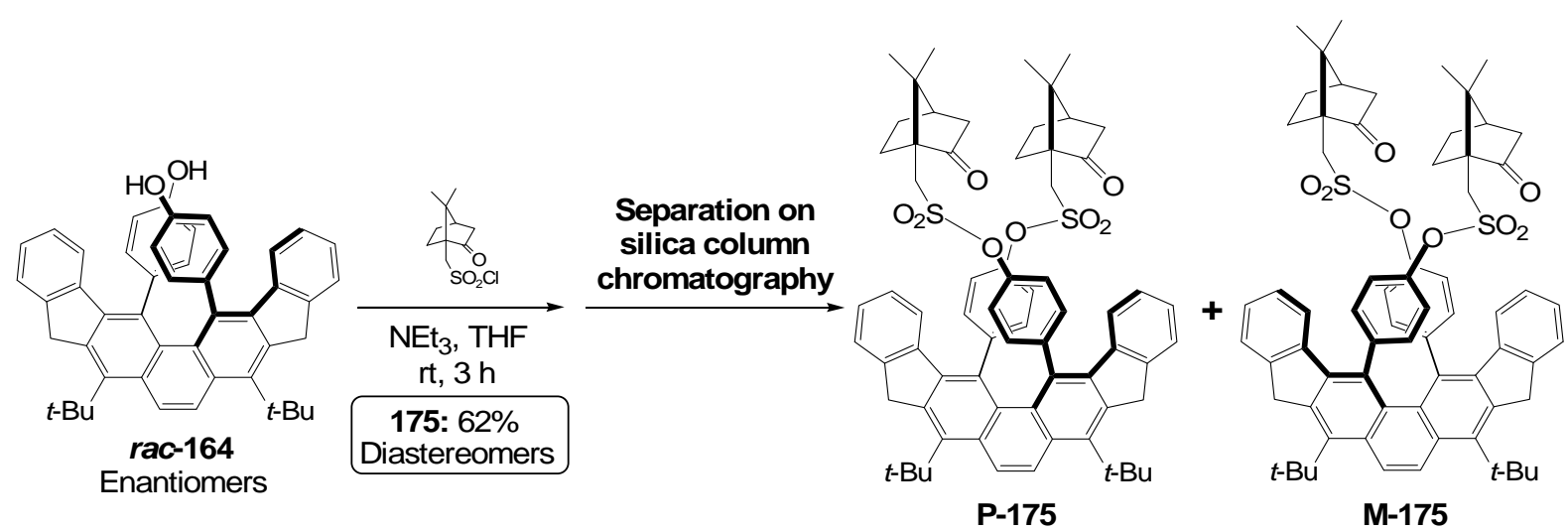

Scheme 47. Preparation and separation of camphorsulfonate derivatives. 
As shown in Figure 17, respective ${ }^{1} \mathrm{H}$ NMR spectra show the two diastereomers were clearly separated on silica gel column chromatography with high diastereomeric purity. Before column chromatography, the NMR signals of the methylene hydrogens on the five-membered rings exhibited two set of $\mathrm{AB}$ quartet signals in the upfield-shift portions of the signals overlap with each other. However, after column chromatography, the separated derivatives exhibit only one set of the $\mathrm{AB}$ quartet signals. In addition, the two doublets at $\delta 6.1$ and 6.2, attributable to the two aromatic hydrogens closest to the phenyl substituents, also showed clean separation after column chromatography. However, the singlets attributable to the two hydrogns on the central benzene ring have identical chemical shift at $\delta 7.8$. Another set of $\mathrm{AB}$ quartets attributable to the methylene groups $\left(-\mathrm{CH}_{2} \mathrm{SO}_{2}-\right)$ were observed at $\delta 3.9(2 \mathrm{H}, \mathrm{d}, J=$ $15.0 \mathrm{~Hz})$ and $3.2(2 \mathrm{H}, \mathrm{d}, J=15.0 \mathrm{~Hz})$ and $3.8(2 \mathrm{H}, \mathrm{d}, J=15.0 \mathrm{~Hz})$ and $3.2(2 \mathrm{H}, \mathrm{d}, J=15.0 \mathrm{~Hz})$, respectively.

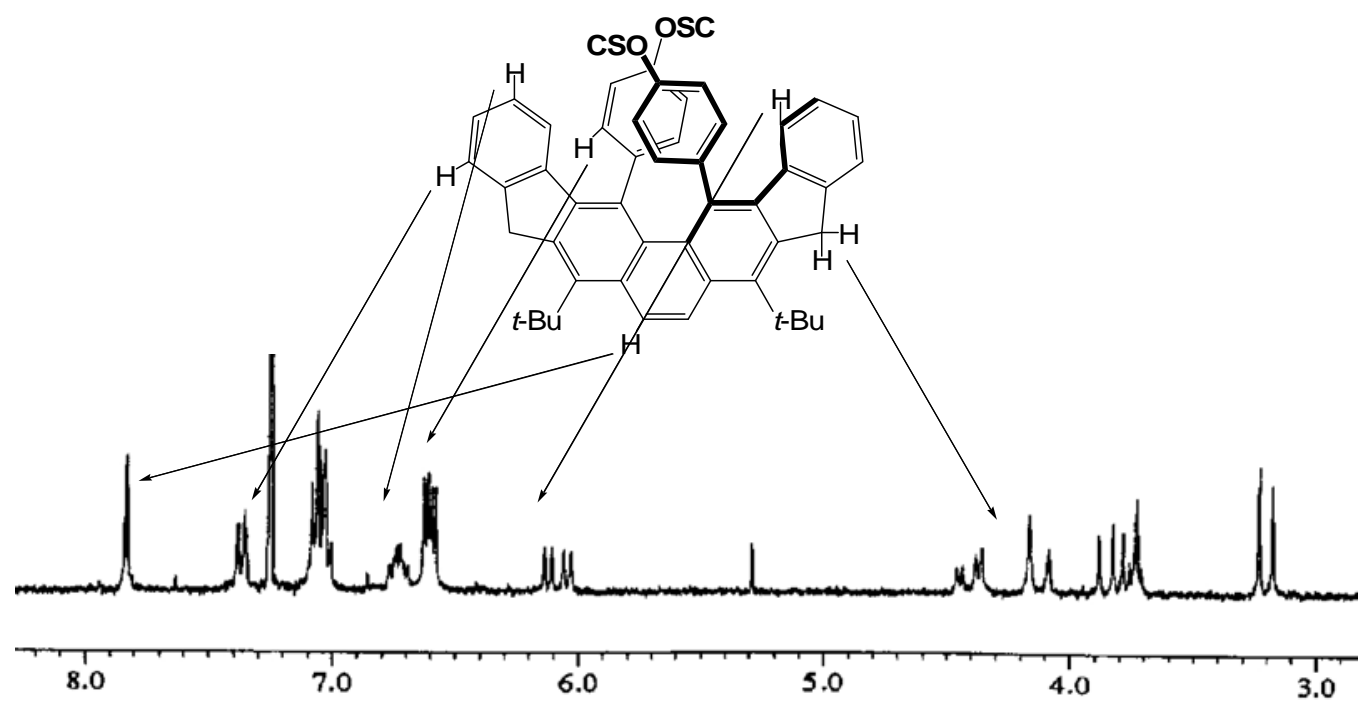

(a) Diastereomers derivatized with camphorsulfonyl group

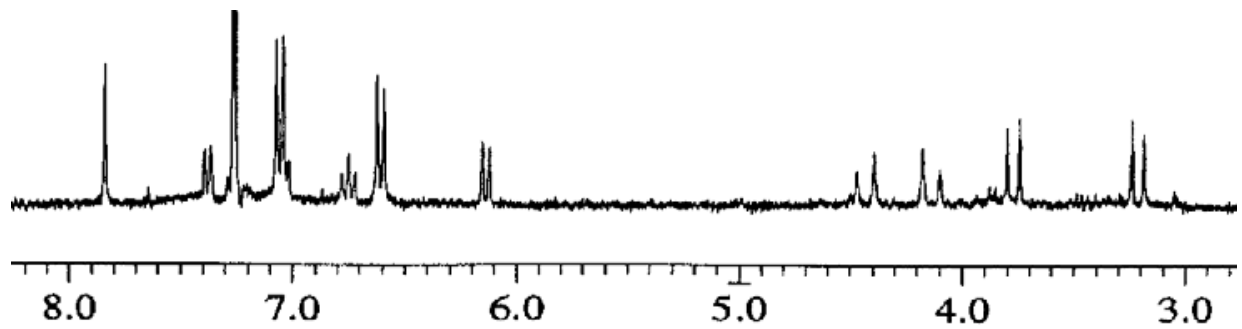

(b) Separated Diastereomer 


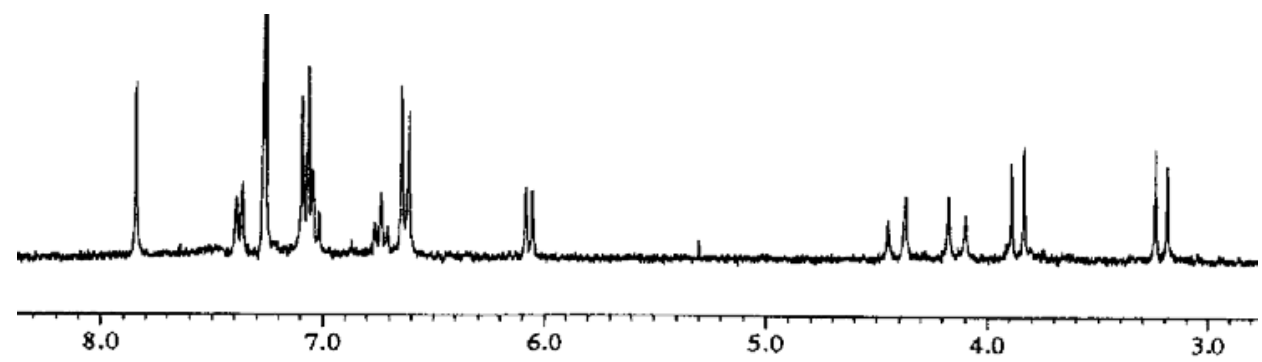

(c) Separated Diastereomer

Figure 17. ${ }^{1} \mathrm{H}$ NMR spectra of camphorsulfonates 175.

Based on our previous experience, the methylene hydrogens on the five-membered ring of $\mathbf{1 6 3}$ are very acidic and can be easily oxidized to keto group under basic conditions. In order to prevent oxidation of the methylene hydrogens, attempts were made to try to replace them with methyl groups by treatment with potassium $t$-butoxide for methylation with iodomethane to furnish the corresponding tetra-methylated compound 176'. However, the X-ray of the product (Figure 18) shows that instead of tetra-methylation, the trans-di-methylated adduct $\mathbf{1 7 6}$ was obtained in 91\% yield. Further methylation to produce 176' was unsuccessful.

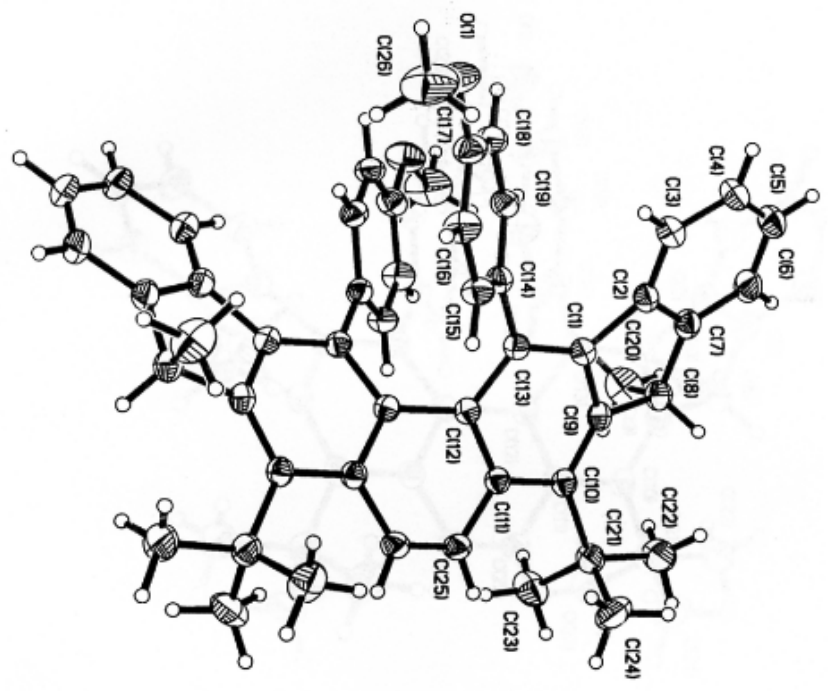

Figure 18. ORTEP drawing of the crystal structure of the di-methylated $\mathbf{1 7 6 .}$ 


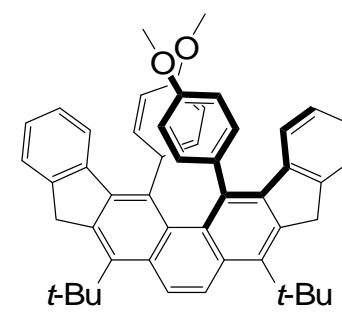

rac-163
1. tert-BuOK / tert-BuOH THF, rt

$$
\text { 2. Mel }
$$

$\mathrm{BBr}_{3}, \mathrm{CH}_{2} \mathrm{Cl}_{2}$

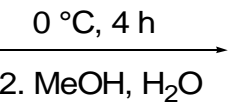
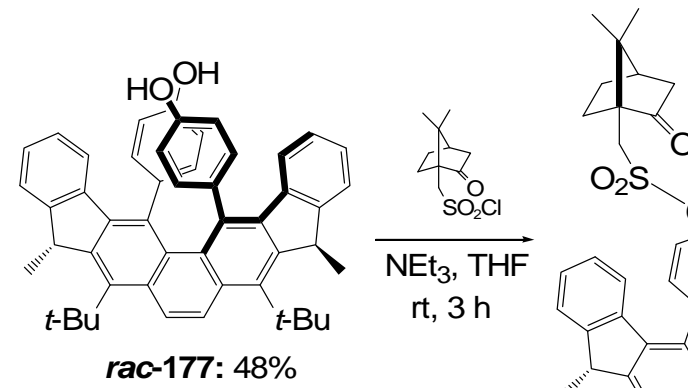

$\mathrm{O}_{2} \mathrm{~S}$

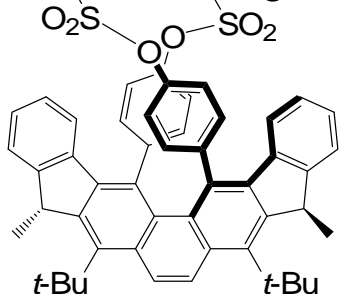

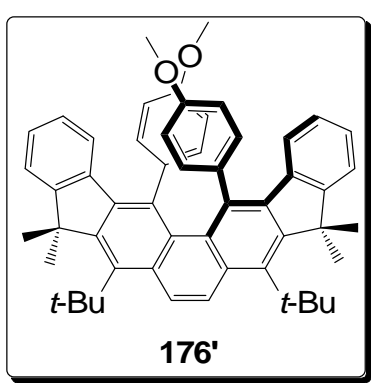

rac-176: $91 \%$

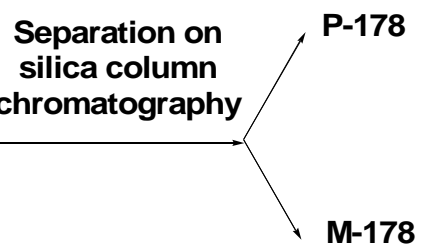

P-178 and M-178: 68\%

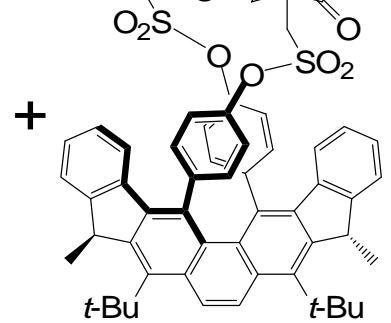

Scheme 48. Methylation of $\mathbf{1 6 3}$ and resolution of 177.

The camphorsulfonate $\mathbf{1 7 8}$ was synthesized from $\mathbf{1 7 7}$ and then resolved with the same method shown in Scheme 47. As shown in Figure 19, the well resolved ${ }^{1} \mathrm{H}$ NMR signals of the $\mathrm{AB}$ patterns between $\delta 3.8$ and 3.1, attributable to the hydrogens adjacent to the sulfonyl group. The two aromatic hydrogens closest to the phenolic substituents at $\delta 6.3$ are partly overlapped.

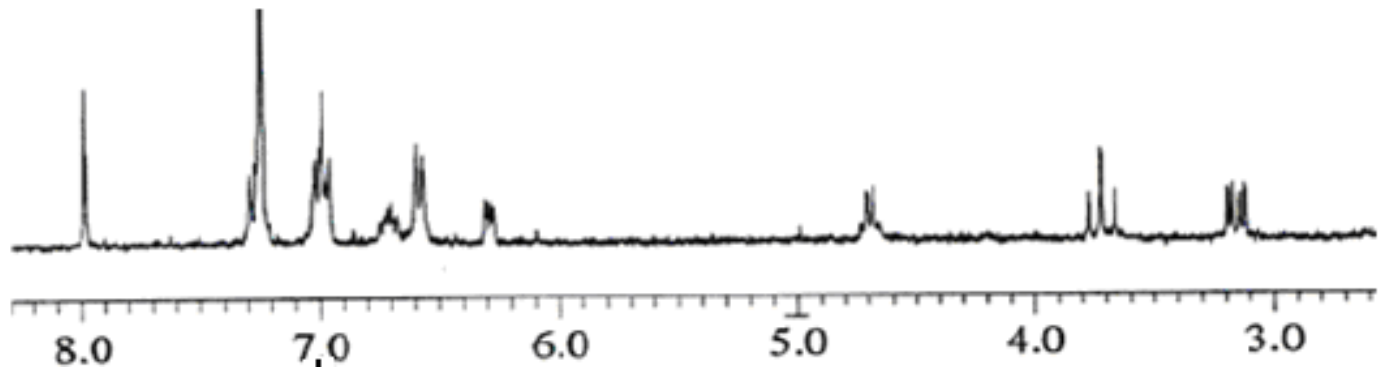

(a) Methylated diastereomers derivatized with camphorsulfonyl group 


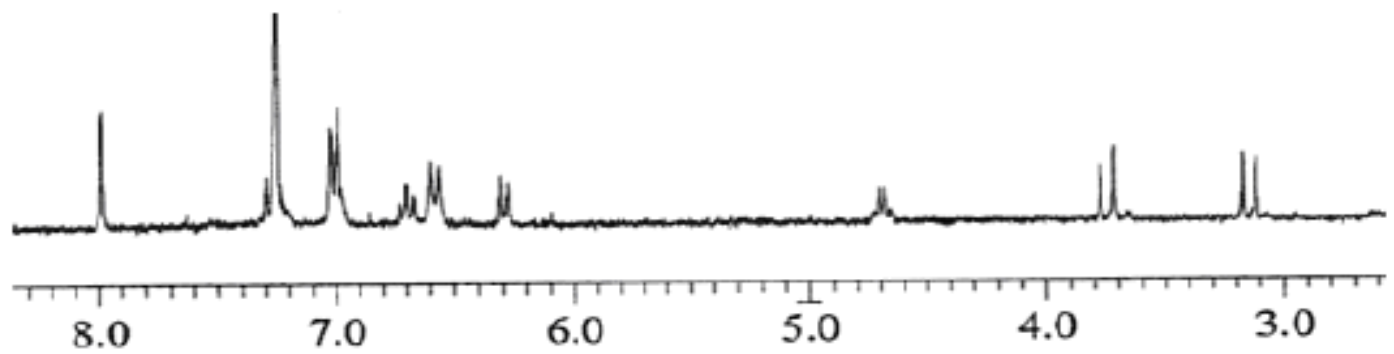

(b) Separated methylated diastereomer

Figure 19. ${ }^{1} \mathrm{H}$ NMR spectra of camphorsulfonates 178.

The camphorsulfonyl moiety in $\mathbf{1 7 5}$ was readily removed by treatment with aqueous sodium hydroxide solution at $40{ }^{\circ} \mathrm{C}$ to regenerate the optically pure parent $\mathbf{P}$ - and $\mathbf{M}$ 164. P-164 and M-164 enantiomers exhibited large specific rotations of $[\alpha]^{25}=-904 \pm 6^{\circ}(c 1$, $\left.\mathrm{CH}_{2} \mathrm{Cl}_{2}\right)$ and $[\alpha]^{25}=+904 \pm 6^{\circ}\left(c 1, \mathrm{CH}_{2} \mathrm{Cl}_{2}\right)$.
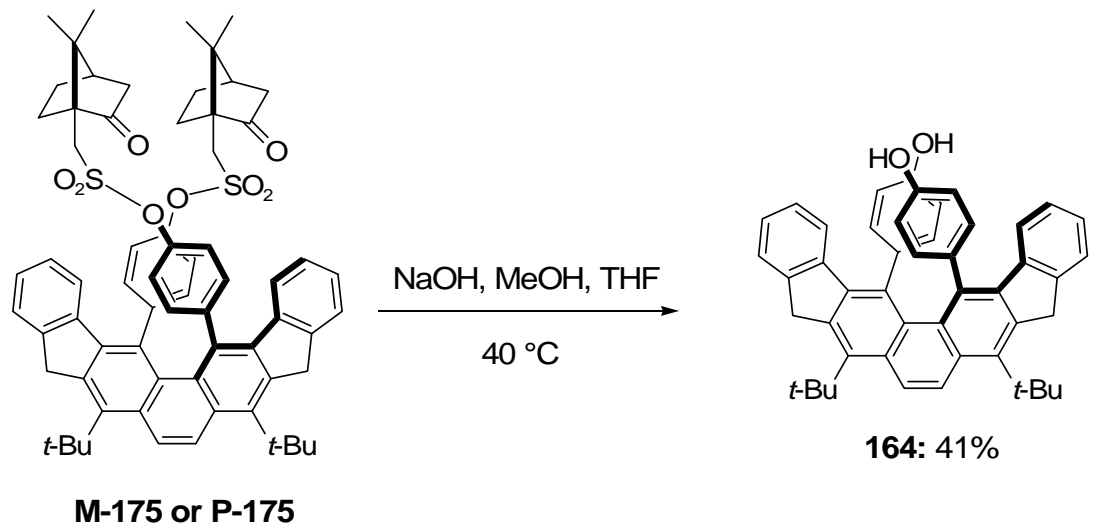

Scheme 49. Hydrolysis of bis-camphor sulfonate 175.

\subsection{Low stability of diphenol-substituted phenanthrene}

The methylated product $\mathbf{1 7 6}$ was unstable under acidic conditions. The product decomposed on standing and the NMR spectrum showed such decomposition. Several small peaks, marked with arrows, were observed adjacent to the original peaks. These small peaks became bigger and bigger and finally only broad peaks were observed. 


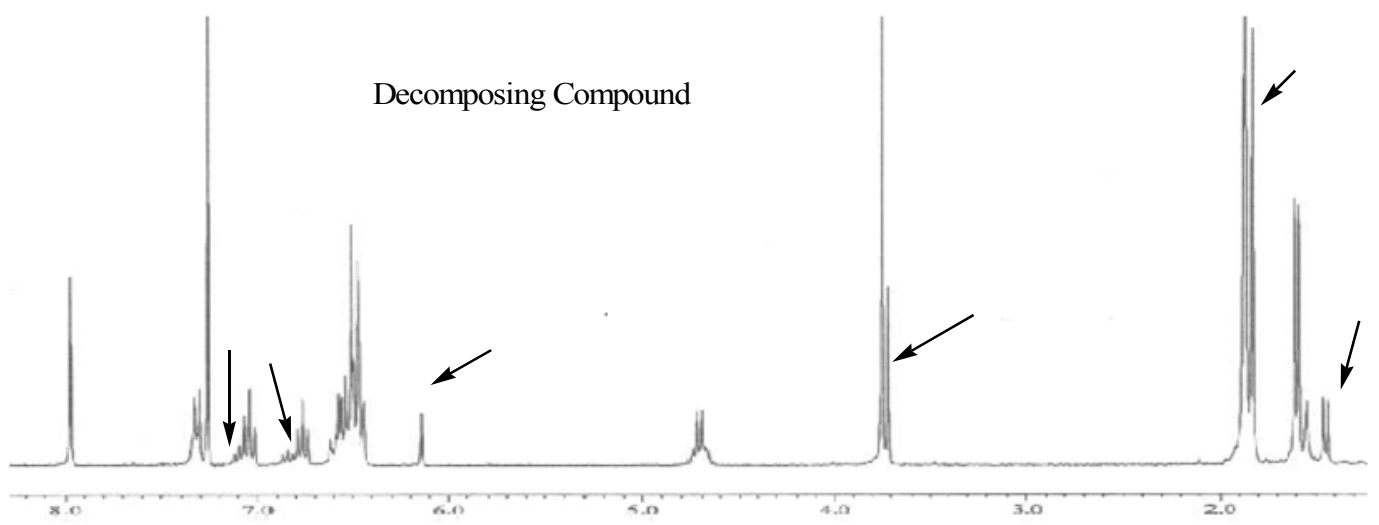

Figure 20. NMR spectrum of decomposition of compound 176.

Dr. Yonghong Yang of our group observed that the tert-butyl groups were easily removed from the aromatic ring via retro Fridel-Craft alkylation reaction on exposure to proton or a Lewis acid. ${ }^{100}$ This might be one of the reasons for the phenolic product to be unstable, when exposed to even mild acidic conditions.

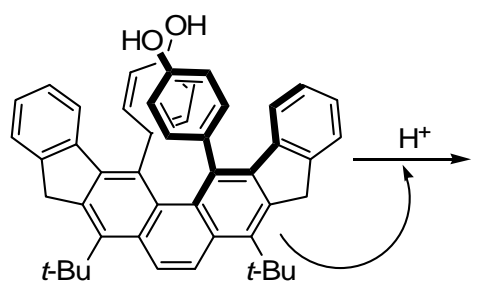

164

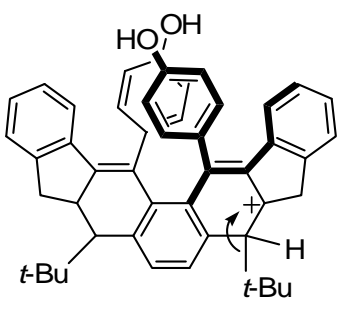

$t-\mathrm{Bu}$
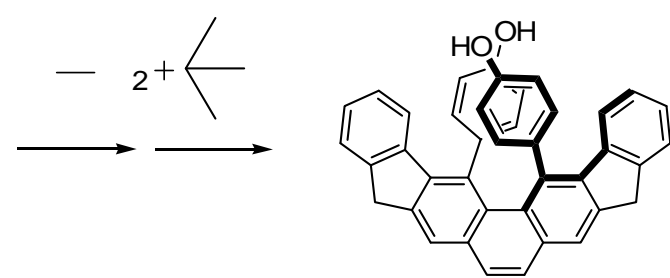

179

Scheme 50. Cleavage of the tert-butyl group under acidic condition.

The other potential origin of low stability might come from protonation followed by a facile intramolecular electrophilic aromatic substitution reaction, which was observed for the transformation of 1-phenylbenzo[a]anthracene to dibenzo[a,l]pyrene (180). ${ }^{101}$<smiles>c1ccc(-c2cccc3ccc4cc5ccccc5cc4c23)cc1</smiles>

180

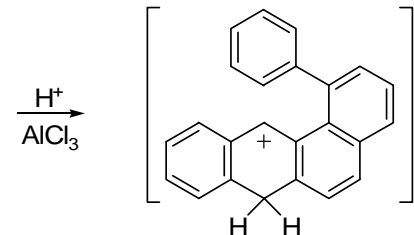

$\mathrm{H} \mathrm{H}$<smiles></smiles>

181: $66 \%$

Scheme 51. Intramolecular electrophilic aromatic substitution. 
Dr. Yonghong Yang of our group also observed a similar transformation from $\mathbf{1 8 2}$ to 187, which proceeded via protonation followed by an intramolecular electrophilic aromatic substitution reaction involving the phenyl substituent to form $\mathbf{1 8 5}$, followed by deprotonation to give $\mathbf{1 8 6} .^{100}$
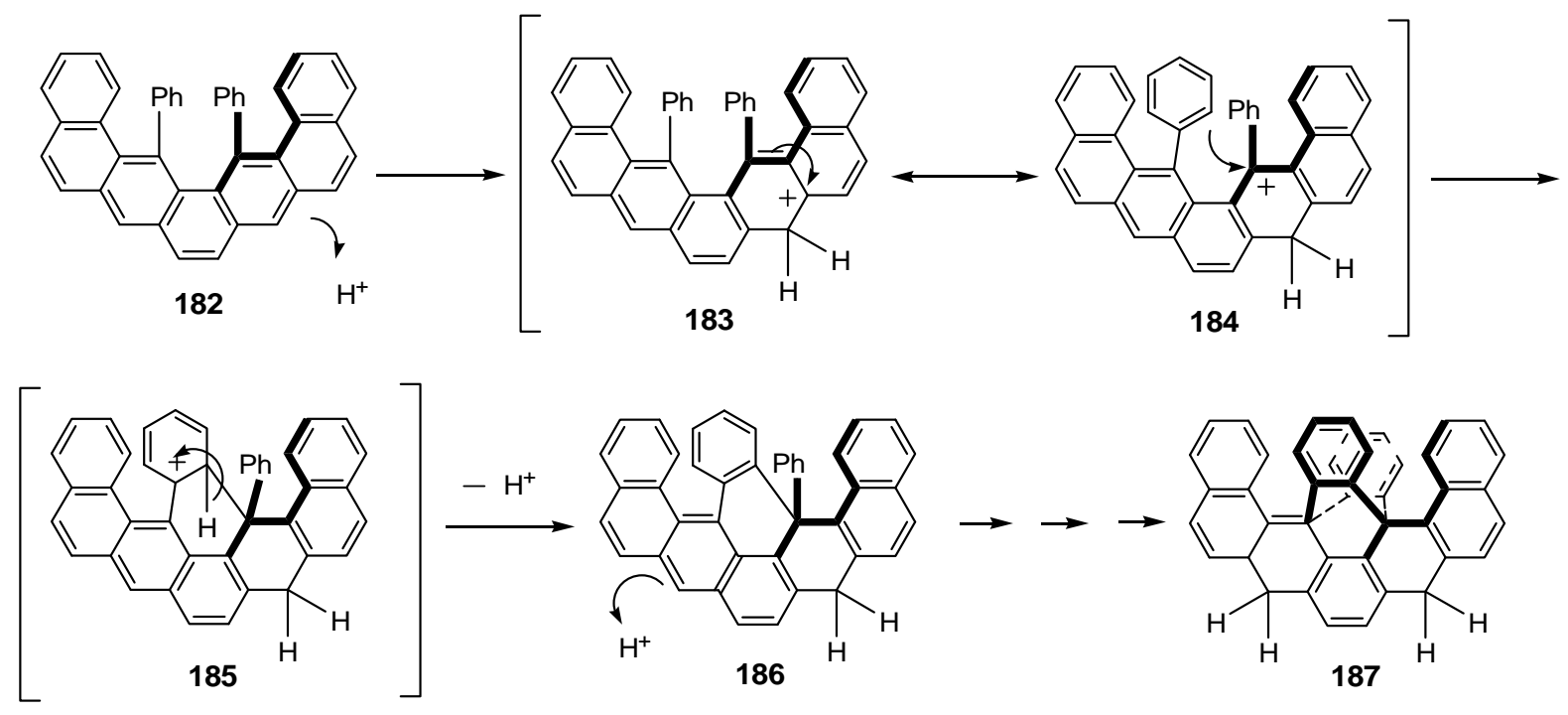

Scheme 52. Dr. Yang's observation of protonation and intramolecular electrophilic aromatic substitution reaction.

In my case, the hydroxyl groups on the phenolic substituents could stabilize the carbocation intermediate and thus greatly facilitates the intramolecular electrophilic aromatic substitution reaction.
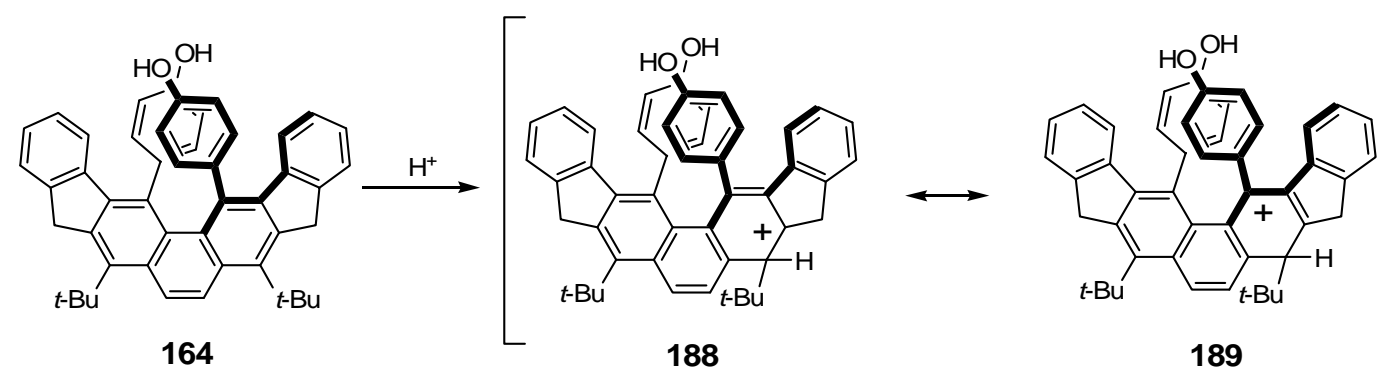

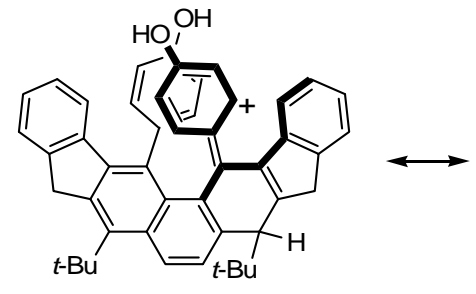

190

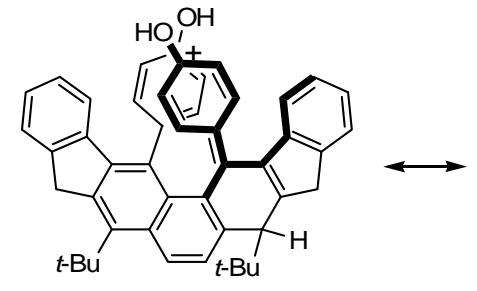

191

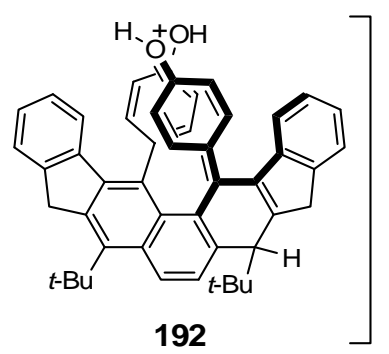

192

Scheme 53. Intramolecular electrophilic aromatic substitution and resonance structures. 
Various unidentified factors might contribute to the decomposition of the cyclized products. Even crystallized compounds of high purity decomposed gradually even under an inert atmosphere at below $0{ }^{\circ} \mathrm{C}$.

\section{4. $\mathrm{C}_{2}$-Symmetrical homo-bi-dentate 4,5-diarylphenanthrene ligands containing ortho- and meta-substituents}

A series of products bearing ortho- or meta-phenolic group have also been synthesized using the same synthetic strategy, beginning with the Sonogashira coupling between 3-ethynylanisole (192) or 2-ethynylanisole, and diiodide 160, as shown in Schemes 54 and 55.

The meta-anisole product $\mathbf{1 9 5}$ also decomposed on standing and totally decomposed on attempts for demethylation by treatment with boron tribromide. The dimethylated meta-anisole product of $\mathbf{1 9 6}$ also slowly decomposed on standing. Methylation of the benzofluorene moiety appears to slow down the rate of decomposition as observed in the para-anisole product.

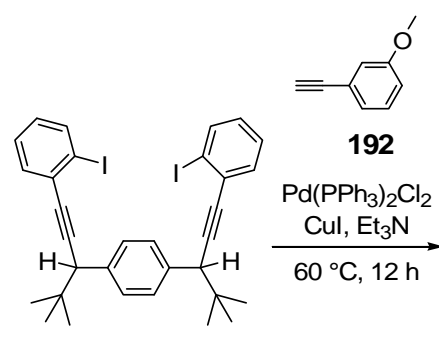

160

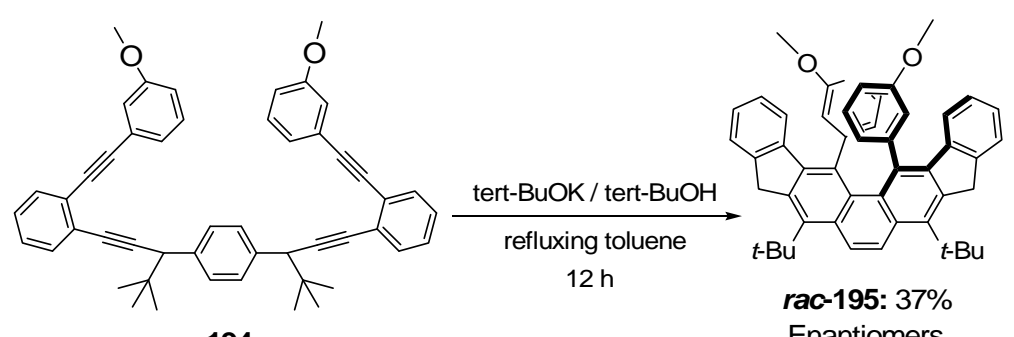

194 Enantiomers

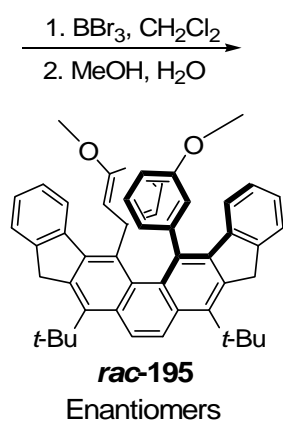

Decomposed

1. tert-BuOK / tert-BuOH

2. Mel

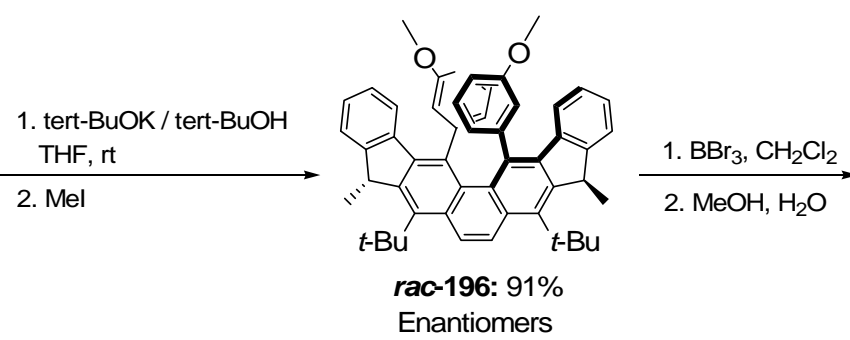

Enantiomers

Scheme 54. Synthesis of 4,5-diarylphenanthrene containing meta-anisole moieties 196. 
Interestingly, the ortho-anisole product $\mathbf{1 9 8}$ was obtained as a mixture of three isomers not separable by flash column chromatography. The $t$-butyl groups of the mixture gave three peaks at around $\delta 1.8$ on the ${ }^{1} \mathrm{H}$ NMR spectrum with a ratio of $55: 38: 7$. Presumably, the restricted rotation of the anisole groups is responsible for giving rises to these rotational isomers.

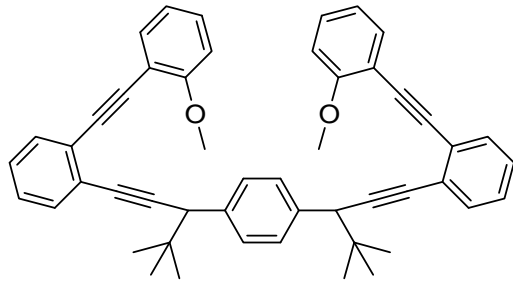

197

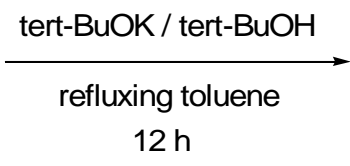

$12 \mathrm{~h}$

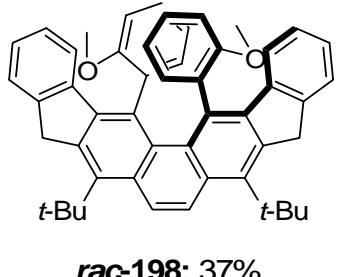

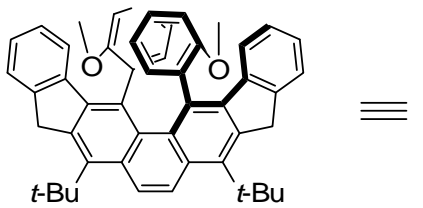

198

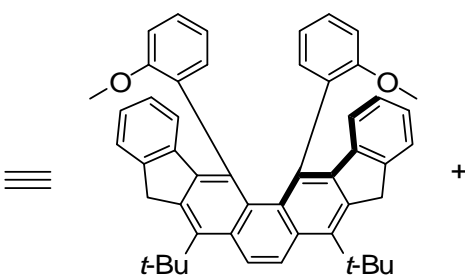

$198 \mathrm{a}$

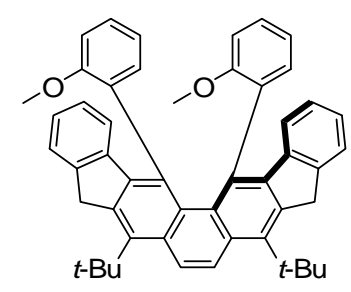

$198 b$

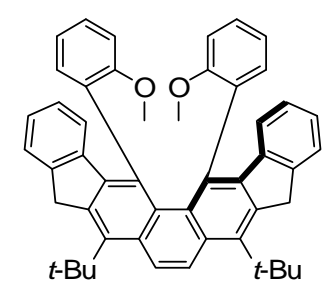

$198 \mathrm{c}$

Scheme 55. Synthesis of 4,5-diortho-anisolic phenanthrene 198.

The methylene hydrogen signals at $\delta 4.00-4.45$ also show three sets of $A B$ quartets with the same germinal coupling constant of $21.0 \mathrm{~Hz}$.

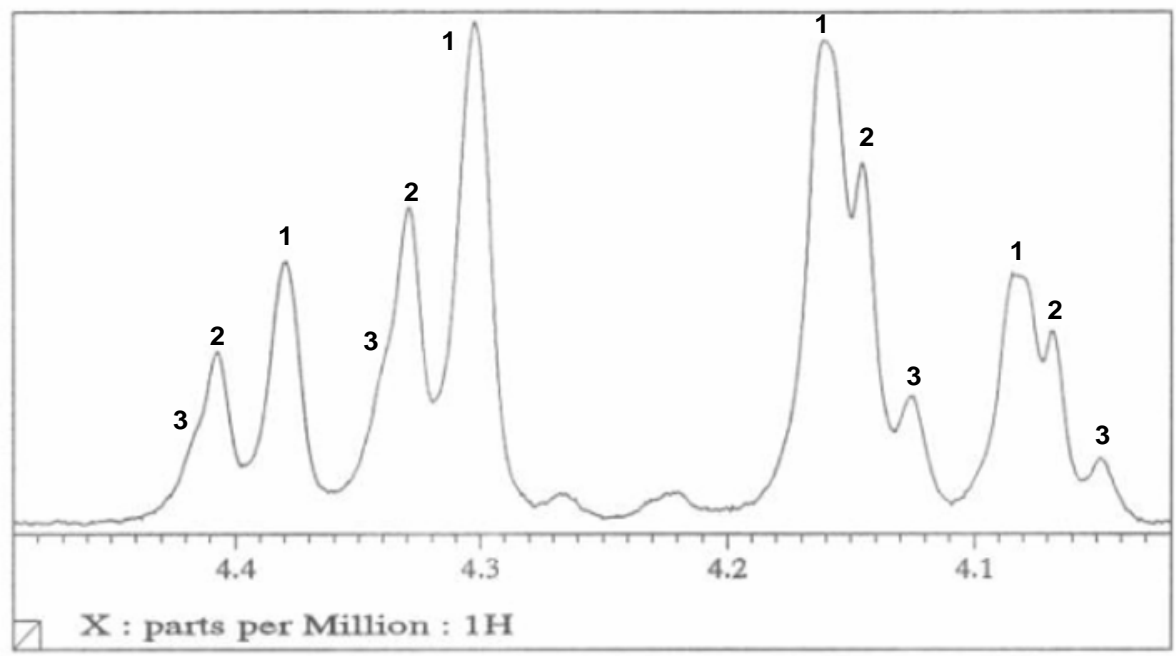

Figure 21. ${ }^{1} \mathrm{H}$ NMR Spectrum of three sets of $\mathrm{AB}$ quartet from methylene hydrogens of 198. 


\subsection{Para-aniline substituted $\mathrm{C}_{2}$-symmetrical homo-bi-dentate product}

Aniline groups were also employed to produce helical 4,5-diarylphenanthrene derivative 201 resembling BINAM, which could show high stability at elevated temperatures and under strong basic and acidic conditions. The palladium-catalyzed (Sonogashira) coupling of terminal acetylene 199 with diaryl iodide 160 afforded 200. The cascade cyclization reactions of 200 produced 4,5-di(4-aminophenyl)phenanthrene 201. The resulting enantiomers could be separated on column chromatography by converting 201 to the corresponding diastereomeric sulfonamides $\mathbf{2 0 2}$ by treatment with camphor sulfonyl chloride and triethylamine. The solvent system used for the separation of diastereomers on silica gel chromatography was $40 \%$ diethyl ether in hexanes.

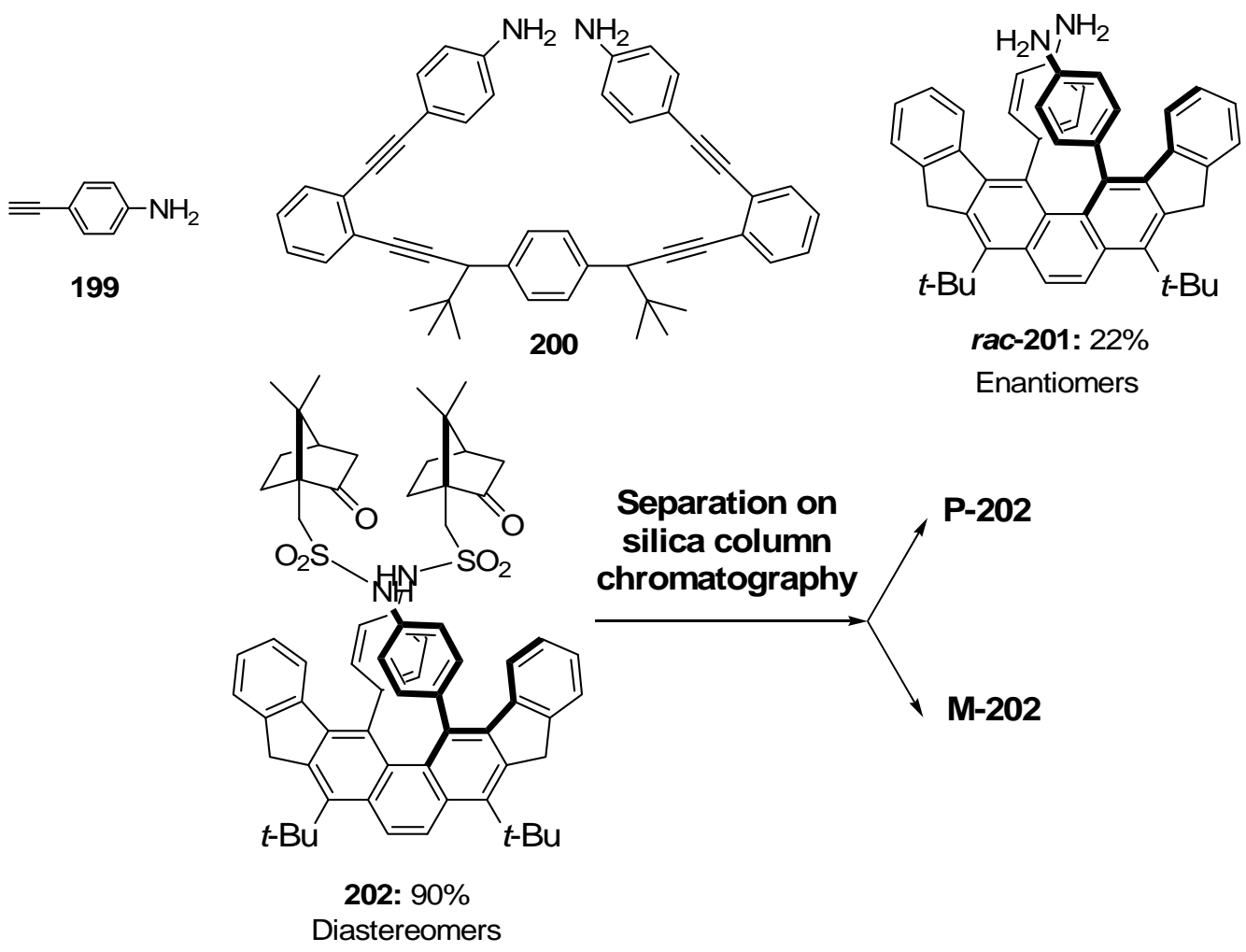

Scheme 56. Synthesis of a ligand containing 4-aminophenyl moiety.

Interestingly, compared to para-anisole-substituted phenanthrene, the diastereomeric sulfonamides 202 showed different chemical shift patterns especially in the aromatic region and between $\delta 4.5$ and 3.5 of methylene hydrogens (Figure 22). One set of AB pattern 
attributable to the methylene hydrogens, occurred as a doublet at $\delta 4.38$ (Figure 22b) $(J=21$ $\mathrm{Hz})$ and 4.45 (Figure 22c) $(J=21 \mathrm{~Hz})$, whereas the other set occurred as a doblet at $\delta 4.12$ (Figure 22b) $(J=21.0 \mathrm{~Hz})$ and as an overlapping signal at $\delta 4.20-4.09$ (Figure 22c).

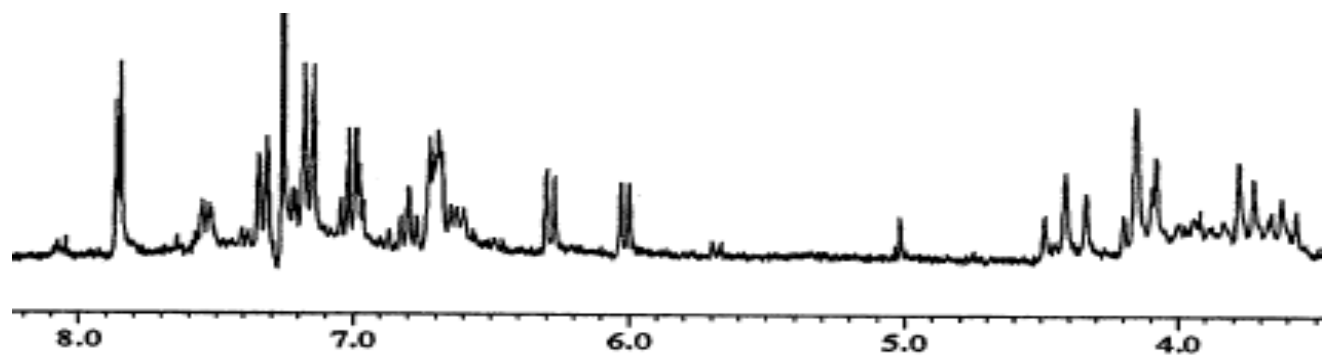

(a) Diastereomeric sulfonamides

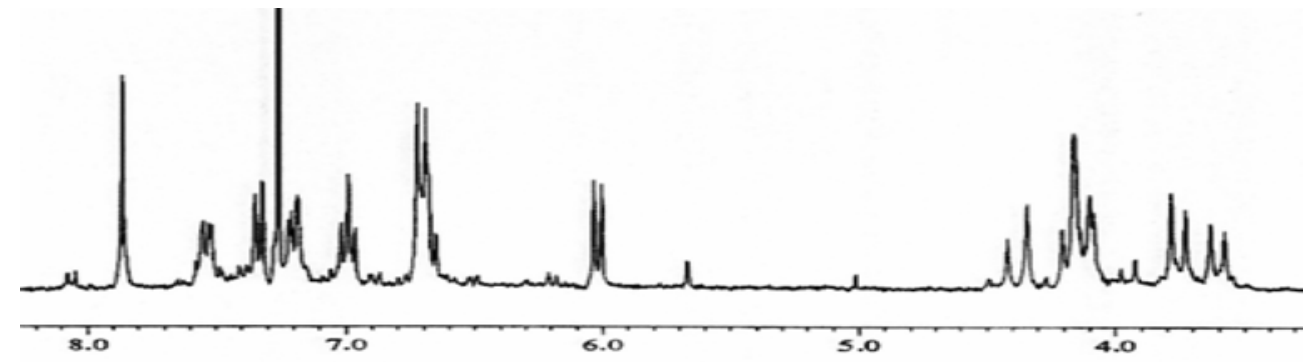

(b) Separated diastereomeric sulfonamide

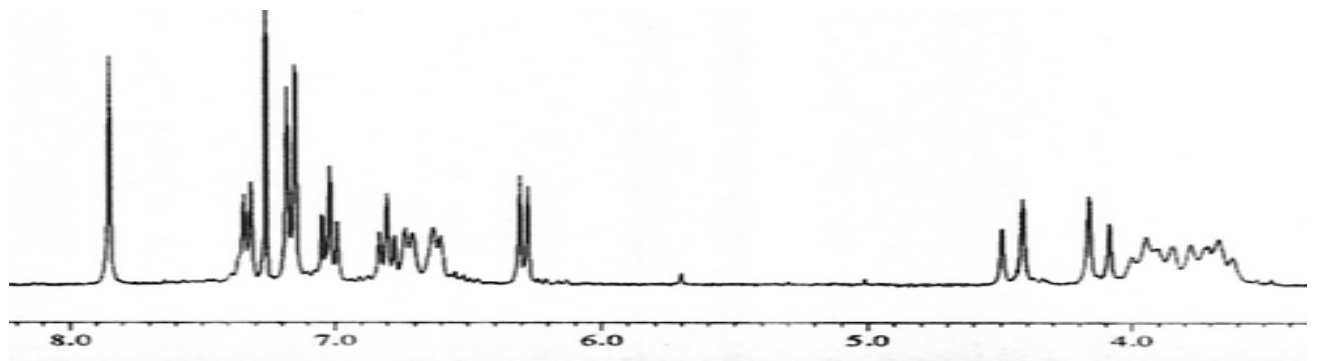

(c) Separated diastereomeric sulfonamide

Figure 22. ${ }^{1} \mathrm{H}$ NMR spectra of diastereomeric sulfonamide.

After chromatographic separation, attempts were made to remove the camphorsulfonyl groups in $\mathbf{2 0 2}$ to produce the optically pure M- or P-enantiomer. A few methods were employed to remove the camphorsulfonyl group from very stable sulfonamide. ${ }^{102}$ Several reports in the literature described detosylation from the arylation products using samarium iodide. However, this method failed in our case. ${ }^{102}$ Treatment of sulfonamide 202 with aqueous sodium hydroxide in refluxing THF for $12 \mathrm{~h}$ showed no 
reaction. All attempts to remove the sulfonyl group from sulfonamide $\mathbf{2 0 2}$ failed.

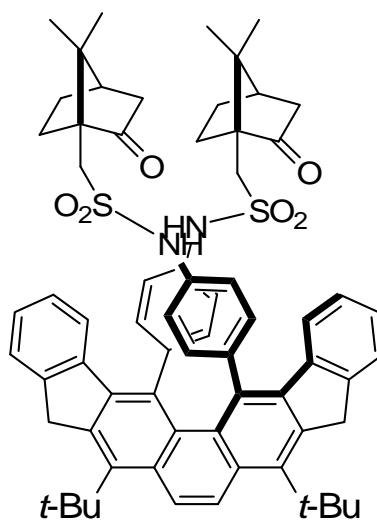

$\mathrm{NaOH}, \mathrm{MeOH}, \mathrm{THF}$

reflux, overnight

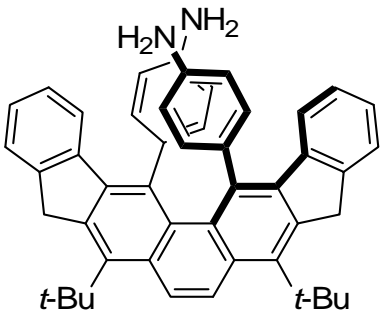

201

202

Scheme 57. Hydrolysis of biscamphor sulfonamide 202.

\section{Conclusion}

The synthetic strategy for the twisted polycyclic aromatic hydrocarbon bearing 4,5-diarylphenanthrene moiety was successfully adopted for the synthesis of $\mathrm{C}_{2}$-symmetrical homo-bi-dentate ligands. Demethylation of cyclization product followed by derivatization with camphor sulfonyl group converted the racemic mixture of 4,5-di(4-methoxyphenyl)phenanthrenes to the corresponding diastereomers, which could be separated on silica gel column chromatography. However, the resolved diphenolic compound could not be used as a ligand due to its low stability. A 4,5-diarylphenanthrene derivative containing 4-aminophenyl substituents were likewise synthesized and its camphorsulfonamide derivatives were separated by silica gel column chromatography. 


\section{Part IV}

\section{Attempted Synthesis of an Indeno-Fused Corannulene via Cascade Cyclizations of Benzannulated Enyne-Allenes}

\section{Introduction}

Polycyclic aromatic hydrocarbons (PAHs) generated from the cyclization of benzannulated enyne-allenes provided many opportunities for various synthetic applications. Recently, bowl-shaped compound, pentaindenocorannulene $\left(\mathrm{C}_{50} \mathrm{H}_{20}\right) 203$ was synthesized via non-pyrolytic method by the Scott's group. ${ }^{84 \mathrm{~d}}$ We are interested in the synthesis of $\mathbf{2 0 4}$ and $\mathbf{2 0 5}$ using the cascade cyclization reaction of benzannulated enyne-allenes.

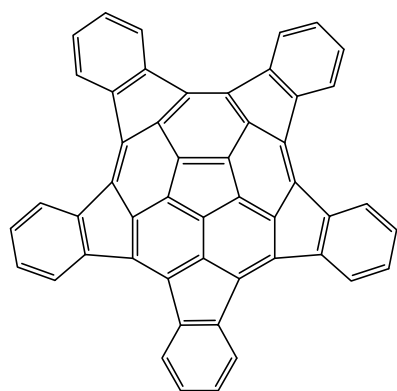

203

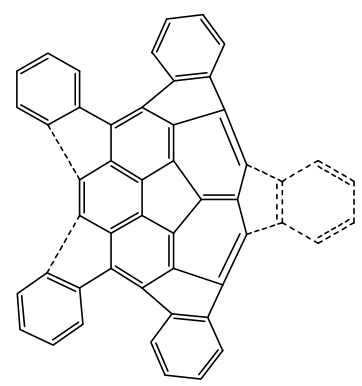

204

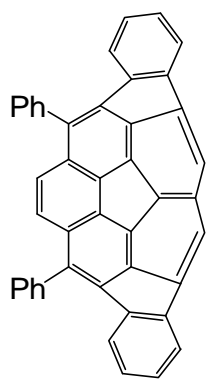

205

Scheme 58. The structures of pentaindenocorannulene and PAHs 204 and 205.

The synthetic sequence for bowl-shaped compounds mentioned in Part II was also employed for this investigation. In an earlier work of our research group, Dr. Yonghong Yang firstly reported the synthesis of PAHs via enyne-allenes derived from an Ireland-Claisen rearrangement. ${ }^{24}$ Dr. Yang's approach is outlined in Scheme 59. The propargylic acetate 207 was obtained by condensation between the lithium acetylide $\mathbf{1 2 4}$ and 9-fluorenone (206). Treatment of 207 with LDA, followed by trapping with tert-butyldimethylsilyl chloride (TBDMSCl) then furnished the silyl ketene acetal. A subsequent Ireland-Claisen rearrangement then furnished the corresponding benzannulated enyne-allene. A subsequent 
Schmittel cyclization then led to the silyl ester 212, in which hydrolysis produced carboxylic acid 213 in $57 \%$ yield. $^{24}$

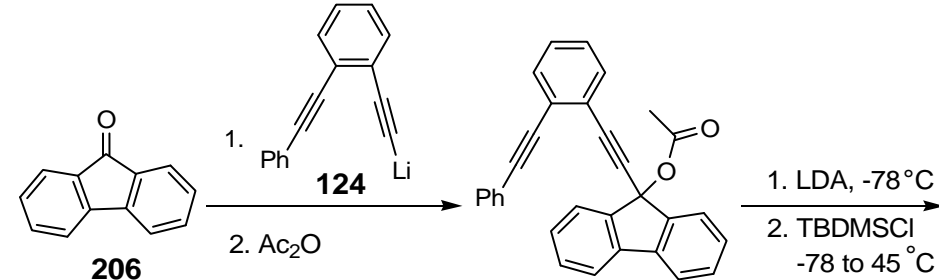

207: $83 \%$

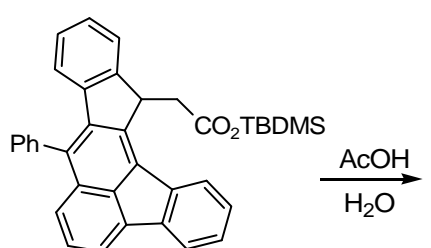

212

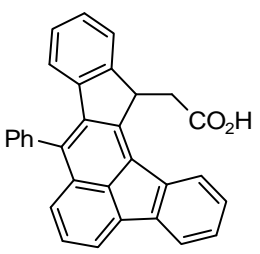

213: $57 \%$

Scheme 59. Synthesis of a PAH containing carboxylic acid via Ireland-Claisen rearrangement.

Conversion of $\mathbf{2 1 3}$ to the corresponding acid chloride with thionyl chloride followed by an intramolecular acylation reaction promoted by aluminum chloride produced the polycyclic aromatic ketone $\mathbf{2 1 4}$ in $88 \%$ yield.

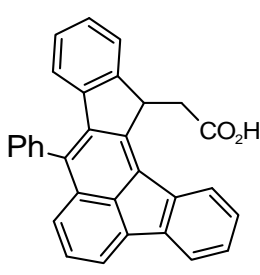

213

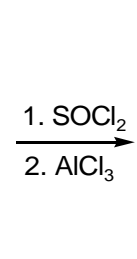

$\underset{\mathrm{AlCl}_{3}}{\stackrel{\mathrm{SOCl}_{2}}{\longrightarrow}}$

$\mathrm{Ph}$

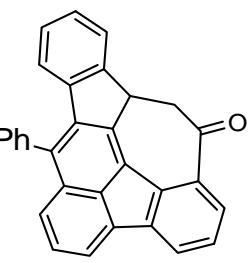

214: $88 \%$

Scheme 60. Intramolecular acylation with thionyl chloride and aluminum chloride.

Dr. Han of our group also tried to synthesize a precursor of tetraindenocorannulene via cascade cyclization reaction of enyne-allenes. It was invisioned that ketone 215 could be used as a potential precursor of $\mathbf{2 1 6}$ leading to $\mathbf{2 1 7}$ containing a corannulene unit.

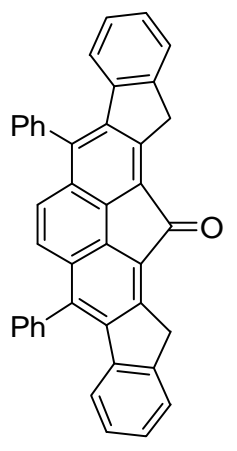

215

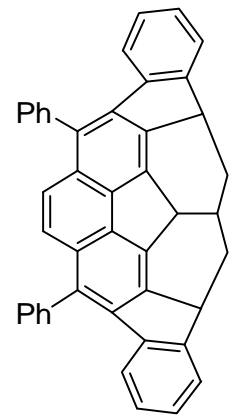

216

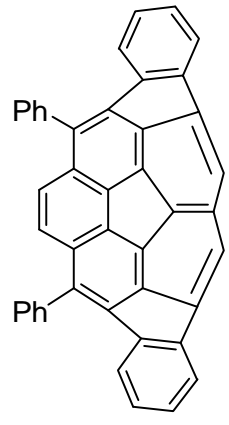

217

Scheme 61. Han's approach for the synthesis of a PAH containing a corannulene unit. 
Han's approach is outlined in Scheme 62. Condensation between diketone 218 and 2 equiv of 219 led to propargylic diols 220 which were treated with thionyl chloride to give the diindeno-fused $4 H$-cyclopenta[def]phenanthrene 215. The reaction involved two cascade cyclization sequences. The reduction of the crude product with tributyltin hydride gives $\mathbf{2 1 5}$ in $44 \%$ overall yield from the trans-diol 220a. It is worth noting that four new rings were constructed in a single operation at room temperature, making the pathway is very efficient route for the construction of polycyclic aromatic structures. Ketone 215 was then treated with dimethyl malonate in the presence of $\mathrm{TiCl}_{4}$ and pyridine to give diester 221 in $51 \%$ yield. The diester was reduced with $\mathrm{LiEt}_{3} \mathrm{BH}$ and then converted to dichloride $\mathbf{2 2 3}$ with thionyl chloride in 45\% yield. However, attempts for ring closure to give 216 were unsuccessful.

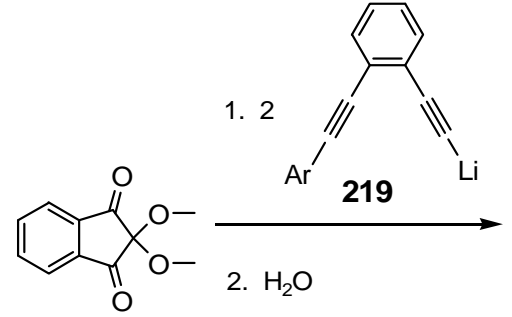

218

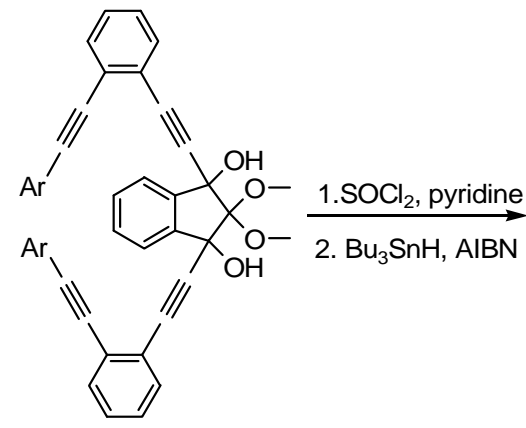

220a: trans-diol, $64 \%$

220b: cis-diol, $21 \%$

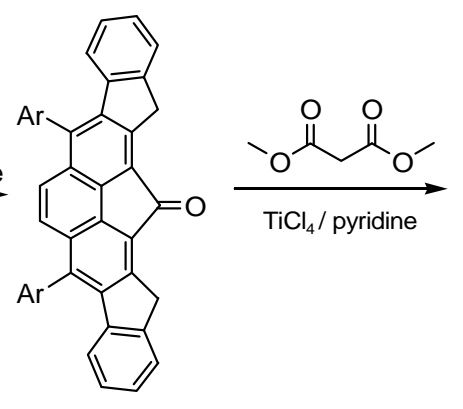

215: $44 \%$

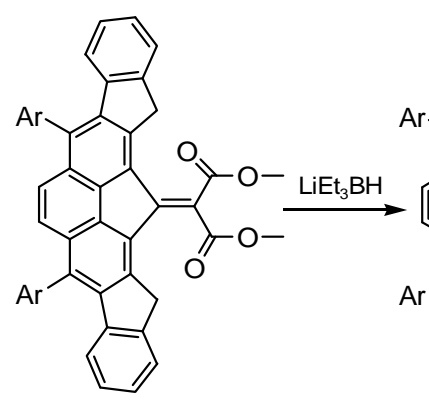

221: $51 \%$

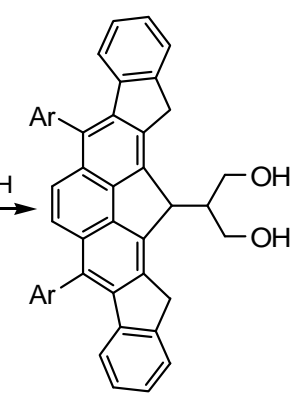

222
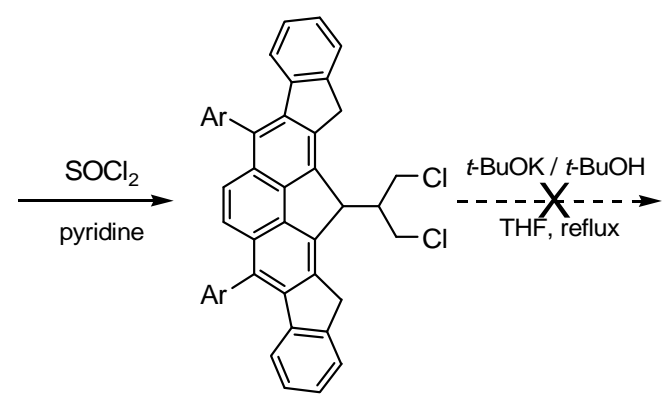

223: $45 \%$

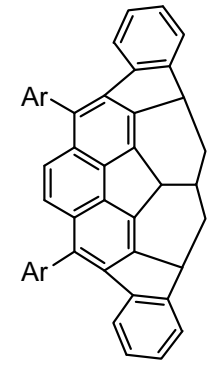

216

Scheme 62. Synthesis of $4 H$-cyclopenta[def]phenanthrene.

Previous research of Ms. Parbin of our group demonstrated that small polycyclic aromatic hydrocarbons could be synthesized via simple intramolecular $\mathrm{S}_{\mathrm{N}} 2$ reactions. In her work, condensation of $\mathbf{2 2 4}$ with the lithium acetylide $\mathbf{1 2 4}$ furnished the propargylic alcohol 
225 in 75\% yield. Reduction of propargylic alcohol 225 with triethylsilane in the presence of trifluoroacetic acid produced hydrocarbon $\mathbf{2 2 6}$ in $80 \%$ yield. Treatment of $\mathbf{2 2 6}$ with potassium $t$-butoxide in refluxing toluene produced alkene 227 in a single operation. ${ }^{104}$ Hydroboration of alkene 226 with disiamylborane followed by iodination in the presence of sodium hydroxide led to alkyl iodide $\mathbf{2 2 8}$ in $65 \%$ yield. Treatment of alkyl iodide $\mathbf{2 2 8}$ with potassium $t$-butoxide in THF at $40{ }^{\circ} \mathrm{C}$ furnished the polycyclic aromatic hydrocarbon 229 in $60 \%$ yield. Parbin's approach involved incorporating less strained $\mathrm{sp}^{3}$-hybridized carbons into the PAH skeleton.

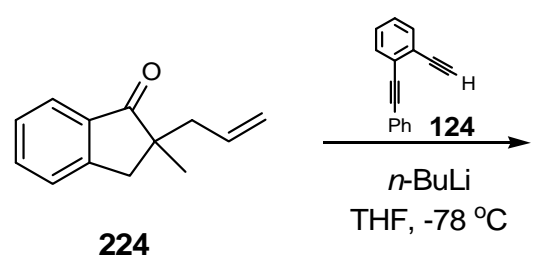

224

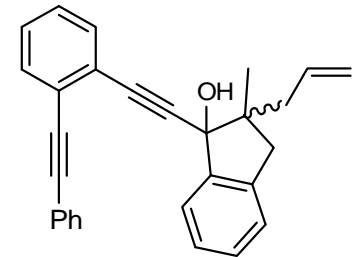

225: $75 \%$

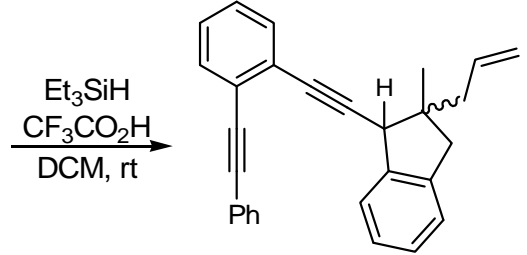

226: $80 \%$

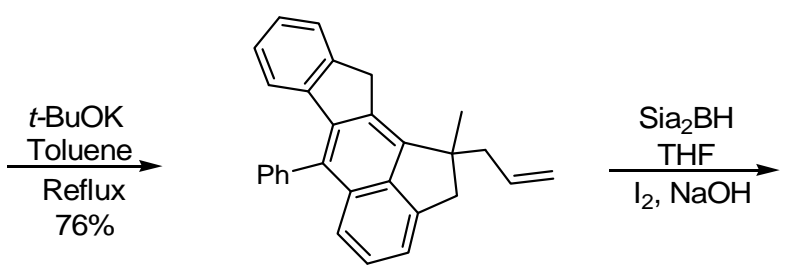

227

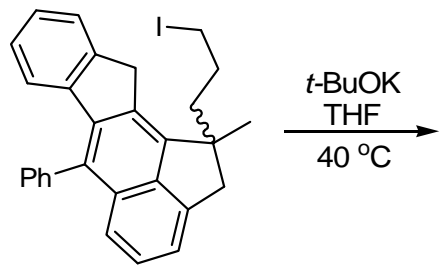

228: $65 \%$

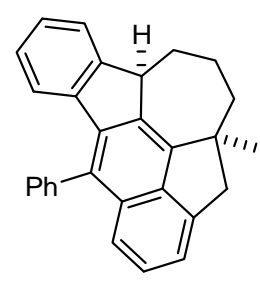

229: $60 \%$

Scheme 63. Parbin's approach to synthesize all fused ring.

\section{Research objective}

Based on our previous discovery about the synthesis of double-cyclized hydrocarbon via $\mathrm{S}_{\mathrm{N}} \mathrm{i}$ ' reaction promoted by thionyl chloride, we were interested in further exploring its application for the synthesis of fused ring system. We were also interested in exploring the synthesis of corannulene derivative $\mathbf{2 3 0}$ by introducing $\mathrm{sp}^{3}$-hybridized carbons into its skeleton. We envisioned that tandem Knoevenagel/hydrogenation reaction could furnish valuable diketones leading to potential precursors for pentaindenocorannulene (203) or tetraindenocorannulene. 


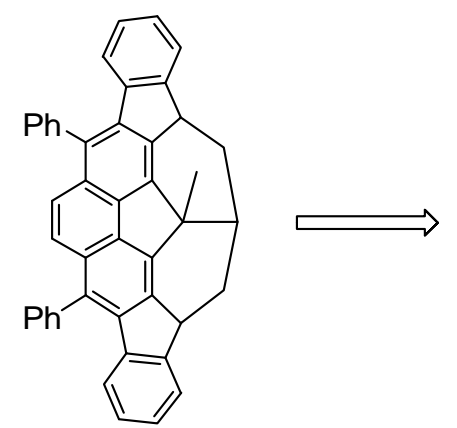

230

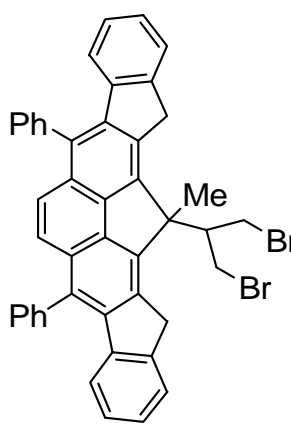

$\rightleftarrows$<smiles>COCC(COC)C12C(=O)c3ccccc3C(=O)C1(C)C2=O</smiles>

232

Scheme 64. Retrosynthetic sequence for the synthesis of corannulene derivative 230.

\section{Results and Discussion}

\subsection{Synthesis of all fused polycyclic aromatic hydrocarbons containing corannulene moiety}

A synthetic design leading to bowl-shaped PAH is outlined in Scheme 65. The synthetic sequence began with $\mathbf{2 3 3}$ for tandem Knoevenagel condensation and Hydrogenation. The amino acid L-proline catalyzed-Knoevenagel condensation of 1,3-dimethoxyacetone (233) with 1,3-indanedinone (238) to furnish the olefin, which was reduced with Hantzsch ester $^{105 \mathrm{a}}$ to produce the hydrogenated product 234 in $82 \%$ yield. ${ }^{105 \mathrm{~b}}$ Methylation was carried out with potassium $t$-butoxide and iodomethane to give the methylated 1,3-indandione 232 in $78 \%$ yield. Condensation with the lithium acetylide followed by cyclization with thionyl chloride and reduction with tributyltin hydride then furnished 236 in $40 \%$ overall yield. Compound 236 was converted to diol 237 with boron tribromide. Subsequent bromination with triphenylphosphine and carbon tetrabromide gave the requisite dibromide $\mathbf{2 3 1}$. 


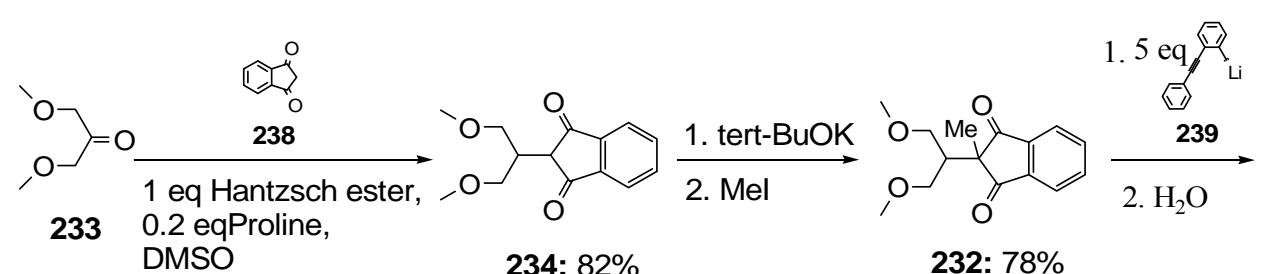

232: $78 \%$

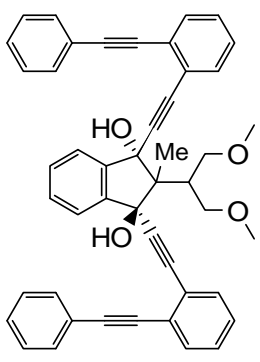

235: $93 \%$

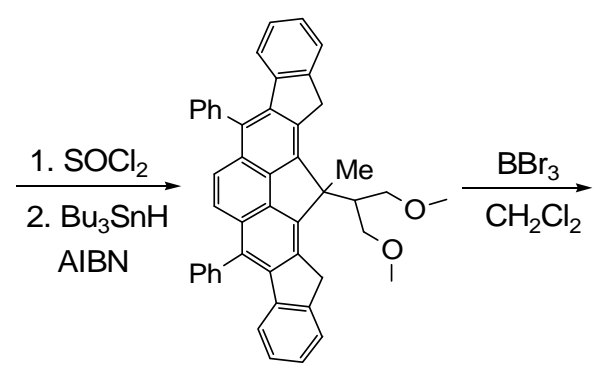

236: $40 \%$

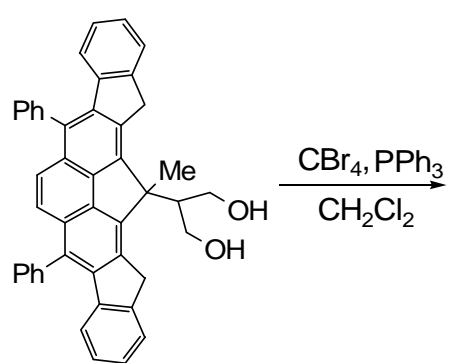

237: $60 \%$

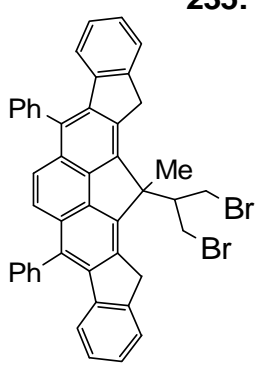

231: $52 \%$

Scheme 65. Synthesis of a precursor for a bowl-shaped compound bearing a corannulene moiety.

Attempts were made to try to promote the two intramolecular $\mathrm{S}_{\mathrm{N}} 2$ reactions to connect methylene carbons on five-membered rings with the carbons bearing the bromo substituents. A variety of conditions, including high temperature and more than 2 equiv of $t$-BuOK resulted in decomposition of 231. The crude NMR spectra showed only broad peaks, and the methylene hydrogens on the five-membered ring were partially oxidized to the keto group.

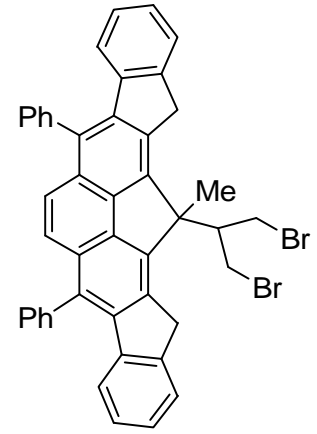

231
$\mathrm{t}-\mathrm{BuOK} / \mathrm{t}-\mathrm{BuOH}$ THF, reflux

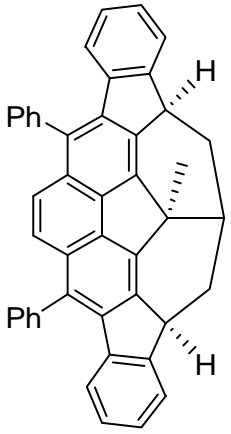

230

Scheme 66. Attempts to produce 230 containing a partially hydrogenated corannulene unit.

Although we applied a relatively milder condition, which was the use of 2.4 equiv of base and room temperature, to produce 230, any sign of the formation of the mono-closed 
product as well as double-closed product was not observed in the ring closing step. Attempt to use sodium hydride and catalytic amount of tert-butanol, was also unsuccessful.

\subsection{Fused polycyclic aromatic hydrocarbons via intramolecular alkylation}

A modified strategy was used to gain access to fused ring systems. In 241, one additional carbon was added to end of the two alkyl halide substituents, which could reduce the ring strain in the final ring-closed product. A retrosynthetic analysis is outlined in Scheme 67. The fused polycyclic aromatic hydrocarbon $\mathbf{2 4 0}$ could be synthesized from alkyl diiodide $\mathbf{2 4 1}$ via intramolecular alkylations. Alkyl diiodide 241 could be prepared from simple ring opening of pyran $\mathbf{2 4 2}$ with iodotrimethylsilane. ${ }^{106}$

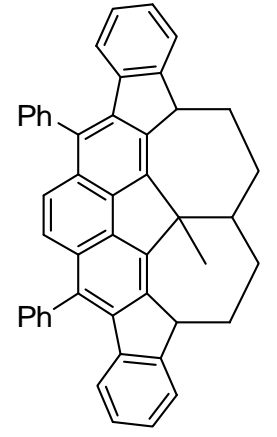

240

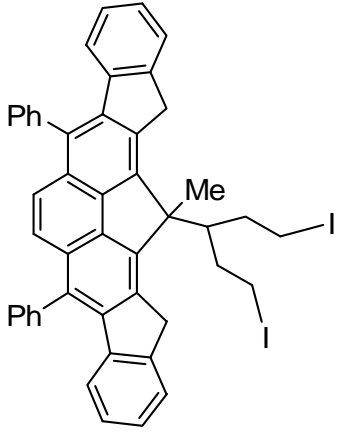

241

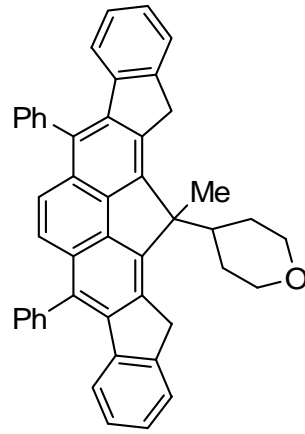

242

Scheme 67. The retro-synthetic analysis for the preparation of fused rings.

Diketone 245 was synthesized by the one-pot Knoevenagel/hydrogenation protocol. Following the synthesis of $\mathbf{2 4 5}$, the same procedure was employed for the synthesis of the trans-propargylic diol 246 for treatment with thionyl chloride and subsequent reduction with tributyltin hydride to give 242. In order to open up the pyran ring, an excess of trimethylsilyl iodide was used to furnish diioide $\mathbf{2 4 1}$ in $76 \%$ yield. ${ }^{106}$ 


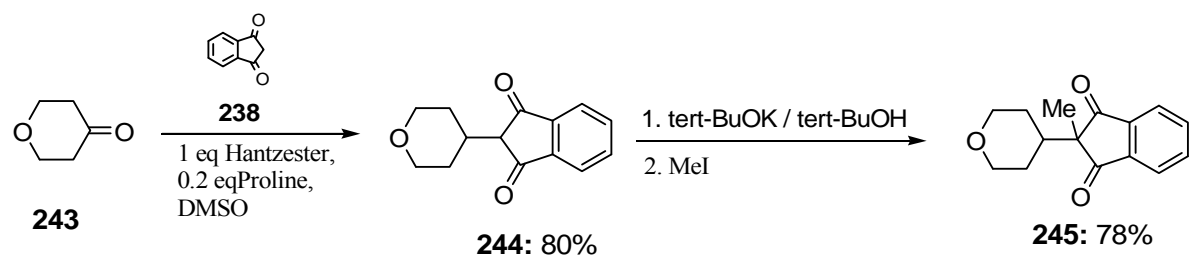

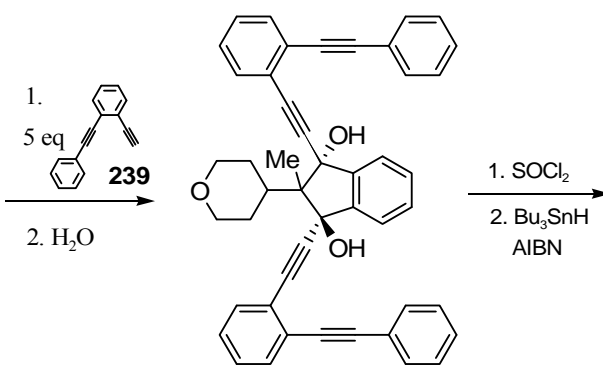

246: $89 \%$

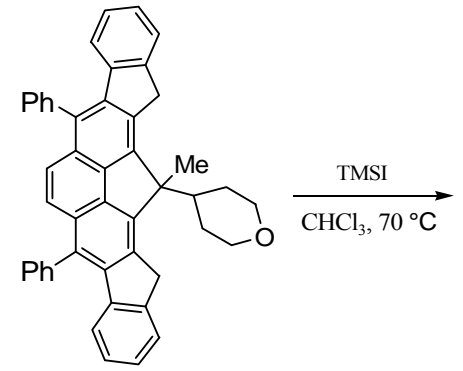

242: $40 \%$

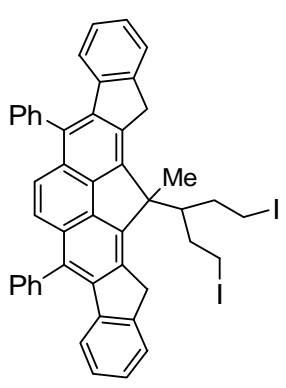

241: $76 \%$

Scheme 68. The synthetic sequence for diiodide 241.

Attempts to use potassium tert-butoxide for the intramolecular alkylation reactions were unsuccessful.

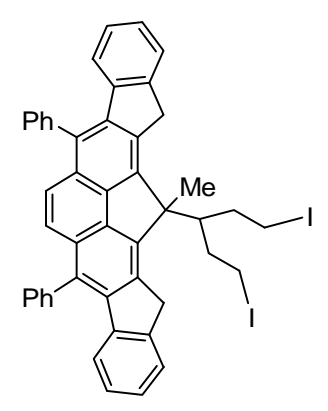

241

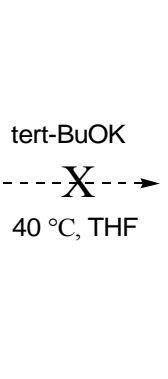

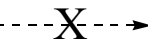

Scheme 69. First attempt to form all fused rings.

However, when 241 was treatd with LDA at room temperature, $8 \%$ of the fused polycyclic aromatic hydrocarbon $\mathbf{2 4 0}$ was obtained as a minor product along with the unexpected fused unsymmetrical 247 as a major product.

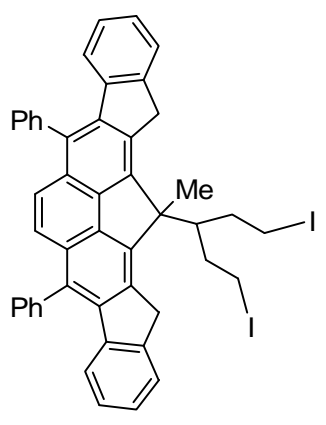

241

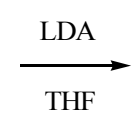

Scheme 70. Intramolecular alkylations promoted by LDA.

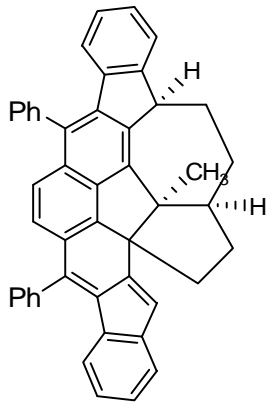

247: $44 \%$ 
The formation of the unexpected product 247 could arise from an intramolecular $\mathrm{S}_{\mathrm{N}} 2$ reaction involving a 5-exo-tet pathway of $\mathbf{2 4 9}$ according to the Baldwin's rule. It is worth noting that the 5-exo-tet pathway leading to $\mathbf{2 4 7}$ resulted in the loss of aromaticity of one of the benzene rings in $\mathbf{2 4 8}$.

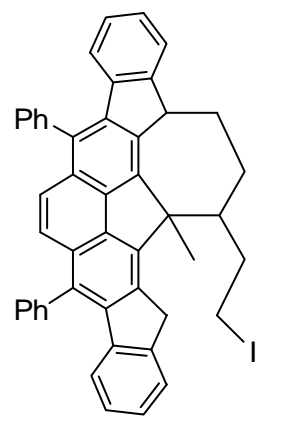

248

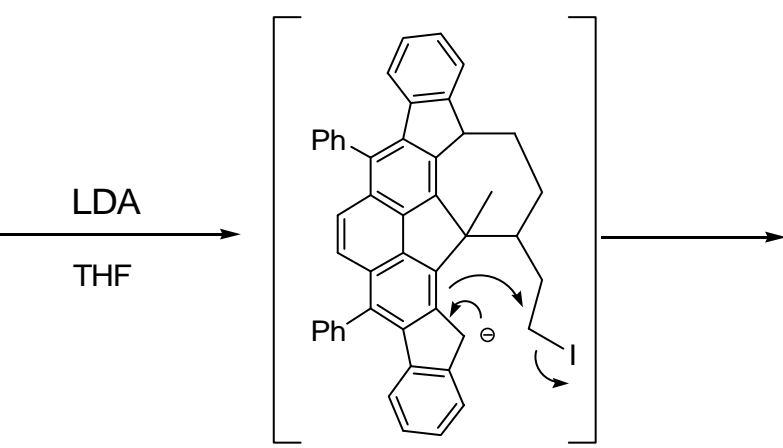

249

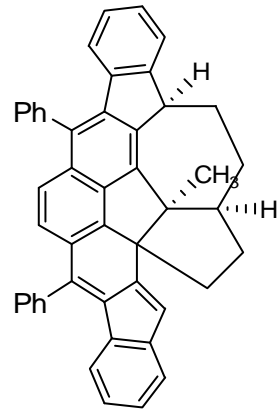

247

Scheme71. Mechanism for the major product 247.

Although the products $\mathbf{2 4 0}$ and $\mathbf{2 4 7}$ could not be separated by flash column chromatography, the ${ }^{1} \mathrm{H}$ NMR spectrum of 247 in $\mathrm{CDCl}_{3}$ using 1D TOCSY technique revealed the presence of the minor product $\mathbf{2 4 0}$ in $8 \%$ yield by NMR integration.

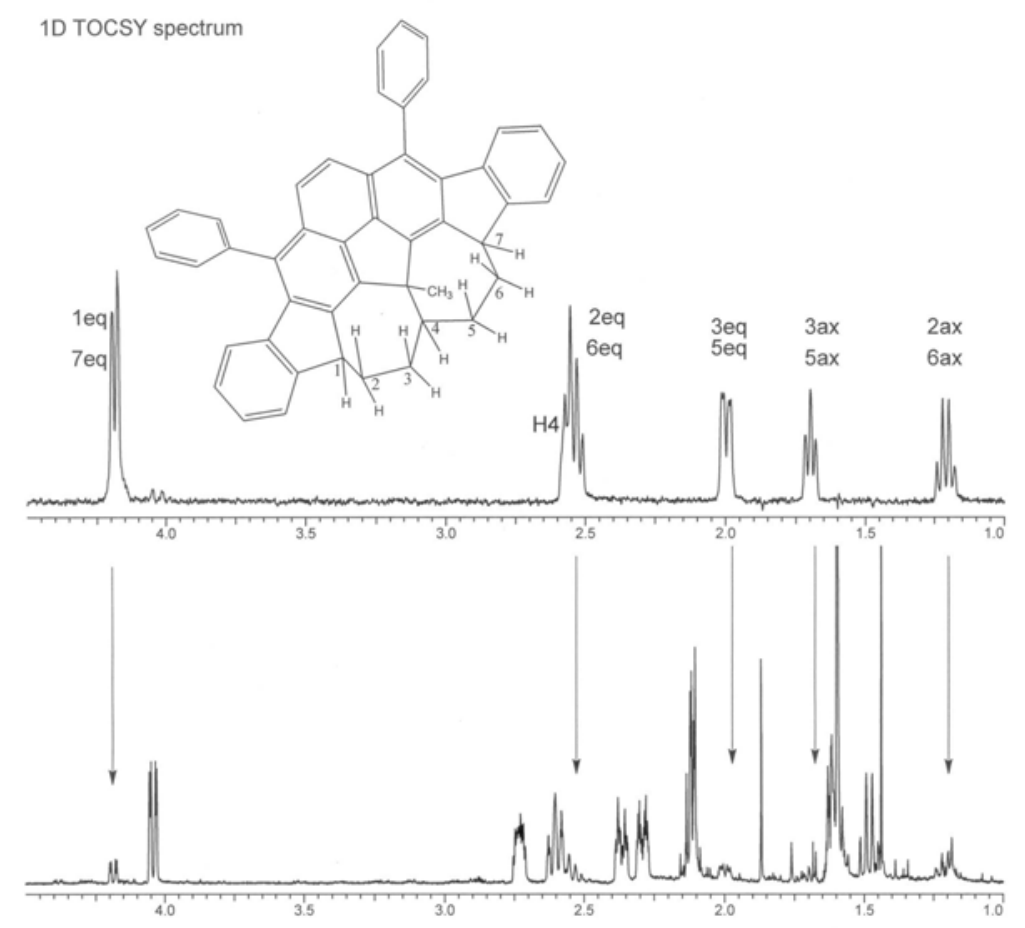

Figure 23. 1D TOCSY spectrum of compound 240. 
The structure of $\mathbf{2 4 7}$ was characterized by using a variety of NMR techniques including two-dimensional NOESY, gHSQC, and gHMBC. The stereochemistry was also assigned on the basis of one-dimentional NOSEY experiments (Figure 24).

In the NOESY spectrum of 247 (Figure 24), $\mathrm{CH}_{3}$ protons at $1.68 \mathrm{ppm}$ shows strong nOes to $\mathrm{H}_{3}{ }^{\mathrm{a}}$ proton at $2.81 \mathrm{ppm}, \mathrm{H}_{4}{ }^{\mathrm{a}}$ proton at $2.69 \mathrm{ppm}$, and $\mathrm{H}_{6}$ proton at $4.12 \mathrm{ppm} . \mathrm{H}_{3}{ }^{\mathrm{a}}$ proton at $2.81 \mathrm{ppm}$ shows strong nOes to $\mathrm{CH}_{3}$ protons at $1.68 \mathrm{ppm}, \mathrm{H}_{4}{ }^{\mathrm{a}}$ proton at $2.69 \mathrm{ppm}$, and $\mathrm{H}_{2}{ }^{\mathrm{a}}$ proton at $1.63 \mathrm{ppm} . \mathrm{H}_{6}$ proton at $4.12 \mathrm{ppm}$ shows strong nOes to $\mathrm{CH}_{3}$ protons at 1.68 ppm, $\mathrm{H}_{5}{ }^{a}$ proton at $1.56 \mathrm{ppm}$, and $\mathrm{H}_{8}{ }^{\mathrm{a}}$ proton at $7.50 \mathrm{ppm}$. Therefore, the $\mathrm{CH}_{3}$ group is in the same orientation with $\mathrm{H}_{3}$ proton, and $\mathrm{H}_{6}$ proton.

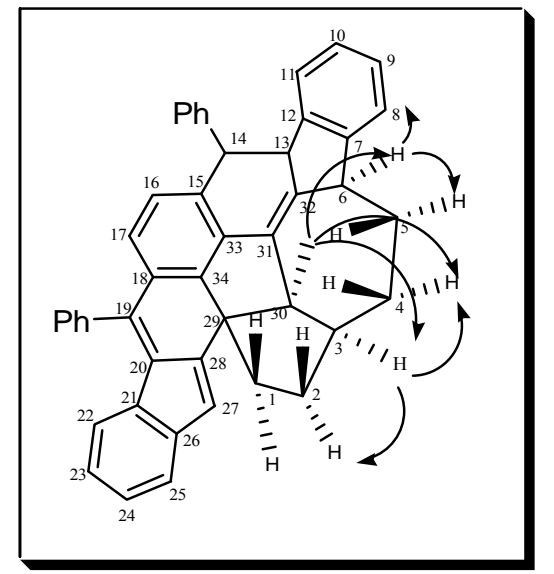

Figure 24. nOe of compound 247.

In the NOESY spectrum of $\mathbf{2 4 0}$ (Figure 24), $\mathrm{H}_{1}$ proton and $\mathrm{H}_{7}$ proton at $4.27 \mathrm{ppm}$ shows strong nOes to $\mathrm{H}_{2}{ }^{a}$ proton and $\mathrm{H}_{6}{ }^{a}$ proton at $1.35 \mathrm{ppm}$, and $\mathrm{CH}_{3}$ protons at $1.96 \mathrm{ppm}$. $\mathrm{CH}_{3}$ protons at $1.68 \mathrm{ppm}$ shows strong nOes to $\mathrm{H}_{1}$ proton and $\mathrm{H}_{7}$ proton at $4.27 \mathrm{ppm}$, and $\mathrm{H}_{2}{ }^{\mathrm{a}}$ proton and $\mathrm{H}_{6}{ }^{a}$ proton at $1.35 \mathrm{ppm}$. In addition, $\mathrm{H}_{2}{ }^{\beta}$ proton and $\mathrm{H}_{6}{ }^{\beta}$ proton at $2.61 \mathrm{ppm}$ show strong nOes only to $\mathrm{H}_{2}{ }^{a}$ proton and $\mathrm{H}_{6}{ }^{a}$ proton at $1.35 \mathrm{ppm}$. Therefore, the $\mathrm{CH}_{3}$ group is in the same orientation with $\mathrm{H}_{1}$ proton, $\mathrm{H}_{7}$ proton and $\mathrm{H}_{4}$ proton. 


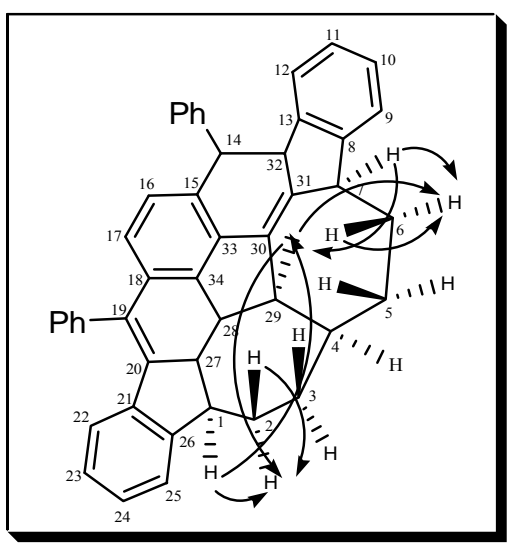

Figure 25. nOe of compound 240.

\subsection{Attempted synthesis of fused polycyclic aromatic hydrocarbons via intramolecular Barbier reaction}

The use of samarium(II) iodide for reductive coupling to promote intramolecular Barbier-type reaction between alkyl halides and carbonyl groups to form fused PAHs was also explored. ${ }^{107}$ We have investigated $\mathrm{SmI}_{2}$-mediated intramolecular Barbier reaction with dibromide 252 (Scheme 72). Propargylic diol 235 was converted to the corresponding diketone 250 using the cascade reaction sequence with air oxidation in the presence of sodium hydroxide. Demethylation of the methoxy groups in $\mathbf{2 5 0}$ with boron tribromide to give $\mathbf{2 5 1}$ followed by bromination with carbon tetrabromide and triphenylphosphine furnished dibromide $\mathbf{2 5 2}$ from $\mathbf{2 5 0}$ in only $23 \%$ overall yield.

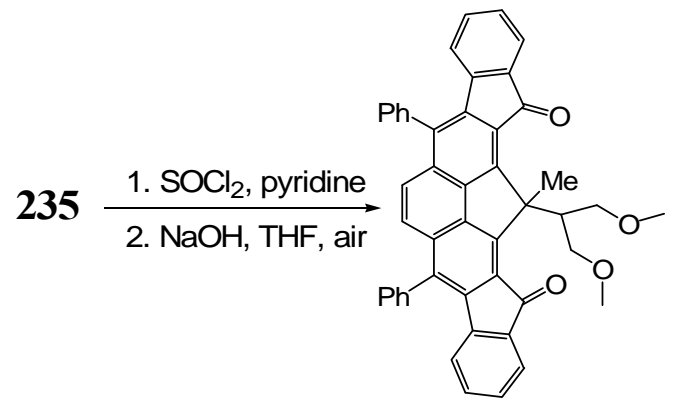

250: $42 \%$
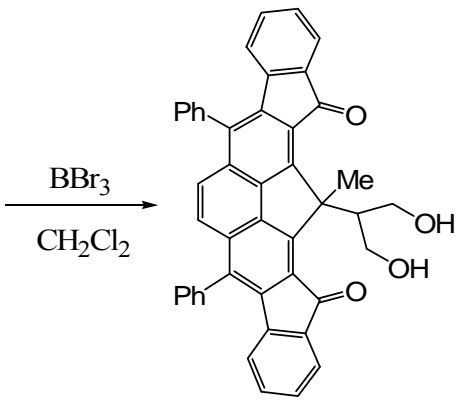

251

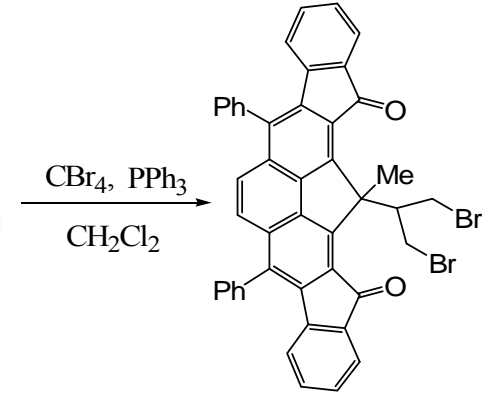

252: $23 \%$

Scheme 72. Synthesis of diketone 252 containing alkyl dibromide. 
Diketone 254 having a longer alkyl chain on each of the alkyl chain connecting to the iodo substituent was likewise synthesized as outlined in scheme 73. Propargylic diol 246 was converted to the corresponding diketone $\mathbf{2 5 3}$, and then treatment with trimethylsilyl iodide produced 254 .

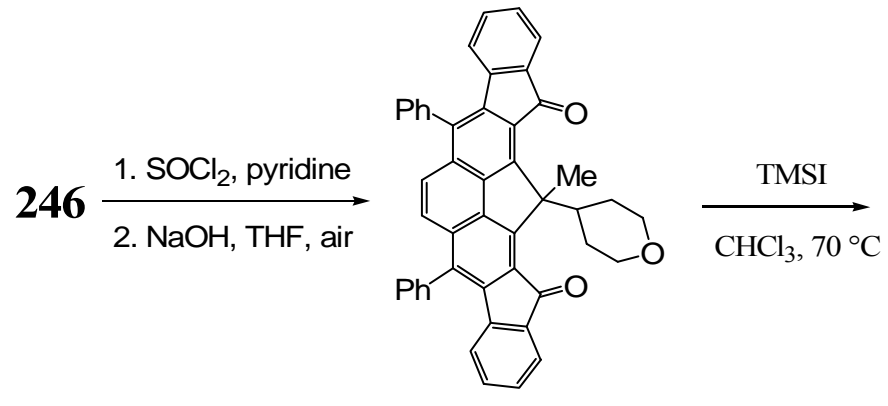

253: $49 \%$

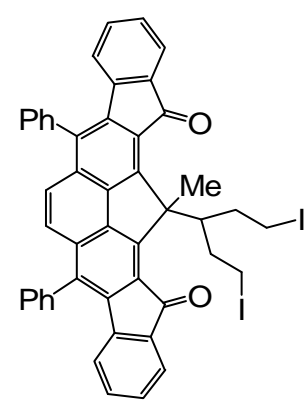

254: $68 \%$

Scheme 73. Synthesis of diketone containing alkyl iodide.

However, attempts for intramolecular condensation using Samarium-Barbier reaction were unsuccessful. The ${ }^{1} \mathrm{H}$ NMR spectrum of the crude reaction mixture showed broad peaks in the aromatic region.

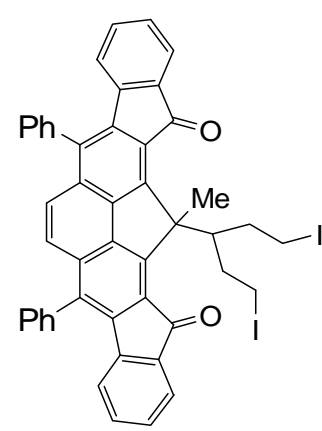

254

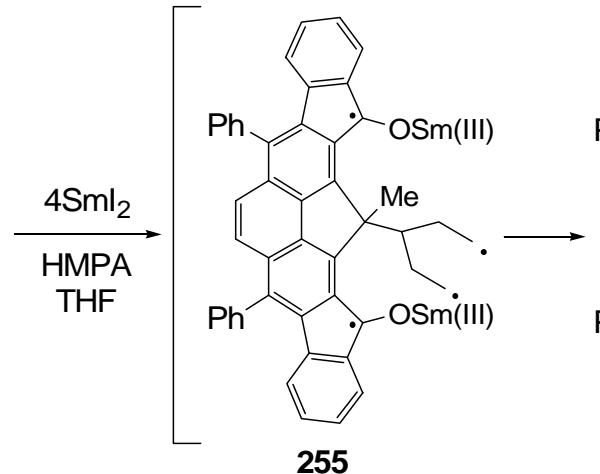

255

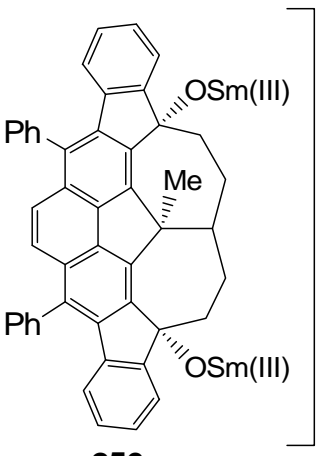

256

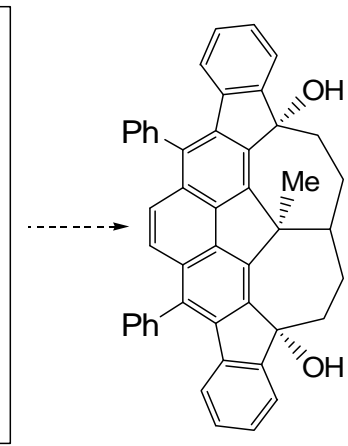

257

Scheme 74. The preparation of all fused rings via Samarium-Barbier reaction.

\subsection{Attempted synthesis of pentaindenocorannulene 203}

Another diketone $\mathbf{2 6 2}$ was also synthesized by the same synthetic sequence. The 
retrosynthetic sequence for pentaindenocorannulene $\mathbf{2 0 3}$ is outlined in Scheme 75 . It was presumed that tetraketone 264 could undergo intramolecular ring closure via McMurry coupling reactions between the keto groups. The structure of 263 has a bowl shape and bears a corannulene unit. Subsequent intramolecular arylation reactions could furnish pentaindenocorannulene 203.

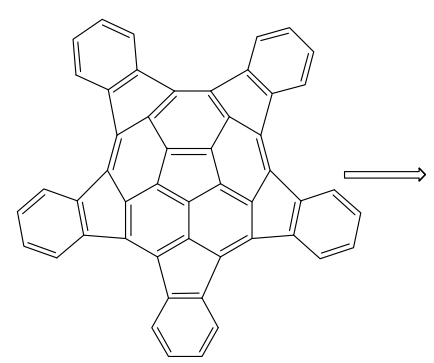

203

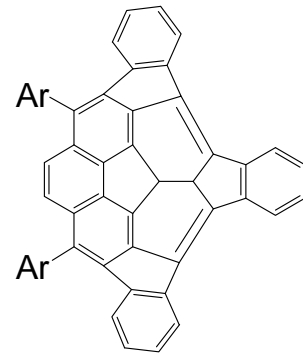

263

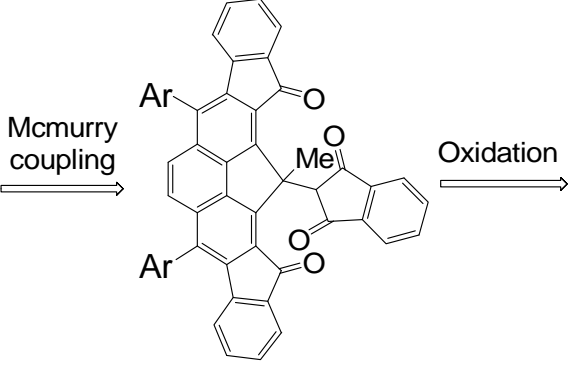

264

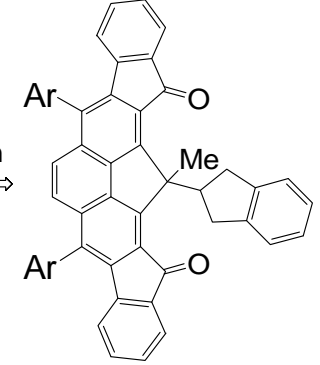

262

$\mathrm{Ar}=$ ortho-boromophenyl

Scheme 75. Retrosynthetic analysis for the preparation of PAH 203 containing a corannulene unit.

The synthetic sequence outlined in Scheme 65 was adopted for the preparation of $\mathbf{2 6 2}$. From the methylated diketone 260, the propargylic diol 261 was then converted to 262 by the cascade cyclization sequence followed by air oxidation in the presence of sodium hydroxide.

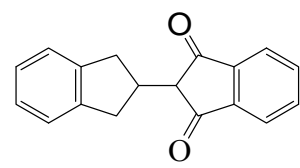

259: $80 \%$

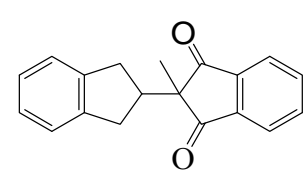

260: $79 \%$

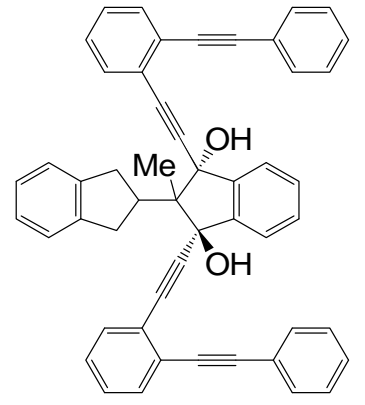

261: $82 \%$

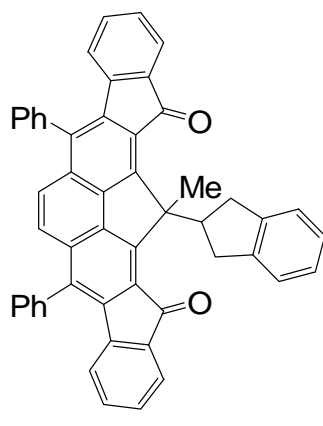

262: $28 \%$

Scheme 76. Synthesis of diketone 262. 
The oxidation of diketone $\mathbf{2 6 2}$ outlined in Scheme 77 was carried out via light-induced radical bromination of the benzyl positions with $N$-bromosuccinimide or bromine. After radical bromination, NMR spectrum showed many uidentified peaks in the aromatic region. All attempts to furnish dibromide 265 were unsuccessful.

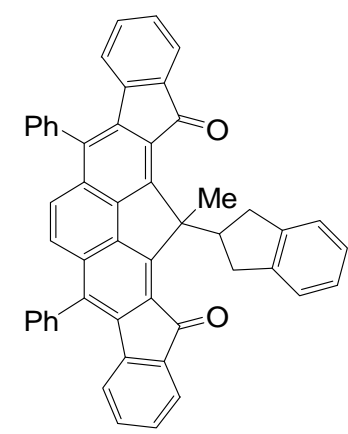

262

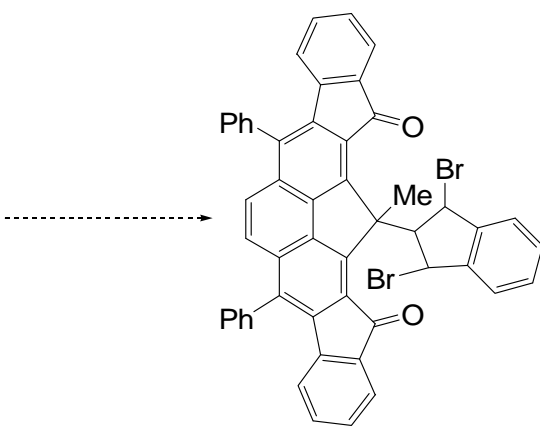

265

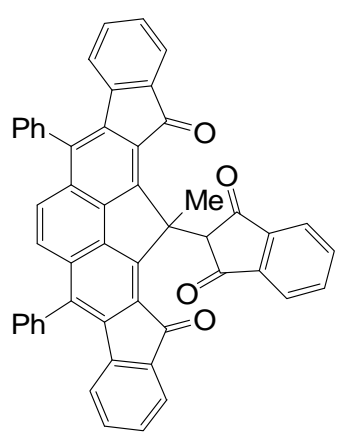

264

Scheme 77. Attempted radical bromination of 262.

\section{Conclusion}

Polycyclic aromatic hydrocarbon 240, bearing a ten fused ring system and $\mathbf{2 4 7}$ were successfully synthesized from a diindeno-fused $4 H$-cyclopenta[def]phenanthrene precursor. Direct tandem Knoevenagel/hydrogenation reaction sequence also furnished valuable diketones as potential precursors of a variety of PAHs. It is also worth noting that the cascade cyclization sequence via an enyne-allene intermediate is an efficient pathway for the construction of a variety of diverse carbon backbones as potential precursors of bowl-shaped PAHs. 


\section{Part V}

\section{Experimental Section}

All reactions were conducted in oven-dried $\left(120^{\circ} \mathrm{C}\right)$ glassware under a nitrogen or an argon atmosphere. Diethyl ether $\left(\mathrm{Et}_{2} \mathrm{O}\right)$ and tetrahydrofuran (THF) were distilled from benzophenone ketyl prior to use. Methylene chloride, benzene, toluene, and $p$-xylene were also distilled over calcium hydride $\left(\mathrm{CaH}_{2}\right)$ prior to use. Silica gel for flash column chromatography was purchased from chemical suppliers. Melting points were uncorrected. ${ }^{1} \mathrm{H}$ $(270 \mathrm{MHz})$ and ${ }^{13} \mathrm{C}(67.9 \mathrm{MHz}) \mathrm{NMR}$ spectra were recorded in $\mathrm{CDCl}_{3}$ using $\mathrm{CHCl}_{3}\left({ }^{1} \mathrm{H} \delta 7.26\right)$ and $\mathrm{CDCl}_{3}\left({ }^{13} \mathrm{C} \delta 77.0\right)$ as internal standards unless otherwise indicated for those recorded on a 600-MHz NMR spectrometer (Varian VXR-600). IR spectra were taken on Perkin-Elmer LX10-8704 Spectrum One FT-IR spectrometer. Mass spectra and high resolution mass spectra were obtained on Hewlett Packard 5970B GC/MSD instrument at $70 \mathrm{eV}$, VG 7070 by DEI, VG-ZAB by FAB and DE-STR by MALDI.

$n$-Butyllithium $(2.5 \mathrm{M})$ in hexanes, $t$-butyllithium $(1.7 \mathrm{M})$ in pentane, lithium diisopropylamide (LDA, 2.0 M) in THF/n-heptane/ethylbenzene, $\mathrm{CuBr} \cdot \mathrm{SMe}_{2}$, triethylsilane, trifluoroacetic acid, potassium tert-butoxide $(1.0 \mathrm{M})$ in 2-methyl-2-propanol, potassium tert-butoxide, 2-methyl-2-propanol, triethylamine, phenylacetylene, (trimethylsilyl)acetylene, $\operatorname{Pd}\left(\mathrm{PPh}_{3}\right)_{2} \mathrm{Cl}_{2}$, copper(I) iodide, 2,2-dimethylpropiophenone (122), triphenylphosphine, $\mathrm{Pd}\left(\mathrm{PPh}_{3}\right)_{2} \mathrm{Br}_{2}, 1,8$-diazabicyclo[5.4.0] undec-7-ene (DBU), boron tribromide (1.0 M solution in 
dichloromethane), methanol, ethanol, (1S)-(+)-10-camphorsulfonyl chloride, 1-ethynyl-3-methoxybenze-ne, 1-ethynyl-2-methoxybenzene, 1-ethynyl-2-iodobenzene, 4-ethynylanisole, 4-ethynylaniline, hexamethyl phosphoramide, samarium(II) iodide, thionyl chloride, pyridine, tetrahydro-4H-pyran-4-one, 1,3-indanedione, L-proline, iodotrimethyl silane, methyl iodide, tri-n-butyltin hydride were purchased from chemical suppliers and were used as received.

(2,6-Dibromophenyl)ethyne (134) ${ }^{81}\left[(2\right.$-iodophenyl)ethynyl $]$ trimethylsilane (135) ${ }^{82}$ 2,2-dimethyl-1-indanone (144b), ${ }^{51 \mathrm{~g}}$ and Hantzsch ester ${ }^{105 a}$ were prepared as reported previously.

[[2-[(2,6-Dibromophenyl)ethynyl]phenyl]ethynyl]trimethylsilane (136). To a flask containing $0.17 \mathrm{~g}$ of dichlorobis(triphenylphosphine)palladium $(0.24 \mathrm{mmol})$ and $0.030 \mathrm{~g}$ of $\mathrm{CuI}(0.16 \mathrm{mmol})$ were added via cannula a solution of $1.42 \mathrm{~g}$ of $\mathbf{1 3 5}(4.74 \mathrm{mmol})$ in $20 \mathrm{~mL}$ of triethylamine followed by a solution of $1.23 \mathrm{~g}$ of $\mathbf{1 3 4}(4.74 \mathrm{mmol})$ in $20 \mathrm{~mL}$ of triethylamine. The resulting mixture was stirred vigorously for $12 \mathrm{~h}$. The mixture was then filtered to remove solid particles, and the filtrate was concentrated. The residue was purified by flash column chromatography (silica gel/hexanes) to give $1.72 \mathrm{~g}$ of $\mathbf{1 3 6}(3.98 \mathrm{mmol}, 84 \%)$ as a yellow liquid: $R_{f}=0.67$ (hexanes:diethyl ether $\left.=9: 1\right) ;$ IR $2158,1421 \mathrm{~cm}^{-1} ;{ }^{1} \mathrm{H} \delta 7.65-7.62(1 \mathrm{H}, \mathrm{m}), 7.57(2 \mathrm{H}$, $\mathrm{d}, J=8.2 \mathrm{~Hz}), 7.55-7.51(1 \mathrm{H}, \mathrm{m}), 7.35-7.27(2 \mathrm{H}, \mathrm{m}), 7.02(1 \mathrm{H}, \mathrm{t}, J=8.2 \mathrm{~Hz}), 0.26(9 \mathrm{H}, \mathrm{s})$;

${ }^{13} \mathrm{C} \delta 132.9,132.7,131.2,129.7,128.5,128.1,127.2,126.4,125.3,125.1,103.2,99.0,97.0$, 90.9, 0.1; MS m/z 434/432/430 (M+), 419/417/415. 
Benzannulated Enediyne 137. To $1.72 \mathrm{~g}$ of $136(3.98 \mathrm{mmol})$ in $50 \mathrm{~mL}$ of diethyl ether were added $50 \mathrm{~mL}$ of a $10 \% \mathrm{NaOH}$ solution and $50 \mathrm{~mL}$ of methanol. After $10 \mathrm{~h}$ at room temperature, $35 \mathrm{~mL}$ of $6 \mathrm{M} \mathrm{HCl}$ solution was added slowly. The organic layer was separated, dried over $\mathrm{MgSO}_{4}$, and concentrated. The residue was purified by flash column chromatography (silica gel/hexanes) to afford $1.29 \mathrm{~g}$ of $137(3.58 \mathrm{mmol}, 90 \%)$ as a yellow solid: $R_{f}=0.52$ (hexanes:diethyl ether $=9: 1)$; IR 3293, $1423 \mathrm{~cm}^{-1} ;{ }^{1} \mathrm{H} \delta 7.67-7.62(1 \mathrm{H}, \mathrm{m}), 7.57(2 \mathrm{H}, \mathrm{d}, J=$ $8.2 \mathrm{~Hz}), 7.55-7.52(1 \mathrm{H}, \mathrm{m}), 7.38-7.28(2 \mathrm{H}, \mathrm{m}), 7.02(1 \mathrm{H}, \mathrm{t}, J=8.2 \mathrm{~Hz}), 3.37(1 \mathrm{H}, \mathrm{s}) ;{ }^{13} \mathrm{C} \delta$ $132.7,132.6,131.3,129.8,128.7,128.5,127.1,126.5,125.8,124.4,96.6,90.9,82.0,81.8 ; \mathrm{MS}$ $m / z 362 / 360 / 358(\mathrm{M}+), 281 / 279,200$.

\section{$\alpha-[[2-[(2,6-D i b r o m o p h e n y l) e t h y n y l] p h e n y l]$ ethynyl]-a-(1,1- dimethylethyl)benzene}

methanol (138). To $0.567 \mathrm{~g}(1.57 \mathrm{mmol})$ of $137 \mathrm{in} 40 \mathrm{~mL}$ of THF under a nitrogen atmosphere at $0{ }^{\circ} \mathrm{C}$ was added $0.887 \mathrm{~mL}$ of a $2.0 \mathrm{M}$ solution of LDA $(1.7 \mathrm{mmol})$ in THF $/ n$-heptane. After $30 \mathrm{~min}$ of stirring, a solution of $0.255 \mathrm{~g}$ of pivalophenone $(\mathbf{1 2 2}, 1.57 \mathrm{mmol})$ in $20 \mathrm{~mL}$ of THF was introduced via cannula, and the reaction mixture was allowed to warm to room temperature. After an additional $2 \mathrm{~h}, 50 \mathrm{~mL}$ of water was introduced, and the reaction mixture was extracted with diethyl ether. The combined organic extracts were washed with brine and water, dried over sodium sulfate, and concentrated. The residue was purified by flash column chromatography (silica gel $/ 40 \%$ diethyl ether in hexanes, $\left.R_{f}=0.64\right)$ to provide $0.607 \mathrm{~g}(1.16$ mmol, 74\%) of 138 as a viscous yellow liquid: IR 3563, $1483 \mathrm{~cm}^{-1} ;{ }^{1} \mathrm{H} \delta 7.70-7.62(3 \mathrm{H}, \mathrm{m})$, 7.58-7.54 (1 H, m), $7.53(2 \mathrm{H}, \mathrm{d}, J=8.2 \mathrm{~Hz}), 7.38-7.31(2 \mathrm{H}, \mathrm{m}), 7.24-7.19(3 \mathrm{H}, \mathrm{m}), 7.00$ (1 
$\mathrm{H}, \mathrm{t}, J=7.9 \mathrm{~Hz}), 2.5(1 \mathrm{H}, \mathrm{br} \mathrm{s}), 1.05(9 \mathrm{H}, \mathrm{s}) ;{ }^{13} \mathrm{C} \delta 141.9,132.5,132.3,131.2,129.8,128.6$, $128.0,127.8,127.2,127.1,126.9,126.5,125.3,124.9,97.0,96.6,90.7,84.3,79.4,39.7,25.5$.

Benzannulated Enediyne 139. To a mixture of $138(0.607 \mathrm{~g}, 1.16 \mathrm{mmol})$ and triethylsilane $(0.405 \mathrm{~g}, 3.48 \mathrm{mmol})$ in $30 \mathrm{~mL}$ of methylene chloride was added $0.71 \mathrm{~mL}$ of trifluoroacetic acid (1.06 g, $9.28 \mathrm{mmol})$. After five min of stirring at room temperature, $0.99 \mathrm{~g}$ of sodium carbonate $(9.3 \mathrm{mmol})$ was added followed by $20 \mathrm{~mL}$ of water and $50 \mathrm{~mL}$ of diethyl ether. The organic layer was separated, dried over sodium sulfate, and concentrated. Purification of the residue by flash column chromatography ( silica gel $/ 20 \%$ diethyl ether in hexanes, $R_{f}=0.46$ ) provided $0.546 \mathrm{~g}(1.08 \mathrm{mmol}, 93 \%)$ of 139 as a yellow liquid: IR $2219,1421 \mathrm{~cm}^{-1} ;{ }^{1} \mathrm{H} \delta$ 7.69-7.65 (1 H, m), 7.60-7.55 (1 H, m), $7.55(2 \mathrm{H}, \mathrm{d}, J=7.9 \mathrm{~Hz}), 7.47-7.18(7 \mathrm{H}, \mathrm{m}), 6.99$ (1 $\mathrm{H}, \mathrm{t}, J=8.2 \mathrm{~Hz}), 3.75(1 \mathrm{H}, \mathrm{s}), 1.09(9 \mathrm{H}, \mathrm{s}) ;{ }^{13} \mathrm{C} \delta 138.9, .132 .4,132.3,131.1,129.8,129.6$, $128.5,127.5,127.3,126.6,126.5,126.4,124.7,97.3,96.1,90.3,82.2,50.6,35.4,27.7$.

5-(2,6-Dibromophenyl)-10-(1,1-dimethylethyl)-11H-benzo[b]fluorene (132). To $0.546 \mathrm{~g}$ of $139(1.08 \mathrm{mmol})$ in $30 \mathrm{~mL}$ of anhydrous toluene under a nitrogen atmosphere was added 1.08 $\mathrm{mL}$ of a $1.0 \mathrm{M}$ solution of potassium tert-butoxide $(1.08 \mathrm{mmol})$ in 2-methyl-2-propanol. The reaction mixture was then heated under reflux for $12 \mathrm{~h}$. After the reaction mixture was allowed to cool to room temperature, $20 \mathrm{~mL}$ of water and $40 \mathrm{~mL}$ of diethyl ether were introduced, and the organic layer was separated, dried over sodium sulfate, and concentrated. The residue was purified by flash column chromatography ( provide $0.382 \mathrm{~g}$ of $132(0.755 \mathrm{mmol}, 70 \%)$ as a yellow solid: IR $1546,1423 \mathrm{~cm}^{-1} ;{ }^{1} \mathrm{H} \delta 8.69(1$ $\mathrm{H}, \mathrm{d}, J=8.9 \mathrm{~Hz}), 7.83(2 \mathrm{H}, \mathrm{d}, J=8.2 \mathrm{~Hz}), 7.65-7.17(6 \mathrm{H}, \mathrm{m}), 7.08(1 \mathrm{H}, \mathrm{t}, J=7.7 \mathrm{~Hz}), 6.36$ 
$(1 \mathrm{H}, \mathrm{d}, J=7.9 \mathrm{~Hz}), 4.56(2 \mathrm{H}, \mathrm{s}), 1.95(9 \mathrm{H}, \mathrm{s}) ;{ }^{13} \mathrm{C} \delta 144.3,142.1,140.7,139.5,137.9,137.6$, $132.4,131.6,131.3,130.5,128.3,127.3,126.8,126.0,125.5,124.7,124.1,123.6,122.0,40.3$, 38.9, 34.5 ; MS m/z 508/506/504 (M+), 493/491/489, 451/449/447.

Buckybowl 133 and Hydrocarbon 143. To a flask containing $0.139 \mathrm{~g}$ of $132(0.274 \mathrm{mmol})$ and $0.022 \mathrm{~g}$ of dibromobis(triphenylphosphine)palladium $(0.0274 \mathrm{mmol})$ under a nitrogen atmosphere were added via cannula $0.409 \mathrm{~mL}$ of DBU $(2.74 \mathrm{mmol})$ in $10 \mathrm{~mL}$ of DMF. The resulting mixture was stirred vigorously at $150{ }^{\circ} \mathrm{C}$ for $72 \mathrm{~h}$. The reaction mixture was then allowed to cool to room temperature before $20 \mathrm{~mL}$ of water, $10 \mathrm{~mL}$ of a $2 \mathrm{M} \mathrm{HCl}$ solution, and $40 \mathrm{~mL}$ of diethyl ether were introduced. The organic layer was separated, dried over sodium sulfate, and concentrated. The residue was purified by flash column chromatography (silica gel/hexanes) to provide $0.035 \mathrm{~g}$ of $133(0.102 \mathrm{mmol}, 37 \%)$ and $0.015 \mathrm{~g}$ of $143(0.044 \mathrm{mmol}$, $16 \%)$ as yellow solids.

133: IR 1364, $1218 \mathrm{~cm}^{-1} ;{ }^{1} \mathrm{H} \delta 8.42(1 \mathrm{H}, \mathrm{d}, J=8.4 \mathrm{~Hz}), 8.30(1 \mathrm{H}, \mathrm{t}, J=3.6 \mathrm{~Hz}), 8.24(1 \mathrm{H}, \mathrm{d}$, $J=7.8 \mathrm{~Hz}), 8.01(1 \mathrm{H}, \mathrm{d}, J=7.2 \mathrm{~Hz}), 7.96(1 \mathrm{H}, \mathrm{d}, J=7.2 \mathrm{~Hz}), 7.65-7.58(3 \mathrm{H}, \mathrm{m}), 7.55(1 \mathrm{H}$, $\mathrm{dd}, J=8.4,7.2 \mathrm{~Hz}), 4.75(2 \mathrm{H}, \mathrm{s}), 1.87(9 \mathrm{H}, \mathrm{s}) ;{ }^{13} \mathrm{C} \delta 147.3,145.1,140.0,139.2,138.4,137.4$, $136.7,135.0,131.9,130.6,129.3,129.1,128.8,128.1,127.6,126.5,123.9,123.1,122.4,122.0$, 45.0, 38.5, 33.6; MS m/z $344(\mathrm{M}+), 329,313,300$; HRMS calcd for $\mathrm{C}_{27} \mathrm{H}_{20}$ 344.1565, found 344.1552. Recrystallization from a mixture of methylene chloride and ethanol produced a single crystal suitable for X-ray structure analysis. 143: IR 1443, $1365 \mathrm{~cm}^{-1} ;{ }^{1} \mathrm{H} \delta 8.67(1 \mathrm{H}, \mathrm{d}$, $J=7.8 \mathrm{~Hz}), 8.55(1 \mathrm{H}, \mathrm{d}, J=7.2 \mathrm{~Hz}), 8.47(1 \mathrm{H}, \mathrm{d}, J=8.4 \mathrm{~Hz}), 7.96(1 \mathrm{H}, \mathrm{d}, J=7.2 \mathrm{~Hz}), 7.90$ $(1 \mathrm{H}, \mathrm{d}, J=7.2 \mathrm{~Hz}), 7.62(1 \mathrm{H}, \mathrm{d}, J=7.8 \mathrm{~Hz}), 7.56(1 \mathrm{H}, \mathrm{dd}, J=8.7,6.9 \mathrm{~Hz}), 7.51-7.37(4 \mathrm{H}$, 
m), $4.54(2 \mathrm{H}, \mathrm{s}), 1.90(9 \mathrm{H}, \mathrm{s}) ;{ }^{13} \mathrm{C} \delta 145.2,142.7,140.3,140.2,139.9,139.7,138.6,137.3$, $134.8,128.0,127.8,127.3,126.9,126.6,125.3,124.5,124.4,124.2,121.0,118.1,40.3,39.0$, 35.0; MS m/z $346(\mathrm{M}+), 331,313,289$; HRMS calcd for $\mathrm{C}_{27} \mathrm{H}_{22} 346.1721$, found 346.1720. The structure of $\mathbf{1 4 3}$ was tentative assigned based on the assumption that the first cyclopalladation reaction of 143 occurred preferentially with the naphthyl moiety of 143 producing a five-membered ring as reported previously. ${ }^{110}$ The resulting brominated fluoranthene intermediate could undergo either a second cyclopalladation reaction to produce 133 or a reductive debromination reaction to give 143. Analysis of the crude reaction mixture by GC/MS before purification by silica gel chromatography also suggests the presence of small amount of $\mathbf{1 3 1}$

\section{1-[[2-[(2,6-Dibromophenyl)ethynyl]phenyl]ethynyl]-1,2,3,4-tetrahydro-2,2-dimethyl-1-n}

aphthalenol (145a). The same procedure was repeated as described for 138 except that 0.557 $\mathrm{g}(1.55 \mathrm{mmol})$ of $\mathbf{1 3 7}$ and $0.270 \mathrm{~g}(1.55 \mathrm{mmol})$ of $\mathbf{1 4 4 a}$ were used to afford $\mathbf{1 4 5 a}(0.572 \mathrm{~g}, 1.07$ mmol, 69\%) as a viscous yellow liquid: IR 3569, $1422 \mathrm{~cm}^{-1} ;{ }^{1} \mathrm{H} \delta 8.01(1 \mathrm{H}, \mathrm{d}, J=7.7 \mathrm{~Hz})$, 7.67-7.62 (1 H, m), $7.56(2 \mathrm{H}, \mathrm{d}, J=8.2 \mathrm{~Hz}) 7.54-7.50(1 \mathrm{H}, \mathrm{m}), 7.36-7.32(2 \mathrm{H}, \mathrm{m})$, 7.18-6.99 (4 H, m), 2.90-2.75 (2 H, m), 2.45 (1 H, s), 2.11-1.95 (1 H, m), 1.78-1.65 (1 H, m), $1.24(3 \mathrm{H}, \mathrm{s}), 1.17(3 \mathrm{H}, \mathrm{s}) ;{ }^{13} \mathrm{C} \delta 138.5,134.9,132.5,132.4,131.2,129.8,128.9,128.8,128.6$, $128.0,127.8,127.1,126.6,126.2,125.3,124.9,97.0,95.6,90.6,84.9,75.2,37.7,31.1,25.8$, 23.8.

Benzannulated Enediyne 146a. The same procedure was repeated as described for 139 except that $0.572 \mathrm{~g}(1.07 \mathrm{mmol})$ of $145 \mathrm{a}$ was used to afford $\mathbf{1 4 6 a}(0.493 \mathrm{~g}, 0.952 \mathrm{mmol}, 89 \%)$ 
as a viscous yellow liquid: IR 2220, $1422 \mathrm{~cm}^{-1} ;{ }^{1} \mathrm{H} \delta 7.70-7.62(2 \mathrm{H}, \mathrm{m}), 7.56(2 \mathrm{H}, \mathrm{d}, J=8.2$ Hz), 7.53-7.48 (1 H, m), 7.35-7.27 (2 H, m), 7.14-6.99 (4 H, m), 3.80 (1 H, s), 3.02-2.72 (2 H, m), $1.82(1 \mathrm{H}, \mathrm{ddd}, J=13.3,6.2,4.7 \mathrm{~Hz}), 1.60(1 \mathrm{H}, \mathrm{ddd}, J=13.4,8.3,6.4 \mathrm{~Hz}), 1.19(3 \mathrm{H}, \mathrm{s})$, $1.08(3 \mathrm{H}, \mathrm{s}) ;{ }^{13} \mathrm{C} \delta 135.3,134.9,132.5,132.4,131.2,129.7,129.6,128.62,128.56,127.4$, $126.6,126.5,126.3,125.8,124.8,97.5,95.4,90.3,82.7,44.7,35.2,33.3,29.2,26.2,22.6$.

\section{7-(2,6-Dibromophenyl)-1,2,3,12-tetrahydro-1,1-dimethylindeno[2,1-a]phenalene (147a).}

The same procedure was repeated as described for 132 except that $0.493 \mathrm{~g}(0.952 \mathrm{mmol})$ of 146a was used to afford $147 \mathrm{a}(0.326 \mathrm{~g}, 0.629 \mathrm{mmol}, 66 \%)$ as a yellow solid: IR 1365, 1217 $\mathrm{cm}^{-1} ;{ }^{1} \mathrm{H} \delta 7.81(2 \mathrm{H}, \mathrm{d}, J=8.2 \mathrm{~Hz}), 7.56(1 \mathrm{H}, \mathrm{d}, J=7.4 \mathrm{~Hz}), 7.35-7.19(5 \mathrm{H}, \mathrm{m}), 7.08(1 \mathrm{H}, \mathrm{t}$, $J=7.4 \mathrm{~Hz}), 6.38(1 \mathrm{H}, \mathrm{d}, J=7.9 \mathrm{~Hz}), 4.37(2 \mathrm{H}, \mathrm{s}), 3.22(2 \mathrm{H}, \mathrm{t}, J=6.5 \mathrm{~Hz}), 2.07(2 \mathrm{H}, \mathrm{t}, J=6.4$ Hz), $1.65(6 \mathrm{H}, \mathrm{s}) ;{ }^{13} \mathrm{C} \delta 144.2,140.9,140.1,140.0,137.8,136.7,136.0,132.4,131.4,130.7$, $130.4,129.2,127.3,126.9,126.1,125.0,124.5,124.3,122.8,122.1,40.138 .7,36.1,28.9$, 28.1 .

Buckybowl 148a and Hydrocarbon 149a. The same procedure was repeated as described for 133 and 143 except that $0.194 \mathrm{~g}(0.374 \mathrm{mmol})$ of $147 \mathbf{a}$ was used to afford $148 \mathrm{a}(0.056 \mathrm{~g}, 0.157$ mmol, 42\%) and 149a (0.028 g, $0.078 \mathrm{mmol}, 21 \%)$ as yellow solids. 23a: IR 1363, $1217 \mathrm{~cm}^{-1}$; ${ }^{1} \mathrm{H} \delta(600 \mathrm{MHz}) 8.28(1 \mathrm{H}, \mathrm{d}, J=7.8 \mathrm{~Hz}), 8.20(1 \mathrm{H}, \mathrm{d}, J=7.2 \mathrm{~Hz}), 7.96(1 \mathrm{H}, \mathrm{d}, J=7.2 \mathrm{~Hz})$, $7.89(1 \mathrm{H}, \mathrm{d}, J=7.2 \mathrm{~Hz}), 7.61-7.58(3 \mathrm{H}, \mathrm{m}), 7.31(1 \mathrm{H}, \mathrm{d}, J=6.6 \mathrm{~Hz}), 4.60(2 \mathrm{H}, \mathrm{s}), 3.20(2 \mathrm{H}$, $\mathrm{t}, J=6 \mathrm{~Hz}), 2.17(2 \mathrm{H}, \mathrm{t}, J=5.4 \mathrm{~Hz}), 1.53(6 \mathrm{H}, \mathrm{s}) ;{ }^{13} \mathrm{C} \delta(600 \mathrm{MHz}) 145.6,144.6,141.3,140.4$, $140.2,138.7,138.0,137.2,136.1,135.3,131.3,131.0,129.8,129.5,127.9,127.4,125.0,123.3$, 122.7, 122.5, 122.2, 41.8, 40.0, 35.5, 28.3, 25.9; MS m/z $356(\mathrm{M}+), 341,326$; HRMS calcd for 
$\mathrm{C}_{28} \mathrm{H}_{20} 356.1565$, found 356.1562 . Recrystallization from a mixture of methylene chloride and ethanol produced a single crystal suitable for X-ray structure analysis. 149a: IR 1365, 1218 $\mathrm{cm}^{-1} ;{ }^{1} \mathrm{H} \delta 8.70(1 \mathrm{H}, \mathrm{d}, J=7.7 \mathrm{~Hz}), 8.55(1 \mathrm{H}, \mathrm{d}, J=7.2 \mathrm{~Hz}), 7.97(1 \mathrm{H}, \mathrm{d}, J=6.7 \mathrm{~Hz}), 7.87(1$ $\mathrm{H}, \mathrm{d}, J=6.9 \mathrm{~Hz}), 7.67(1 \mathrm{H}, \mathrm{d}, J=7.2), 7.54(1 \mathrm{H}, \mathrm{t}, J=7.2 \mathrm{~Hz}), 7.48-7.34(4 \mathrm{H}, \mathrm{m}), 4.37(2 \mathrm{H}$, $\mathrm{s}), 3.21(2 \mathrm{H}, \mathrm{t}, J=6.2 \mathrm{~Hz}), 2.10(2 \mathrm{H}, \mathrm{t}, J=6.4 \mathrm{~Hz}), 1.62(6 \mathrm{H}, \mathrm{s}) ;{ }^{13} \mathrm{C} \delta 145.1,140.6,140.29$, $140.25,139.9,139.2,138.8,136.7,134.4,133.1,129.0,127.9,126.8,126.6,125.9,124.9$, 124.6, 124.5, 120.8, 118.9, 41.7, 38.5, 35.6, 28.2, 26.7; MS m/z $358(\mathrm{M}+), 343$.

\section{1-[[2-[(2,6-Dibromophenyl)ethynyl]phenyl]ethynyl]-2,3-dihydro-2,2-dimethyl-1H-inden}

-1-ol (145b). The same procedure was repeated as described for $\mathbf{1 3 8}$ except that $0.706 \mathrm{~g}$ (1.96 $\mathrm{mmol})$ of 137 and $0.314 \mathrm{~g}(1.96 \mathrm{mmol})$ of $144 \mathrm{~b}$ were used to afford $145 \mathrm{~b}(0.661 \mathrm{~g}, 1.27 \mathrm{mmol}$, $65 \%$ ) as a viscous yellow liquid: IR 3561, $1422 \mathrm{~cm}^{-1} ;{ }^{1} \mathrm{H} \delta 7.68-7.58(2 \mathrm{H}, \mathrm{m}), 7.55(2 \mathrm{H}, \mathrm{d}, J$ $=8.2 \mathrm{~Hz}), 7.53-7.50(1 \mathrm{H}, \mathrm{m}), 7.35-7.30(2 \mathrm{H}, \mathrm{m}), 7.23-7.20(2 \mathrm{H}, \mathrm{m}), 7.09(1 \mathrm{H}, \mathrm{t}, J=7.2$ $\mathrm{Hz}), 7.01(1 \mathrm{H}, \mathrm{t}, J=7.9 \mathrm{~Hz}), 3.00(1 \mathrm{H}, \mathrm{d}, J=15.2 \mathrm{~Hz}), 2.65(1 \mathrm{H}, \mathrm{d}, J=15.1 \mathrm{~Hz}), 2.32(1 \mathrm{H}$, s), $1.28(3 \mathrm{H}, \mathrm{s}), 1.17(3 \mathrm{H}, \mathrm{s}) ;{ }^{13} \mathrm{C} \delta 145.3,142.5,132.6,132.5,131.2,129.8,128.7,128.6$, $128.1,127.1,126.6,126.5,125.2,125.1,124.9,124.2,97.0,93.0,90.8,85.4,81.7,49.0,44.4$, 26.3, 21.4 .

Benzannulated Enediyne 146b. The same procedure was repeated as described for 139 except that $0.661 \mathrm{~g}(1.27 \mathrm{mmol})$ of $\mathbf{1 4 5 b}$ was used to afford $\mathbf{1 4 6 b}(0.570 \mathrm{~g}, 1.13 \mathrm{mmol}, 89 \%)$ as a viscous yellow liquid: IR 1423, $1217 \mathrm{~cm}^{-1} ;{ }^{1} \mathrm{H} \delta 7.67-7.63(1 \mathrm{H}, \mathrm{m}), 7.55(2 \mathrm{H}, \mathrm{d}, J=8.2 \mathrm{~Hz})$, 7.54-7.49 (1 H, m), 7.44 (1 H, d, $J=7.2 \mathrm{~Hz}), 7.35-7.27$ (2 H, m), 7.18-7.06 (3 H, m), 7.01 (1 $\mathrm{H}, \mathrm{t}, J=8.2 \mathrm{~Hz}), 4.03(1 \mathrm{H}, \mathrm{s}), 2.81(1 \mathrm{H}, \mathrm{d}, J=15.3 \mathrm{~Hz}), 2.71(1 \mathrm{H}, \mathrm{d}, J=15.3 \mathrm{~Hz}), 1.33(3 \mathrm{H}$, 
s), $1.11(3 \mathrm{H}, \mathrm{s}) ;{ }^{13} \mathrm{C} \delta 142.9,142.1,132.6,132.5,131.2,129.6,128.6,127.5,127.4,126.9$, $126.6,126.5,126.4,125.0,124.8,124.6,97.5,93.2,90.5,83.0,49.2,46.6,45.7,27.4,24.3$.

6-(2,6-Dibromophenyl)-2,11-dihydro-1,1-dimethyl-1H-indeno[1,7-ab]fluorine (147b).

The same procedure was repeated as described for 132 except that $0.570 \mathrm{~g}(1.13 \mathrm{mmol})$ of 146b was used to afford $\mathbf{1 4 7 b}(0.353 \mathrm{~g}, 0.70 \mathrm{mmol}, 62 \%)$ as a yellow solid: IR 1423,1217 $\mathrm{cm}^{-1} ;{ }^{1} \mathrm{H} \delta 7.82(2 \mathrm{H}, \mathrm{d}, J=7.9 \mathrm{~Hz}), 7.57(1 \mathrm{H}, \mathrm{d}, J=7.3 \mathrm{~Hz}), 7.41(1 \mathrm{H}, \mathrm{t}, J=7.2 \mathrm{~Hz})$, 7.32-7.24 (3 H, m), 7.14-7.08 (2 H, m), $6.56(1 \mathrm{H}, \mathrm{d}, J=7.9 \mathrm{~Hz}), 4.20(2 \mathrm{H}, \mathrm{s}), 3.38(2 \mathrm{H}, \mathrm{s})$, $1.67(6 \mathrm{H}, \mathrm{s}) ;{ }^{13} \mathrm{C} \delta 148.3,144.3,143.3,141.0,140.0,136.8,133.0,132.3,130.4,129.0,128.2$, $127.7,127.2,127.0,126.0,125.3,125.1,122.2,120.0,119.4,48.5,44.5,33.9,28.1$.

Buckybowl 148b and Hydrocarbon 149b. The same procedure was repeated as described for 133 and 143 except that $0.205 \mathrm{~g}(0.407 \mathrm{mmol})$ of $147 \mathrm{~b}$ was used to afford $148 \mathrm{~b}(0.015 \mathrm{~g}, 0.045$ mmol, 11\%) and 149b (0.032 g, $0.094 \mathrm{mmol}, 23 \%)$ as yellow solids. 148b: IR 1365, 1217 $\mathrm{cm}^{-1} ;{ }^{1} \mathrm{H} \delta 8.24(1 \mathrm{H}, \mathrm{dd}, J=6.6,2.5 \mathrm{~Hz}), 8.15(1 \mathrm{H}, \mathrm{d}, J=7.8 \mathrm{~Hz}), 7.90(1 \mathrm{H}, \mathrm{d}, J=7.2 \mathrm{~Hz})$, $7.79(1 \mathrm{H}, \mathrm{d}, J=7.8 \mathrm{~Hz}), 7.59-7.50(3 \mathrm{H}, \mathrm{m}), 7.20(1 \mathrm{H}, \mathrm{d}, J=7.2 \mathrm{~Hz}), 4.41(2 \mathrm{H}, \mathrm{s}), 3.29(2 \mathrm{H}$, s), $1.63(6 \mathrm{H}, \mathrm{s}) ;{ }^{13} \mathrm{C} \delta 154.4,147.6,145.5,145.3,142.7,141.2,140.4,139.5,139.2,138.5$, $136.7,135.8,131.9,130.5,127.7,127.1,125.5,123.0,122.3,122.2,121.9,49.6,47.3,38.2$, 29.1; MS m/z $342(\mathrm{M}+), 327,312$; HRMS calcd for $\mathrm{C}_{27} \mathrm{H}_{18}$ 342.1409, found 342.1411. Recrystallization from a mixture of methylene chloride and ethanol produced a single crystal suitable for X-ray structure analysis. 
149b: IR 1448, 1365, $1217 \mathrm{~cm}^{-1} ;{ }^{1} \mathrm{H} \delta 8.68(1 \mathrm{H}, \mathrm{d}, J=7.8 \mathrm{~Hz}), 8.54(1 \mathrm{H}, \mathrm{d}, J=10.2 \mathrm{~Hz}), 8.03$ $(1 \mathrm{H}, \mathrm{d}, J=7.2 \mathrm{~Hz}), 7.96(1 \mathrm{H}, \mathrm{d}, J=7.2 \mathrm{~Hz}), 7.70-7.40(6 \mathrm{H}, \mathrm{m}), 4.24(2 \mathrm{H}, \mathrm{s}), 3.47(2 \mathrm{H}, \mathrm{s})$, $1.68(6 \mathrm{H}, \mathrm{s}) ; \mathrm{MS} m / z 344(\mathrm{M}+), 329$.

Propargylic diols 159. To a solution of 1-ethynyl-2-iodo-benzene ( $4.10 \mathrm{~g}, 0.0180 \mathrm{~mol})$ in 150 $\mathrm{mL}$ THF under a nitrogen atmosphere was added $10.8 \mathrm{~mL}$ of a $2.0 \mathrm{M}$ solution of LDA in THF/heptane/ethylbenzene $(0.0216 \mathrm{~mol})$ at $0{ }^{\circ} \mathrm{C}$. After $30 \mathrm{~min}$, a solution of diketone $(\mathbf{1 5 4}$, $2.22 \mathrm{~g}, 9.00 \mathrm{mmol}$ ) in $30 \mathrm{~mL}$ THF was added via cannula, and the reaction mixture was allowed to warm to room temperature. After an additional $12 \mathrm{~h}$ of stirring at room temperature, the reaction mixture was quenched with $50 \mathrm{~mL}$ of distilled water. THF layer was separated and water layer was extracted with diethyl ether twice. Organic layers were combined, dried over sodium sulfate, and concentrated until $20 \mathrm{~mL}$ of dark sticky black residue remain. This residue could not be purified by flash column chromatography due to its low solubility. When $50 \mathrm{~mL}$ of THF and $200 \mathrm{~mL}$ of hexanes were added to the black residue, a yellow solid was formed. This yellow solid 159 was collected by filtration. Filtrate and a dark black solid remained on the surface of glassware were combined, and concentrated to dryness. To this dry residue were added $50 \mathrm{~mL}$ of THF and $200 \mathrm{~mL}$ of hexane. After $12 \mathrm{~h}$ in the ice bath, a pale yellow solid was formed on the surface of glassware. This pale yellow solid 159 was also collected and combined with yellow solid: IR 3460, 2955, $2208 \mathrm{~cm}^{-1}$; ${ }^{1} \mathrm{H}$ NMR $\delta 7.86-7.84(2 \mathrm{H}, \mathrm{d}, J=7.2)$, $7.71(4 \mathrm{H}, \mathrm{s}), 7.47(2 \mathrm{H}, \mathrm{dd}, J=7.8$ and 1.5$), 7.30(2 \mathrm{H}, \mathrm{t}, J=7.4), 7.01(2 \mathrm{H}, \mathrm{td}, J=7.9$ and 1.5$)$, $2.43(2 \mathrm{H}, \mathrm{s}), 1.12(18 \mathrm{H}, \mathrm{s}) ;{ }^{13} \mathrm{C}$ NMR $\delta 140.9,138.7,133.1,129.5,127.7,126.6,100.3,96.0$, $87.6,79.5,39.9,25.6$. 
Diiodide 160. To a flask containing dry pale yellow solid 159 were added $100 \mathrm{~mL}$ of methylene chloride, $3.19 \mathrm{~g}$ of triethylsilane $(27.0 \mathrm{mmol})$, and $5.35 \mathrm{~mL}$ of trifluoroacetic acid $(8.21 \mathrm{~g}, 72.0 \mathrm{mmol})$. After $24 \mathrm{~h}$ of stirring at room temperature, a solution of $4.46 \mathrm{~g}$ of sodium carbonate $(36.0 \mathrm{mmol})$ in $100 \mathrm{~mL}$ of water was introduced, and extracted with diethyl ether. The combined organic extracts were dried over sodium sulfate, and concentrated. To the concentrated residue was added $50 \mathrm{~mL}$ of diethyl ether. White solid was formed and collected by filtration. Collected solid 160 was washed with diethyl ether twice. Combined filtrate was concentrated, and purified by flash column chromatography (silica gel $/ 40 \%$ diethyl ether in hexanes). White solid and column-purified product were combined to afford $1.88 \mathrm{~g}$ of $\mathbf{1 6 0}$ (7.65 mmol, 85\%): IR 2955, $2353 \mathrm{~cm}^{-1} ;{ }^{1} \mathrm{H}$ NMR $\delta 7.84(2 \mathrm{H}, \mathrm{d}, J=7.9), 7.44(2 \mathrm{H}, \mathrm{dd}, J=7.7$ and 1.5), $7.39(4 \mathrm{H}, \mathrm{s}), 7.27(2 \mathrm{H}, \mathrm{t}, J=7.4), 6.96(2 \mathrm{H}, \mathrm{t}, J=7.7), 3.68(2 \mathrm{H}, \mathrm{s}), 1.08(18 \mathrm{H}, \mathrm{s})$; ${ }^{13} \mathrm{C}$ NMR $\delta 137.4,132.5,132.0,129.0,128.4,127.2,124.5,95.9,82.8,82.0,80.7,50.2,35.5$, 27.8 .

Tetraacetylenic Hydrocarbon 162. To a flask containing $2.48 \mathrm{~g}$ of diacetylenic hydrocarbon $(160,3.70 \mathrm{mmol})$ were added $0.260 \mathrm{~g}$ of dichlorobis(triphenylphosphine)palladium $(7.40$ mmol), $0.473 \mathrm{~g}$ of $\mathrm{CuI}(2.48 \mathrm{mmol})$, and $100 \mathrm{~mL}$ of triethylamine. After $30 \mathrm{~min}$ of nitrogen flush, a solution of $1.47 \mathrm{~g}$ of 4-ethynylanisole $(\mathbf{1 6 1}, 11.1 \mathrm{mmol})$ in $10 \mathrm{~mL}$ of triethylamine was added. The resulting mixture was heated at $60^{\circ} \mathrm{C}$ for $12 \mathrm{~h}$ under a nitrogen atmosphere. After heating, the reaction mixture was allowed to cool to room temperature and was filtered to remove solid particles. Rinse the solid particles with $100 \mathrm{~mL}$ of diethyl ether. The combined filtrate was concentrated and was purified by flash column chromatography (silica gel/40\% 
diethyl ether in hexanes). This dark sticky product 162 contained byproduct, 1,4-di(p-anisol)butadiyne which could not be separated on silica gel column chromatography. 4,5-Di(4-methoxyphenyl)phenanthrene 163. To a solution of 162 in $50 \mathrm{~mL}$ of anhydrous toluene under a nitrogen atmosphere was added $5.00 \mathrm{~mL}$ of a $1.0 \mathrm{M}$ solution of potassium $t$-butoxide $(5.00 \mathrm{mmol})$ in 2-methyl-2-propanol. The reaction mixture was then heated under reflux for $12 \mathrm{~h}$. After the reaction mixture was allowed to cool to room temperature, $50 \mathrm{~mL}$ of water and $50 \mathrm{~mL}$ of diethyl ether were introduced, and then the organic layer was separated, dried over sodium sulfate, and concentrated. Purification by flash column chromatography (silica gel $/ 20 \%$ diethyl ether in hexanes) afforded $1.01 \mathrm{~g}$ of $163(1.55 \mathrm{mmol}, 42 \%$ ) as a yellow solid: ${ }^{1} \mathrm{H}$ NMR $\delta 7.81(2 \mathrm{H}, \mathrm{s}), 7.40(2 \mathrm{H}, \mathrm{d}, J=7.7 \mathrm{~Hz}), 7.06(2 \mathrm{H}, \mathrm{t}, J=7.4 \mathrm{~Hz}), 6.78(2 \mathrm{H}, \mathrm{t}$, $J=7.7 \mathrm{~Hz}), 6.58(4 \mathrm{H}, \mathrm{d}, J=8.9 \mathrm{~Hz}), 6.45(4 \mathrm{H}, \mathrm{d}, J=8.7 \mathrm{~Hz}), 6.34(2 \mathrm{H}, \mathrm{d}, J=8.2 \mathrm{~Hz}), 4.38$ $(2 \mathrm{H}, \mathrm{d}, J=22 \mathrm{~Hz}), 4.14(2 \mathrm{H}, \mathrm{d}, J=22 \mathrm{~Hz}), 3.79(6 \mathrm{H}, \mathrm{s}), 1.80(18 \mathrm{H}, \mathrm{s}) ;{ }^{13} \mathrm{C} \mathrm{NMR} \delta 158.4$, $144.2,141.2,139.0,138.8,137.2,134.6,131.9,131.8,131.7,126.0,125.3,123.7,122.8,122.0$, 55.1, 37.8, 33.4; Recrystallization of $\mathbf{1 6 3}$ from $\mathrm{CH}_{2} \mathrm{Cl}_{2}$ /ethanol produced a crystal suitable for X-ray structure analysis.

4,5-Diphenolicphenanthrene 164. To a solution of 4,5-diarylphenanthrene 163 (2.55 g, 3.76 mmol) in dry $\mathrm{CH}_{2} \mathrm{Cl}_{2} \mathrm{kept}$ in $-78{ }^{\circ} \mathrm{C}$ was added $11.3 \mathrm{~mL}$ of boron tribromide (1.0 M) under stirring. After stirring for $1 \mathrm{~h}$ at $-78^{\circ} \mathrm{C}$, the solution was allowed to reach $0{ }^{\circ} \mathrm{C}$ and stirred for 4 h. The resulting solution was warmed to room temperature and stirred for 2 more hours. The solution was cooled to $0{ }^{\circ} \mathrm{C}$ again and transferred via cannula to the stirring saturated sodium bicarbonate solution at $0^{\circ} \mathrm{C}$. The reaction mixture was thoroughly extracted with diethyl ether. 
The combined extracts were dried over sodium sulfate, and concentrated. Purification by flash column chromatography (silica gel/ from $20 \%$ diethyl ether in hexanes to $80 \%$ diethyl ether in hexanes) afforded $1.01 \mathrm{~g}$ of $\mathbf{1 6 4}(1.96 \mathrm{mmol}, 52 \%)$ as a yellow solid. This compound was not stable on standing: ${ }^{1} \mathrm{H}$ NMR $\delta 7.80(2 \mathrm{H}, \mathrm{s}), 7.39(2 \mathrm{H}, \mathrm{d}, J=7.2 \mathrm{~Hz}), 7.06(2 \mathrm{H}, \mathrm{t}, J=7.2 \mathrm{~Hz})$, $6.78(2 \mathrm{H}, \mathrm{t}, J=7.4 \mathrm{~Hz}), 6.54-6.37(10 \mathrm{H}, \mathrm{m}), 5.00(2 \mathrm{H}, \mathrm{s}), 4.38(2 \mathrm{H}, \mathrm{d}, J=21 \mathrm{~Hz}), 4.14(2 \mathrm{H}$, $\mathrm{d}, J=21 \mathrm{~Hz}), 1.80(18 \mathrm{H}, \mathrm{s})$; This compound decomposed easily, which resulted in line broadening in NMR spectra.

Camphorsulfonate 175. To a solution of $0.532 \mathrm{~g}$ of $164(0.776 \mathrm{mmol})$ in $30 \mathrm{~mL}$ of dry dichloromethane at $0{ }^{\circ} \mathrm{C}$ were added dry triethylamine $(2.33 \mathrm{mmol})$, and $0.502 \mathrm{~g}$ of (1S)-camphor-10-sulfonyl chloride $(2.00 \mathrm{mmol})$. The mixture was warmed to room temperature and stirred for $3 \mathrm{~h} .50 \mathrm{~mL}$ of water was added, and the reaction mixture was extracted with dichloromethane. The combined extracts were washed with saturated $\mathrm{NaCl}$ solution, dried over sodium sulfate, and concentrated. Purification by flash column chromatography (silica gel $/ 40 \%$ diethyl ether in hexanes) afforded $0.535 \mathrm{~g}$ of $\mathbf{1 7 5}$ (1.96 mmol, $62 \%$ ) as a yellow solid. In order to separate diastereomeric $(S)$-camphorsulfonates $\mathbf{1 7 5}, 50 \mathrm{~cm}$ of long silica gel column was prepared, and 30\% diethyl ether in hexanes was used as eluent to give diastereomerically pure $\mathbf{P - 1 7 5}$ and $\mathbf{M - 1 7 5}$.

Separated diastereomer P-175 or M-175: ${ }^{1} \mathrm{H}$ NMR $\delta 7.84(2 \mathrm{H}, \mathrm{s}), 7.38(2 \mathrm{H}, \mathrm{d}, J=7.2 \mathrm{~Hz})$, 7.09-7.02 (6 H, m), $6.74(2 \mathrm{H}, \mathrm{t}, J=8.4 \mathrm{~Hz}), 6.63(4 \mathrm{H}, \mathrm{d}, J=8.7 \mathrm{~Hz}), 6.07(2 \mathrm{H}, \mathrm{d}, J=7.7 \mathrm{~Hz})$, $4.41(2 \mathrm{H}, \mathrm{d}, J=21 \mathrm{~Hz}), 4.14(2 \mathrm{H}, \mathrm{d}, J=21 \mathrm{~Hz}), 3.86(2 \mathrm{H}, \mathrm{d}, J=15 \mathrm{~Hz}), 3.21(2 \mathrm{H}, \mathrm{d}, J=15$ Hz), 2.53-2.32 (4 H, m), 2.10-2.04 (4 H, m), 1.94 (2 H, d, J=19 Hz), 1.81 (18 H, s), 1.75-1.69 
(2H, m), 1.46-1.40 (2H, m), 1.07 (6 H, s), $0.77(6 \mathrm{H}, \mathrm{s}) ;{ }^{13} \mathrm{C} \mathrm{NMR} \delta 214.0,148.2,144.2,140.6$, $140.2,139.8,138.4,137.6,133.3,131.9,130.7,126.3,125.5,123.8,122.8,122.0,58.1,47.8$, $47.6,42.7,42.4,39.9,37.8,33.3,33.1,26.8,25.0,19.8,19.4$.

Separated diastereomer M-175 or P-175: ${ }^{1} \mathrm{H}$ NMR $\delta 7.84(2 \mathrm{H}, \mathrm{s}), 7.38(2 \mathrm{H}, \mathrm{d}, J=7.4 \mathrm{~Hz})$, 7.07-7.02 (6 H, m), $6.75(2 \mathrm{H}, \mathrm{t}, J=7.2 \mathrm{~Hz}), 6.61(4 \mathrm{H}, \mathrm{d}, J=8.7 \mathrm{~Hz}), 6.14(2 \mathrm{H}, \mathrm{d}, J=8.4 \mathrm{~Hz})$, $4.43(2 \mathrm{H}, \mathrm{d}, J=21 \mathrm{~Hz}), 4.14(2 \mathrm{H}, \mathrm{d}, J=21 \mathrm{~Hz}), 3.77(2 \mathrm{H}, \mathrm{d}, J=15 \mathrm{~Hz}), 3.21(2 \mathrm{H}, \mathrm{d}, J=15$ Hz), 2.49-2.32 (4 H, m), 2.14-2.07 (4 H, m), 1.89 (2 H, d, J=19 Hz), 1.81 (18 H, s), 1.75-1.66 (2H, m), 1.51-1.39 (2H, m), 1.15 (6 H, s), $0.86(6 \mathrm{H}, \mathrm{s}) ;{ }^{13} \mathrm{C} \mathrm{NMR} \delta 214.0,148.2,144.4,140.5$, $140.2,139.8,138.3,137.4,133.2,131.9,130.9,126.3,125.5,123.8,122.8,122.1,58.1,47.7$, $47.4,42.9,42.3,39.9,37.8,33.3,28.9,26.8,24.9,19.9,19.5$.

Hydrolyzed 4,5-diphenolicphenanthrene 164. To a $0.226 \mathrm{~g}$ of $175(0.209 \mathrm{mmol})$ in methanol $(20 \mathrm{~mL})$ was added an aqueous solution of sodium hydroxide $(2 \mathrm{M}, 5 \mathrm{~mL})$. The resulting mixture was stirred at $60{ }^{\circ} \mathrm{C}$ until TLC indicated the completion of hydrolysis. After the solution was cooled to room temperature, solvent was evaporated. The residue was extracted with dichloromethane, and evaporated to give the optically pure parent $\mathbf{1 6 4}$ as a yellow solid. Purification by flash column chromatography (silica gel/50\% diethyl ether in hexanes) afforded $0.0558 \mathrm{~g}$ of $164(0.0857 \mathrm{mmol}, 41 \%)$.

Methylated 4,5-di(4-methoxyphenyl)phenanthrene 176. To a flask containing $0.327 \mathrm{~g}$ of $163(0.482 \mathrm{mmol})$ in $30 \mathrm{~mL}$ of dry THF was added $1.50 \mathrm{~mL}$ of a $1.0 \mathrm{M}$ solution of potassium $t$-butoxide $(1.50 \mathrm{mmol})$ in 2-methyl-2-propanol. The color of the reaction mixture turned to black. After 30 min's stirring, $0.60 \mathrm{~g}$ of iodomethane (4.14 mmol) was introduced via syringe, 
and the reaction mixture was stirred for $24 \mathrm{~h}$. The color of the reaction mixture turned to white, which indicated the completion of this reaction. After $20 \mathrm{~mL}$ of water and $40 \mathrm{~mL}$ of diethyl ether were introduced, organic layer was separated, dried over sodium sulfate, and concentrated. The residue was purified by flash column chromatography to afford $0.298 \mathrm{~g}$ of $176(0.439 \mathrm{mmol}, 91 \%)$ as a yellow solid (silica gel $/ 20 \%$ diethyl ether in hexanes): ${ }^{1} \mathrm{H}$ NMR $\delta$ $7.97(2 \mathrm{H}, \mathrm{s}), 7.32(2 \mathrm{H}, \mathrm{d}, J=7.4 \mathrm{~Hz}), 7.04(2 \mathrm{H}, \mathrm{t}, J=7.4 \mathrm{~Hz}), 6.76(2 \mathrm{H}, \mathrm{t}, J=7.9 \mathrm{~Hz})$, 6.53-6.43 (10 H, m), $4.71(2 \mathrm{H}, \mathrm{q}, J=6.7 \mathrm{~Hz}), 3.74(6 \mathrm{H}, \mathrm{s}), 1.87(18 \mathrm{H}, \mathrm{s}), 1.59(6 \mathrm{H}, \mathrm{d}, 6.7 \mathrm{~Hz})$; ${ }^{13} \mathrm{C}$ NMR $\delta 158.6,151.1,147.1,139.4,137.5,135.0,134.9,134.0,133.9,131.3,131.0,126.0$, $125.3,123.1,122.9,122.4,112.5,55.1,44.2,38.1,34.5,27.2$; Recrystallization of $\mathbf{1 7 6}$ from $\mathrm{CH}_{2} \mathrm{Cl}_{2}$ /ethanol produced a crystal suitable for X-ray structure analysis.

Methylated 4,5-diphenolicphenanthrene 177. The same procedure was repeated as described for 164 except that $0.109 \mathrm{~g}$ of methylated 4,5-di(4-methoxyphenyl)phenanthrene $176(0.154 \mathrm{mmol})$ was treated with $0.326 \mathrm{~mL}$ of $1 \mathrm{M}$ boron tribromide to afford $0.0506 \mathrm{~g}$ of $177(0.074 \mathrm{mmol}, 48 \%)$ as a yellow solid: ${ }^{1} \mathrm{H} \operatorname{NMR} \delta 7.97(2 \mathrm{H}, \mathrm{s}), 7.32(2 \mathrm{H}, \mathrm{d}, J=7.2 \mathrm{~Hz})$, $7.04(2 \mathrm{H}, \mathrm{t}, J=7.4 \mathrm{~Hz}), 6.77(2 \mathrm{H}, \mathrm{t}, J=7.9 \mathrm{~Hz}), 6.61-6.43(10 \mathrm{H}, \mathrm{m}), 4.71(2 \mathrm{H}, \mathrm{q}, 6.7 \mathrm{~Hz})$, $4.55(2 \mathrm{H}, \mathrm{s}), 1.86(18 \mathrm{H}, \mathrm{s}), 1.59(6 \mathrm{H}, \mathrm{d}, 6.7 \mathrm{~Hz}) ;{ }^{13} \mathrm{C} \mathrm{NMR} \delta 154.5,151.0,147.1,139.3,137.6$, $135.0,134.8,134.1,133.9,131.6,131.0,126.1,125.3,123.1,122.9,122.4,114.1,44.2,38.1$, $34.5,27.2$.

4,5-Di(3-methoxyphenyl)phenanthrene 195. The same procedure was repeated as described for 163 except that $6.34 \mathrm{~g}$ of diiodide $160(9.45 \mathrm{mmol})$ and $3.75 \mathrm{~g}$ of 3-ethynylanisole (192) (28.4 mmol) were treated with $0.66 \mathrm{~g}$ of dichlorobis(triphenylphosphine) palladium $(0.94$ 
$\mathrm{mmol})$ and $0.33 \mathrm{~g}$ of $\mathrm{CuI}(1.73 \mathrm{mmol})$, and $100 \mathrm{~mL}$ of triethylamine. For cyclization step, 14.0 $\mathrm{mL}$ of a 1.0 M solution of potassium $t$-butoxide $(14.0 \mathrm{mmol})$ in 2-methyl-2-propanol was used. Purification by flash column chromatography (silica gel/20\% diethyl ether in hexanes) afforded $3.02 \mathrm{~g}$ of 195 (1.55 mmol, 37\%) as a yellow solid.

Methylated 4,5-di(3-methoxyphenyl)phenanthrene 196. Methylation step was repeated as described for 176 except that $1.48 \mathrm{~g}$ of 195 (2.18 mmol), $5.0 \mathrm{~mL}$ of a $1.0 \mathrm{M}$ solution of potassium $t$-butoxide $(5.00 \mathrm{mmol})$ in 2-methyl-2-propanol, and $1.20 \mathrm{~g}$ of iodomethane $(8.28$ mmol) were introduced in sequence to furnish $0.298 \mathrm{~g}$ of $196(0.439 \mathrm{mmol}, 91 \%)$ as a yellow solid (silica gel/20\% diethyl ether in hexanes): ${ }^{1} \mathrm{H}$ NMR $\delta 7.97(2 \mathrm{H}, \mathrm{s}), 7.32(2 \mathrm{H}, \mathrm{d}, J=7.4$ Hz), $7.04(2 \mathrm{H}, \mathrm{t}, J=7.4 \mathrm{~Hz}), 6.76(2 \mathrm{H}, \mathrm{t}, J=7.9 \mathrm{~Hz}), 6.53-6.43(10 \mathrm{H}, \mathrm{m}), 4.71(2 \mathrm{H}, \mathrm{q}, J=6.7$ Hz), 3.74 (6 H, s), 1.87 (18 H, s), 1.59 (6 H, d, $6.7 \mathrm{~Hz}) ;{ }^{13} \mathrm{C}$ NMR $\delta 158.4,151.1,147.0,139.4$, $139.0,138.0,135.5,134.9,134.0,131.1,128.0,126.2,125.6,125.3,123.4,122.5,122.4,116.5$, 144.0, 54.7, 44.2, 38.1, 34.5, 27.2 .

4,5-Di(2-methoxyphenyl)phenanthrene 198. The same procedure was repeated as described for $\mathbf{1 6 3}$ except that $2.88 \mathrm{~g}$ of diiodide $160(4.30 \mathrm{mmol})$ and $1.70 \mathrm{~g}$ of 2-ethynylanisole (12.9 mmol) were treated with $0.33 \mathrm{~g}$ of dichlorobis(triphenylphosphine)palladium $(0.47 \mathrm{mmol})$ and $0.17 \mathrm{~g}$ of $\mathrm{CuI}(0.87 \mathrm{mmol})$, and $100 \mathrm{~mL}$ of triethylamine. For cyclization step, $13.0 \mathrm{~mL}$ of a 1.0 $\mathrm{M}$ solution of potassium $t$-butoxide $(13.0 \mathrm{mmol})$ in 2-methyl-2-propanol was used. Purification by flash column chromatography (silica gel/20\% diethyl ether in hexanes) afforded $1.08 \mathrm{~g}$ of $\mathbf{1 9 8}(1.59 \mathrm{mmol}, 37 \%)$ as a yellow solid. Generated three isomers could not be separated on silica gel column chromatography: ${ }^{1} \mathrm{H}$ NMR $\delta 7.81,7.80(2 \mathrm{H}, \mathrm{s}, \mathrm{s}), 7.37,7.36$ 
(2 H, d, d, J= 7.4 Hz), 7.24-7.11 (2 H, m), 7.07-6.99 (2 H, m), 6.83-6.68 (2 H, m), 6.67-6.50 (4 H, m), 6.47-6.40 (2 H, m), 6.26, 6.09, 6.04, $5.75(2 \mathrm{H}, \mathrm{d}, \mathrm{d}, \mathrm{d}, \mathrm{d}, J=8.2 \mathrm{~Hz}), 4.37,4.34(2 \mathrm{H}, \mathrm{d}$, $\mathrm{d}, J=21 \mathrm{~Hz}), 4.12,4.11,4.09(2 \mathrm{H}, \mathrm{d}, \mathrm{d}, \mathrm{d}, J=21 \mathrm{~Hz}), 3.12,3.09,3.07(6 \mathrm{H}, \mathrm{s}, \mathrm{s}, \mathrm{s}), 1.82,1.80$, $1.78(18 \mathrm{H}, \mathrm{s}, \mathrm{s}, \mathrm{s}) ;{ }^{13} \mathrm{C}$ NMR $\delta 159.1,156.1,155.3,144.2,144.1,143.3,142.2,141.5,141.4$, $139.4,139.1,139.0,138.9,138.7,138.5,137.7,137.2,136.8,136.1,135.2,134.6,134.0,133.2$, $132.2,131.9,131.3,131.2,131.0,130.4,130.0,129.0,128.7,128.2,128.1,128.0,127.2,125.7$, $125.3,123.5,123.3,123.2,122.2,122.0,121.8,121.7,121.1,120.9,119.5,111.0,110.5,110.3$, $54.8,54.6,54.0,39.9,39.8,37.9,37.8,37.7,33.6,33.5,33.4$.

4,5-Di(4-aminophenyl)phenanthrene 201. The same procedure was repeated as described for 162 except that $6.22 \mathrm{~g}$ of $\mathbf{1 6 0}(9.28 \mathrm{mmol})$ and $2.18 \mathrm{~g}$ of 4-ethynylaniline $199(18.6 \mathrm{mmol})$ were treated with $0.66 \mathrm{~g}$ of dichlorobis(triphenylphosphine)palladium $(0.94 \mathrm{mmol})$ and $0.33 \mathrm{~g}$ of $\mathrm{CuI}(1.74 \mathrm{mmol})$, and $100 \mathrm{~mL}$ of triethylamine. For cyclization step, $23.0 \mathrm{~mL}$ of a $1.0 \mathrm{M}$ solution of potassium $t$-butoxide $(23.0 \mathrm{mmol})$ in 2-methyl-2-propanol was used. Purification by flash column chromatography (silica gel $/ 50 \%$ diethyl ether in hexanes to $100 \%$ ether) afforded $1.32 \mathrm{~g}$ of 201 (1.59 mmol, 22\%) as a yellow solid: IR 3368, 2949, $2214 \mathrm{~cm}^{-1}$; ${ }^{1} \mathrm{H}$ NMR $\delta 7.80(2 \mathrm{H}, \mathrm{s}), 7.40(2 \mathrm{H}, \mathrm{d}, J=7.2 \mathrm{~Hz}), 7.07(2 \mathrm{H}, \mathrm{t}, J=7.2 \mathrm{~Hz}), 6.82(2 \mathrm{H}, \mathrm{t}, J=7.4 \mathrm{~Hz})$, $6.56(2 \mathrm{H}, \mathrm{d}, J=7.9 \mathrm{~Hz}), 6.41(8 \mathrm{H}, \mathrm{s}), 4.38(2 \mathrm{H}, \mathrm{d}, J=21 \mathrm{~Hz}), 4.15(2 \mathrm{H}, \mathrm{d}, J=21 \mathrm{~Hz}), 3.80$ (4 H, s), $1.81(18 \mathrm{H}, \mathrm{s}) ;{ }^{13} \mathrm{C}$ NMR $\delta 144.8,144.1,141.5,139.1,138.7,137.0,135.4,131.7$, $129.7,125.8,125.3,123.5,123.8,123.1,114.8,37.7,33.4,33.3$.

Sulfonamide 202. The same procedure was repeated as described for $\mathbf{1 7 5}$ except that $1.22 \mathrm{~g}$ of 201 (1.87 mmol) was treated with dry triethylamine $(5.61 \mathrm{mmol})$ and $1.20 \mathrm{~g}$ of 
(1S)-camphor-10-sulfonyl chloride $(5.61 \mathrm{mmol})$ to afford $1.86 \mathrm{~g}$ of $\mathbf{2 0 2}(1.68 \mathrm{mmol}, 90 \%)$ as a yellow solid. The same separation method was employed to give diastereomerically pure M-202 and P-202 except for the use of 40\% diethyl ether in hexanes as eluent.

Diastereomer P-202 or M-202: ${ }^{1} \mathrm{H}$ NMR $\delta 7.85(2 \mathrm{H}, \mathrm{s}), 7.33(2 \mathrm{H}, \mathrm{d}, J=7.4 \mathrm{~Hz}), 7.17(4 \mathrm{H}, \mathrm{d}$, $J=8.7 \mathrm{~Hz}), 7.02(2 \mathrm{H}, \mathrm{t}, J=7.4 \mathrm{~Hz}), 6.80(2 \mathrm{H}, \mathrm{t}, J=7.7 \mathrm{~Hz}), 6.72(2 \mathrm{H}, \mathrm{d}, J=7.2 \mathrm{~Hz}), 6.62(2$ H, d, $J=7.2 \mathrm{~Hz}), 6.29(2 \mathrm{H}, \mathrm{d}, J=8.2 \mathrm{~Hz}), 4.45(2 \mathrm{H}, \mathrm{d}, J=21 \mathrm{~Hz}), 4.12(2 \mathrm{H}, \mathrm{d}, J=21 \mathrm{~Hz})$, 4.00-3.62 (4 H, m), 2.46-2.22 (4 H, m), 2.14-1.95 (4 H, m), $1.83(18 \mathrm{H}, \mathrm{s}), 1.40-1.38(2 \mathrm{H}, \mathrm{m})$, 1.25-1.24 (2 H, m), 1.50-1.32 (2 H, m), $1.15(6 \mathrm{H}, \mathrm{s}), 0.90(6 \mathrm{H}, \mathrm{s}) ;{ }^{13} \mathrm{C} \mathrm{NMR} \delta 219.0,144.5$, $140.9,140.3,140.1,140.0,137.1,135.6,133.5,132.3,131.8,131.3,131.1,130.2,126.2,125.7$, $123.4,123.1,122.1,59.1,58.9,53.0,52.2,47.9,47.4,42.9,42.7,42.4,42.3,39.8,37.9,33.4$, $26.9,25.1,20.3,20.1,19.7$.

Diastereomer P-202 or M-202: ${ }^{1} \mathrm{H}$ NMR $\delta 7.86(2 \mathrm{H}, \mathrm{s}), 7.54(2 \mathrm{H}, \mathrm{d}, J=8.9 \mathrm{~Hz}), 7.17(4 \mathrm{H}, \mathrm{d}$, $J=7.2 \mathrm{~Hz}), 7.20(2 \mathrm{H}, \mathrm{d}, J=7.9 \mathrm{~Hz}), 6.99(2 \mathrm{H}, \mathrm{t}, J=7.7 \mathrm{~Hz}), 6.73-6.68(6 \mathrm{H}, \mathrm{m}), 6.02(2 \mathrm{H}, \mathrm{d}$, $J=8.2 \mathrm{~Hz}), 4.38(2 \mathrm{H}, \mathrm{d}, J=21 \mathrm{~Hz}), 4.20-4.09(4 \mathrm{H}, \mathrm{m}), 3.76(2 \mathrm{H}, \mathrm{d}, J=14 \mathrm{~Hz}), 3.60(2 \mathrm{H}, \mathrm{d}$, $J=15 \mathrm{~Hz}), 2.50-2.31(4 \mathrm{H}, \mathrm{m}), 2.13-1.86(4 \mathrm{H}, \mathrm{m}), 1.81(18 \mathrm{H}, \mathrm{s}), 1.96-1.86(2 \mathrm{H}, \mathrm{m})$, 1.69-1.62 (2 H, m), 1.40-1.29 (2 H, m), $1.14(6 \mathrm{H}, \mathrm{s}), 0.88(6 \mathrm{H}, \mathrm{s}) ;{ }^{13} \mathrm{C} \mathrm{NMR} \delta 219.0,144.5$, $140.9,140.3,140.1,140.0,137.1,135.6,133.5,132.3,131.8,131.3,131.1,130.2,126.2,125.7$, $123.4,123.1,122.1,59.0,58.9,53.0,52.3,47.9,47.4,42.9,42.7,42.4,42.3,39.8,37.9,33.4$, $26.9,25.1,20.4,20.2,19.7$.

2-(1,3-Dimethoxypropyl)-1,3-indandione (234). In an ordinary glassware equipped with a magnetic stirring bar, $15 \mathrm{~mL}$ of DMSO was added to $1.70 \mathrm{~g}$ of 1,3-dimethoxyacetone (15.0 
$\mathrm{mmol}), 2.19 \mathrm{~g}$ of 1,3-indandione (15.0 mmol) and $3.81 \mathrm{~g}$ of Hantzsch ester(15.0 mmol). $0.35 \mathrm{~g}$ of L-proline $(3.00 \mathrm{mmol})$ was then added and the reaction mixture was stirred at room temperature for $24 \mathrm{~h}$. The reaction mixture was directly loaded onto a silica gel column without work-up, and $3.05 \mathrm{~g}$ of yellowish green liquid (12.3 mmol, $82 \%)$ was obtained by silica gel column chromatography ( silica gel $/ 20 \%$ diethyl ether in hexanes, $R_{f}=0.48$ (hexanes:diethyl ether $=4: 6)$ ): IR 2928, 2354, $1709 \mathrm{~cm}^{-1} ;{ }^{1} \mathrm{H}$ NMR $\delta$ 7.96-7.77 (m, $4 \mathrm{H}$, indanyl aromatic $\left.\mathrm{H}\right)$, $3.48(4 \mathrm{H}, \mathrm{d}, J=7.2 \mathrm{~Hz}), 3.14(1 \mathrm{H}, \mathrm{d}, J=2.7 \mathrm{~Hz}), 3.09(6 \mathrm{H}, \mathrm{s}), 3.03(1 \mathrm{H}, \mathrm{m}) ;{ }^{13} \mathrm{C} \mathrm{NMR} \delta$ 199.8, 142.3, 134.9, 122.7, 71.0, 58.5, 52.1, 39.6; HRMS calcd for $\mathrm{C}_{14} \mathrm{H}_{16} \mathrm{O}_{4}\left(\mathrm{MH}^{+}\right)$249.11214, found 249.11213 .

2-Methyl-2-(1.3-dimethoxypropyl)-1,3-indandione (232). To a flask containing $2.08 \mathrm{~g}$ of $234(8.39 \mathrm{mmol})$ in $20 \mathrm{~mL}$ of THF under a nitrogen atmosphere was added $16.0 \mathrm{~mL}$ of $1.0 \mathrm{M}$ solution of potassium $t$-butoxide $(16.0 \mathrm{mmol})$ in 2-methyl-2-propanol. After $30 \mathrm{~min}$ of stirring, $4.64 \mathrm{~g}$ of iodomethane $(32.0 \mathrm{mmol})$ was introduced via syringe, and the reaction mixture was stirred for 48 h. $20 \mathrm{~mL}$ of water and $40 \mathrm{~mL}$ of diethyl ether were introduced, and organic layer was separated, dried over sodium sulfate, and concentrated. The residue was purified by flash column chromatography ( $15 \%$ diethyl ether in hexanes, $R_{f}=0.41$ (hexanes:diethyl ether $\left.=4: 6\right)$ ) to furnish $1.72 \mathrm{~g}$ of yellowish green liquid (6.54 mmol, 78\%): IR 2925, 2340, $1706 \mathrm{~cm}^{-1} ;{ }^{1} \mathrm{H}$ NMR $\delta 7.97-7.79(\mathrm{~m}, 4 \mathrm{H}$, indanyl aromatic $\mathrm{H}), 3.55(2 \mathrm{H}, \mathrm{dd}, J=9.9$ and $5.4 \mathrm{~Hz}), 3.43(2 \mathrm{H}$, $\mathrm{dd}, J=9.8$ and $6.7 \mathrm{~Hz}), 3.01(6 \mathrm{H}, \mathrm{s}), 2.53(1 \mathrm{H}, \mathrm{m}), 1.32(3 \mathrm{H}, \mathrm{s}) ;{ }^{13} \mathrm{C} \mathrm{NMR} \delta 203.3,140.9$, 135.1, 123.0, 70.1, 58.4, 53.3, 44.7, 18.5; HRMS calcd for $\mathrm{C}_{15} \mathrm{H}_{18} \mathrm{O}_{4}\left(\mathrm{MH}^{+}\right)$263.12779, found 263.12773. 
Propargylic diols 235. To a flask containing 4.11 g of 1-(2-ethynylphenyl)-2-phenylethyne (20.0 mmol) in $50 \mathrm{~mL}$ of THF under a nitrogen atmosphere at $0{ }^{\circ} \mathrm{C}$ was added $12.5 \mathrm{~mL}$ of 1.6 M solution of $n$-butyl lithium. After $30 \mathrm{~min}$ of stirring, a solution of $1.49 \mathrm{~g}$ of 232 (5.69 mmol) in $20 \mathrm{~mL}$ of THF was introduced via cannula, and the reaction mixture was allowed to cool to room temperature. After additional $5 \mathrm{~h}, 50 \mathrm{~mL}$ of water was added, and then the reaction mixture was extracted with diethyl ether. The combined organic extracts were washed with water, dried over sodium sulfate, and concentrated. The residue was purified by flash column chromatography (silica gel $/ 70 \%$ diethyl ether in hexanes, $R_{f}=0.37$ (hexanes:diethyl ether $=$ 4:6) to furnish $3.54 \mathrm{~g}$ of sticky brown liquid (5.29 mmol, 93\%): IR 3493, 2927, $2355 \mathrm{~cm}^{-1} ;{ }^{1} \mathrm{H}$ NMR $\delta 7.75(1 \mathrm{H}, \mathrm{d}, J=7.4 \mathrm{~Hz}), 7.60-7.38(6 \mathrm{H}, \mathrm{m}), 7.35-7.18(15 \mathrm{H}, \mathrm{m}), 5.09(1 \mathrm{H}, \mathrm{s}), 4.81(1$ H, s), $4.13(1 \mathrm{H}, \mathrm{dd}, J=9.5$ and $5.7 \mathrm{~Hz}), 3.59-3.50(2 \mathrm{H}, \mathrm{m}), 3.39(3 \mathrm{H}, \mathrm{s}), 3.31(3 \mathrm{H}, \mathrm{s})$, 3.33-3.29 (2 H, m), $1.15(3 \mathrm{H}, \mathrm{s}) ;{ }^{13} \mathrm{C}$ NMR $\delta 143.7,142.6,132.2,132.2,132.0,131.8,131.7$, $129.8,128.9,128.4,128.3,128.2,128.1,128.0,127.8,127.7,125.6,125.2,125.2,123.7,123.1$, $122.9,96.1,94.2,93.1,93.0,88.2,88.1,87.7,84.5,81.0,79.4,72.0,61.1,59.0,58.3,40.6$, 15.0; HRMS calcd for $\mathrm{C}_{47} \mathrm{H}_{38} \mathrm{O}_{4}\left(\mathrm{MH}^{+}\right)$667.28429, found 667.28676.

Dimethoxy compound 236. To $1.20 \mathrm{~g}$ of trans-diol $235(1.80 \mathrm{mmol})$ in $50 \mathrm{~mL}$ of THF at $0{ }^{\circ} \mathrm{C}$ was added via cannula a solution of thionyl chloride (1.04 g, $8.74 \mathrm{mmol})$ and anhydrous pyridine (1.38 $\mathrm{g}, 17.4 \mathrm{mmol})$ in $20 \mathrm{~mL}$ of THF. The reaction mixture was allowed to warm to room temperature. After an additional $8 \mathrm{~h}$, reaction mixture was cooled down to $0{ }^{\circ} \mathrm{C}$, and transferred via cannula to $50 \mathrm{~mL}$ of sirring ice water. The reaction mixture was extracted with $50 \mathrm{~mL}$ of benzene. The combined organic extracts were washed with water, dried over sodium 
sulfate, and concentrated to furnish the crude dichloride. To a flask containing AIBN $(0.0327 \mathrm{~g}$, $0.200 \mathrm{mmol})$ were added the crude in $40 \mathrm{~mL}$ of benzene and tributyltin hydride $(1.51 \mathrm{~mL}, 5.30$ mmol). The reaction mixture was heated under reflux for $18 \mathrm{~h}$ under oxygen free condition. After the reaction mixture was allowed to cool to room temperature, $30 \mathrm{~mL}$ of a $10 \%$ aqueous potassium fluoride solution was introduced. The mixture was stirred for an additional $5 \mathrm{~h}$ and filtered. The organic layer was separated, washed with water, dried over sodium sulfate, and concentrated to give a brown solid residue. The residue was purified by flash column chromatography (silica gel $/ 30 \%$ diethyl ether in hexanes, $R_{f}=0.58$ (hexanes: diethyl ether $=$ 4:6)) to afford $0.46 \mathrm{~g}$ of $236(0.72 \mathrm{mmol}, 40 \%)$ as a yellow solid of which the solubility in diethyl ether was quite low: IR 3059, 2927, $2345 \mathrm{~cm}^{-1} ;{ }^{1} \mathrm{H}$ NMR $\delta$ 7.64-7.54 (10 H, m), 7.46-7.43 (2 H, m), $7.39(2 \mathrm{H}, \mathrm{s}), 7.26(2 \mathrm{H}, \mathrm{t}, J=7.2 \mathrm{~Hz}), 7.07(2 \mathrm{H}, \mathrm{t}, J=7.4 \mathrm{~Hz}), 6.70(2 \mathrm{H}$, $\mathrm{d}, J=7.9 \mathrm{~Hz}), 4.36(2 \mathrm{H}, \mathrm{d}, J=23.0 \mathrm{~Hz}), 4.30(2 \mathrm{H}, \mathrm{d}, J=23.2 \mathrm{~Hz}), 3.56(2 \mathrm{H}, \mathrm{dd}, J=4.7$ and $5.2 \mathrm{~Hz}), 3.38(2 \mathrm{H}, \mathrm{dd}, J=6.7$ and $9.5 \mathrm{~Hz}), 3.25(1 \mathrm{H}, \mathrm{m}), 3.21(6 \mathrm{H}, \mathrm{s}), 2.05(3 \mathrm{H}, \mathrm{s}) ;{ }^{13} \mathrm{C} \mathrm{NMR}$ $\delta 144.6,143.7,141.9,139.3,138.6,135.5,135.5,132.1,130.1,130.1,128.9,127.7,126.9$, $126.5,126.5,126.5,124.8,123.6,123.4,72.4,58.7,56.6,46.3,35.3,20.2$; HRMS calcd for $\mathrm{C}_{47} \mathrm{H}_{38} \mathrm{O}_{2}\left(\mathrm{MH}^{+}\right)$634.28720, found 634.28603.

Dibromide 231. To a flask containing $236(0.15 \mathrm{~g}, 0.24 \mathrm{mmol})$ in $50 \mathrm{~mL}$ of dry $\mathrm{CH}_{2} \mathrm{Cl}_{2}$ kept in $-78{ }^{\circ} \mathrm{C}$ was added $0.58 \mathrm{~mL}$ of boron tribromide $(1.0 \mathrm{M})$. After stirring for $5 \mathrm{~h}$ at $-78{ }^{\circ} \mathrm{C}$, the solution was allowed to reach $0{ }^{\circ} \mathrm{C}$ and stirring for $8 \mathrm{~h}$. The resulting solution was warmed to room temperature and stirred for more than $2 \mathrm{~h}$. The solution was cooled to $0{ }^{\circ} \mathrm{C}$ again and transferred via cannula to the stirring saturated sodium bicarbonate solution at $0{ }^{\circ} \mathrm{C}$. The 
reaction mixture was thoroughly extracted with diethyl ether. The combined extracts were dried over sodium sulfate, and concentrated. Purification by flash column chromatography (silica gel/from 50\% diethyl ether in hexanes to $100 \%$ acetone) afforded a yellow sticky liquid 237. To a flask containing alcohol 237 were added $0.19 \mathrm{~g}$ of triphenylphosphine (0.72 mmol), $0.24 \mathrm{~g}$ of carbon tetrabromide $(0.72 \mathrm{mmol})$, and $30 \mathrm{~mL}$ of dry dichloromethane. The reaction mixture was stirred at room temperature for $48 \mathrm{~h}$. After the reaction mixture was concentrated, the residue was purified by flash column chromatography (silica gel/10\% diethyl ether in hexanes, $R_{f}=0.75$ (hexanes:diethyl ether $\left.\left.=6.5: 3.5\right)\right)$ to afford $0.060 \mathrm{~g}$ of $231(0.082 \mathrm{mmol}$, 34\%) as a yellow solid: IR 3057, 2926, $2247 \mathrm{~cm}^{-1} ;{ }^{1} \mathrm{H}$ NMR $\delta$ 7.64-7.56 (10 H, m), 7.43-7.41 $(2 \mathrm{H}, \mathrm{m}), 7.39(2 \mathrm{H}, \mathrm{s}), 7.26(2 \mathrm{H}, \mathrm{t}, J=7.4 \mathrm{~Hz}), 7.06(2 \mathrm{H}, \mathrm{t}, J=7.4 \mathrm{~Hz}), 6.70(2 \mathrm{H}, \mathrm{d}, J=7.9$ $\mathrm{Hz}), 4.34(2 \mathrm{H}, \mathrm{d}, J=21.0 \mathrm{~Hz}), 4.24(2 \mathrm{H}, \mathrm{d}, J=22.0 \mathrm{~Hz}), 3.93-3.90(2 \mathrm{H}, \mathrm{m}), 3.58-3.56(3 \mathrm{H}$, m), $2.13(3 \mathrm{H}, \mathrm{s}) ;{ }^{13} \mathrm{C}$ NMR $\delta 143.1,142.6,141.7,139.6,138.3,135.5,132.9,130.1,129.9$, $129.0,129.0,127.8,127.2,126.8,126.7,124.8,123.9,123.6,58.3,50.6,35.4,33.2,20.7$; HRMS calcd for $\mathrm{C}_{45} \mathrm{H}_{32} \mathrm{Br}_{2}$ 759.05288, found 759.05558.

2-Tetrahydropyranyl-1,3-indandione (244). The same procedure was repeated as described for 234 except $0.50 \mathrm{~g}$ of tetrahydro-4H-pyran-4-one (5.00 mmol), $0.73 \mathrm{~g}$ of 1,3-Indandione (5.00 mmol), $1.27 \mathrm{~g}$ of Hantzsch ester $(5.00 \mathrm{mmol})$, and $0.12 \mathrm{~g}$ of L-proline $(1.00 \mathrm{mmol})$ were used to furnish 244. $0.921 \mathrm{~g}$ of yellow solid product (4.00 mmol, 80\%) was obtained by silica gel column chromatography $\left(20 \%\right.$ diethyl ether in hexanes, $R_{f}=0.43$ (hexanes:diethyl ether $=$ 4:6)): IR 2956, 2105, $1705 \mathrm{~cm}^{-1} ;{ }^{1} \mathrm{H}$ NMR $\delta$ 7.99-7.83 (m, $4 \mathrm{H}$, indanyl aromatic H), 3.94 (2 H, $\mathrm{dd}, J=7.2$ and $3.7 \mathrm{~Hz}), 3.36(2 \mathrm{H}, \mathrm{td}, J=11.9$ and $2.0 \mathrm{~Hz}), 2.90(1 \mathrm{H}, \mathrm{d}, J=3.9 \mathrm{~Hz}), 2.51-2.40$ 
(1 H, m), 1.92-1.77 (2 H,m), 1.51-1.46 (2 H, d, $J=12.6 \mathrm{~Hz}) ;{ }^{13} \mathrm{C}$ NMR $\delta 200.4,142.7,135.7$, 123.0, 67.9, 57.5, 36.1, 29.5; HRMS calcd for $\mathrm{C}_{14} \mathrm{H}_{14} \mathrm{O}_{3}\left(\mathrm{MH}^{+}\right)$231.10157, found 231.10158. 2-Methyl-2-tetrahydropyranyl-1,3-indandione (245). The same procedure was repeated as described for 232 except that $0.16 \mathrm{~g}(0.69 \mathrm{mmol})$ of 244 in $20 \mathrm{~mL}$ of THF, $1.40 \mathrm{~mL}$ of a $1.0 \mathrm{M}$ solution of potassium $t$-butoxide $(1.40 \mathrm{mmol})$ in 2-methyl-2-propanol, and $0.20 \mathrm{~g}$ of iodomethane $(1.38 \mathrm{mmol})$ were used to furnish $\mathbf{2 4 5}$. The residue was purified by flash column chromatography (silica gel/15\% diethyl ether in hexanes, $R_{f}=0.57$ (hexanes:diethyl ether $=$ 4:6)) to give $0.13 \mathrm{~g}$ of yellow solid product ( $0.54 \mathrm{mmol}, 78 \%)$ : IR $2933,2338,1703 \mathrm{~cm}^{-1} ;{ }^{1} \mathrm{H}$ NMR $\delta$ 7.98-7.83 (m, $4 \mathrm{H}$, indanyl aromatic H), $3.92(2 \mathrm{H}, \mathrm{dd}, J=10.9$ and $4.0 \mathrm{~Hz}), 3.29(2 \mathrm{H}$, td, $J=11.9$ and $2.5 \mathrm{~Hz}), 2.15-2.03(1 \mathrm{H}, \mathrm{m}), 1.64-1.43(4 \mathrm{H}, \mathrm{m}), 1.28(3 \mathrm{H}, \mathrm{s}) ;{ }^{13} \mathrm{C} \mathrm{NMR} \delta$ 204.2, 141.4, 135.8, 123.0, 67.9, 55.8, 41.0, 27.8, 16.4; HRMS calcd for $\mathrm{C}_{15} \mathrm{H}_{16} \mathrm{O}_{3}\left(\mathrm{MH}^{+}\right)$ 245.11722, found 245.11726.

Propargylic diols 246. The same procedure was repeated as described for $\mathbf{2 3 5}$ except that 1.12 $\mathrm{g}$ of 1-(2-ethynylphenyl)-2-phenylethyne $(5.60 \mathrm{mmol})$ in $50 \mathrm{~mL}$ of $\mathrm{THF}, 3.50 \mathrm{~mL}$ of $1.6 \mathrm{M}$ solution of $n$-butyl lithium, and $0.35 \mathrm{~g}$ of $245(1.43 \mathrm{mmol})$ in $20 \mathrm{~mL}$ of THF were used to furnish 246. The residue was purified by flash column chromatography (silica gel/70\% diethyl ether in hexanes, $R_{f}=0.40$ (hexanes:diethyl ether $\left.=4: 6\right)$ to give $0.825 \mathrm{~g}$ of $246(1.27 \mathrm{mmol}$, 89\%): IR 3343, 2956, $2248 \mathrm{~cm}^{-1} ;{ }^{1} \mathrm{H}$ NMR $\delta 7.73(1 \mathrm{H}, \mathrm{d}, J=7.4 \mathrm{~Hz}), 7.58-7.50(4 \mathrm{H}, \mathrm{m})$, 7.43-7.23 (16 H, m), $7.15(1 \mathrm{H}, \mathrm{td}, J=7.4$ and $1.0 \mathrm{~Hz}), 3.92(1 \mathrm{H}, \mathrm{dd}, J=10.9$ and $3.5 \mathrm{~Hz}), 3.83$ $(1 \mathrm{H}, \mathrm{dd}, J=10.9$ and $3.7 \mathrm{~Hz}), 3.49(1 \mathrm{H}, \mathrm{t}, J=10.2 \mathrm{~Hz}), 3.30(1 \mathrm{H}, \mathrm{t}, J=11.6 \mathrm{~Hz}), 3.05-3.01$ $(1 \mathrm{H}, \mathrm{m}), 2.27(1 \mathrm{H}, \mathrm{d}, J=13.6 \mathrm{~Hz}), 2.05(1 \mathrm{H}, \mathrm{d}, J=11.9 \mathrm{~Hz}), 1.81-1.61(2 \mathrm{H}, \mathrm{m}), 1.17(3 \mathrm{H}$, 
$\mathrm{s}) ;{ }^{13} \mathrm{C}$ NMR $\delta 144.3,143.2,132.2,132.1,132.0,131.8,131.6,130.1,129.4,128.5,128.4$, $128.3,127.9,125.7,125.6,124.9,124.7,124.2,123.5,122.9,122.6,94.3,93.4,93.1,88.0$, 87.6, 86.4, 80.2, 79.8, 68.4, 68.3, 61.7, 38.0, 28.9, 28.3; HRMS calcd for $\mathrm{C}_{47} \mathrm{H}_{36} \mathrm{O}_{3}\left(\mathrm{MH}^{+}\right)$ 649.27372, found 649.27404.

Tetrahydropyranyl compound $\mathbf{2 4 2}$. The same procedure was repeated as described for $\mathbf{2 3 6}$ except that $1.30 \mathrm{~g}$ of trans-diol $246(2.00 \mathrm{mmol})$ in $50 \mathrm{~mL}$ of THF, a solution of thionyl chloride (1.19 g, $9.99 \mathrm{mmol})$ and anhydrous pyridine $(1.58 \mathrm{~g}, 20.0 \mathrm{mmol})$ in $20 \mathrm{~mL}$ of THF were used to furnish the crude dichloride. AIBN (0.0327 g, $0.200 \mathrm{mmol})$, tributyltin hydride (1.61 $\mathrm{mL}, 5.65 \mathrm{mmol})$ were added to the crude dichloride. The reaction mixture was heated under reflux for $18 \mathrm{~h}$. The residue was purified by flash column chromatography (silica gel $/ 30 \%$ diethyl ether in hexanes, $R_{f}=0.77$ (hexanes:diethyl ether $\left.=4: 6\right)$ ) to afford $0.493 \mathrm{~g}$ of $242(0.80 \mathrm{mmol}, 40 \%)$ as a yellow solid: IR 3057, 2929, $2244 \mathrm{~cm}^{-1} ;{ }^{1} \mathrm{H}$ NMR $\delta 7.65-7.52(10$ $\mathrm{H}, \mathrm{m}), 7.45-7.41(2 \mathrm{H}, \mathrm{m}), 7.38(2 \mathrm{H}, \mathrm{s}), 7.25(2 \mathrm{H}, \mathrm{td}, J=7.4$ and $1.0 \mathrm{~Hz}), 7.06(2 \mathrm{H}, \mathrm{t}, J=7.4$ Hz), $6.70(2 \mathrm{H}, \mathrm{d}, J=7.9 \mathrm{~Hz}), 4.40(2 \mathrm{H}, \mathrm{d}, J=21.8 \mathrm{~Hz}), 4.30(2 \mathrm{H}, \mathrm{d}, J=21.8 \mathrm{~Hz}), 3.93(2 \mathrm{H}$, d, $J=11.1 \mathrm{~Hz}), 3.38(2 \mathrm{H}, \mathrm{t}, J=9.4 \mathrm{~Hz}), 2.83-2.73(1 \mathrm{H}, \mathrm{m}), 2.06(3 \mathrm{H}, \mathrm{s}), 1.67-1.46(4 \mathrm{H}, \mathrm{m})$; ${ }^{13} \mathrm{C}$ NMR $\delta 144.1,143.5,141.9,139.3,138.6,136.0,135.5,132.2,130.1,130.0,129.0,128.9$, $127.7,126.9,126.6,126.5,124.7,123.7,123.5,68.7,59.1,44.4,35.7,29.9,18.8 ;$ HRMS calcd for $\mathrm{C}_{47} \mathrm{H}_{36} \mathrm{O}\left(\mathrm{MH}^{+}\right)$617.28389, found 617.27951.

Diiodide 241. To a flask containing $0.424 \mathrm{~g}$ of $242(0.688 \mathrm{mmol})$ in $50 \mathrm{~mL}$ of wet chloroform was added excess amount of iodotrimethylsilane. The flask of the reaction mixture was tightly closed and heated up to $70{ }^{\circ} \mathrm{C}$ for 3 days. After the reaction mixture was allowed to cool to 
room temperature, $20 \mathrm{~mL}$ of saturated sodium thiosulfate solution was introduced, and extracted with diethyl ether. The combined organic extracts were dried over sodium sulfate, and concentrated. The residue was purified by flash column chromatography (silica gel/10\% diethyl ether in hexanes, $R_{f}=0.77$ (hexanes:diethyl ether $\left.=6.5: 3.5\right)$ ) to furnish $0.447 \mathrm{~g}$ of 241 (0.523 mmol, 76\%): IR 3057, 2969, $2367 \mathrm{~cm}^{-1} ;{ }^{1} \mathrm{H}$ NMR $\delta 7.63-7.54(10 \mathrm{H}, \mathrm{m}), 7.43-7.42(2 \mathrm{H}$, m), $7.39(2 \mathrm{H}, \mathrm{s}), 7.25(2 \mathrm{H}, \mathrm{td}, J=7.4$ and $1.0 \mathrm{~Hz}), 7.06(2 \mathrm{H}, \mathrm{t}, J=7.2 \mathrm{~Hz}), 6.70(2 \mathrm{H}, \mathrm{d}, J=$ $8.4 \mathrm{~Hz}), 4.44(2 \mathrm{H}, \mathrm{d}, J=21.0 \mathrm{~Hz}), 4.32(2 \mathrm{H}, \mathrm{d}, J=21.6 \mathrm{~Hz}), 3.16-3.08(4 \mathrm{H}, \mathrm{m}), 2.94-2.90(1$ H, m), 2.30 (2 H, m), $2.02(3 \mathrm{H}, \mathrm{s}), 1.84-1.78(2 \mathrm{H}, \mathrm{m}) ;{ }^{13} \mathrm{C} \mathrm{NMR} \delta 144.1,143.5,141.8,139.5$, $138.4,135.6,135.5,132.5,130.1,130.0,129.0,129.0,127.8,127.1,126.6,126.6,124.8,123.8$, 123.5, 58.7, 46.6, 36.9, 35.8, 20.3, 6.55; HRMS calcd for $\mathrm{C}_{47} \mathrm{H}_{36} \mathrm{I}_{2}\left(\mathrm{MH}^{+}\right)$855.09791, found 855.09358 .

Polycyclic Aromatic Hydrocarbon 240 and 247. To a flask containing $0.161 \mathrm{~g}$ of $241(0.188$ $\mathrm{mmol})$ in THF $(50 \mathrm{~mL})$ was added $1.8 \mathrm{M}$ solution of LDA $(0.451 \mathrm{mmol})$ in THF $/ n$-heptane. The reaction mixture was stirred at room temperature for $8 \mathrm{~h}$, and quenched with water. The reaction mixture was extracted with diethyl ether, and dried over sodium sulfate, and concentrated. The residue was purified by flash column chromatography (silica gel $/ 5 \%$ diethyl ether in hexanes, $R_{f}=0.87$ (hexanes:diethyl ether $=8: 2$ )) to provide the polycyclic aromatic hydrocarbon 240 and $247(60.10 \mathrm{mg}, 0.0978 \mathrm{mmol})$ as an orange red solid in $8 \%$ and 44\%, respectively: IR 3062, 2923, $2023 \mathrm{~cm}^{-1} ; \mathbf{2 4 7 :}{ }^{1} \mathrm{H}$ NMR $\delta$ 7.58-7.46 $(10 \mathrm{H}, \mathrm{m}), 7.42-7.38(1 \mathrm{H}$, m), 7.264-7.23 (2 H, m), $7.19(1 \mathrm{H}, \mathrm{d}, J=8.4 \mathrm{~Hz}), 7.10(1 \mathrm{H}, \mathrm{t}, J=7.8 \mathrm{~Hz}), 7.04(1 \mathrm{H}, \mathrm{t}, J=7.8$ Hz), $7.02(1 \mathrm{H}, \mathrm{d}, J=9.0 \mathrm{~Hz}), 6.84(1 \mathrm{H}, \mathrm{s}), 6.78(1 \mathrm{H}, \mathrm{t}, J=7.2 \mathrm{~Hz}), 6.72(1 \mathrm{H}, \mathrm{d}, J=7.8 \mathrm{~Hz})$, 
$6.40(1 \mathrm{H}, \mathrm{d}, J=7.2 \mathrm{~Hz}), 4.12(1 \mathrm{H}, \mathrm{d}, J=12.0 \mathrm{~Hz}), 2.82-2.81(1 \mathrm{H}, \mathrm{m}), 2.69(1 \mathrm{H}, \mathrm{t}, J=13.2$ Hz), 2.46-2.44 (1 H, m), 2.39-2.36 (1 H, m), 2.22-2.17 (2 H, m), 1.71-1.66 (1 H, m), $1.68(3 \mathrm{H}$, s), 1.30-1.27 (2 H, m); ${ }^{13} \mathrm{C}$ NMR $\delta 151.3,148.6,147.5,145.6,143.2,141.7,140.4,139.4$, $139.1,138.2,137.1,136.1,134.8,134.3,130.5,130.4,129.9,129.5,128.9,128.8,128.1,127.6$, $127.5,127.2,127.0,126.9,125.3,124.8,124.3,123.8,123.6,123.2,121.9,120.2,64.4,61.2$, $50.7,47.9,46.8,29.3,28.6,27.2,20.0$.

Dimethoxy diketone 250. To a solution of the crude product of the dichloride (prepared from trans-diol $235(3.02 \mathrm{~g}, 4.51 \mathrm{~mol}))$ in $200 \mathrm{~mL}$ of THF was added $24 \mathrm{~mL}$ of $2 \mathrm{~N}$ sodium hydroxide aqueous solution at $0{ }^{\circ} \mathrm{C}$. The resulting mixture was stirred while a stream of air bubbled into the solution for $24 \mathrm{~h}$ at room temperature. The reaction mixture was concentrated in vacuum and then extracted with methylene chloride. The organic layer was washed with saturated $\mathrm{NH}_{4} \mathrm{Cl}$ and water, dried over sodium sulfate, and concentrated. The residue was purified by flash chromatography (silica gel $/ 30 \%$ diethyl ether in hexanes, $R_{f}=0.57$ (hexanes: diethyl ether $=6.5: 3.5))$ to afford $1.26 \mathrm{~g}$ of $\mathbf{2 5 0}(1.89 \mathrm{mmol}, 42 \%$ yield $)$ as a yellow solid. IR 3058, 2920, 2247, $1702 \mathrm{~cm}^{-1} ;{ }^{1} \mathrm{H}$ NMR $\delta 7.71(2 \mathrm{H}, \mathrm{d}, J=7.2 \mathrm{~Hz}), 7.63-7.56(6 \mathrm{H}, \mathrm{m}), 7.50(2$ $\mathrm{H}, \mathrm{d}, J=7.2), 7.42-7.41(2 \mathrm{H}, \mathrm{m}), 7.38(2 \mathrm{H}, \mathrm{s}), 7.21(2 \mathrm{H}, \mathrm{t}, J=7.2), 7.16(2 \mathrm{H}, \mathrm{t}, J=7.2), 6.42$ $(2 \mathrm{H}, \mathrm{d}, J=7.2 \mathrm{~Hz}), 3.70(2 \mathrm{H}, \mathrm{dd}, J=10.2$ and $4.8 \mathrm{~Hz}), 3.64-3.60(1 \mathrm{H}, \mathrm{m}), 3.40(2 \mathrm{H}, \mathrm{dd}, J=$ 10.2 and $6.6 \mathrm{~Hz}), 2.98(6 \mathrm{H}, \mathrm{s}), 2.40(3 \mathrm{H}, \mathrm{s}) ;{ }^{13} \mathrm{C}$ NMR $\delta 193.0,151.7,145.5,139.4,138.7$, $136.8,135.9,134.4,132.8,131.5,129.7,129.7,129.3,129.2,128.5,128.4,128.1,126.9,124.0$, 123.7, 71.4, 58.5, 58.3, 46.5, 18.5; HRMS calcd for $\mathrm{C}_{47} \mathrm{H}_{34} \mathrm{O}_{4}\left(\mathrm{MH}^{+}\right)$663.25299, found 663.25179 . 
Dibromoketone 252. The same procedure was repeated as described for $\mathbf{2 3 1}$ except that 0.645 $\mathrm{g}$ of $250(0.973 \mathrm{mmol})$ was used to afford $0.223 \mathrm{~g}$ of $\mathbf{2 5 2}(0.352 \mathrm{mmol}, 23 \%$ yield) as a yellow green solid $\left(R_{f}=0.59,(\right.$ hexanes:diethyl ether $\left.=6.5: 3.5)\right)$ : IR 2976, 2201, $1703 \mathrm{~cm}^{-1} ;{ }^{1} \mathrm{H} \mathrm{NMR}$ $\delta 7.72(2 \mathrm{H}, \mathrm{d}, J=7.2 \mathrm{~Hz}), 7.64-7.58(6 \mathrm{H}, \mathrm{m}), 7.53(2 \mathrm{H}, \mathrm{d}, J=6.6 \mathrm{~Hz}), 7.41-7.39(2 \mathrm{H}, \mathrm{m})$, $7.41(2 \mathrm{H}, \mathrm{s}), 7.23(2 \mathrm{H}, \mathrm{t}, J=7.2 \mathrm{~Hz}), 7.18(2 \mathrm{H}, \mathrm{t}, J=7.2 \mathrm{~Hz}), 6.43(2 \mathrm{H}, \mathrm{d}, J=7.2 \mathrm{~Hz}), 4.28$ $(2 \mathrm{H}, \mathrm{dd}, J=10.8$ and $3.6 \mathrm{~Hz}), 4.04-4.01(1 \mathrm{H}, \mathrm{m}), 3.48(2 \mathrm{H}, \mathrm{dd}, J=10.8$ and $6.6 \mathrm{~Hz}), 2.40(3$ $\mathrm{H}, \mathrm{s}) ;{ }^{13} \mathrm{C}$ NMR $\delta 193.1,149.1,145.4,139.7,138.6,136.4,135.5,134.8,133.7,132.0,129.8$, $129.5,129.4,129.3,128.7,128.6,128.6,127.4,124.2,123.8,59.8,48.6,34.7,19.0$; HRMS calcd for $\mathrm{C}_{45} \mathrm{H}_{28} \mathrm{Br}_{2} \mathrm{O}_{2}\left(\mathrm{MH}^{+}\right)$759.05288, found 759.05558.

Diketone 253. The same procedure was repeated as described for 250 except that the crude product of the dichloride 246 (prepared from trans-diol $(1.30 \mathrm{~g}, 2.00 \mathrm{mmol})$ ) in $100 \mathrm{~mL}$ of THF and $8 \mathrm{~mL}$ of $2 \mathrm{~N}$ sodium hydroxide aqueous solution was used to furnish $0.619 \mathrm{~g}$ of $\mathbf{2 5 3}(0.960$ mmol, $48 \%$ yield) as a yellow green solid $\left(\left(R_{f}=0.67\right.\right.$ (hexanes:diethyl ether $\left.\left.=4: 6\right)\right)$ : IR 2948, 2346, $1707 \mathrm{~cm}^{-1}$; ${ }^{1} \mathrm{H}$ NMR $\delta 7.71(2 \mathrm{H}, \mathrm{dd}, 7.9$ and $1.2 \mathrm{~Hz}), 7.64-7.48(8 \mathrm{H}, \mathrm{m}), 7.43-7.40(2 \mathrm{H}$, m), $7.38(2 \mathrm{H}, \mathrm{s}), 7.22(2 \mathrm{H}, \mathrm{dd}, \mathrm{J}=6.9$ and $1.0 \mathrm{~Hz}), 7.17(2 \mathrm{H}, \mathrm{td}, J=7.4$ and $1.5 \mathrm{~Hz}), 6.41(2$ $\mathrm{H}, \mathrm{d}, J=6.9 \mathrm{~Hz}), 3.85(2 \mathrm{H}, \mathrm{dd}, J=11.4$ and $3.7 \mathrm{~Hz}), 3.35(2 \mathrm{H}, \mathrm{t}, J=10.9 \mathrm{~Hz}), 3.23-3.14(1 \mathrm{H}$, m), $2.45(3 \mathrm{H}, \mathrm{s}), 1.61(2 \mathrm{H}, \mathrm{t}, J=11.4 \mathrm{~Hz}), 1.37-1.22(2 \mathrm{H}, \mathrm{m}) ;{ }^{13} \mathrm{C}$ NMR $\delta 193.1,150.9,145.3$, $139.7,138.9,136.6,135.8,134.6,133.0,131.5,129.7,129.6,129.3,129.3,128.6,128.5,127.2$, 124.0, 123.7, 68.5, 61.6, 44.1, 29.9, 17.1; HRMS calcd for $\mathrm{C}_{47} \mathrm{H}_{32} \mathrm{O}_{3}\left(\mathrm{MH}^{+}\right)$645.24242, found 645.24283. 
Diiododiketone 254. The same procedure was repeated as described for 252 except that 0.201 $\mathrm{g}$ of 253 (3.12 $\mathrm{mmol})$ was reacted for 10 days to afford $1.87 \mathrm{~g}$ of $254(2.12 \mathrm{mmol}, 68 \%)$ as a yellow solid $\left(R_{f}=0.63\right.$, (hexanes:diethyl ether $\left.\left.=6.5: 3.5\right)\right):$ IR $3061,2927,2355,1705 \mathrm{~cm}^{-1} ;{ }^{1} \mathrm{H}$ NMR $\delta 7.75(2 \mathrm{H}, \mathrm{d}, \mathrm{J}=6.6 \mathrm{~Hz})$, 7.66-7.51 (8 H, m), 7.41-7.38 (2 H, m), $7.40(2 \mathrm{H}, \mathrm{s}), 7.23(2$ $\mathrm{H}, \mathrm{td}, J=7.8$ and $1.2 \mathrm{~Hz}), 7.17(2 \mathrm{H}, \mathrm{td}, J=7.8$ and $1.2 \mathrm{~Hz}), 6.42(2 \mathrm{H}, \mathrm{d}, J=7.2 \mathrm{~Hz}), 3.25-3.12$ (5 H, m), 2.43-2.37 (2 H, m), 2.35 (3 H, s), 1.70-1.57 (2 H, m); ${ }^{13} \mathrm{C}$ NMR $\delta$ 192.8, 150.5, 145.3, $139.8,138.5,136.5,135.7,134.6,133.3,131.8,129.7,129.6,129.3,129.3,128.7,128.5,128.5$, 127.3, 124.2, 123.8, 61.1, 47.9, 36.5, 18.4, 6.0; HRMS calcd for $\mathrm{C}_{47} \mathrm{H}_{32} \mathrm{I}_{2} \mathrm{O}_{2}\left(\mathrm{MH}^{+}\right)$883.05644, found 883.05545 .

2-(Indan-2-yl)-1,3-indandione 259. The same procedure was repeated as described for 234 except that $1.32 \mathrm{~g}$ of 2 -indanone (10.0 mmol), $1.46 \mathrm{~g}$ of 1,3-indandione $(10.0 \mathrm{mmol}), 2.53 \mathrm{~g}$ of Hantzsch ester $(10.0 \mathrm{mmol})$, and $0.23 \mathrm{~g}$ of L-proline $(3.00 \mathrm{mmol})$ were used to furnish 259 . Pale black solid product was obtained by column chromatography $2.10 \mathrm{~g}$ of $259(8.00 \mathrm{mmol}$, $80 \%$ yield) (silica gel $/ 20 \%$ diethyl ether in hexanes, $R_{f}=0.42$, (hexanes:diethyl ether $\left.=7: 3\right)$ ): IR $2980,2357,1705 \mathrm{~cm}^{-1} ;{ }^{1} \mathrm{H}$ NMR $\delta$ 8.01-7.84 (m, $4 \mathrm{H}$, indanyl aromatic H), 7.20-7.11 (4 $\mathrm{H}, \mathrm{m}), 3.22-2.99(6 \mathrm{H}, \mathrm{m}) ;{ }^{13} \mathrm{C} \mathrm{NMR} \delta 200.4,142.5,142.2,135.7,126.4,124.3,123.2,55.5$, $39.6,36.4$.

2-Methyl-2-(indan-2-yl)-1,3-indandione 260. The same procedure was repeated as described for 234 except that $0.989 \mathrm{~g}$ of $259(3.77 \mathrm{mmol})$ in $30 \mathrm{~mL}$ of $\mathrm{THF}$ and $5.00 \mathrm{~mL}$ of a $1.0 \mathrm{M}$ solution of potassium $t$-butoxide $(5.00 \mathrm{mmol})$ in 2-methyl-2-propanol, and $2.00 \mathrm{~g}$ of iodomethane (13.8 $\mathrm{mmol})$ were used to furnish $\mathbf{2 6 0}$. The residue was purified by flash column 
chromatography (silica gel $/ 15 \%$ diethyl ether in hexanes, $R_{f}=0.49$ (hexanes:diethyl ether $=$ 7:3)) to give $0.817 \mathrm{~g}$ of $\mathbf{2 6 0}$ (2.98 mmol, 79\% yield): IR 3061, 2353, $1740 \mathrm{~cm}^{-1} ;{ }^{1} \mathrm{H}$ NMR $\delta$ 8.01-7.83 (m, $4 \mathrm{H}$, indanyl aromatic $\mathrm{H}), 7.13-7.06(4 \mathrm{H}, \mathrm{m}), 3.02-2.79(5 \mathrm{H}, \mathrm{m}), 1.42(3 \mathrm{H}, \mathrm{s})$; ${ }^{13} \mathrm{C}$ NMR $\delta$ 204.2, 142.0, 141.2, 135.8, 126.3, 124.2, 123.3, 54.5, 45.4, 34.2, 17.5; HRMS calcd for $\mathrm{C}_{19} \mathrm{H}_{16} \mathrm{O}_{2}\left(\mathrm{MH}^{+}\right)$277.12231, found 277.12224.

Propargylic diols 261. The same procedure was repeated as described for $\mathbf{2 3 5}$ except that 3.04 $\mathrm{g}$ of 1-(2-ethynylphenyl)-2-phenylethyne (15.2 mmol) in $50 \mathrm{~mL}$ of THF, $9.48 \mathrm{~mL}$ of $1.6 \mathrm{M}$ solution of $n$-butyl lithium, and a solution of $1.37 \mathrm{~g}$ of $\mathbf{2 6 0}(4.98 \mathrm{mmol})$ in $20 \mathrm{~mL}$ of THF were used to furnish 261. The residue was purified by flash column chromatography (silica gel/70\% diethyl ether in hexanes, $R_{f}=0.32$ (hexanes:diethyl ether $\left.=4: 6\right)$ ) to give $2.72 \mathrm{~g}$ of $\mathbf{2 6 1}(4.08$ mmol, 82\% yield): IR $3535,3063,2935,2344 \mathrm{~cm}^{-1} ;{ }^{1} \mathrm{H}$ NMR $\delta 7.74(1 \mathrm{H}, \mathrm{d}, J=7.4 \mathrm{~Hz})$, 7.61-7.45 (6 H, m), 7.38-7.28 (14 H, m), 7.23-7.06 (5 H, m), 3.98-3.84 (1 H, m), 3.40-3.07 (5 H, m), $2.60(2 \mathrm{H}, \mathrm{s}), 1.21(3 \mathrm{H}, \mathrm{s}) ;{ }^{13} \mathrm{C}$ NMR $\delta 144.3,143.4,143.3,143.1,132.2,132.0,131.8$, 131.7, 130.1, 129.4, 128.5, 128.3, 128.2, 128.0, 127.9, 125.9, 125.8, 125.6, 125.0, 124.9, 125.0, $124.9,124.5,124.2,124.1,123.6,122.9,122.7,94.5,93.4,93.2,93.0,88.1,87.6,85.8,81.0$, 80.0, 61.3, 59.6, 51.9, 41.8, 34.7, 34.6.

Indanyldiketone 262. The same procedure was repeated as described for $\mathbf{2 5 0}$ except that the crude product of the dichloride $\mathbf{2 6 1}$ in $100 \mathrm{~mL}$ of THF and $8 \mathrm{~mL}$ of $2 \mathrm{~N}$ sodium hydroxide aqueous solution was used to furnish $0.379 \mathrm{~g}$ of $\mathbf{2 6 2}(0.560 \mathrm{mmol}, 28 \%$ yield $)$ as a yellow solid $\left(R_{f}=0.65\right.$ (hexanes:diethyl ether $\left.\left.=7: 3\right)\right)$; IR 3061, 2236, $1716 \mathrm{~cm}^{-1} ;{ }^{1} \mathrm{H}$ NMR $\delta 7.69(2 \mathrm{H}, \mathrm{d}, J$ $=7.2 \mathrm{~Hz}), 7.63-7.58(6 \mathrm{H}, \mathrm{m}), 7.50(2 \mathrm{H}, \mathrm{d}, J=7.2 \mathrm{~Hz}), 7.41(2 \mathrm{H}, \mathrm{s}), 7.41(2 \mathrm{H}, \mathrm{m}), 7.21-7.13$ 
(4 H, indanyl aromatic H) , 6.98-6.93 (4 H, m), $6.39(2 \mathrm{H}, \mathrm{d}, J=7.8 \mathrm{~Hz}), 4.17-4.11(1 \mathrm{H}, \mathrm{m})$, $2.88(2 \mathrm{H}, \mathrm{dd}, J=15.0$ and $7.2 \mathrm{~Hz}), 3.40(2 \mathrm{H}, \mathrm{dd}, J=15.6$ and $11.4 \mathrm{~Hz}), 2.60(3 \mathrm{H}, \mathrm{s}) ;{ }^{13} \mathrm{C}$ NMR $\delta 193.1,150.9,145.3,143.2,139.7,138.6,136.7,135.8,134.5,133.0,131.7,129.7$, $129.6,129.3,129.3,128.6,128.5,127.2,125.8,124.0,123.7,60.6,49.2,35.8,18.7$; HRMS calcd for $\mathrm{C}_{51} \mathrm{H}_{32} \mathrm{O}_{2}\left(\mathrm{MH}^{+}\right)$677.24751, found 677.24696. 


\section{References}

1. Lee, M. D.; Ellestad, G. A.; Borders, D. B. Acc. Chem. Res. 1991, 24, 235-243.

2. (a) Thorson, J. S.; Shen, B.; Whitwam, R. E.; Liu, W.; Li, Y.; Ahlert, J. Bioorg. Chem. 1999, 27, 172. (b) Xi, Z.; Goldberg, I. H. Comprehensive Natural Products Chemistry; Elsevier: New York, 1999; Chapter 7, p 533.

3. Galm, U.; Hager, M. H.; Vanlanen, S. G.; Ju, J.; Thorson, J. S.; Shen, B. Chem. Rev. 2005, 105, 739-758.

4. Edo, K.; Mizugaki, M.; Koide, Y.; Seto, H.; Furihata, K.; Otake, N.; Ishida, N. Tetrahedron Lett. 1985, 26, 331-334.

5. (a) Edo, K.; Saito, K.; Matsuda, Y.; Akiyamamurai, Y.; Mizugaki, M.; Koide, Y.; Ishida, N. Chem. Pharm. Bull. 1991, 39, 170-176. (b) Myers, A. G.; Proteau, P. J.; Handel, T. M. J. Am. Chem. Soc.1988, 110, 7212-7214. (c) Koide, Y.; Ishii, F.; Hasuda, K.; Koyama, Y.; Edo, K.; Katamine, S.; Kitame, F.; Ishida, N. J. Antibiot. 1980, 33, 342-346.

6. Kawata, S.; Ashizawa, S.; Hirama, M. J. Am. Chem. Soc. 1997, 119, 12012-12013.

7. Leet, J. E.; Schroeder, D. R.; Hofstead, S. J.; Golik, J.; Colson, K. L.; Huang, S.; Klohr, S. E.; Doyle, T. W.; Matson, J. A. J. Am. Chem. Soc. 1992, 114, 7946-7948.

8. Otani, T.; Minami, Y.; Sakawa, K.; Yoshida, K. J. Antibiot. 1991, 44, 564-568.

9. Schroeder, D. R.; Colson, K. L.; Klohr, S. E.; Zein, N.; Langley, D. R.; Lee, M. S.; Matson, J. A.; Doyle, T. W. J. Am. Chem. Soc.1994, 116, 9351-9352.

10. (a) Ando, T.; Ishii, M.; Kajiura, T.; Kameyama, T.; Miwa, K.; Sugiura, Y. Tetrahedron Lett. 1998, 39, 6495-6498. (b) Kobayashi, S.; Reddy, R. S.; Sugiura, Y.; Sasaki, D.; Miyagawa, N.; Hirama, M. J. Am. Chem. Soc. 2001, 123, 2887-2888. (c) Kobayashi, S.; Ashizawa, S.; Takahashi, Y.; Sugiura, Y.; Nagaoka, M.; Lear, M. J.; Hirama, M J. Am. Chem. Soc. 2001, 123, 1129411295.

11. (a) Khokhlov, A. S.; Cherches, B. Z.; Reshetov, P. D.; Smirnova, G. M.; 
Sorokina, I. B. J. Antibiot. 1969, 22, 541-545. (b) Khokhlov, A. S.; Reshetov, P. D.; Chupova, L. A.; Cherches, B. Z.; Zhigis, L. S.; Stoyachenko, I. A. J. Antibiot. 1976, 29, 1026-1034.

12. Yamaguch, T.; Furumai, T.; Sato, M.; Okuda, T.; Ishida, N. J. Antibiot. 1970, $23,369-372$.

13. (a) Chimura, H.; Ishizuka, M.; Hamada, M.; Hori, S.; Kimura, K. J. Antibiot. 1968, 21, 44-49. (b) Hidaka, T.; Yano, Y.; Yamashita, T.; Watanabe, K. J. Antibiot. 1979, 32, 340-346. (c) Yamashita, T.; Naoi, N.; Watanabe, K.; Takeuchi, T.; Umezawa, H. J. Antibiot. 1976, 29, 415-423.

14. (a)Komiyama, K.; Umezawa, I. J. Antibiot. 1978, 31, 473-476. (b) Okamoto, M.; Komiyama, K.; Takeshima, H.; Yamamoto, H. (c) Umezawa, I. J. Antibiot. 1979, 32, 386-396.

15. Zhen, Y.; Ming, X.; Yu, B.; Otani, T.; Saito, H.; Yamada, Y. J. Antibiot. 1989, 42, 1294-1298.

16. (a) Darby, N.; Kim, C. U.; Salaün, J. A.; Shelton, K. W.; Takada, S.; Masamune, S. J. Chem. Soc., Chem. Commun. 1971, 1516-1517. (b) Lockhart, T. P.; Bergman, R. G. J. Am. Chem. Soc. 1981, 103, 4091-4096.

17. Nicolaou, K. C.; Zuccarello, G.; Riemer, C.; Estevez, V. A.; Dai, W.-M. J. Am. Chem. Soc. 1992, 114, 7360-7371.

18. Smith, A. L.; Nicolaou, K. C. J. Med. Chem. 1996, 39, 2103-2117.

19. Dai, W. M. Curr. Med. Chem. 2003, 10, 2265-2283.

20. Banfi, L.; Basso, A.; Guanti, G.; Riva, R. Arkivoc 2006, 7, 261-275.

21. Trail, P. A.; King, H. D.; Dubowchik, G. M. Cancer Immunol.Immunother. 2003, 52, 328-337.

22. Myers, A. G.; Cohen S. B.; Kwon, B. J. Am. Chem. Soc. 1994, 116, 1255-1271.

23. Schmittel, M.; Keller, M.; Kiau, S.; Strittmatter, M. Chem. Eur. J. 1997, 3, 807816.

24. Yang, Y. H. Ph.D. Thesis, West Virginia University 2004. 
25. Mayer, J.; Sondheimer, F. J.Am.Chem.Soc. 1966, 88, 603-604.

26. Derby, N.; Kim, C. U.; Salaun, J. A.; Shelton, K. W.; Takada, S.; Masamune, S. Chem. Commun. 1971, 1516-1517.

27. Grissom, J. W.; Gunawardena, G. U.; Klingberg, D.; Huang, D. Tetrahedron 1996, 19, 6453-6518.

28. Musch, P. W.; Remenyi, C.; Helten, H.; Engels, B. J. Am. Chem. Soc. 2002, $124,1823-1828$.

29. (a) Wang, K. K. Chem. Rev. 1996, 96, 207-222. (b) Moore, H. W.; Yerxa, M.

R. Chemtracts 1992, 273-276. (c) Sullivan, R. W.; Coghlan, V. M.; Munk, S. A.; Reed, M. W.; Moore, H. W. J. Org. Chem. 1994, 59, 2276-2278. (d)

Padwa, A.; Austin, D. J.; Chiacchio, U.; Kassir, J. M.; Rescifina, A.; Xu, S. L. Tetrahedron Lett. 1991, 32, 5923-5924. (e) Foland, L. D.; Karlsson, J. O.; Perri, S. T.; Schwabe R.; Xu, S. L., Patil, S.; Moore, H. W. J. Am. Chem. Soc. 1989, $111,975-989$.

30. (a) Jones, R. R.; Bergman, R. G. J. Am. Chem. Soc. 1972, 94, 660-661. (b) Lockhart, T. P.; Comita, P. B.; Bergman, R. G. J. Am. Chem. Soc. 1981, 103, $4082-4890$.

31. Edo, K.; Koide, Y. Neocarzinostatin: The Past, the Present and Future of an Anticancer Drug; Maeda, H., Edo, K., Ishida, N., Eds.; Springer: Tokyo; 1997; pp 23-45.

32. (a) Myers, A. G.; Kuo, E. Y.; Finney, N. S. J. Am. Chem. Soc. 1989, 111, 8057-8059. (b) Nagata, R.; Yamanaka, H.; Okazaki, E.; Saito, I. Tetrahedron Lett. 1989, 30, 4995-4998.

33. (a) Schmittel, M.; Strittmatter, M.; Kiau, S. Tetrahedron Lett. 1995, 36, 49754978. (b) Schmittel, M.; Kiau, S. Liebigs Ann. 1997, 733-736. (c) Schmittel, M.; Keller, M.; Kiau, S.; Strittmatter, M. Chem. Eur. J. 1997, 3, 807-816. (d) Schmittel, M.; Strittmatter, M.; Kiau, S. Angew. Chem., Int. Ed. Engl. 1996, 35, $1843-1845$ 
34. Foland, L. D.; Karlsson, J. O.; Perri, S. T.; Schwabe, R.; Xu, S. L.; Moore, H. W. J. Am. Chem. Soc. 1989, 111, 975-989.

35. (a) Nagata, R.; Yamanaka, H.; Murahashi, E.; Saito, I. Tetrahedron Lett. 1990, 31, 2907-2910. (b) Nagata, R.; Yamanaka, H.; Okazaki, E.; Saito, I. Tetrahedron 1989, 30, 4995-4998.

36. Myers, A. G.; Kuo, E. Y.; Finney, N. S. J. Am. Chem. Soc. 1989, 111, 80578059.

37. Koga, N.; Morokuma, K. J. Am. Chem. Soc. 1991, 113, 1907-1911.

38. (a) Schmittel, M.; Strittmatter, M.; Kiau, S. Tetrahedron Lett. 1995, 36, 49754978; (b) Schmittel, M.; Strittmatter, M.; Vollmann, K.; Kiau, S. Tetrahedron Lett. 1996, 37, 999-1002; (c) Schmittel, M.;Strittmatter, M.; Kiau, S. Angew. Chem. 1996, 108, 1952-1954. (d) Schmittel, M.; Keller, M.; Kiau, S.; Strittmatter, M. Chem. Eur. J. 1997, 3, 807-816; (e) Engels, B.; Lennartz, C.; Hanrath, M.; Schmittel, M.; Strittmatter, M. Angew. Chem. 1998, 110, 20672070; Angew. Chem. Int. Ed. 1998, 37, 1060-1063.

39. Gillmann, T.; Hulsen, T.; Massa, W.; Wocadlo, S. Synlett 1995, 1257-1259.

40. Garcia, J. G.; Ramos, B.; Pratt, L. M.; Rodrfguez A. Tetrahedron Lett. 1995, 36, 7391-7394.

41. Schmittel, M.; Strittmatter, M.; Mahajan, A. A.; Vavilala, C.; Emin Cinar, M.; Maywalda, M. Arkivoc. 2007, 8, 66-84.

42. Schmittel, M.; Steffen, J.; Auer, D.; Maywald, M. Tetrahedron Lett. 1997, 38, $6177-6180$.

43. Liu, B.; Wang, K. K.; Petersen J. L. J. Org. Chem. 1996, 61, 8503 -8507.

44. Brunette, S. R.; Lipton, M. A. J. Org. Chem. 2000, 65, 5114-5119.

45. (a) Evans, D. A.; Golob, A. M. J. Am. Chem. Soc. 1975, 97, 4765-4766. (b)

Steigerwald, M. L.; Goddard, W. A., III; Evans, D. A. J. Am. Chem. Soc. 1979, 101, 1994-1997.

46. (a) Shi, C.; Wang, K. K. J. Org. Chem. 1998, 63, 3517-3520. (b) Shi, C.; 
Zhang, Q.; Wang, K. K. J. Org. Chem. 1999, 64, 925-932. (c) Schmittel, M.; Steffen, J. P.; Wencesla-Angel, M. A.; Engels, B.; Lennartz, C.; Hanrath, M. Angew. Chem. Int. Ed.Engl. 1998, 37, 1562-1564. (d) Schmittel, M.; Steffen, J. P.; Engels, B.; Lennartz, C.; Hanrath, M. Angew. Chem. Int. Ed. Engl. 1998, 37, 2371-2373.

47. (a) Li, H.; Yang, H.; Petersen, J. L. Wang, K. K. J. Org. Chem. 2004, 69, 45004508. (b) Zhang, Q.; Shi, C.; Zhang, H.-R.; Wang, K. K. J. Org. Chem. 2000, 65, 7977-7983. (c) Li, H.; Petersen, J. L.; Wang, K. K. J. Org. Chem. 2001, 66, 7804-7810.

48. Lu, X.; Petersen, J. L.; Wang, K. K. J. Org. Chem. 2002, 67, 7797-7801.

49. Lu, X.; Petersen, J. L.; Wang, K. K. Org. Lett. 2003, 5, 3277-3280.

50. Dai, W.; Petersen, J. L.; Wang, K. K. Org. Lett. 2006, 8, 4665-4667.

51. (a) Schmittel, M.; Strittmatter, M.; Kiau, S. Angew. Chem., Int.Ed. Engl. 1996, 35, 1843-1845. (b) Schmittel, M.; Strittmatter, M.;Vollmann, K.; Kiau, S. Tetrahedron Lett. 1996, 37, 999-1002. (c) Schmittel, M.; Steffen, J. P.; Auer, D.; Maywald, M. Tetrahedron Lett. 1997, 38, 6177-6180. (d) Schmittel, M.; Keller, M.; Kiau, S.; Strittmatter, M. Chem. Eur. J. 1997, 3, 807-816. (e) Engels, B.; Lennartz, C.; Hanrath, M.; Schmittel, M.; Strittmatter, M. Angew. Chem., Int.Ed. 1998, 37, 1960-1963. (f) Schmittel, M.; Strittmatter, M. Tetrahedron 1998, 54, 13751-13760. (g) Li, H. B.; Zhang, H. R.; Petersen, J. L.; Wang, K. K. J. Org. Chem. 2001, 66, 6662-6668. (h) Schmittel, M.; Steffen, J. P.; Maywald, M.; Engels, B.; Helten, H.; Musch, P. J.Chem. Soc., Perkin Trans. 2 2001, 1331-1339. (i) Yang, Y. H.; Petersen, J. L.; Wang, K. K. J. Org. Chem. 2003, 68, 5832-5837. (j) Yang, Y. H.; Petersen, J. L.; Wang, K. K. J. Org. Chem. 2003, 68, 8545-8549.

52. Engels, B.; Lennartz, C.; Hanrath, M.; Schmittel, M.; Strittmatter, M. Angew. Chem. Int. Ed. Engl. 1998, 37, 1960-1963.

53. Schmittel, M.; Strittmatter, M.; Kiau, S. Angew. Chem. 1996, 108, 1952-1954; 
Angew. Chem. Int. Ed. Engl. 1996, 35, 1843-1845.

54. (a) Wiberg, K. B. Chem. Rev. 1955, 55, 713-743. (b) Collins, C.J., Brown, N. S., Eds. Isotope Effects in Chemical Reactions; von Nostrand Reinhold: New York, 1970. (c) Bell, R. P. The Proton inChemistry, 2nd ed.; Cornell University Press: Ithaca, NY, 1974. (d) Stephenson, L. M.; Grdina, M. J.; Orfanopoulos, M. Acc. Chem. Res.1980, 13, 419-425. (e) Melander, L.; Saunders, W. H., Jr. ReactionRates of Isotopic Molecules; Wiley-Interscience: New York, 1980. (f) Singleton, D. A.; Hang, C.; Szymanski, M. J.; Greenwald, E. E. J. Am.Chem. Soc. 2003, 125, 1176-1177.

55. Schmittel, M.; Vavilala, C. J. Org. Chem. 2005, 70, 4865-4868.

56. (a) Nagata, R.; Yamanaka, H.; Okazaki, E.; Saito, I. Tetrahedron Lett. 1989, 30, 4995-4998. (b) Nagata, R.; Yamanaka, H.; Murahashi, E.; Saito, I.

Tetrahedron Lett. 1990, 31, 2907-2910.

57. Nicolaou, K. C.; Maligres, P.; Shin, J.; de Leon, E.; Rideout, D. J. Am. Chem. Soc. 1990, 112, 7825-7826.

58. (a) Grissom, J. W.; Huang, D. J. Org. Chem. 1994, 59, 5114-5116. (b) Grissom, J. W.; Klingberg, D.; Huang, D.; Slattery, B. J. Org. Chem. 1997, 62, 603- 606. (c) Yang, Y.; Diederich, F.; Valentine, S. J. J. Am. Chem. Soc. 1990, 112, 7826 $-7828$.

59. (a) Schmittel, M.; Strittmatter, M.; Vollmann, K.; Kiau, S. Tetrahedron Lett. 1996, 37, 999-1002. (b) Schmittel, M.; Strittmatter, M.; Kiau, S. Angew. Chem. Int. Ed. Engl. 1996, 35, 1843-1845. (c) Schmittel, M.; Kiau, S.; Siebert, T.; Strittmatter, M. Tetrahedron Lett. 1996, 37, 7691-7694.

60. Fujiwara, K.; Sakai, H.; Hirama, M. J. Org. Chem. 1991, 56, 1688-1689.

61. Gillmann, T.; Hülsen, Y.; Massa, W.; Wocadlo, S. Synlett 1995, 1257-1259.

62. Wu, M.-J.; Lin, C.-F.; Wu, J.-S.; Chen, H.-T. Tetrahedron Lett. 1994, 35, $1879-1882$.

63. Dopico, P. G.; Finn, M. G. Tetrahedron 1999, 55, $29-62$. 
64. Zhao, J.; Hughes, C. O.; Toste, F. D. J. Am. Chem. Soc. 2006, 128, 7436.

65. (a) Sygula, A.; Karlen, S. D.; Sygula, R.; Rabideau, P. W. Org. Lett. 2002, 4, 3135-3137. (b) Mehta, G.; Rao, H. S. P. Tetrahedron 1998, 54, 13325-13370.

66. (a) Barth, W. E. Ph.D. Thesis, University of Michigan, Ann Arbor,MI, 1966. (b) Barth, W. E.; Lawton, R. G. J. Am. Chem. Soc. 1966, 88, 380-381. (c) Barth, W. E.; Lawton, R. G. J. Am. Chem. Soc. 1971, 93, 1730-1745.

67. Seiders, T. J.; Baldridge, K. K.; Siegel, J. S. J. Am. Chem. Soc. 1996, 118, 27542755 .

68. Pyrolytic methods in organic chemistry: application of flow and flash vacuum pyroltyic techniques / Roger F. C. Brown. New York : Academic Press, 1980.

69. (a) Brown, R. F. C.; Harrington, K. J.; McMullen, G. L. J. Chem. Soc. Chem. Commun. 1974, 123-124. (b) Brown, R. F. C.; Eastwood, F. W.; Jackman, G. P. Ausf. J. Chem. 1977, 30, 1757-1767. (c) Brown R. F. C.; Eastwood, F. W.; Jackman, G. P. Ausl. J . Chem. 1978, 31, 579-586. (d) Brown, R. F. C.; Eastwood, F. W.; Harrington, K. J.; McMullen, G. L. Aust. J. Chem. 1974, 27, $2393-2402$.

70. Scott, L. T.; Hashemi, M. M.; Meyer, D. T.; Warren, H. B. J. Am. Chem. Soc. 1991, 113, 7082-7084

71. (a) Abdourazak, A. H.; Sygula, A.; Rabideau, P. W. J. Am. Chem. Soc.1993, 115, 3010-3011. (b) Sygula, A.; Abdourazak, A. H.; Rabideau, P. W. J. Am. Chem. Soc.1996, 118, 339-343.

72. (a) Scott, L. T. Pure Appl. Chem. 1996, 68, 291-300. (b) Bronstein, H. E.; Choi, N.; Scott, L. T. J. Am. Chem. Soc. 2002,124, 8870-8875.

73. (a) Rabideau, P. W.; Abdourazak, A. H.; Folsom, H. E.; Marcinow, Z.;Sygula, A.; Sygula, R. J. Am. Chem. Soc. 1994, 116, 7891-7892. (b) Clayton, M. D.; Marcinow, Z.; Rabideau, P. W. J. Org. Chem. 1996, 61, 6052-6054.

74. Abdourazak, A. H.; Marcinow, Z.; Sygula, A.; Sygula, R.; Rabideau, P. W. J. Am. Chem. Soc. 1995, 117, 6410-6411. 
75. (a) Scott, L. T.; Boorum, M. M.; McMahon, B. J.; Hagen, S.; Mack, J.; Blank, J.; Wegner, H.; de Meijere, A. Science 2002, 295, 1500-1503. (b) Reisch, H. A.; Bratcher, M. S.; Scott, L. T. Org. Lett. 2000, 2, 1427-1430.

76. (a) Sygula, A.; Xu, G.; Marcinow, Z.; Rabideau, P. W. Tetrahedron, 2001, 57, 3637-3644. (b) Sastry, G. N. Current Science 2003, 85. 125-126.

77. Sygula, A.; Rabideau, W. J. Am. Chem. Soc. 1999, 121, 7800-7803.

78. Sygula, A.; Rabideau, P. W. J. Amer. Chem. Soc. 2000, 122, 6323-6324.

79. Herrmann, W. A.; Brossmer, C.; Oefele, K.; Reisinger, C.-P.; Priermeier, T.; Beller, M.; Fischer, H. Angew. Chem., Int. Ed. Engl. 1995, 34, 1844-7.

80. (a) Diederich, F.; Rubin, Y. Angew. Chem., Int. Ed. Engl. 1992, 31, 1101-1123.

(b) McElvany, S. W.; Ross, M. M.; Goroff, N. S.; Diederich, F. Science 1993, 259, 1594-1596. (c) Sastry, G. N.; Jemmis, E. D.; Mehta, G.; Shah, S. R. J. Chem. Soc., Perkin Trans. 2 1993, 1867-1871.

81. Bradshaw, J. D.; Guo, L.; Tessier, C. A.; Youngs, W. J. Organometallics 1996, $15,2582-2584$.

82. Grilli, S.; Lunazzi, L.; Mazzanti, A.; Pinamonti, M. Tetrahedron 2004, 60, $4451-4458$.

83. Rice, J. E.; Cai, Z.-W. J. Org. Chem. 1993, 58, 1415-1424.

84. (a) Haddon, R. C.; Scott, L. T. Pure Appl. Chem. 1986, 58, 137-142. (b) Haddon, R. C. J. Am. Chem. Soc. 1987, 109, 1676-1685. (c)Haddon, R. C. Science 1993, 261, 1545-1550. (d) Jackson, E. A.; Steinberg, B. D.; Bancu, M.; Wakamiya, A.; Scott, L. T., J. Am. Chem. Soc., 2007, 129, 484-485.

85. Bronstein, H. E.; Choi, N.; Scott, L. T. J. Am. Chem. Soc. 2002, 124, 88708875 .

86 (a) Seiders, T. J.; Baldridge, K. K.; Siegel, J. S. J. Am. Chem. Soc. 1996, 118 , 2754-2755. (b) Scott, L. T.; Hashemi, M. M.; Bratcher, M. S. J. Am. Chem.Soc. 1992, 114, 1920-1921. (c) Sygula, A.; Rabideau, P. W. Theochem 1995, 333, 215-226. (d) Biedermann, P. U.; Pogodin, S.; Agranat, I. J. Org. Chem. 1999, 
64, 3655-3662. (e) Marcinow, Z.; Sygula, A.; Ellern, A.; Rabideau, P. W. Org. Lett. 2001, 3, 3527-3529. (f) Seiders, T. J.; Baldridge, K. K.; Grube, G. H.; Siegel, J. S. J. Am. Chem. Soc. 2001, 123, 517-525.

87. Abdourazak, A. H.; Sygula, A.; Rabideau, P. W. J. Am. Chem. Soc. 1993, 115, $3010-3011$

88. Ojima, I., Ed. Catalytic Asymmetric Synthesis, 2nd ed.; Wiley-VCH: New York, 2000.

89. Cervinka, O., Enantioselective Reactions in Organic Chemistry, 1st ed.; Prentice Hall, 1996.

90. Jacques, J., Collet, A. \& Wilen, S. H. (1981) Enantiomers, Racemates and Resolution.

91. Pummerer, R.; Prell, E.; Rieche, A. Chem. Ber. 1926, 59, 2159-2163.

92. (a) Noyori, R.; Tomino, I.; Tanimoto, Y. J. Am. Chem. Soc. 1979, 101, 31293131. (b) Noyori, R.; Tomino, I.; Tanimoto, Y. J. Am. Chem. Soc. 1979, 101, 5843-5844. (c) Nishizawa, M.; Noyori. R. Tetrahedron Lett. 1980, 36, 2821 2822. (d) Noyori, R. Chem. Soc. Rev. 1989, 18, 187-208.

93. (a) Miyashita, A.; Yasuda, A.; Takaya, H.; Toriumi, K.; Ito, T.; Souchi, T.; Noyori, R. J. Am. Chem. Soc. 1980, 102, 7932-7934. (b) Miyashita, A.; Takaya, H.; Souchi, T.; Noyori, R. Tetrahedron 1984, 40, 1245-1253. (c) Takaya, H.; Mashima, K.; Koyano, K.; Yagi, M.; Kumobayashi, H.; Taketomi, T.; Akutagawa, S.; Noyori, R. J. Org. Chem. 1986, 51, 629-631. (d) Takaya, H.; Akutagawa, S.; Noyori, R. Org. Synth. 1988, 67, 20-32. (e) Noyori, R.; Takaya, H. Acc. Chem. Res. 1990, 23, 345-350. (f) Takaya, H.; Ohta, T.; Mashima, K.; Noyori, R. Pure Appl. Chem. 1990, 62, 1135-1138. (g) Noyori, R.; Koizumi, M.; Ishii, D.; Ohkuma, T. Pure Appl. Chem. 2002, 73, 227-232. (h) Noyori, R. Angew. Chem., Int. Ed. 2002, 41, 2008-2022. (i) Ohkuma, T.; Koizumi, M.; Muñiz, K.; Hilt, G.; Kabuto, C.; Noyori, R. J. Am. Chem. Soc. 2002, 124, 65086509. (j) Noyori, R. Asymmetric Catalysis in Organic Synthesis; J. Wiley \& 
Sons: New York, 1994. (k) Ojima, I. Catalytic Asymmetric Synthesis; Wiley-

VCH: New York, 2000. (1) Noyori, R. Adv. Synth. Cat. 2003, 345, 15-32.

94. (a) Newman, M. S.; Hussey, A. S. J. Am. Chem. Soc. 1947, 69, 3023-3027. (b) Armstrong, R. N.; Ammon, H. L.; Darnow, J. N. J. Am. Chem. Soc 1987, 109, 2077-2082.

95. Eliel, E. L. Stereochemistry of Carbon Compounds, McGraw-Hill Book Company, 1962.

96. Aboul-Enein, H. Y. Chiral Separations by Liquid Chromatography and Related Technologies.; Ali, Imran Published By: Marcel Dekker 2003.

97. (a) Jacques, J.; Fouquey, C. Org. Synth. 1988, 67, 1-12. (b) Jacques, J.;

Fouquey, C. Tetrahedron Lett. 1971, 12, 4617-4620. (c) Truesdale, L. K. Org. Synth. 1989, 67, 13-19.

98. (a) Wang, M.; Liu, S. Z.; Liu, J.; Hu, B. F. J. Org. Chem. 1995, 60, 7364-7365.

(b) Gong, B.; Chen, W.; Hu, B. J. Org. Chem. 1991, 56, 423-425. (c) Fabbri, D.; Delogu, G.; De Lucchi, O. J. Org. Chem. 1993, 58, 1748-1750. (d) Fabbri, D.; Delogu, G.; De Lucchi, O. J. Org. Chem. 1995, 60, 6599-6601.

99. (a) Chow, H. F.; Wan, C. W.; Ng, M. K. J. Org. Chem. 1996, 61, 8712-8714. (b)

Pakulski, Z.; Zamojski, A. Tetrahedron: Asymmetry 1995, 6, 111-115. (c) Li, Z.; Liang, X.; Wu, F.; Wan, B. Tetrahedron: Asymmetry 2004, 15, 665-669.

100. Yang, Y.; Dai, W.; Zhang, Y.; Petersen, J. L.; Wang, K. K. trahedron, 2006, $62,4364-4371$.

101. Vingiello, F. A.; Yanez, J.; Campbell, J. A. J. Org. Chem. 1971, 36, 20532056.

102. Weinreb, S. M.; Demko, D.M.; Lessen, Tetrahedron Lett. 1986, 27, 20992102.

103. Zhang, H. -R. Ph. D. Thesis, West Virginia University 2000.

104. (a) Landor, P. D. in The Chemistry of the Allenes; Landor, S. R. Ed.; Acadamic Press: London 1982, Vol. 1, pp 44-47. (b) Kuhn, R.; Rewicki, D. 
Chem. Ber. 1965, 98, 2611-2618.

105. (a) J. Lu, Y. Bai, Z. Wang, B. Yang, W. Li, Synth. Commun. 2001, 31, 26252630. (b) Ramachary, D. B.; Kishor, M.; Reddy, G. B. Org. Biomol. Chem., 2006, 4, 1641-1646.

106. Jung, M. E.; Lyster, M. A. J. Org. Chem. 1977, 42, 3761-3764.

107. (a) Enholm, E. J.; Jiang, S. Heterocycles 1992, 34, 2247-2252. (b) Enholm, E. J.; Jiang, S. Tetrahedron Lett. 1992, 33, 6069-6072. (c) Enholm, E. J.; Jiang, S.; Abboud, K. J. Org. Chem. 1993, 58, 4061-4069. (d) Inanaga, J.; Sugimoto, Y.; Hanamoto, T. Tetrahedron Lett. 1992, 33, 7035-7038. (e) Aurrecoechea, J. M.; Anton, R. F.-S. J. Org. Chem. 1994, 59, 702-704. (f) Lange, G. L.; Gottardo, C. Tetrahedron Lett. 1994, 35, 6607-6609.

108. Sosnowski, J. J.; Danater, E. B.; Murray, R. K. J. Org. Chem. 1985, 50, 27592763.

109. Barner, B.A.; Liu, Y.; Rahman, M.A. Tetrahedron 1989, 45, 6101-6112.

110. Rice, J. E.; Cai, Z.-W. J. Org. Chem. 1993, 58, 1415-1424. 


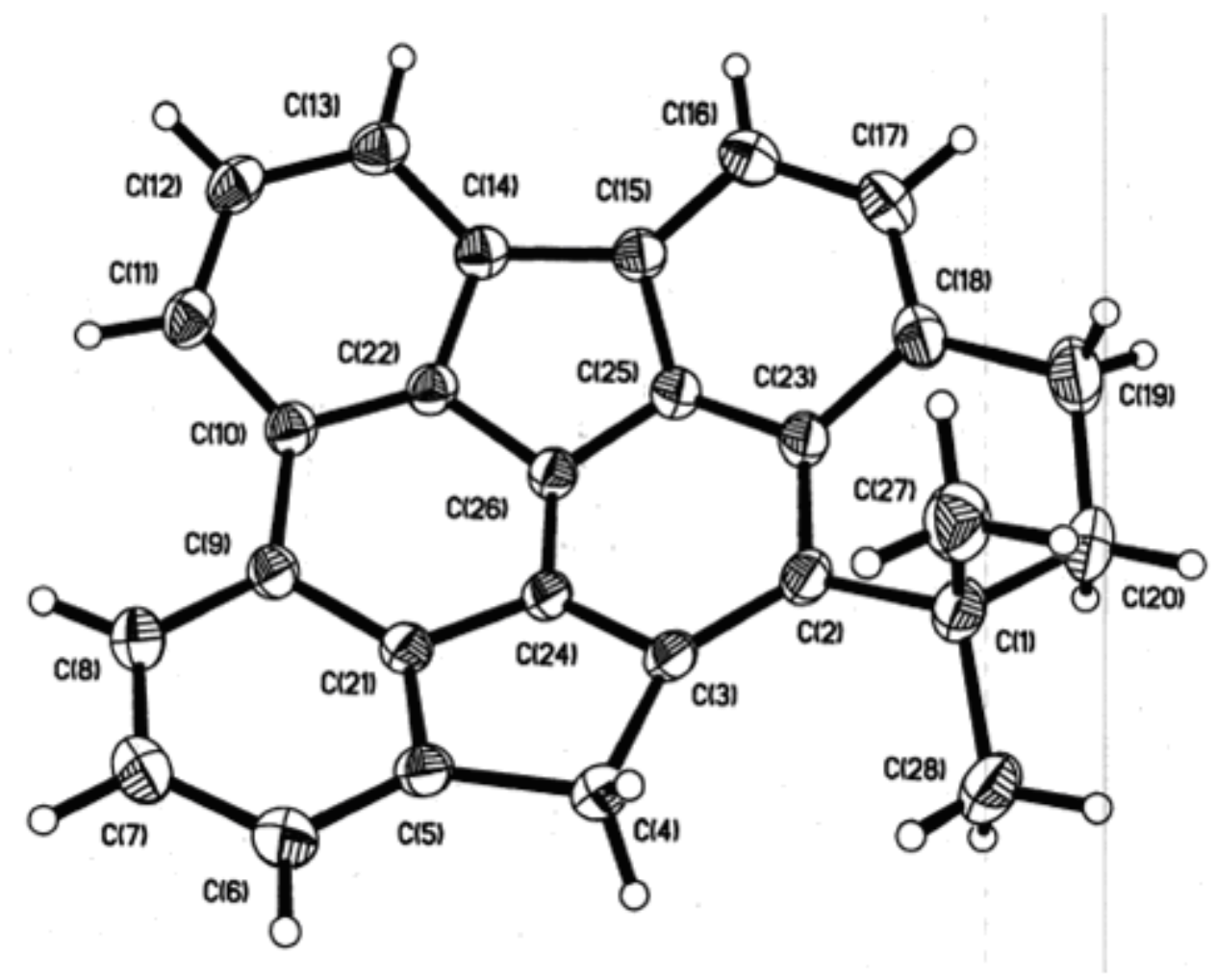

Figure 26. ORTEP drawing of the crystal structure of Buckybowl 148a.

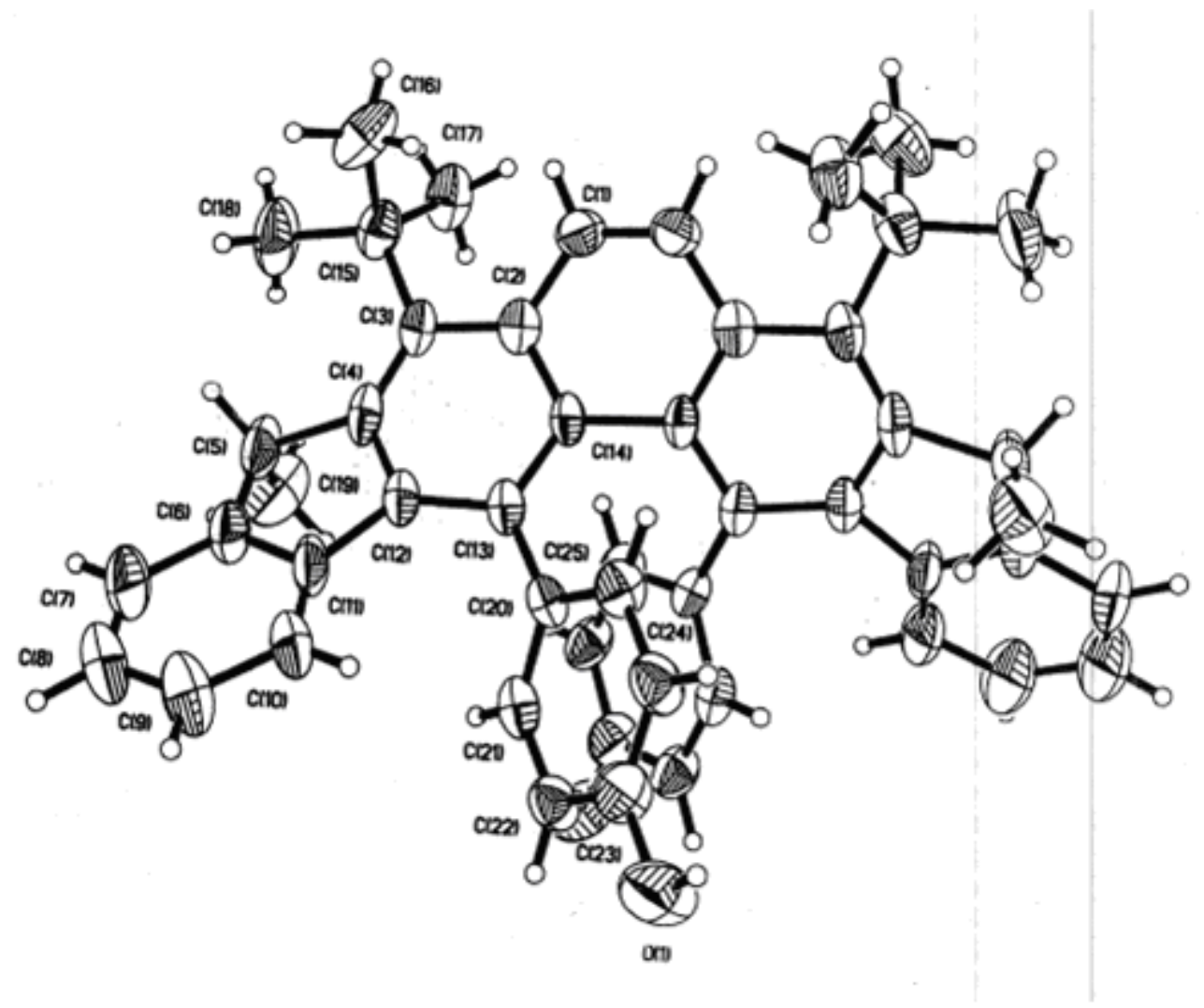

Figure 27. ORTEP drawing of the crystal structure of 4,5-diphenolicphenanthrene 177. 


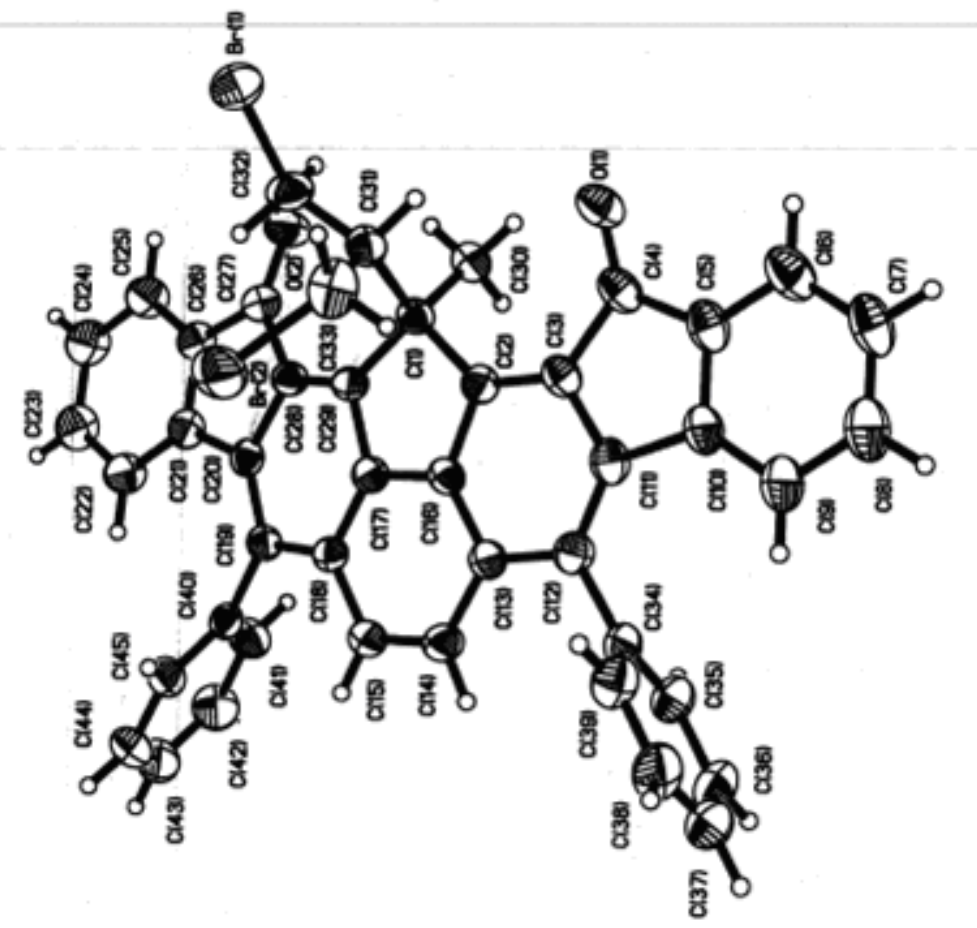

Figure 28. ORTEP drawing of the crystal structure of Dibromoketone 252.

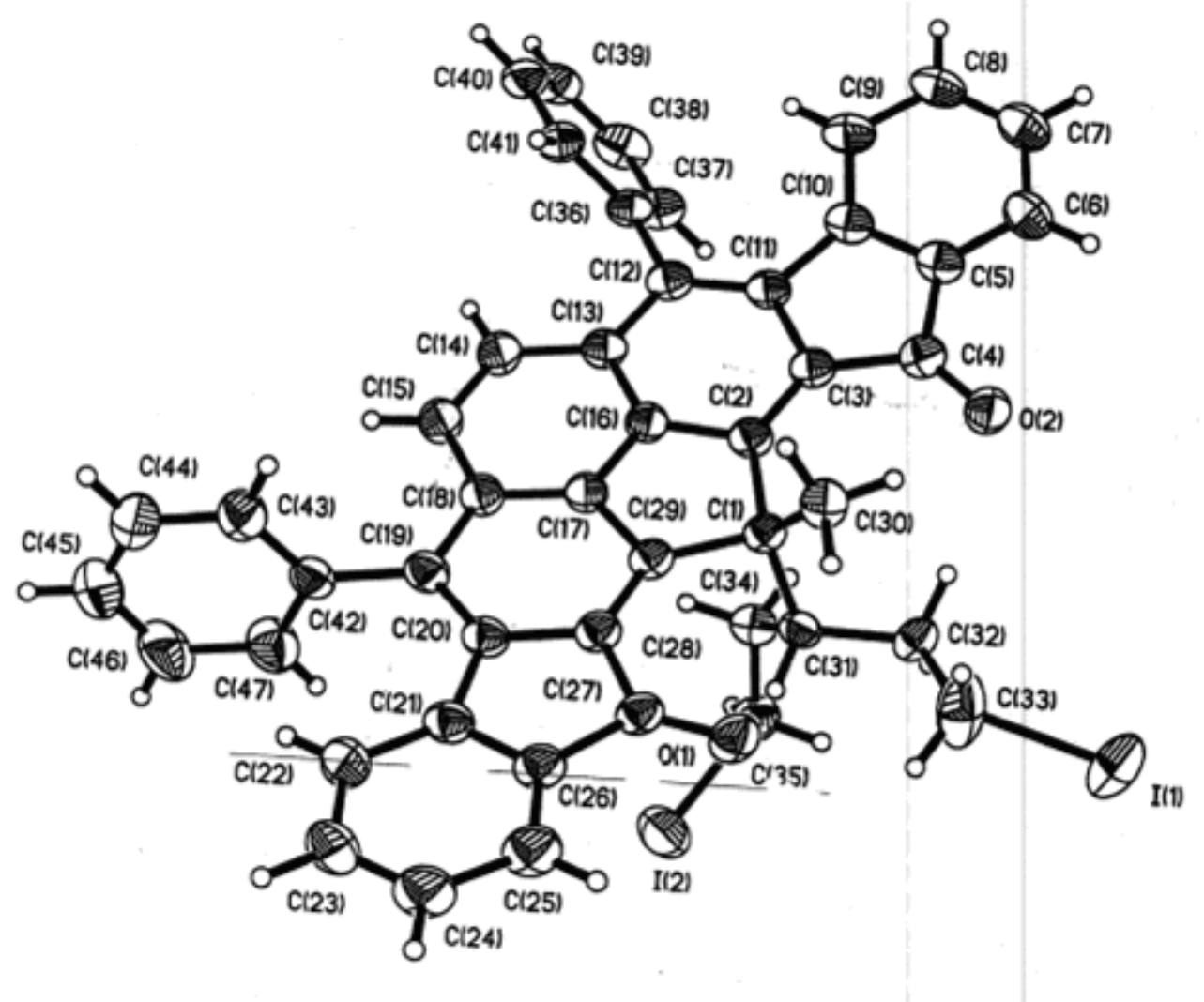

Figure 29. ORTEP drawing of the crystal structure of Diiodoketone 254. 


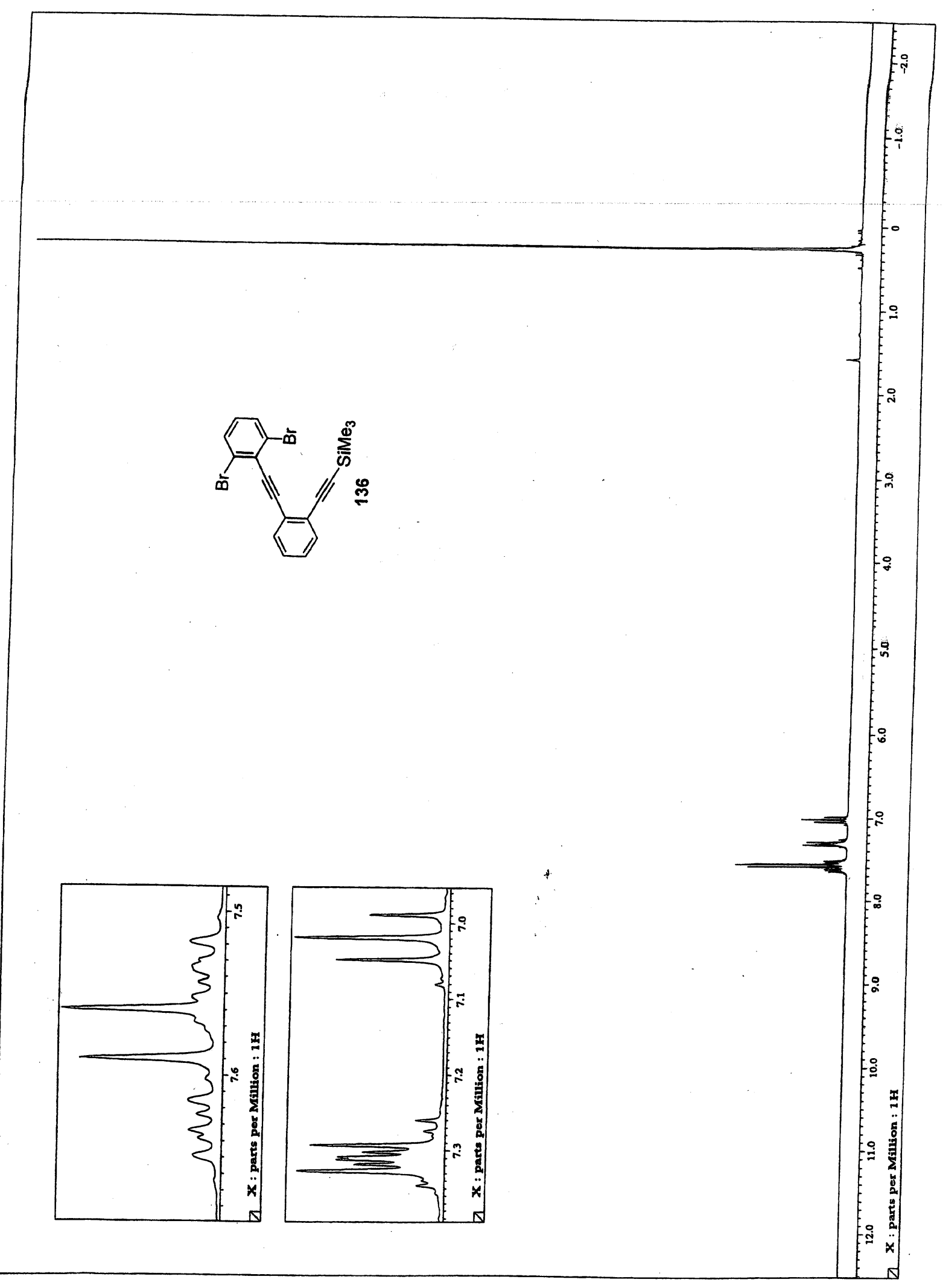




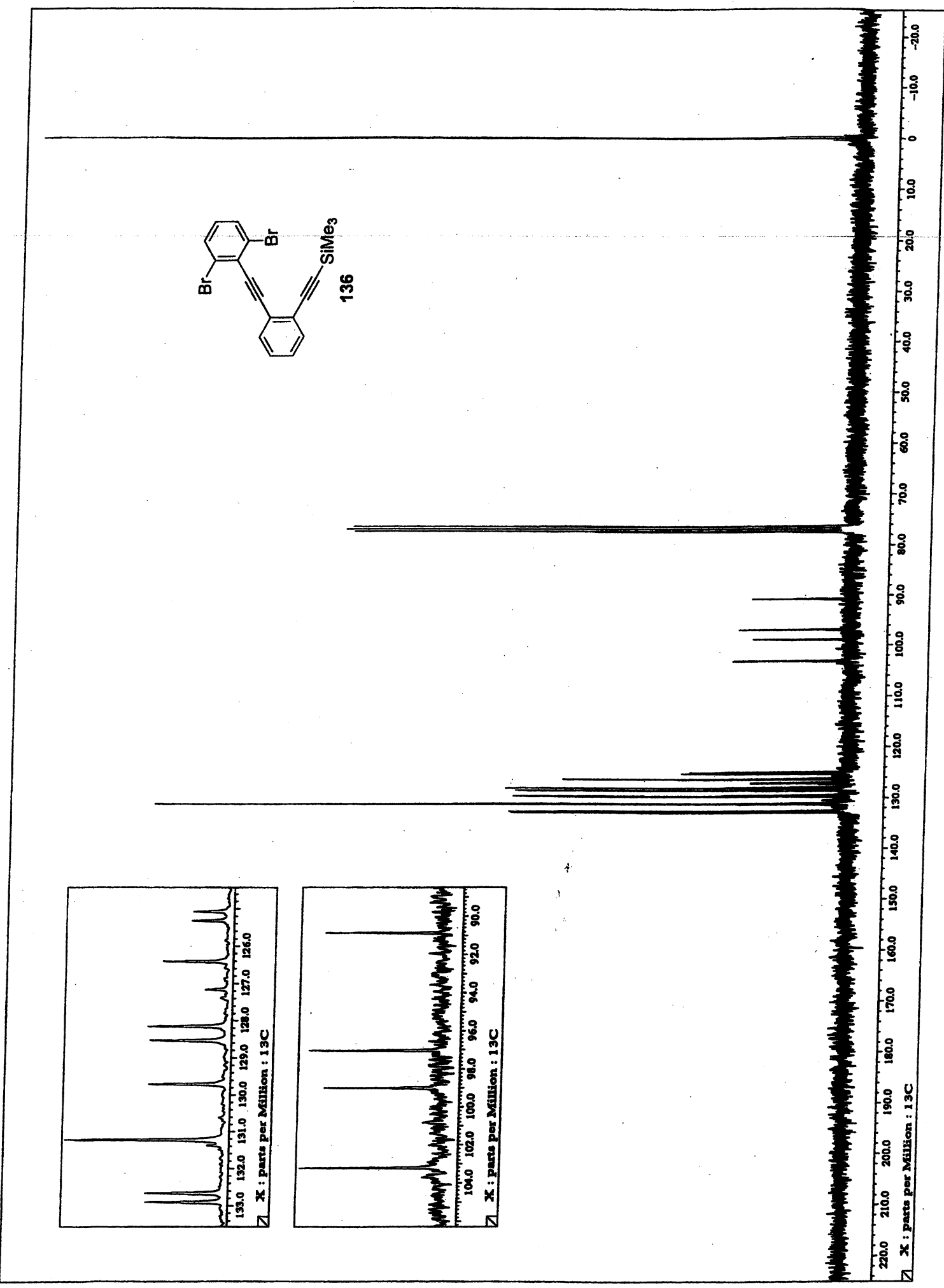




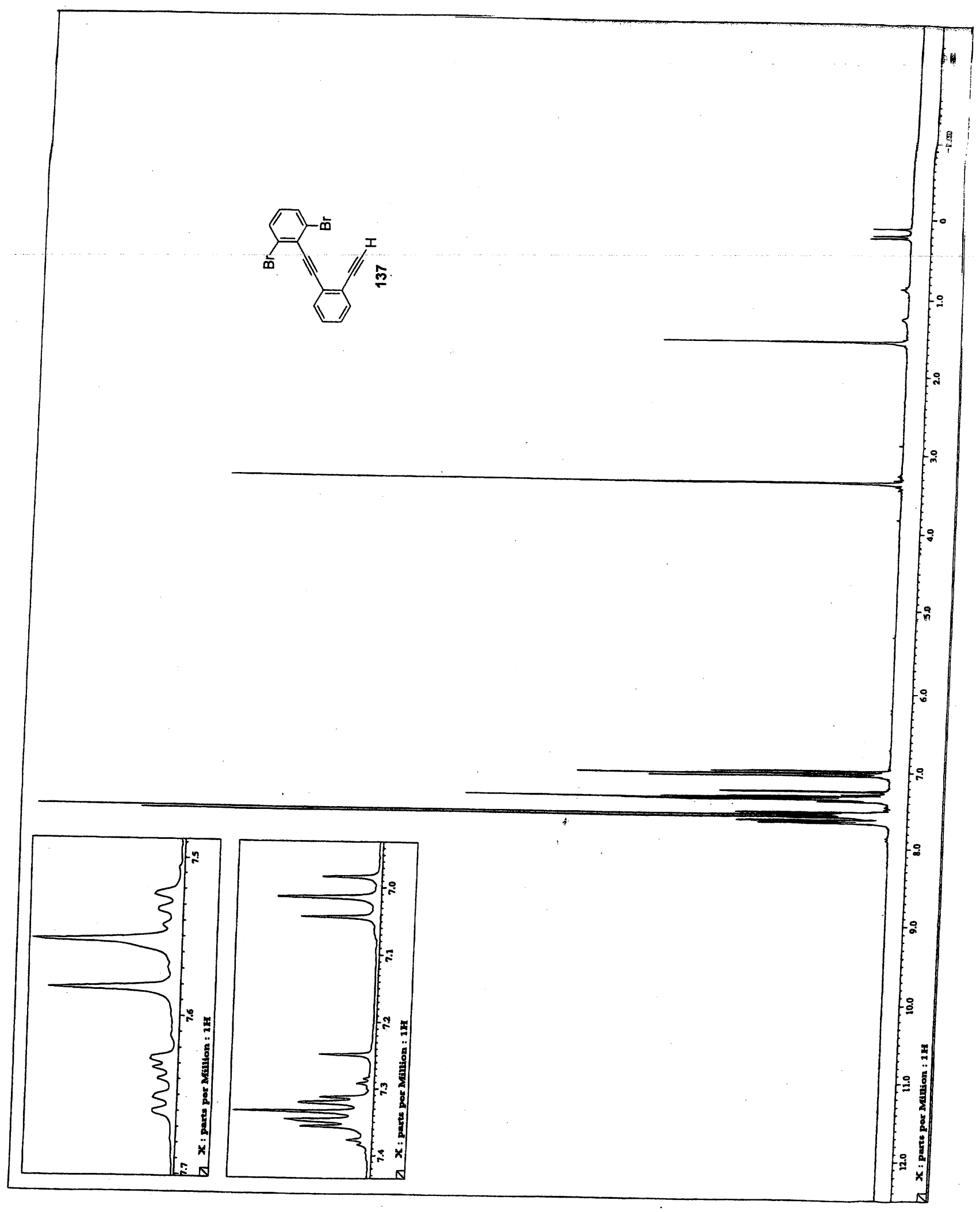




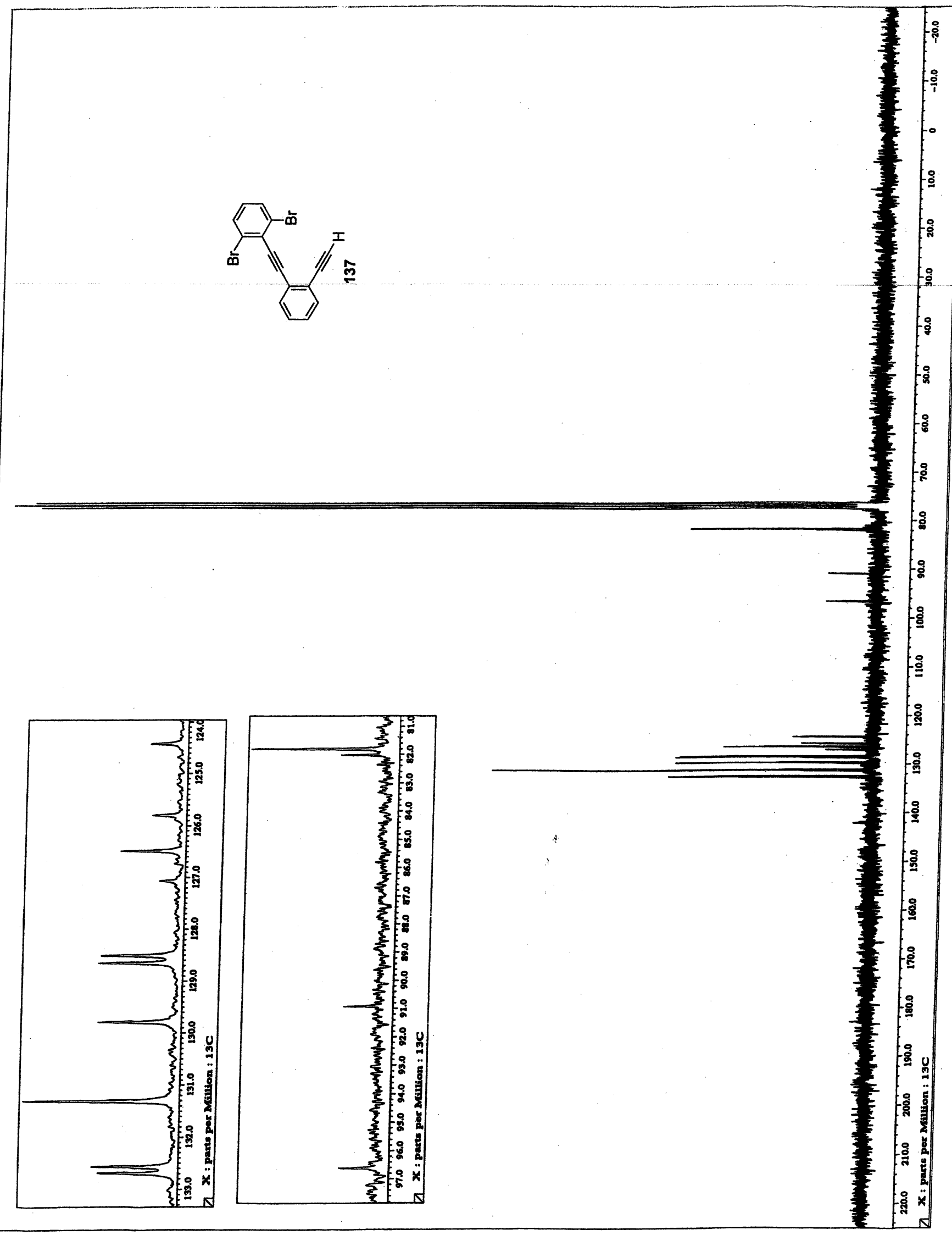




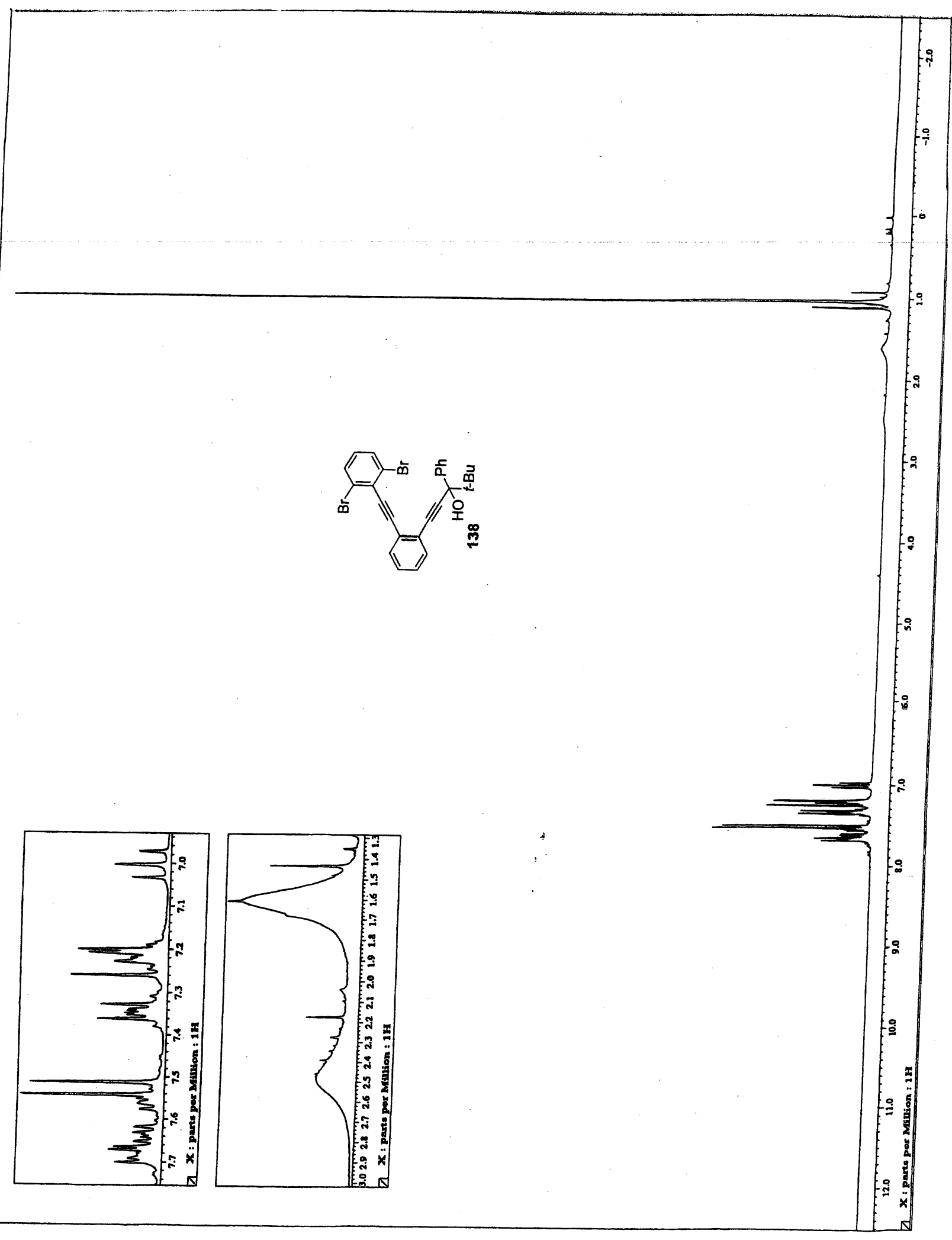




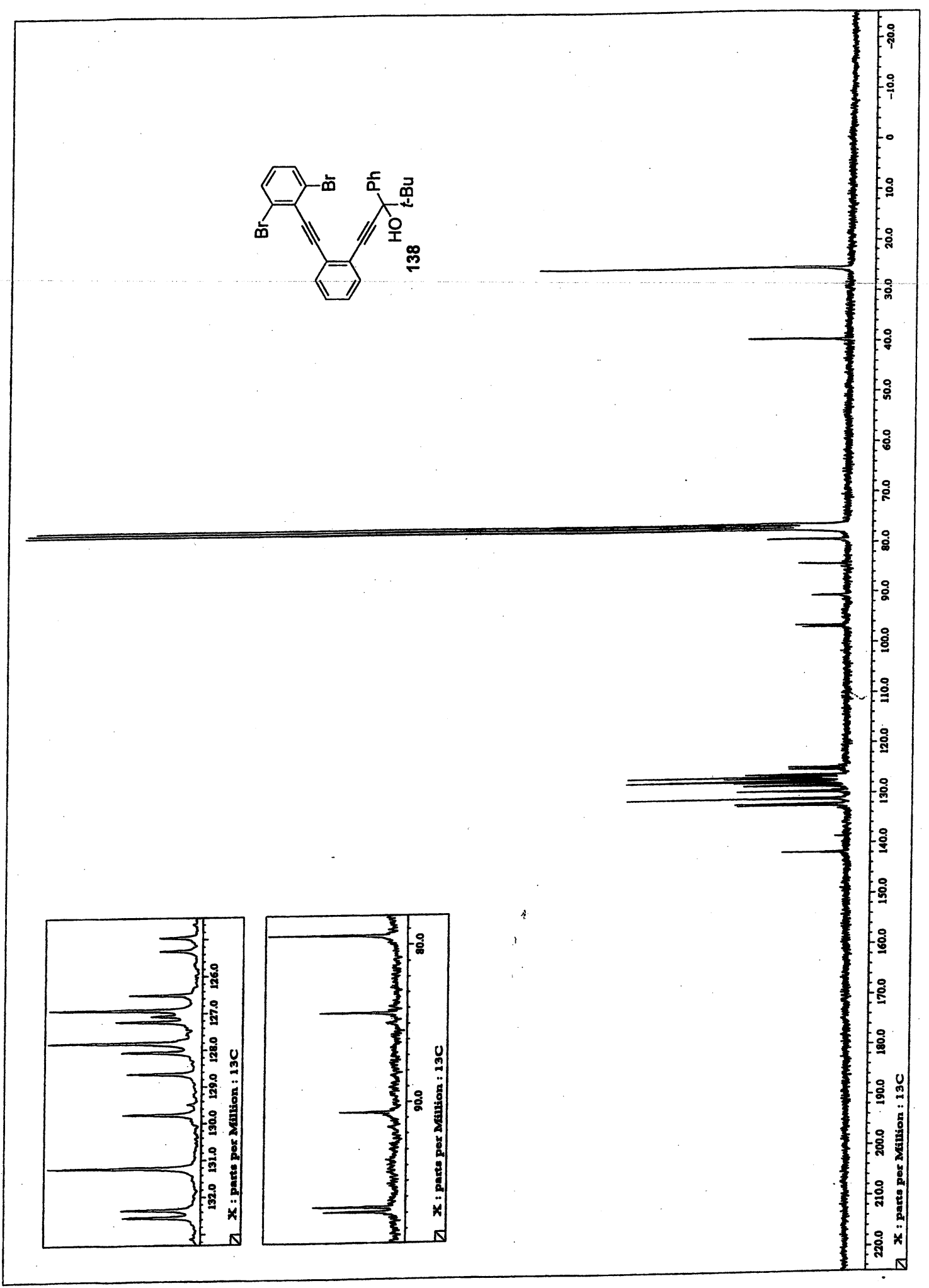




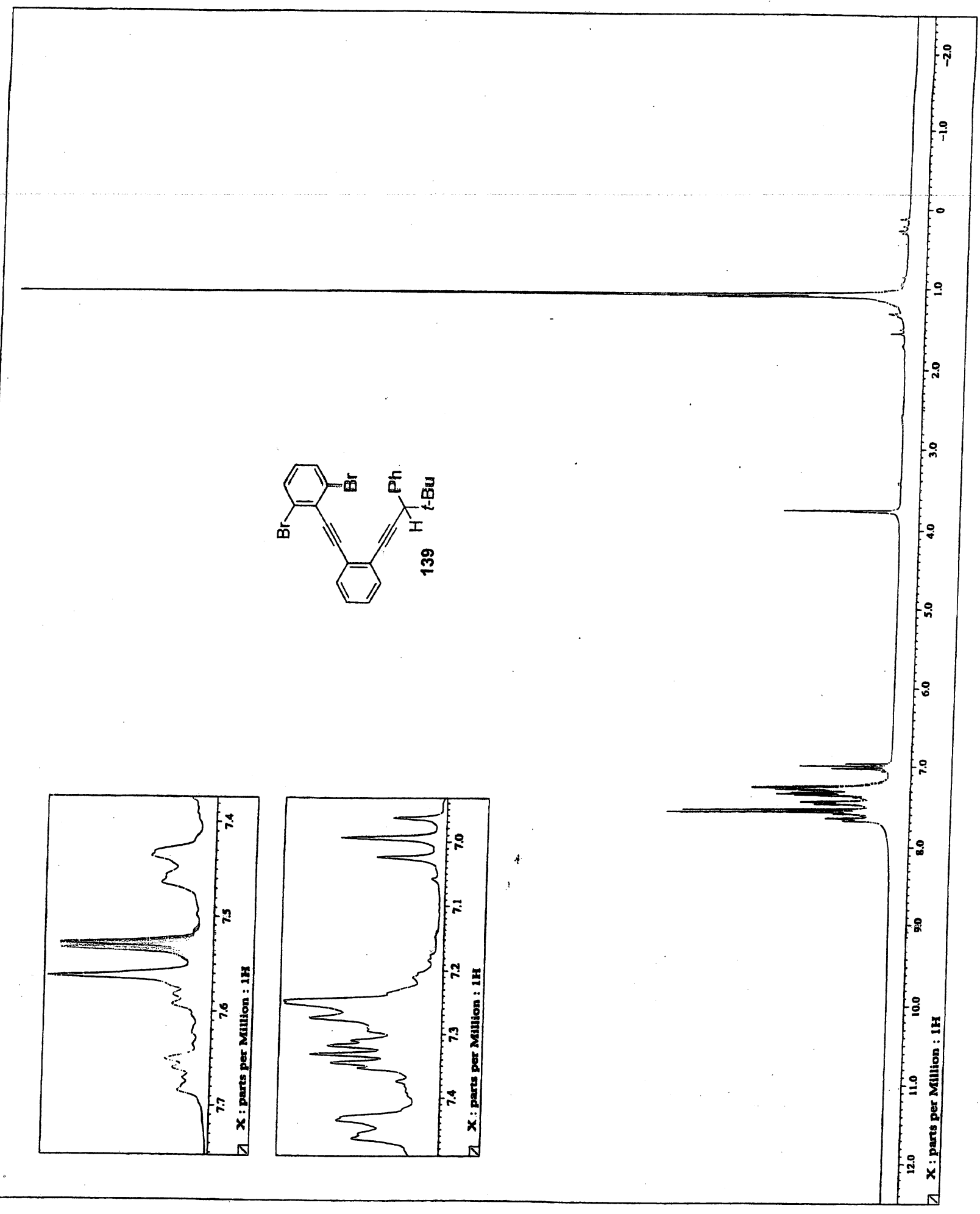




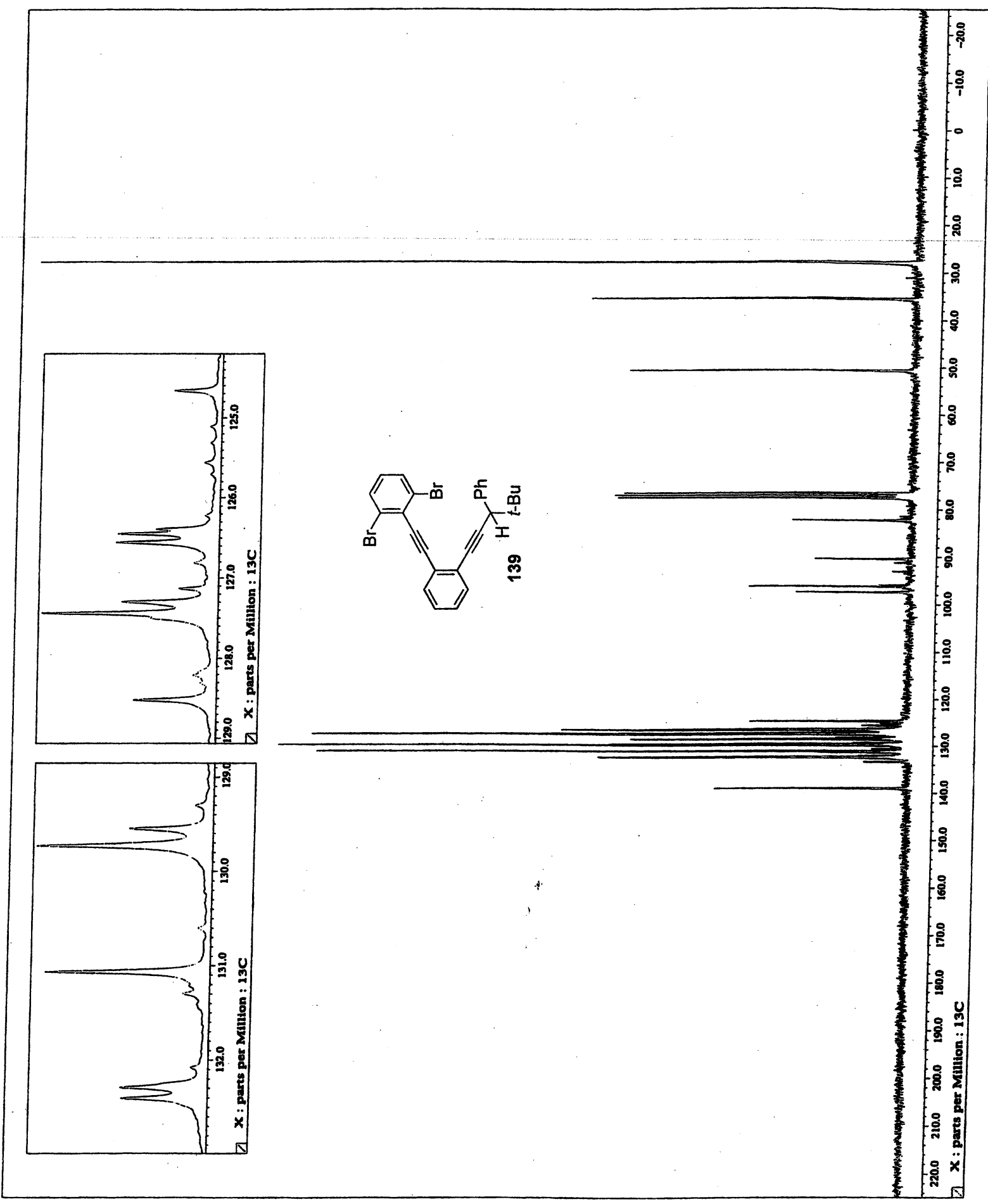




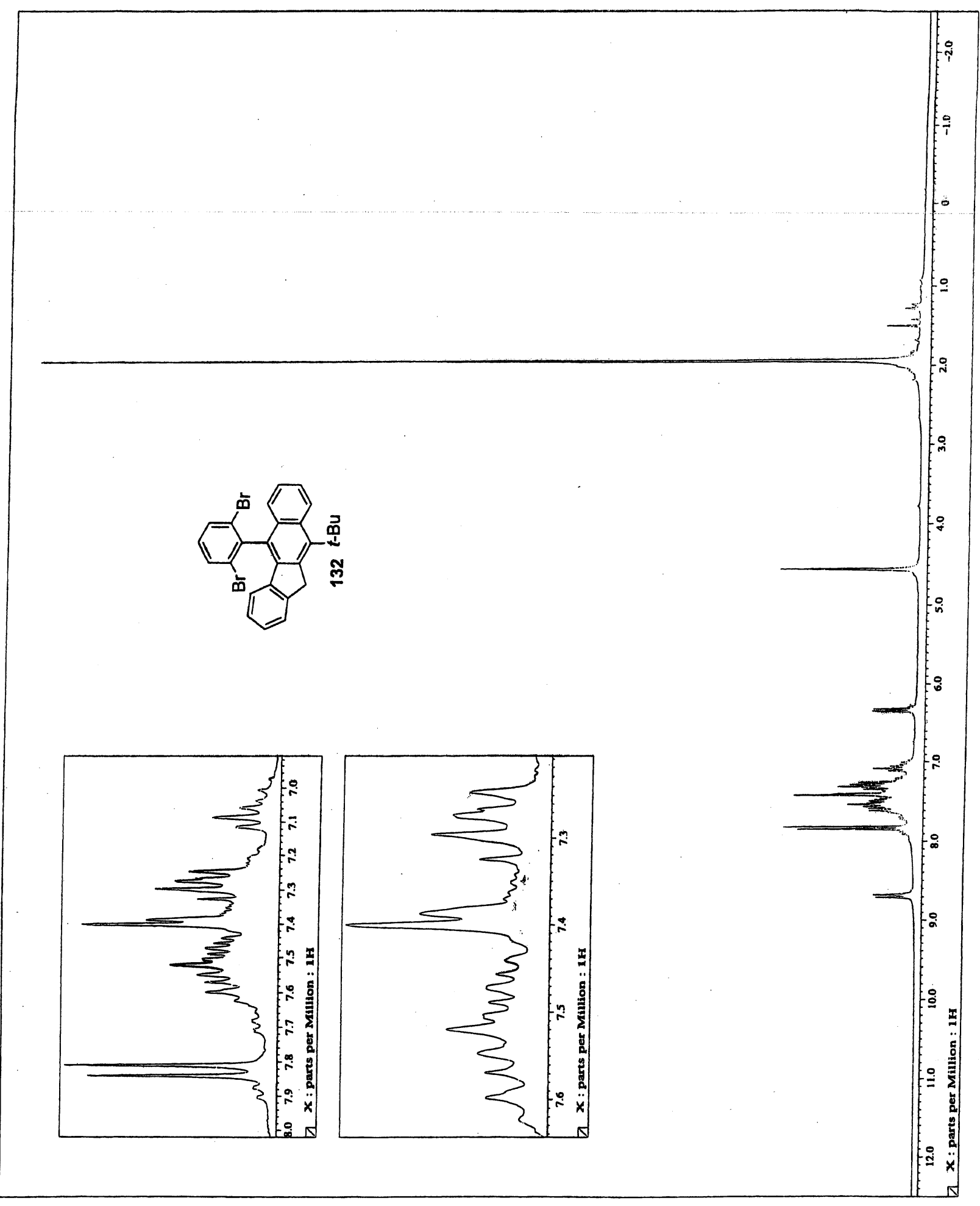




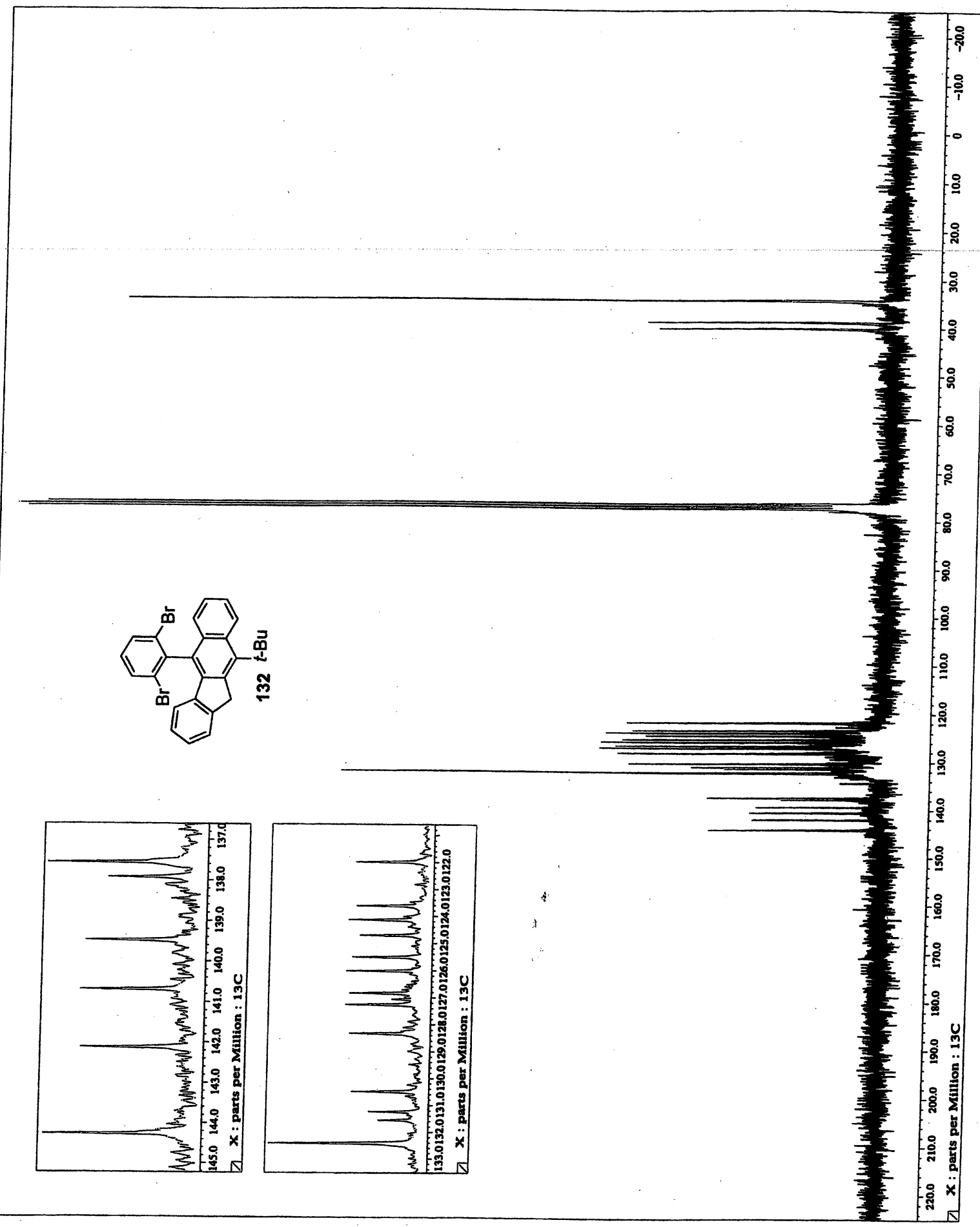





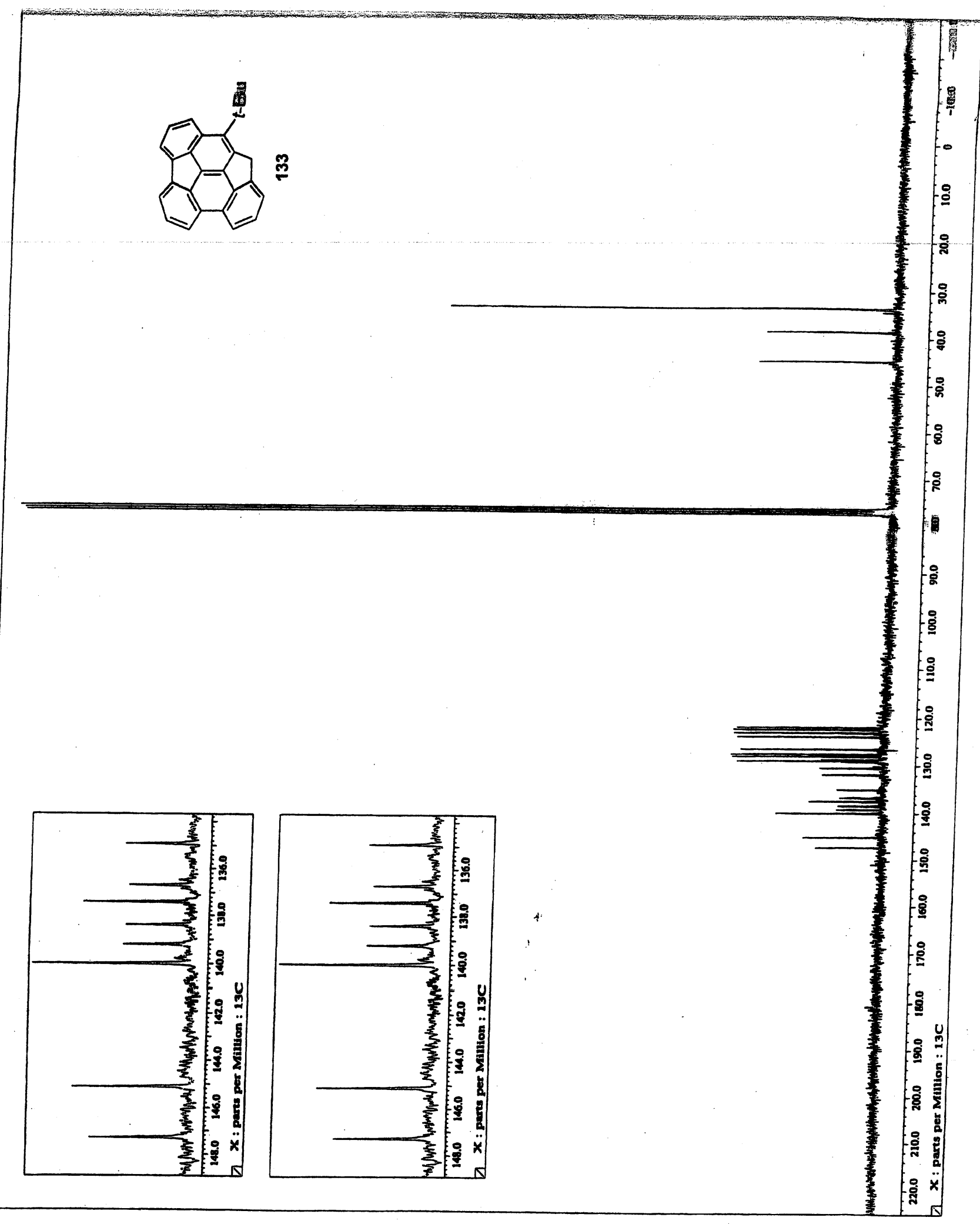




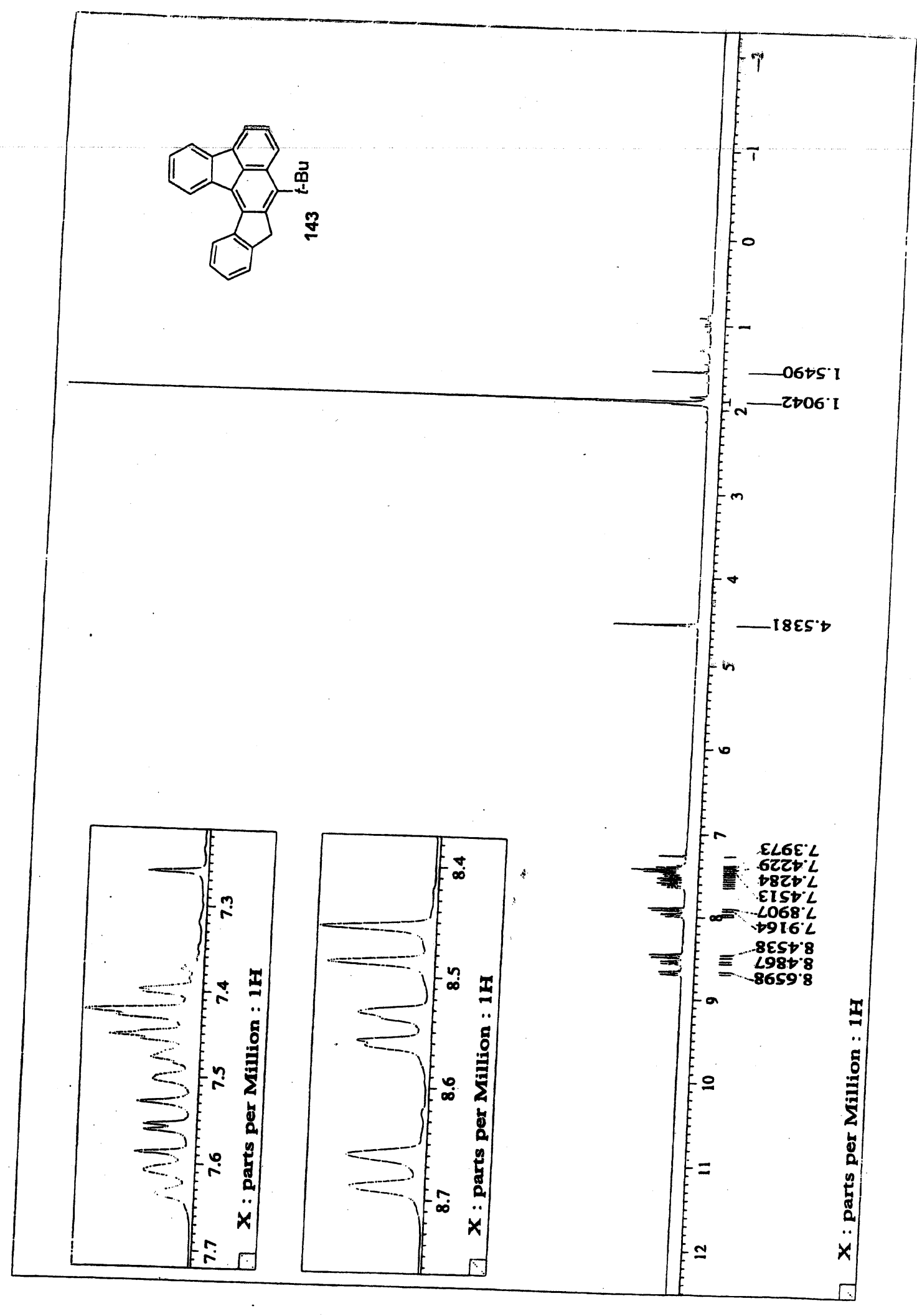




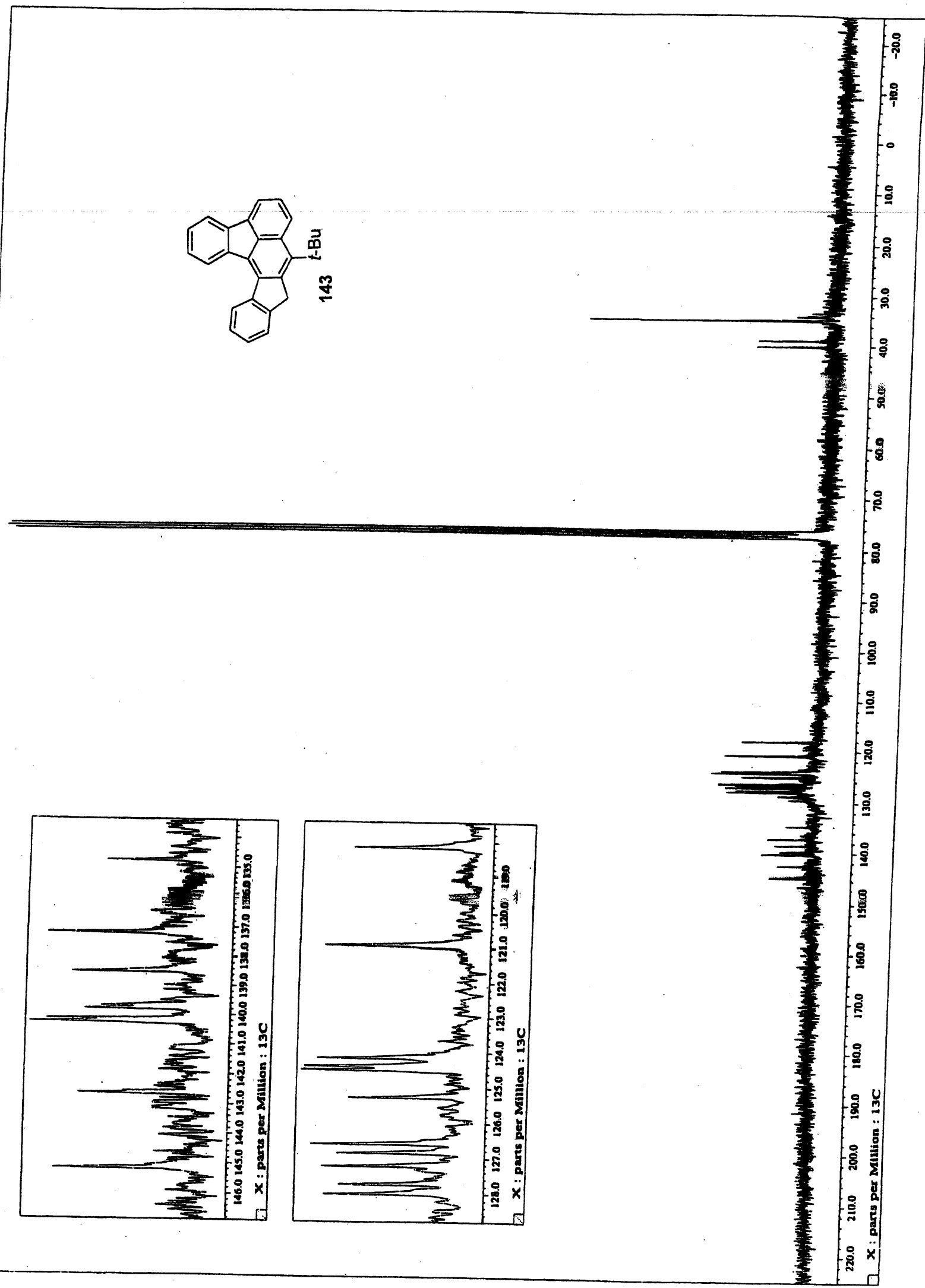




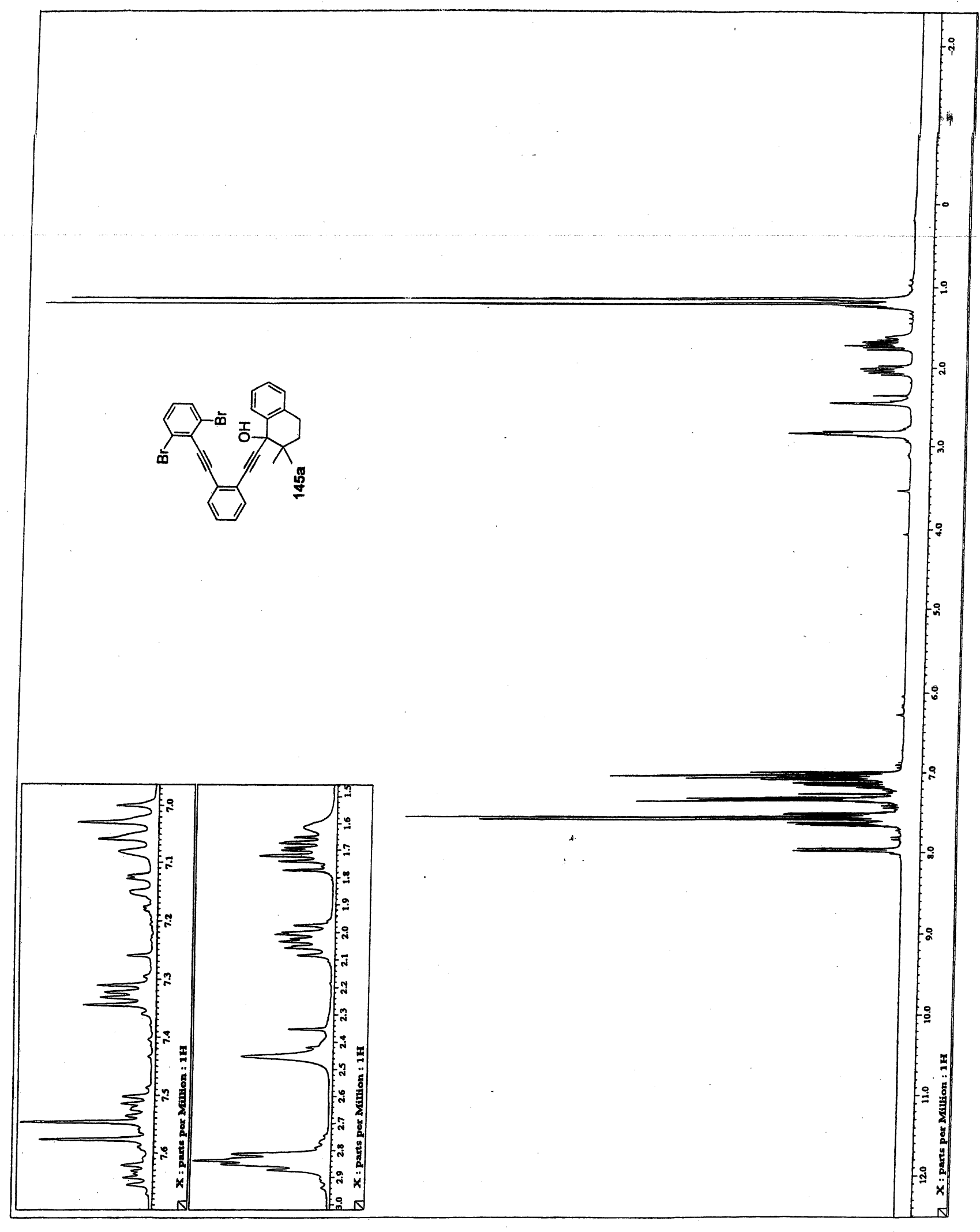




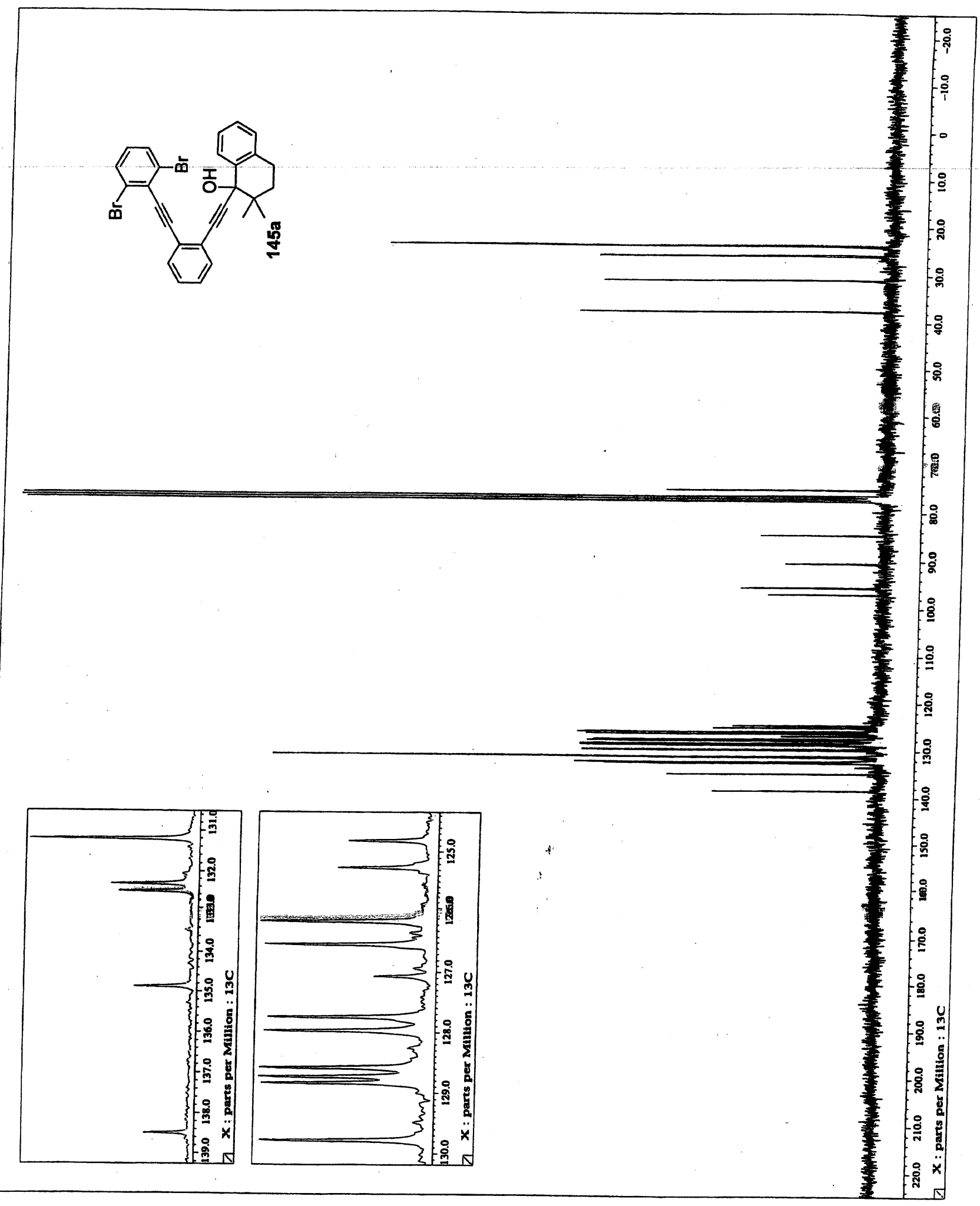




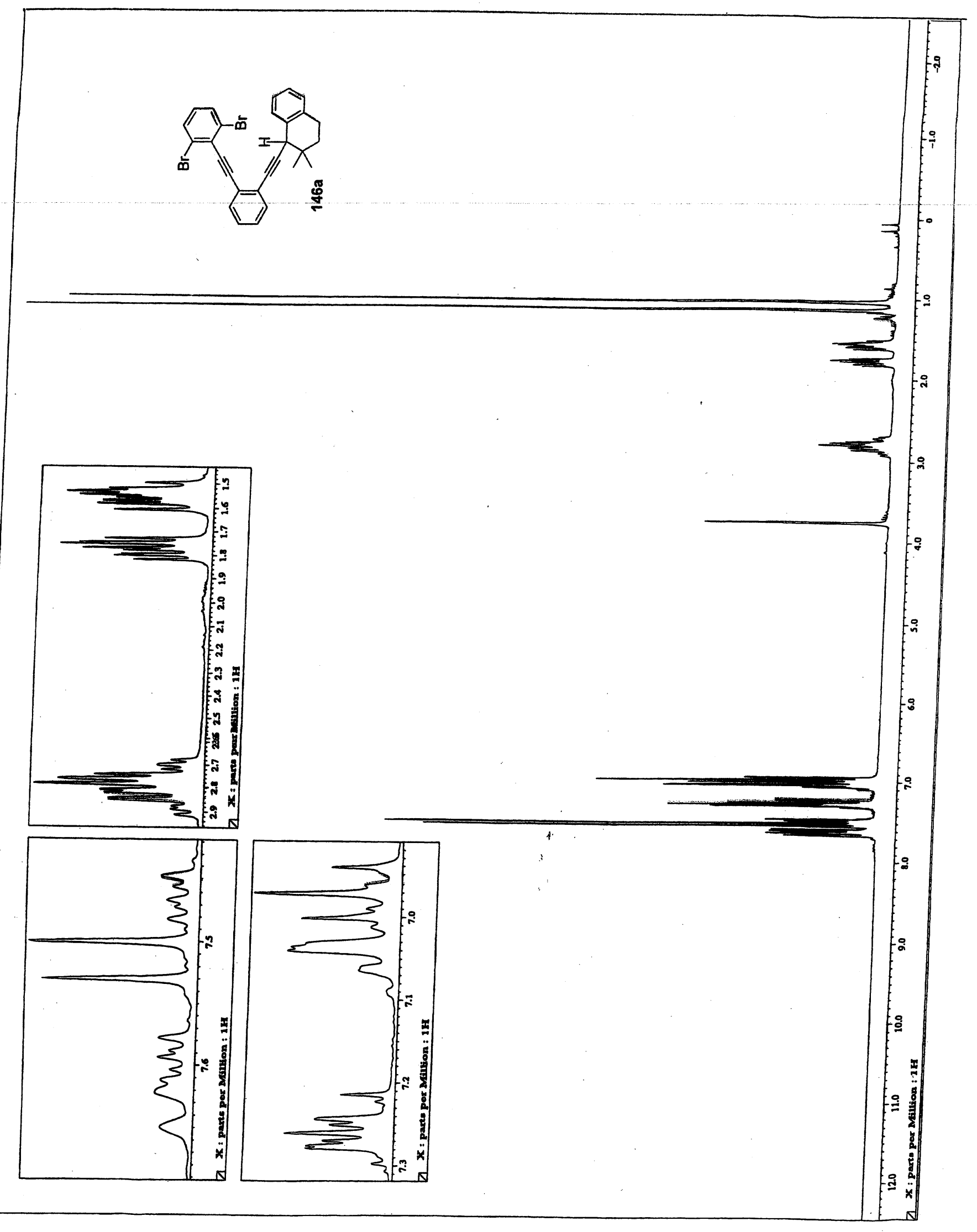




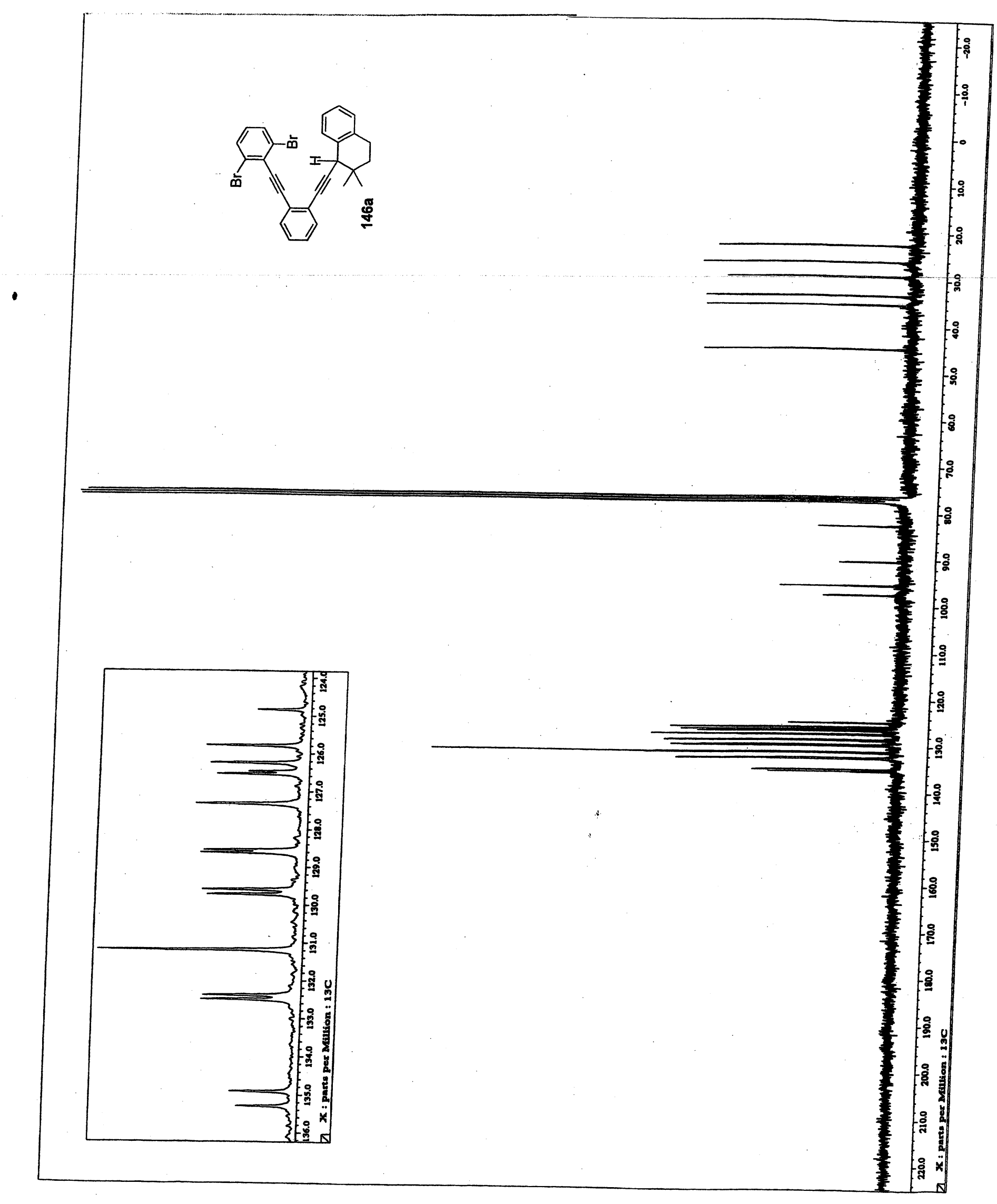




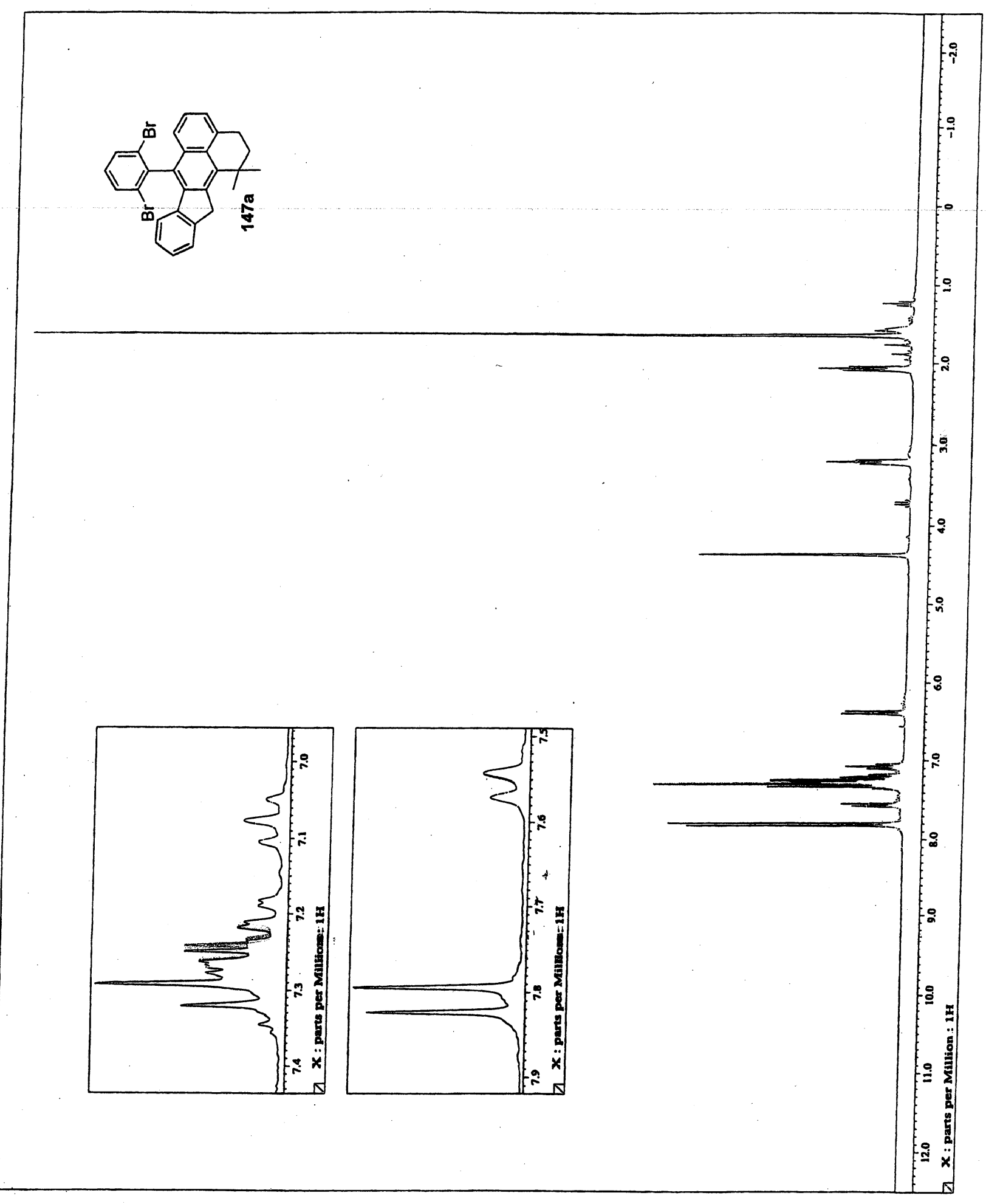




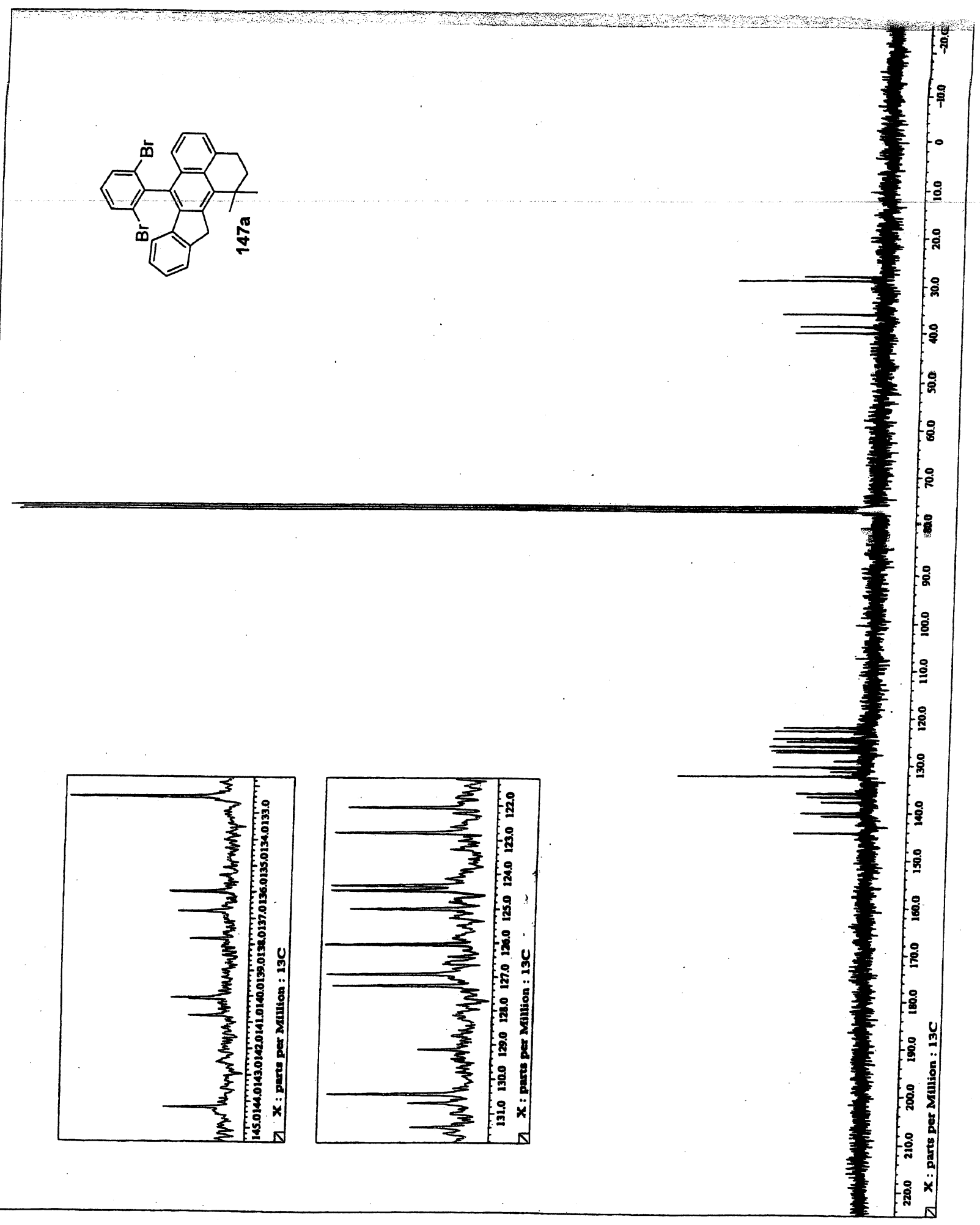




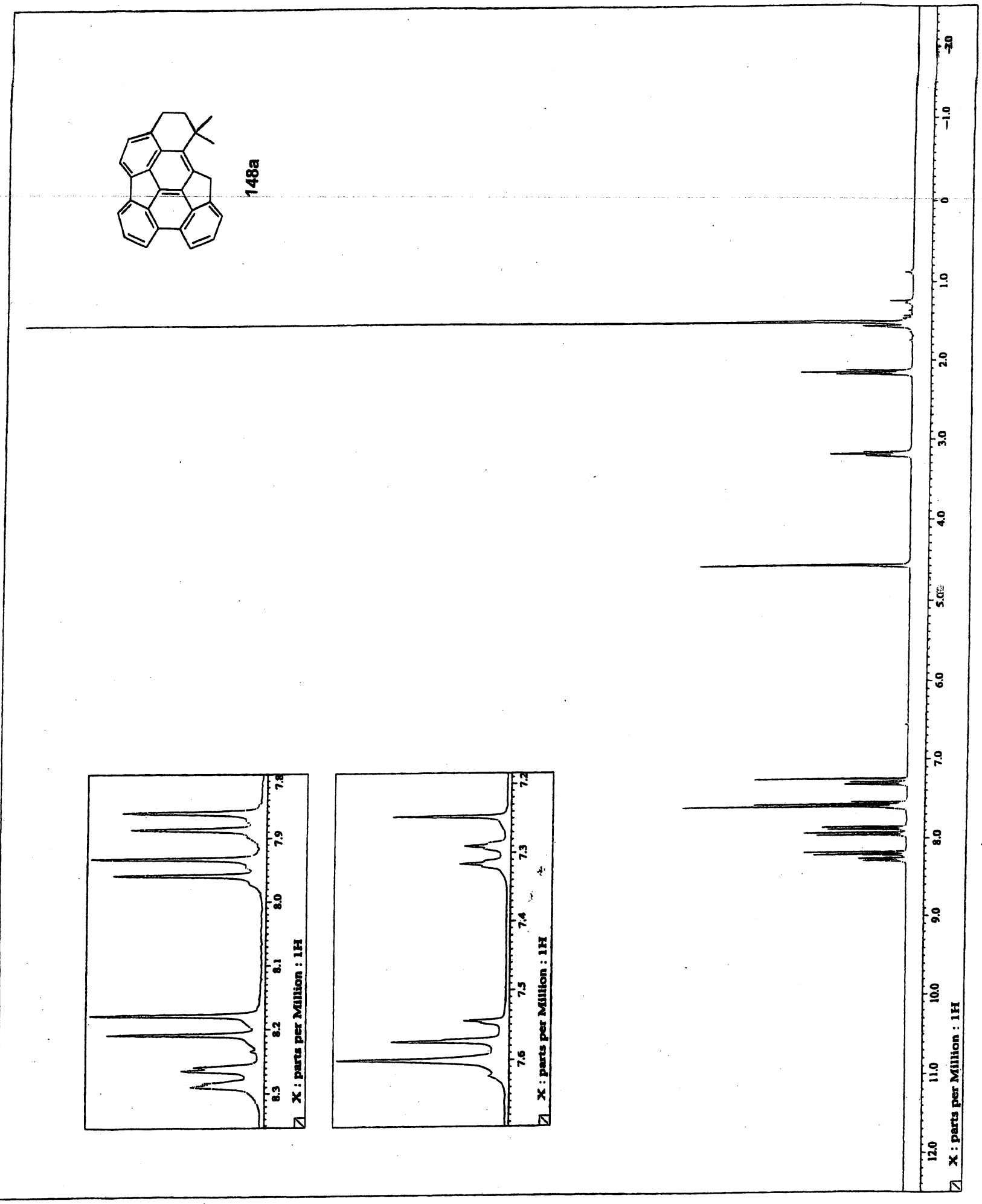




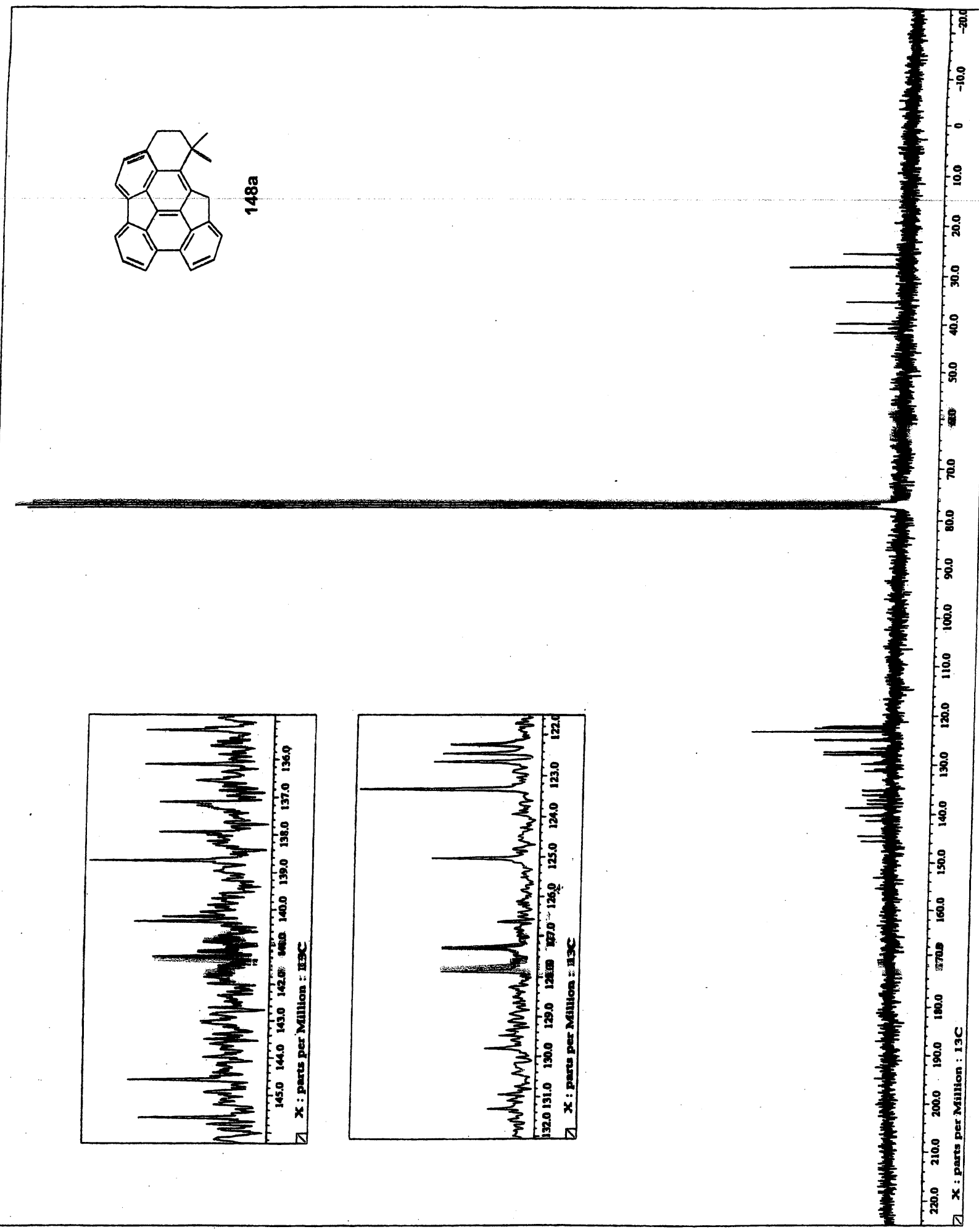




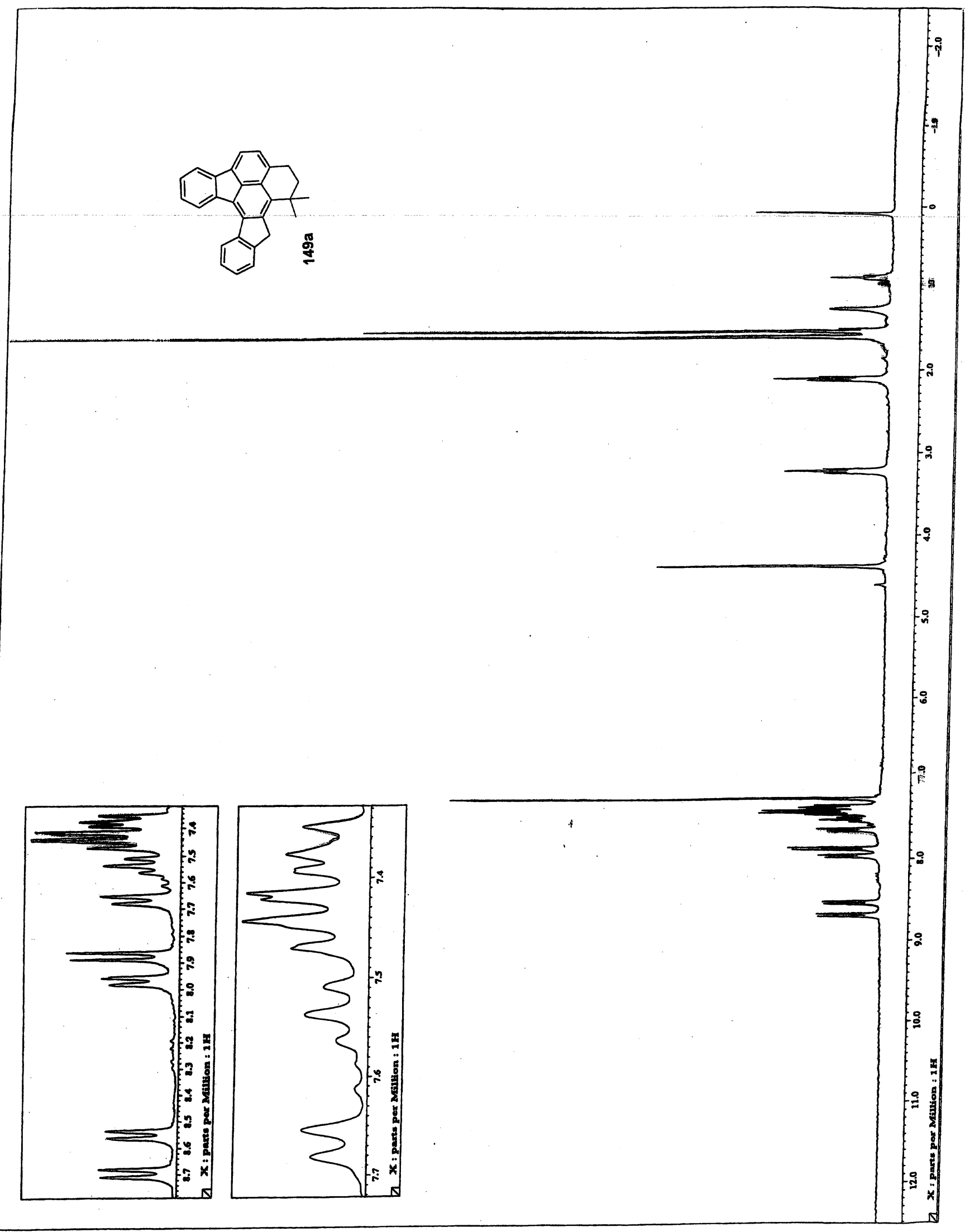




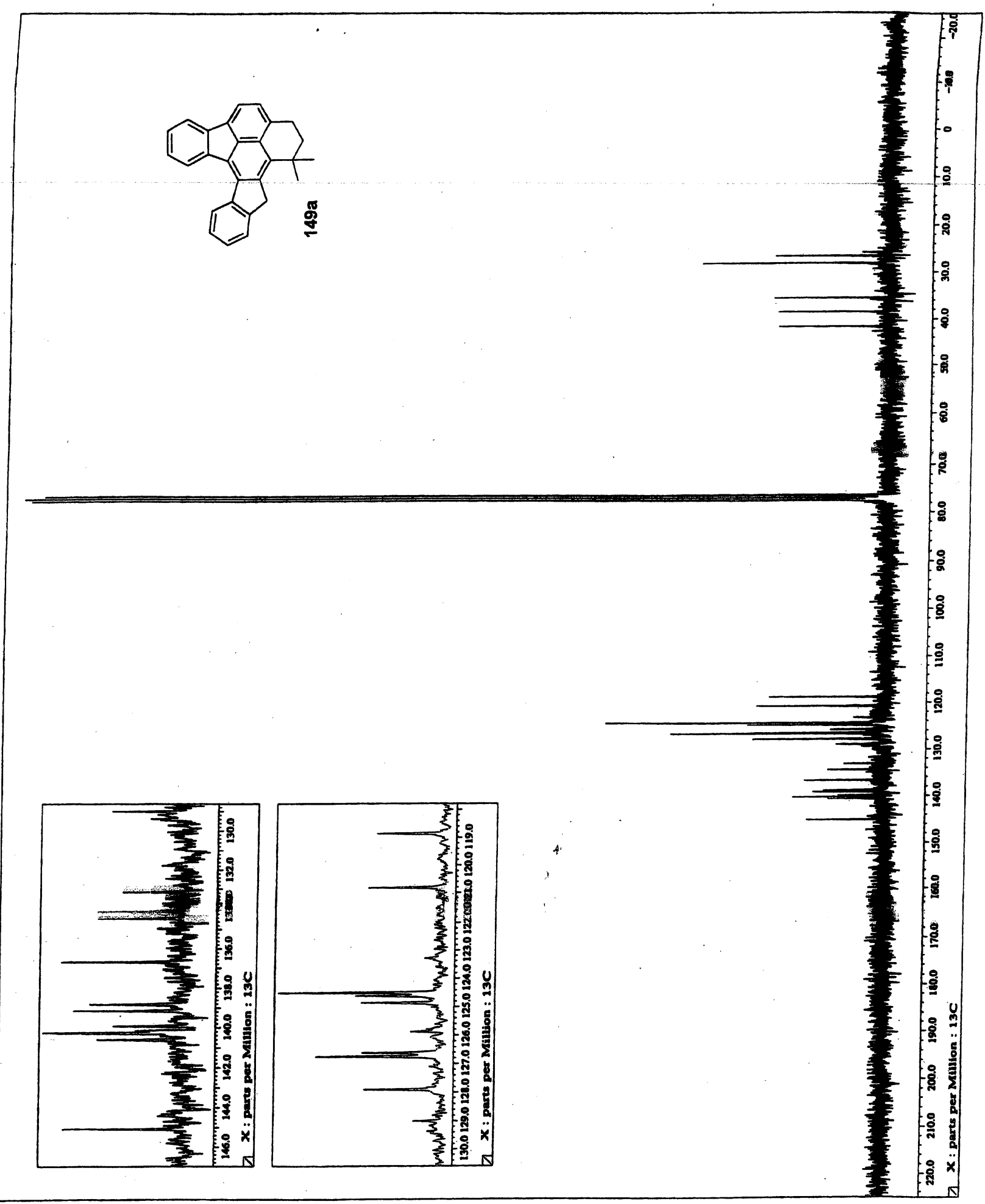




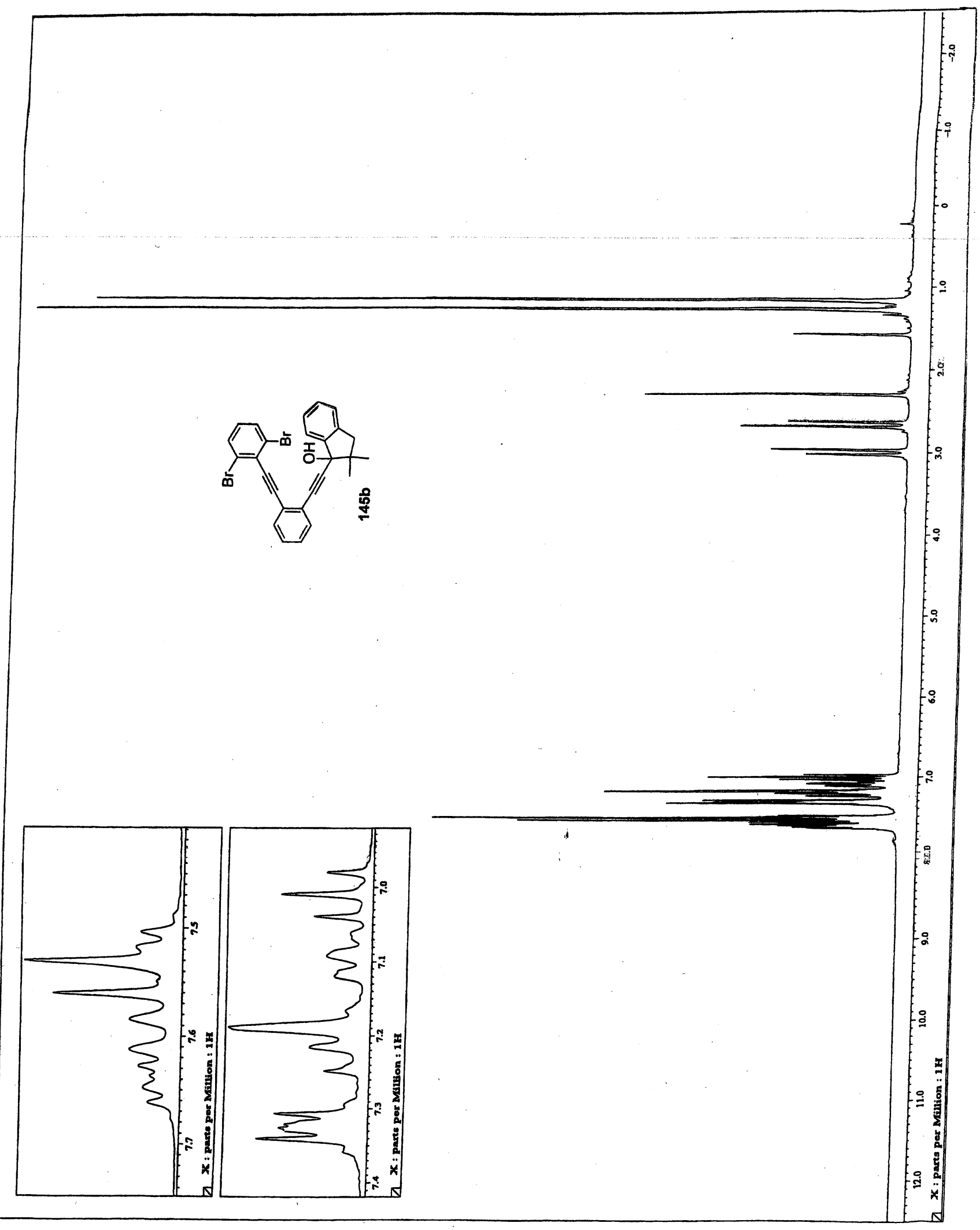




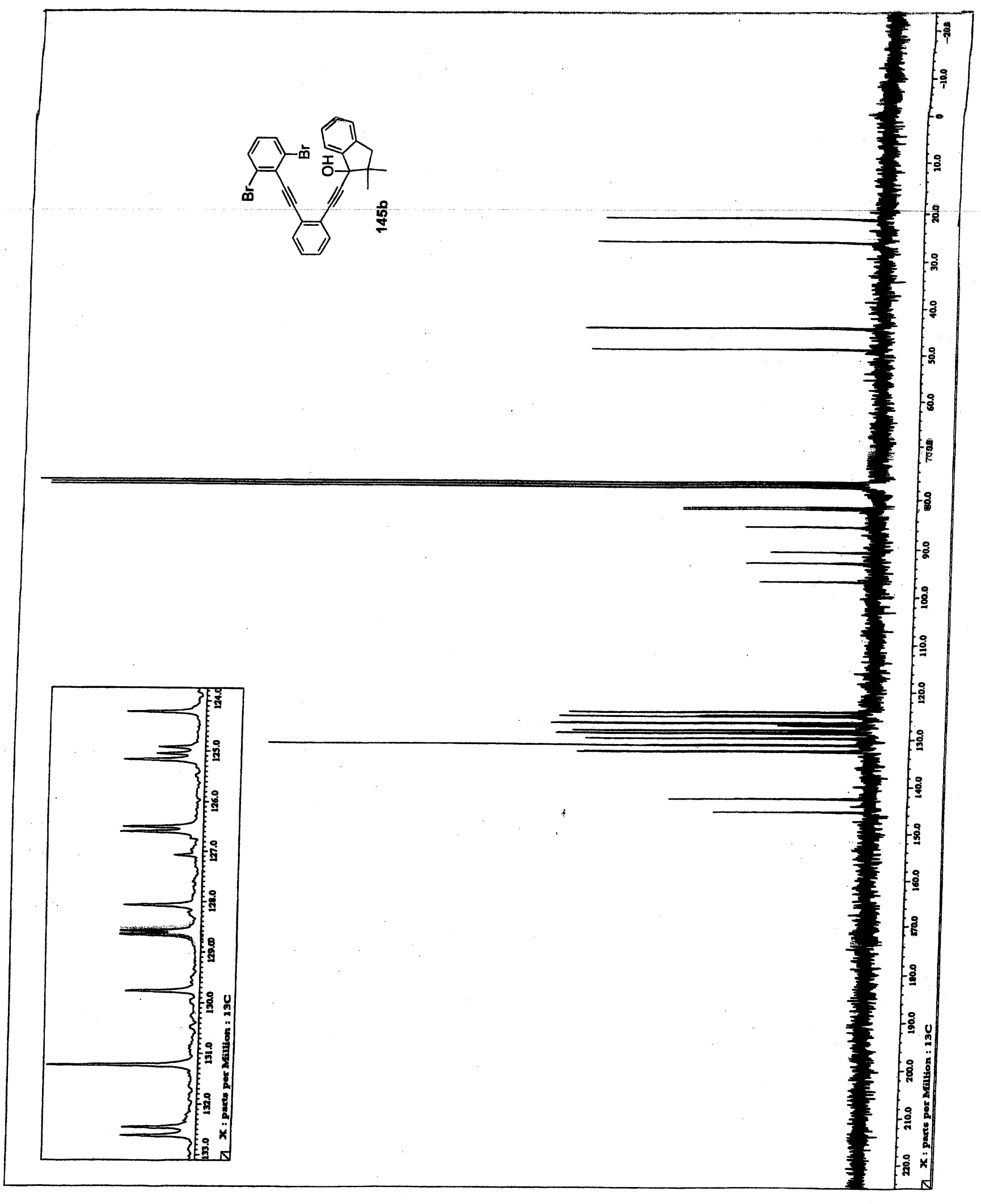




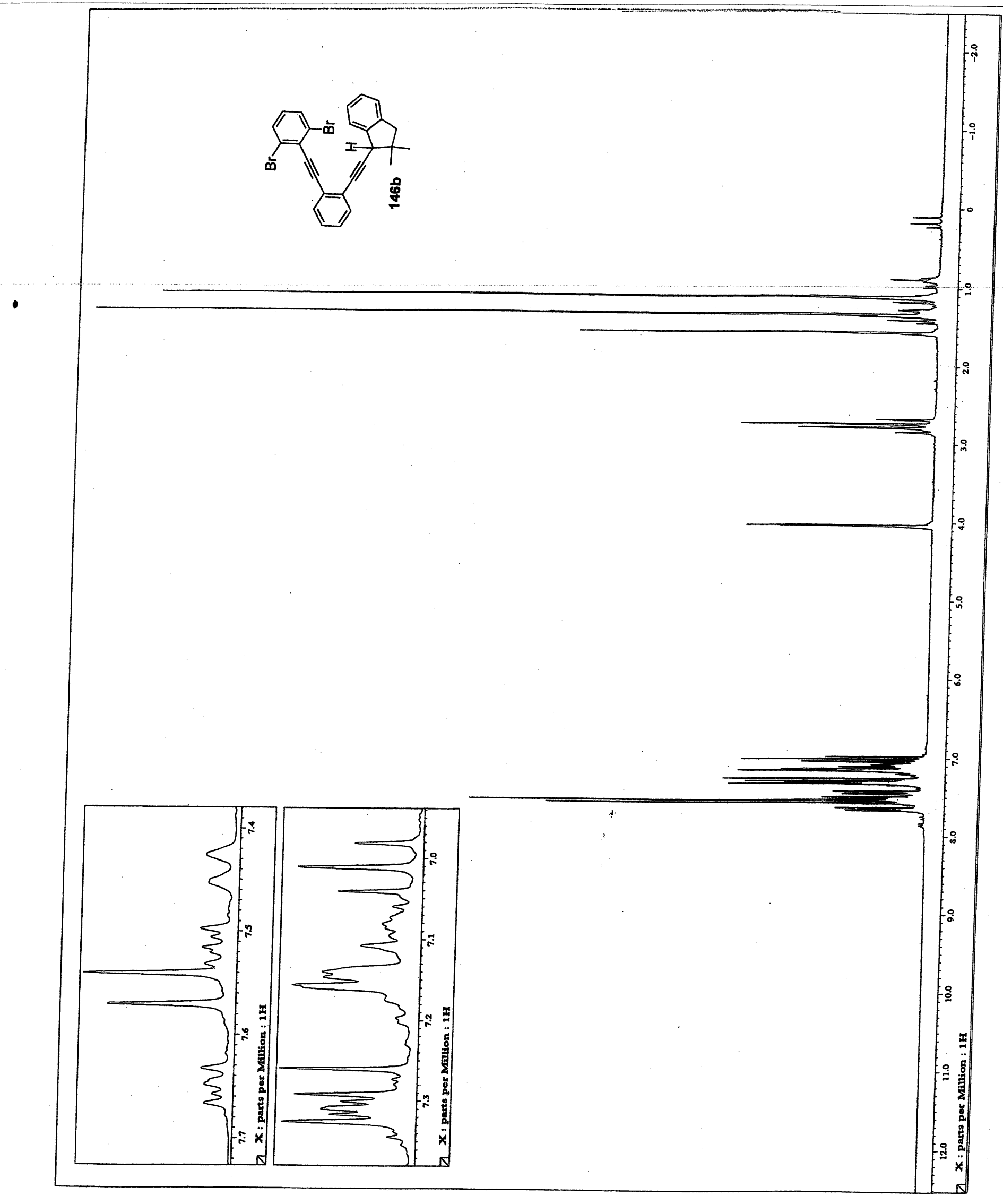




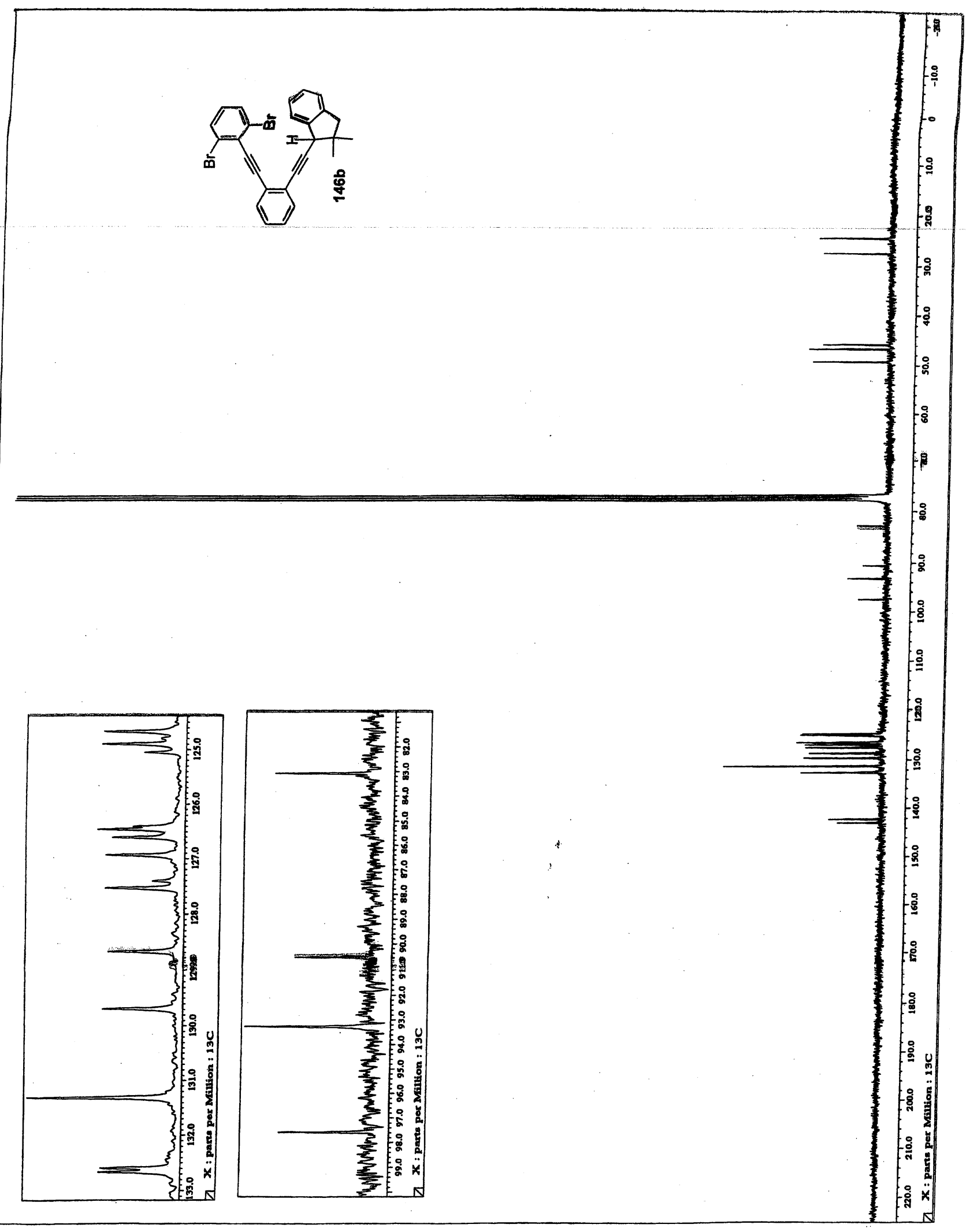




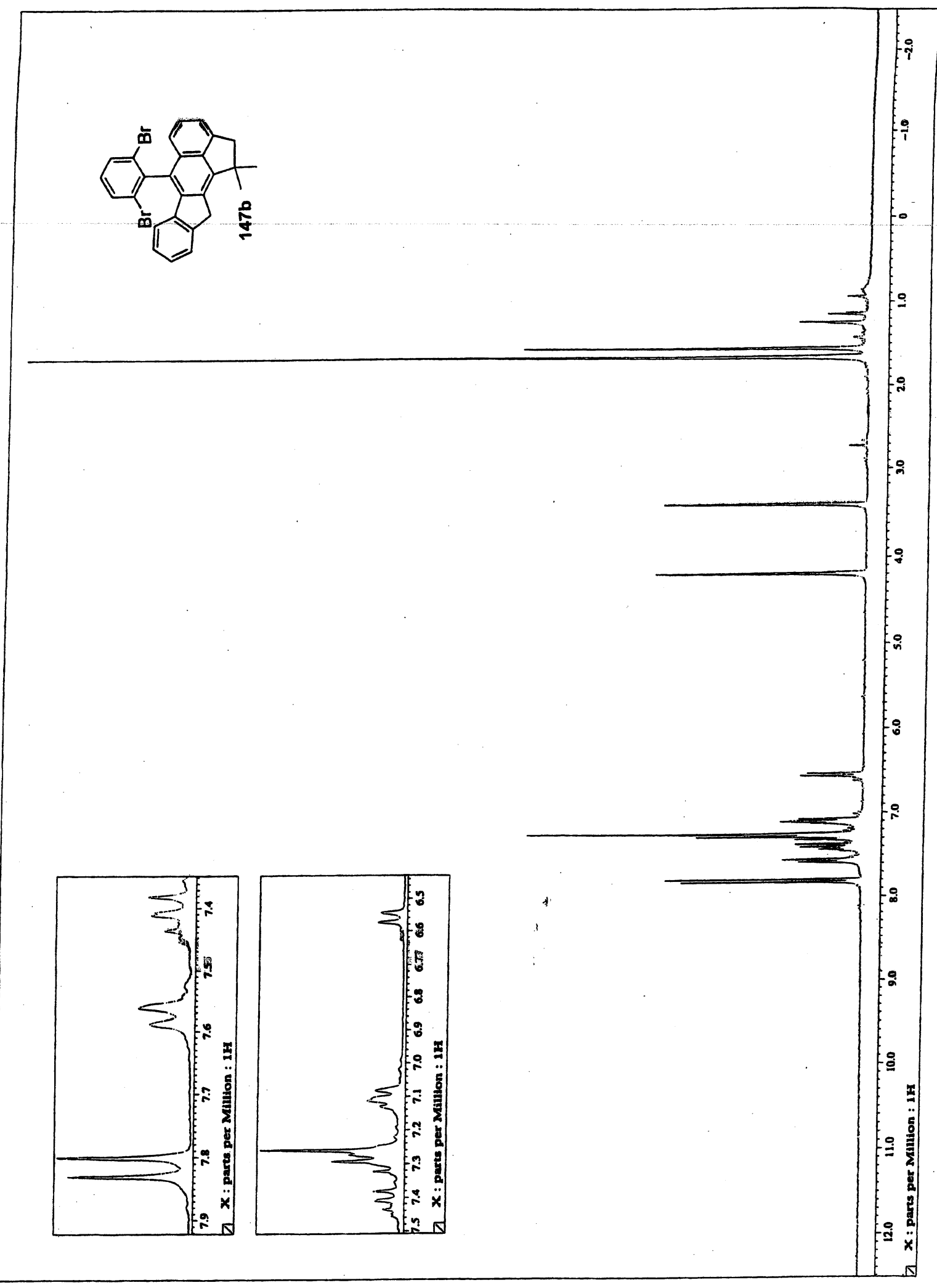




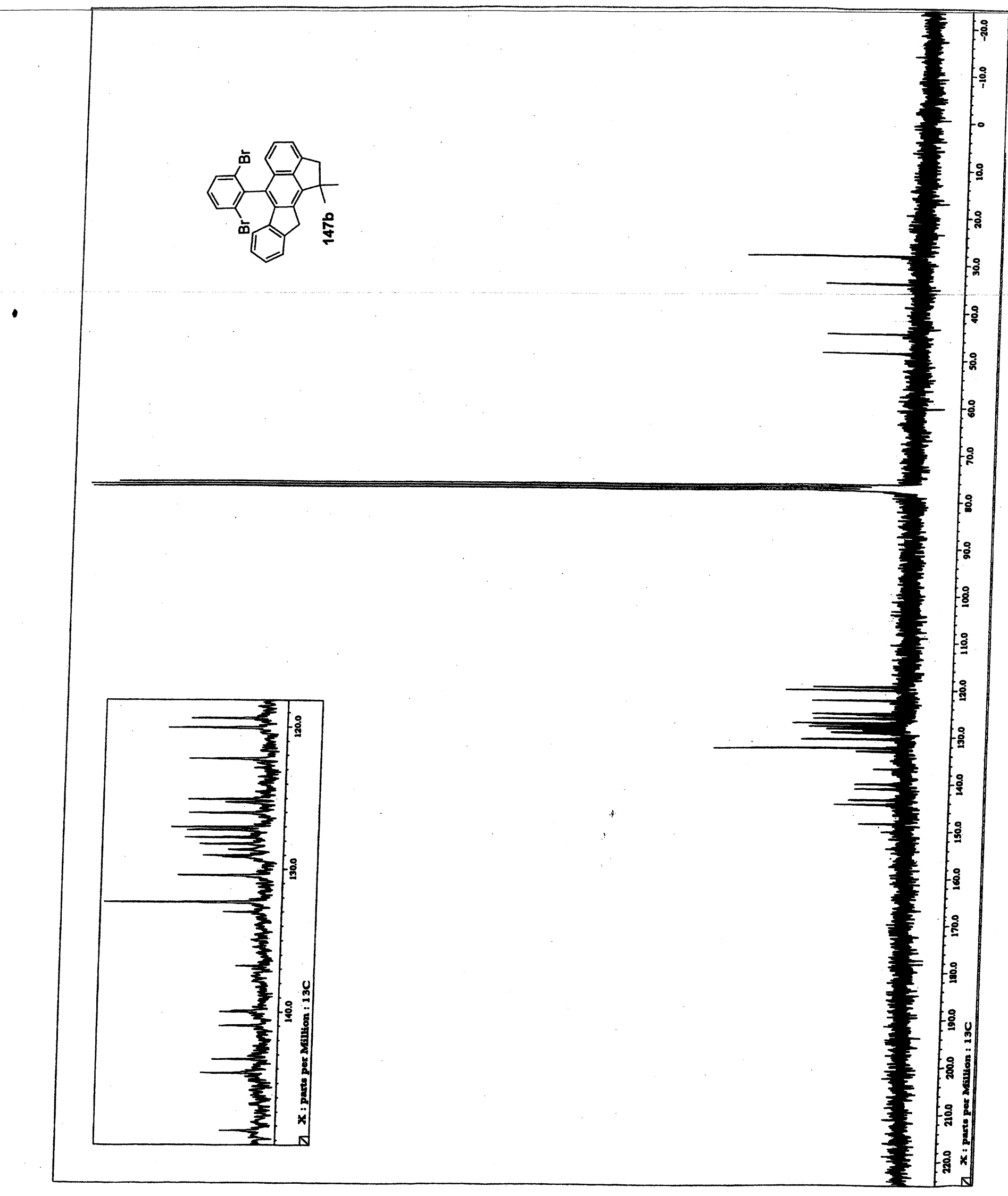




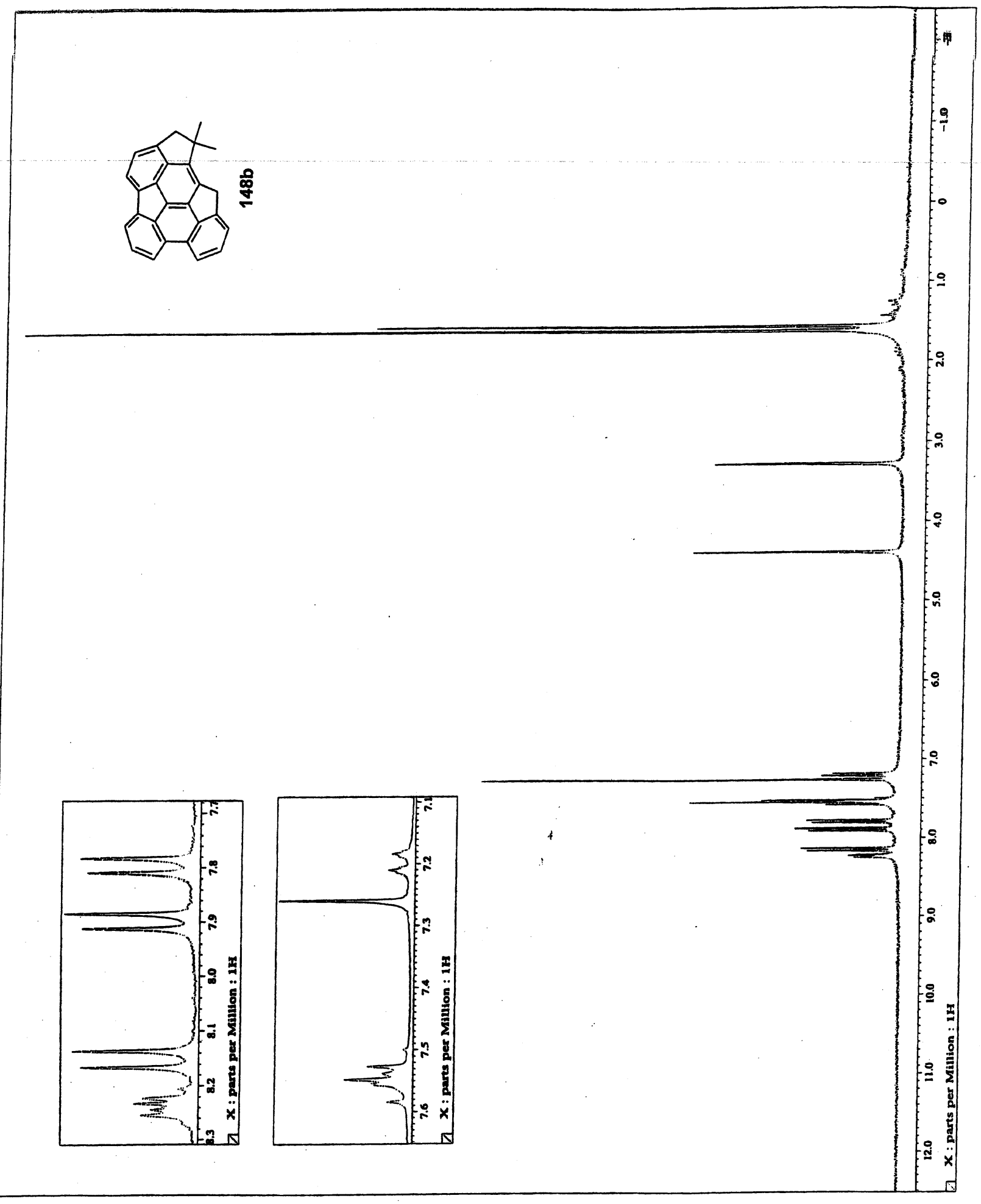




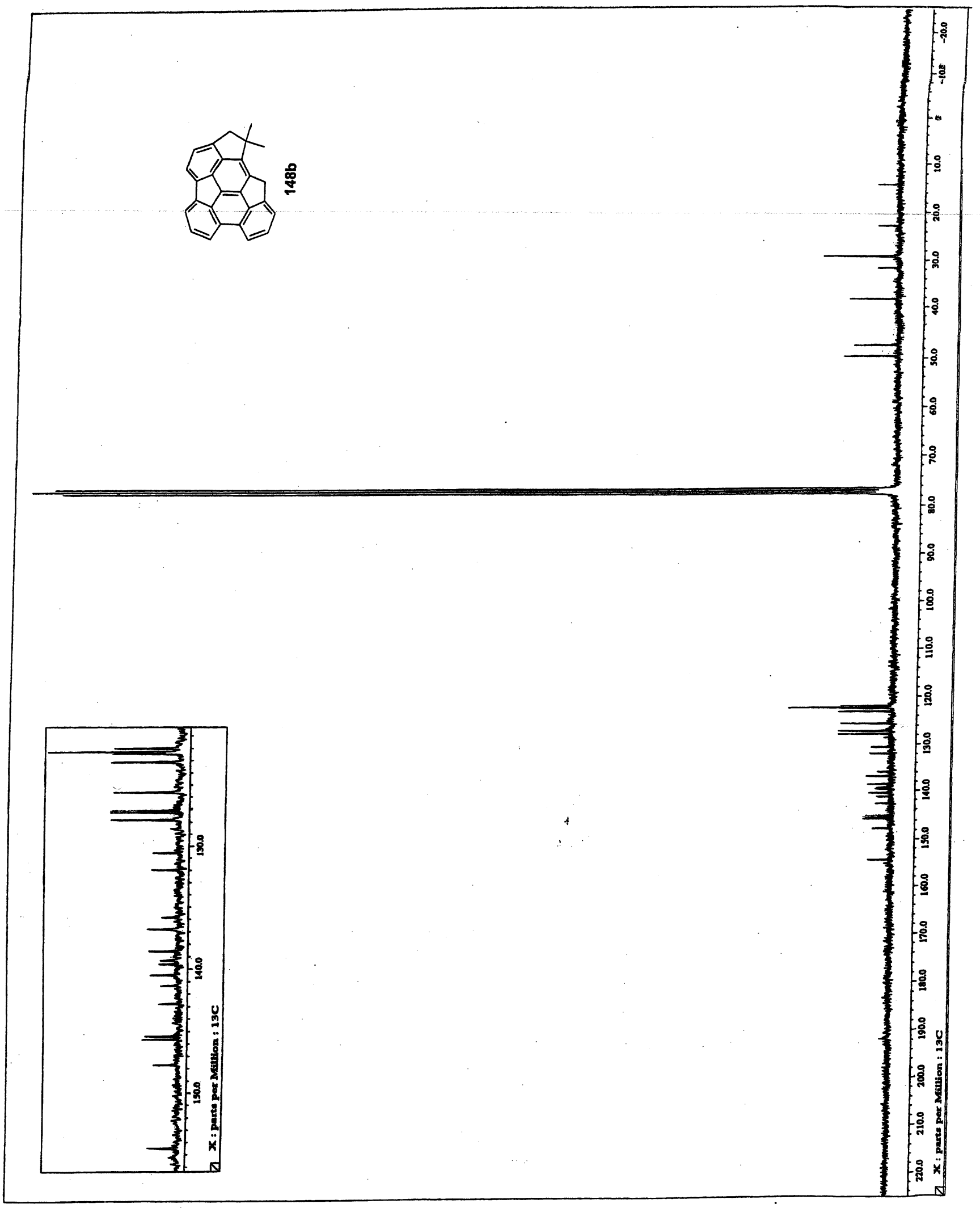




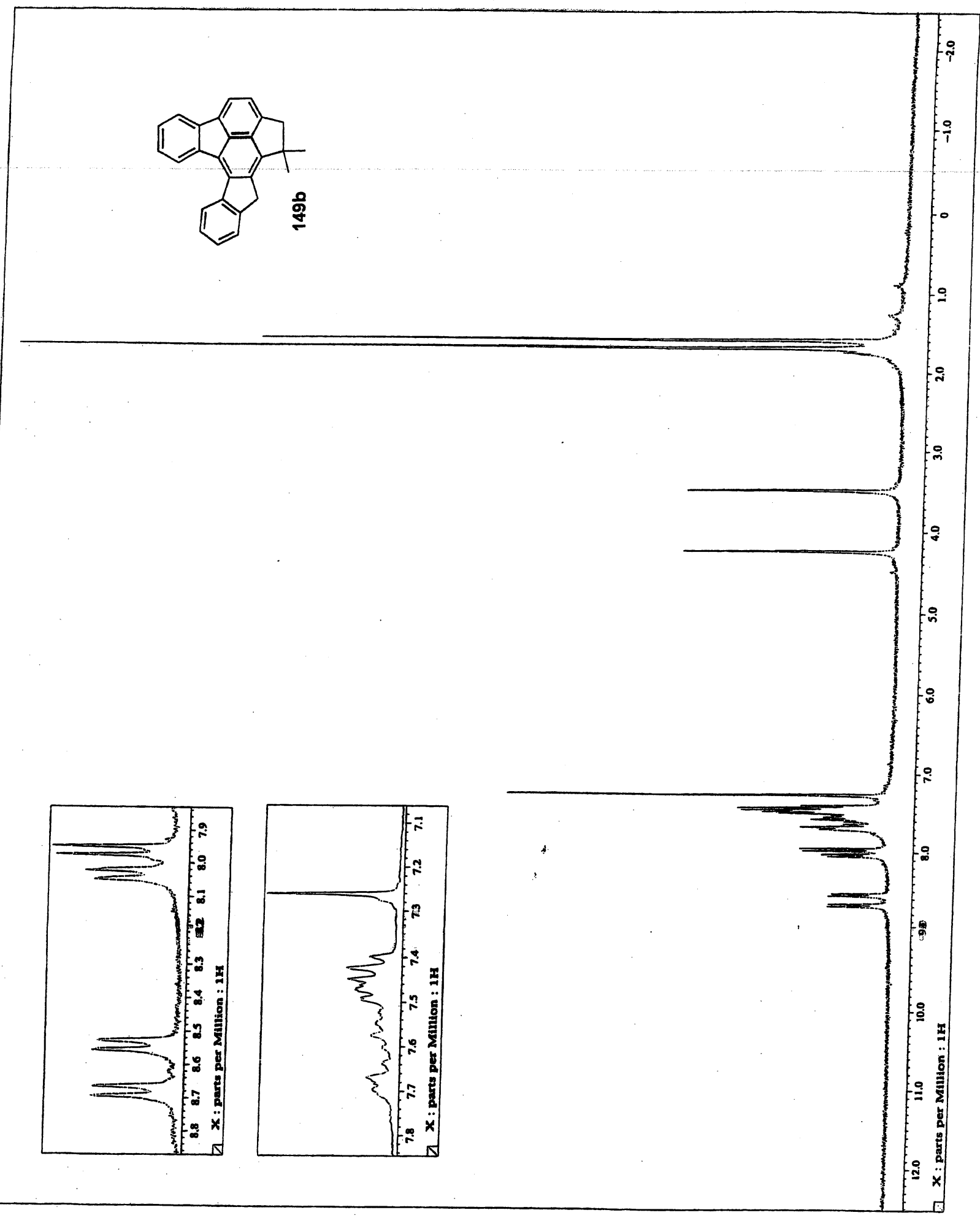




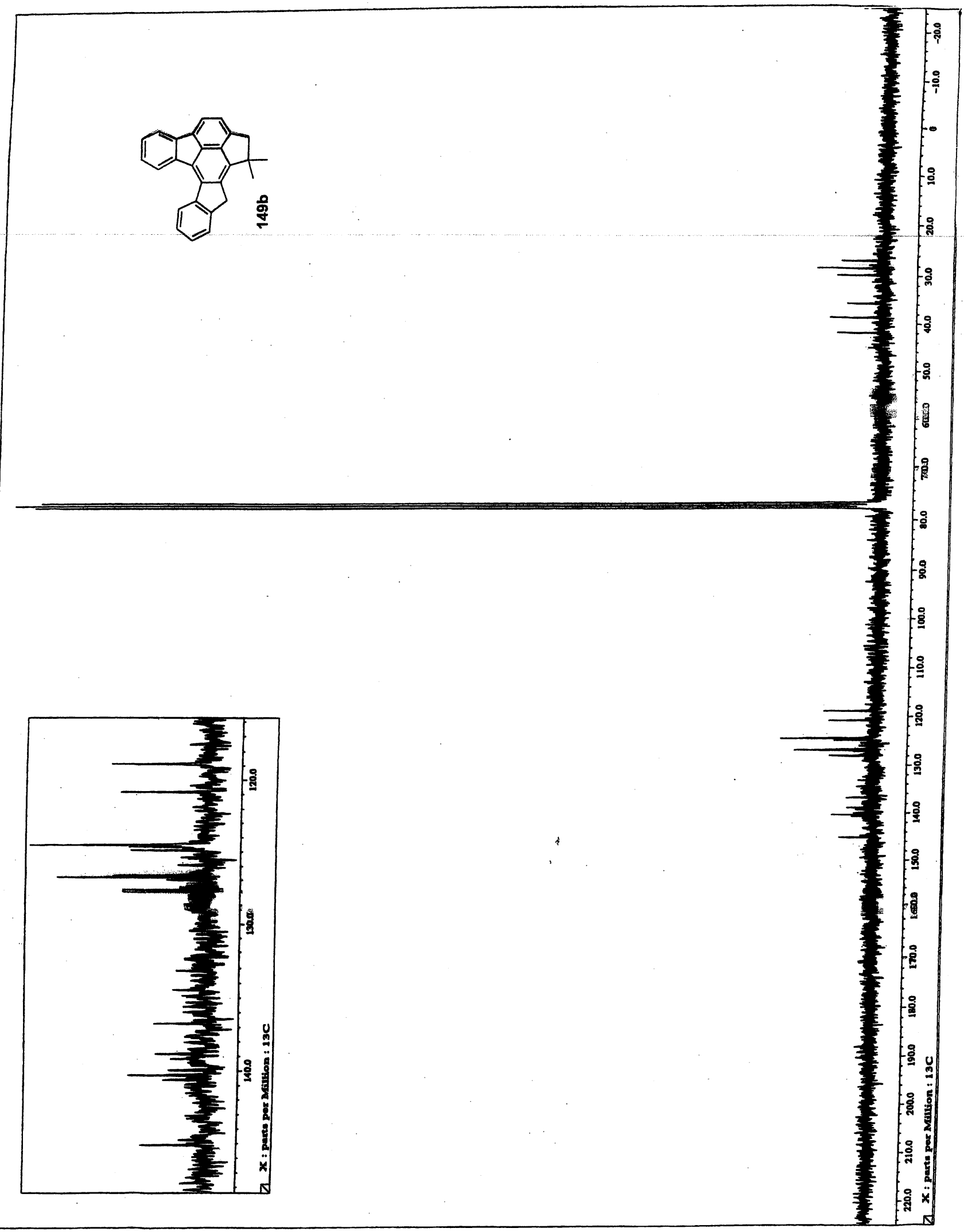




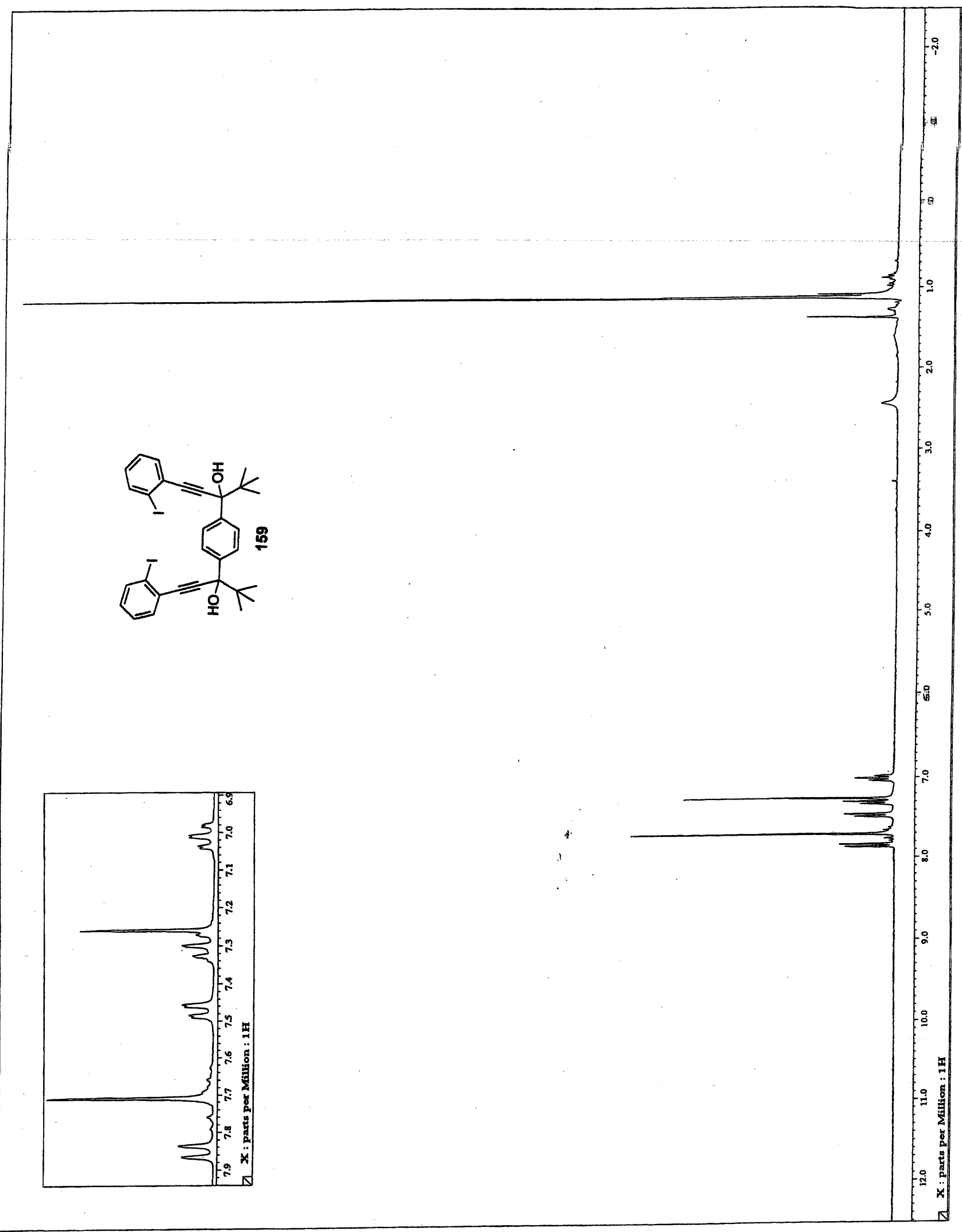




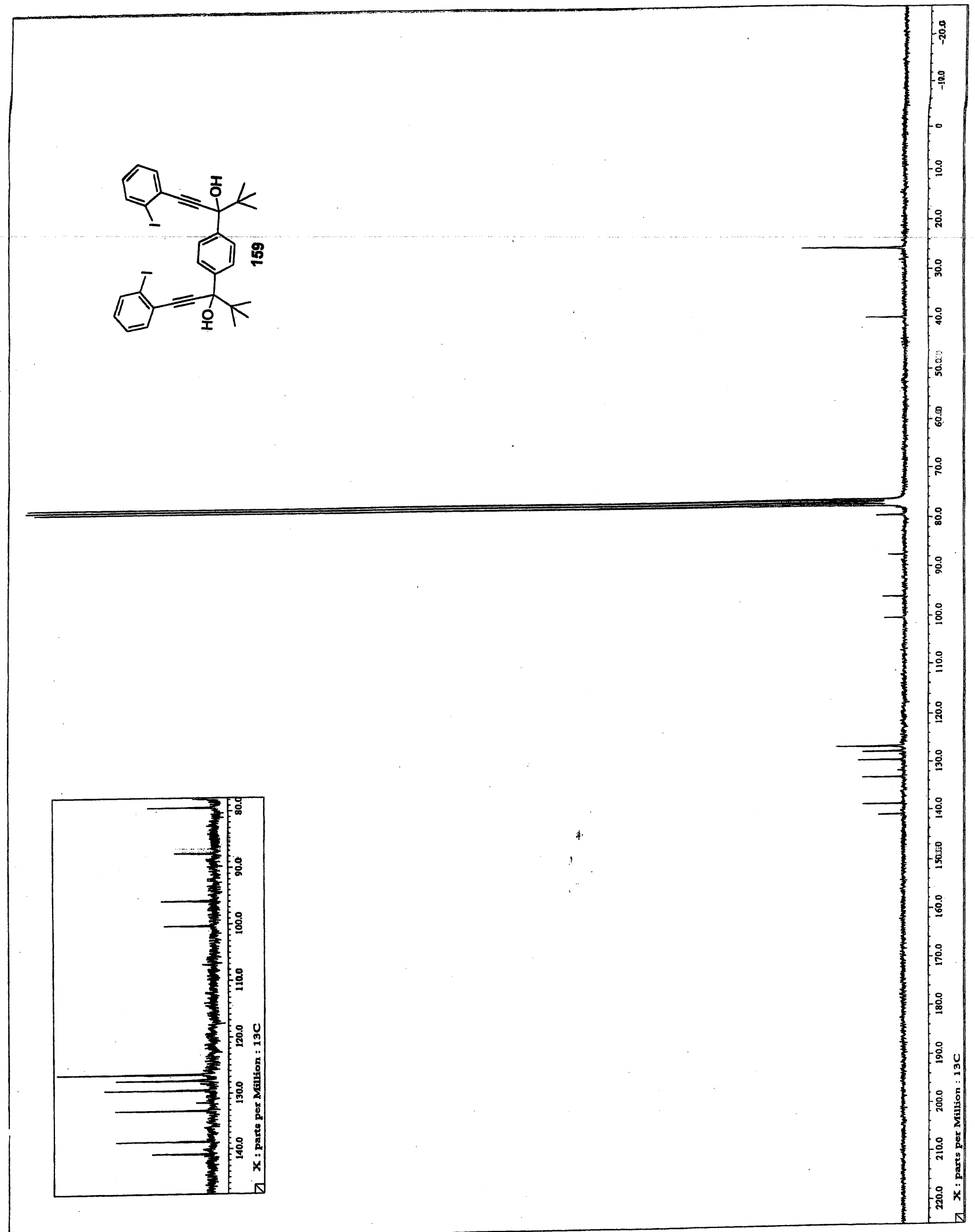




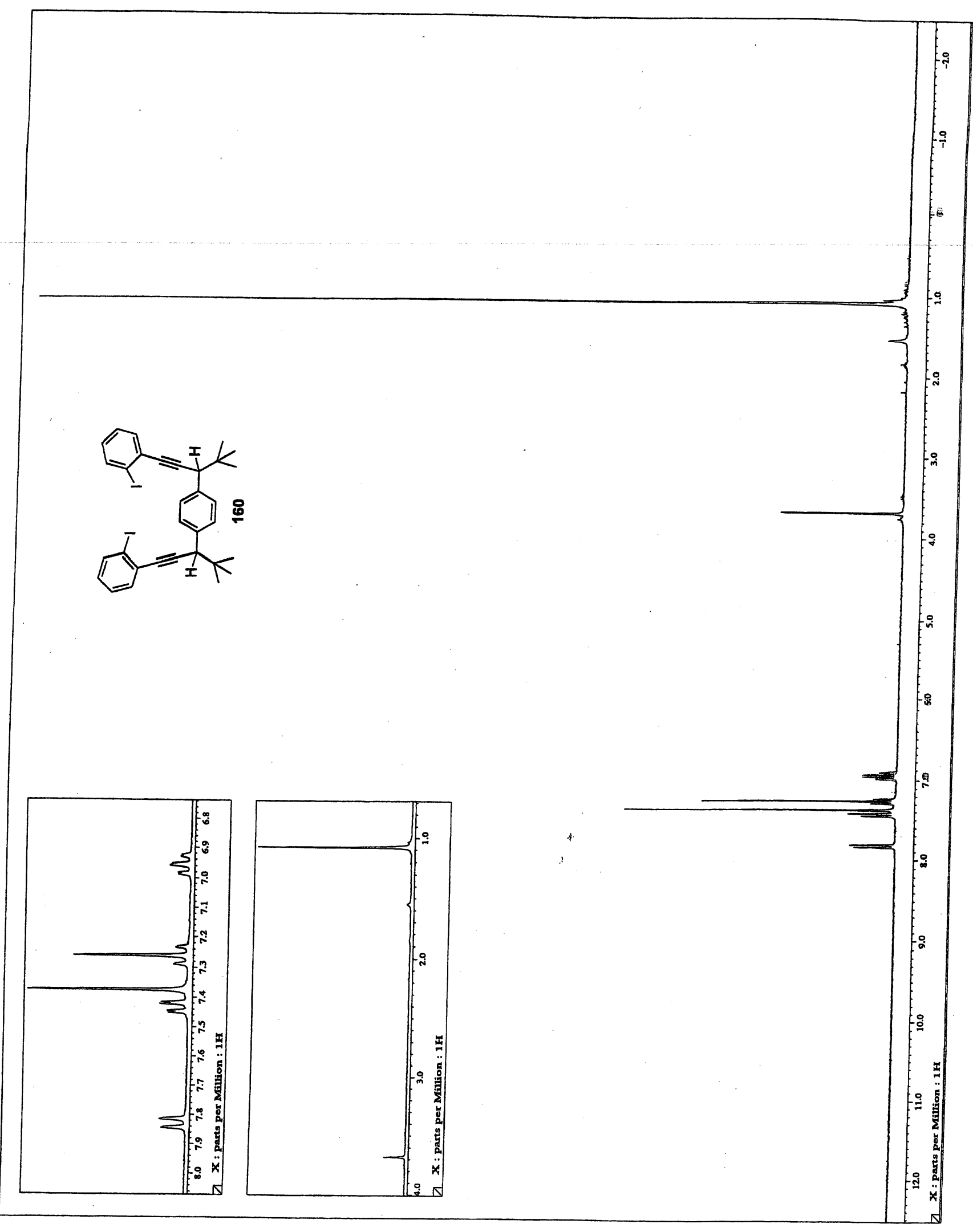




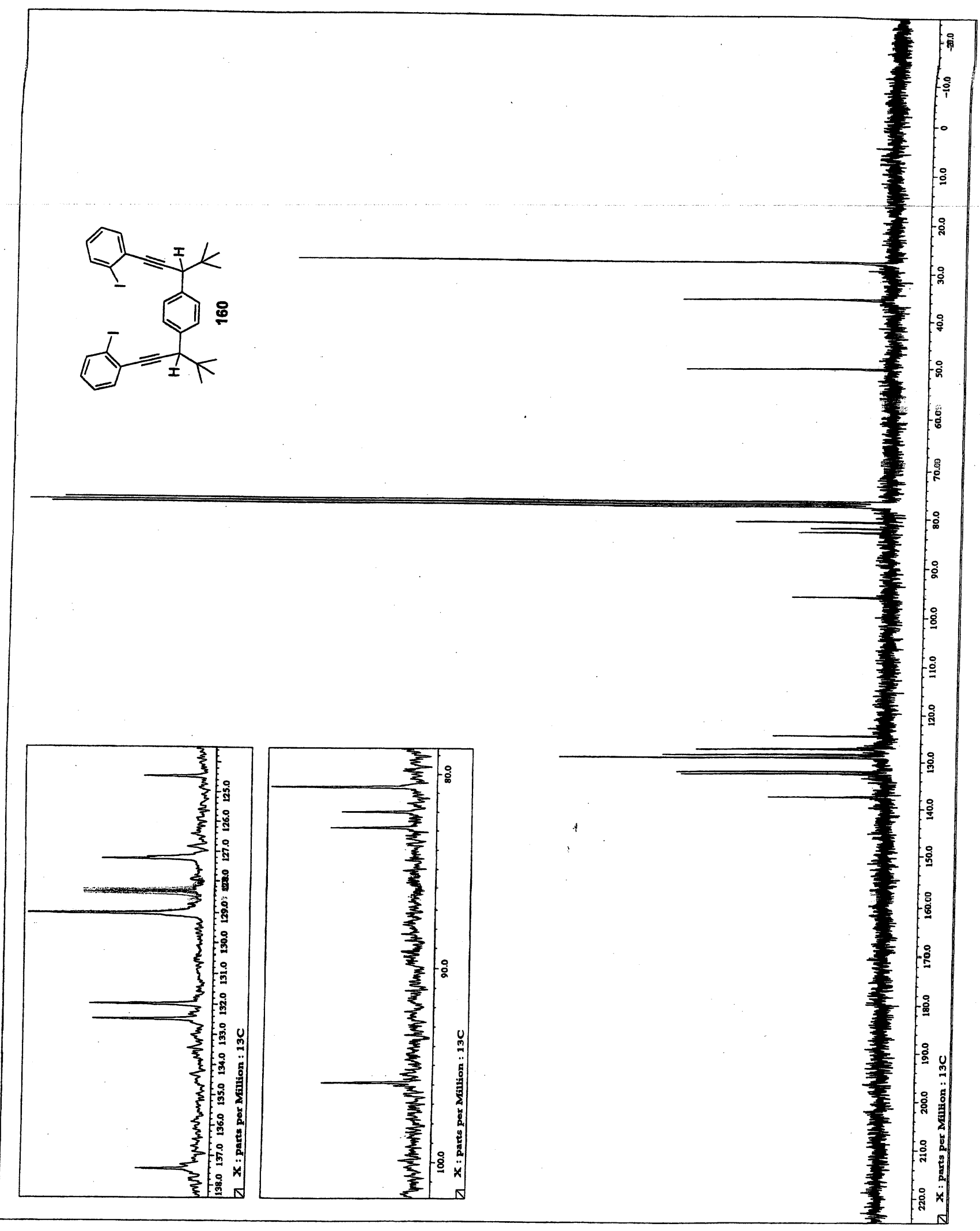




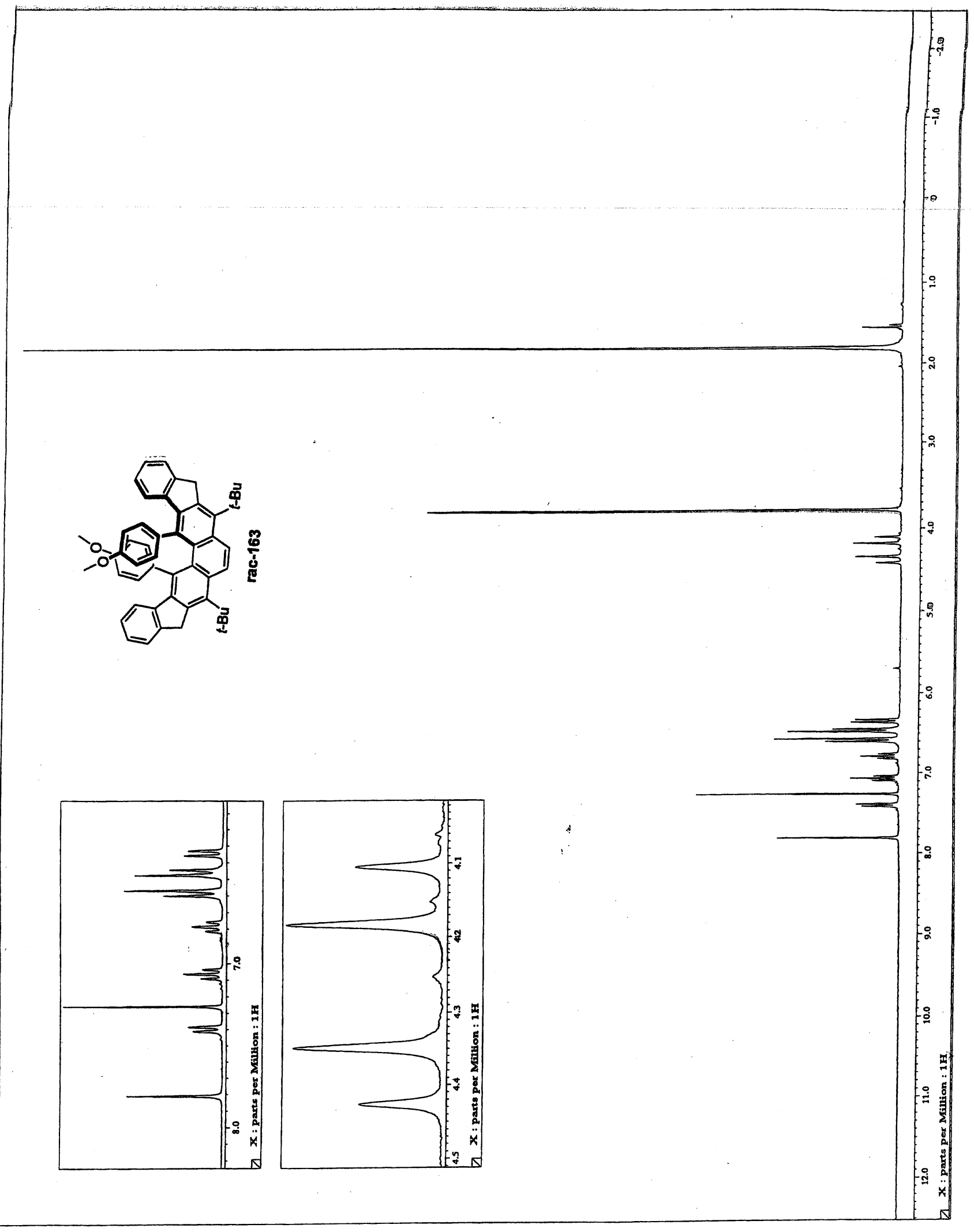




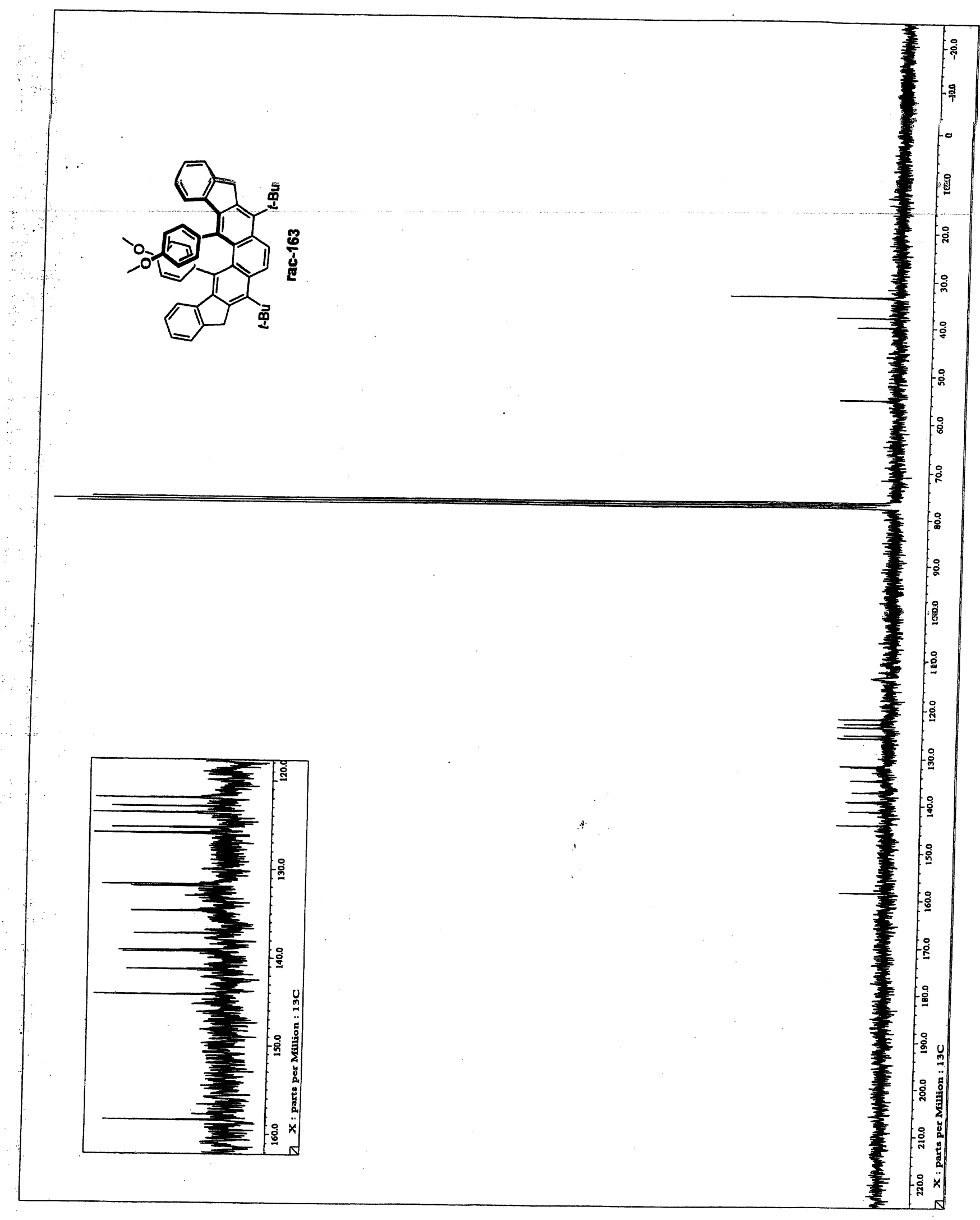




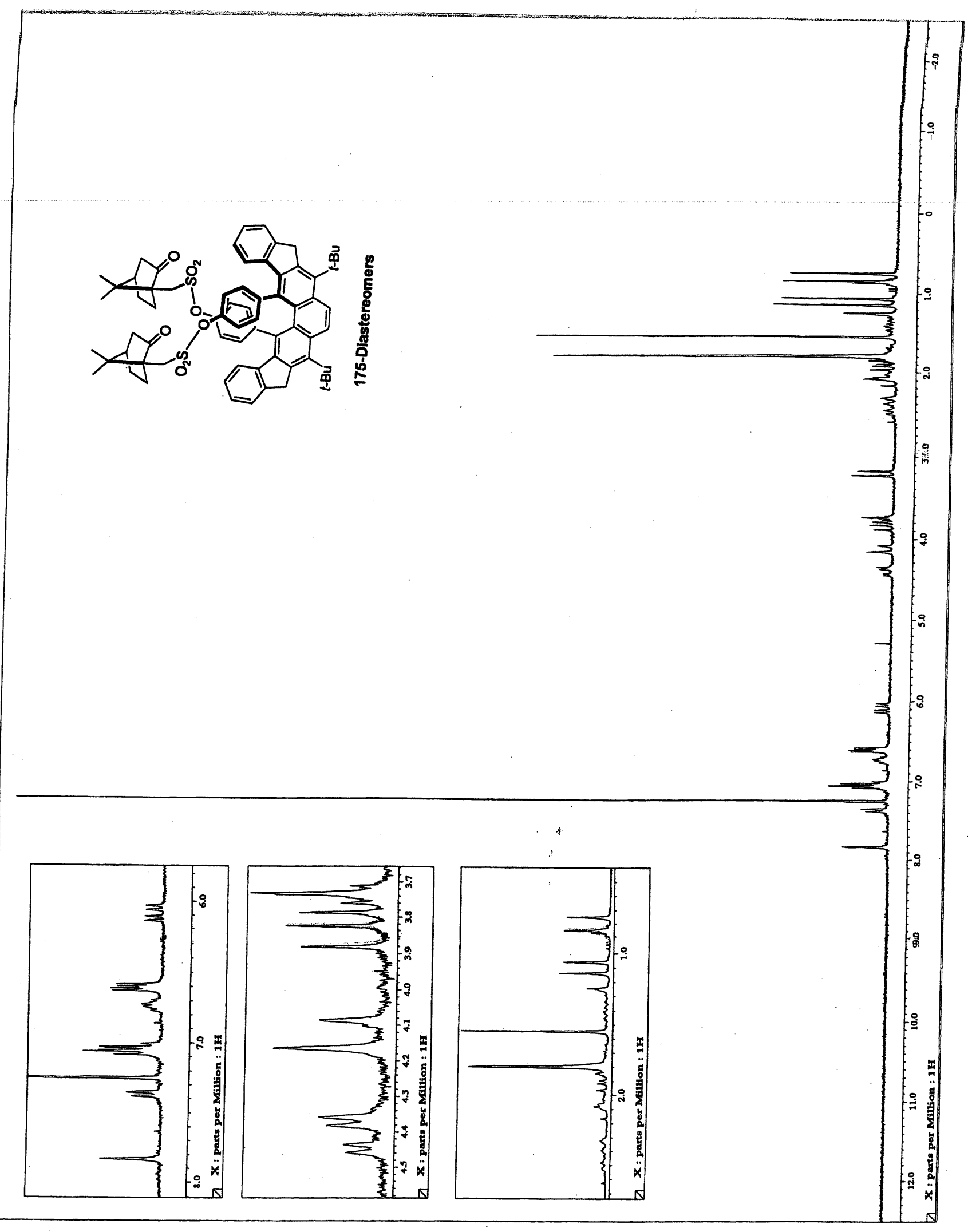




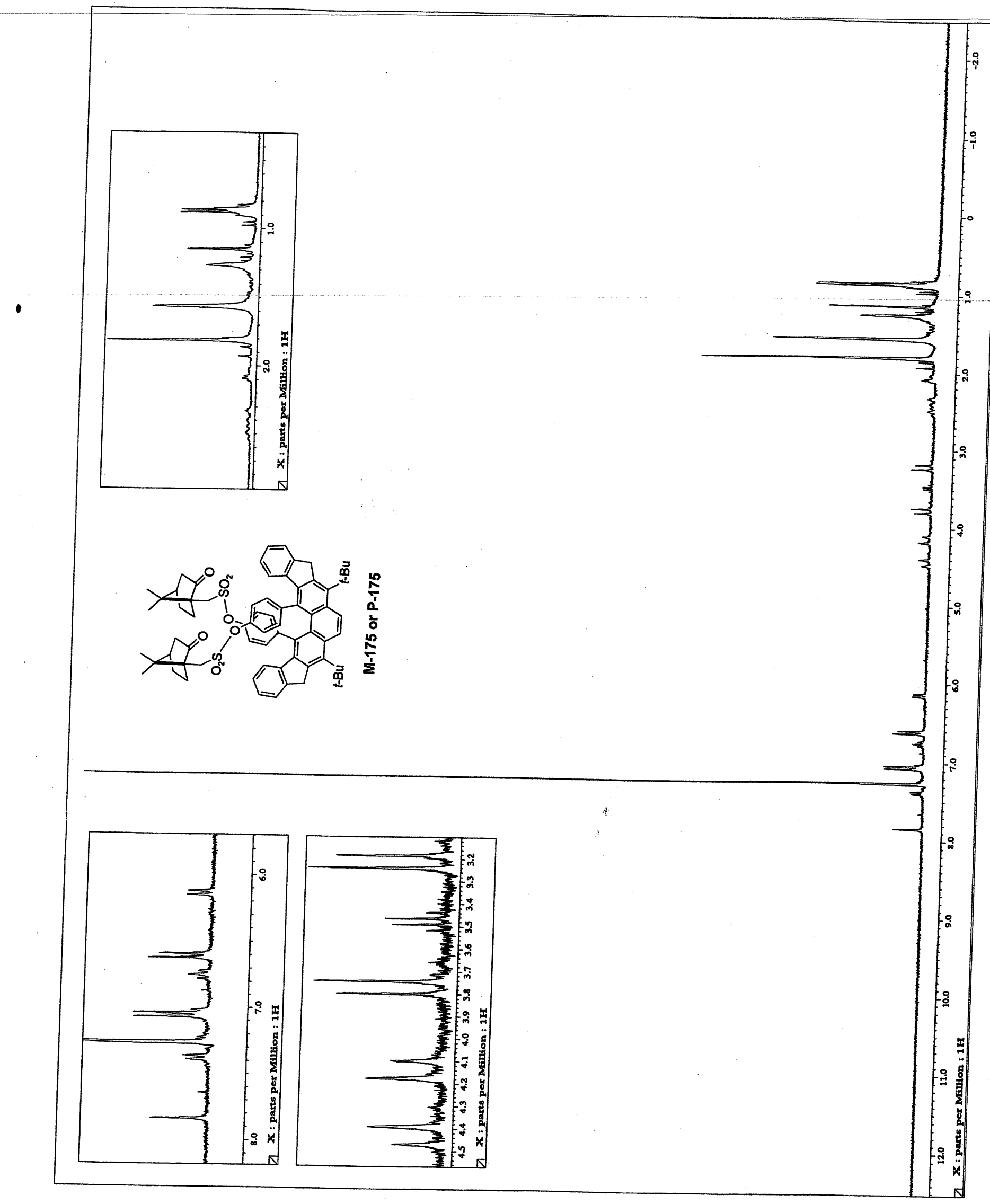




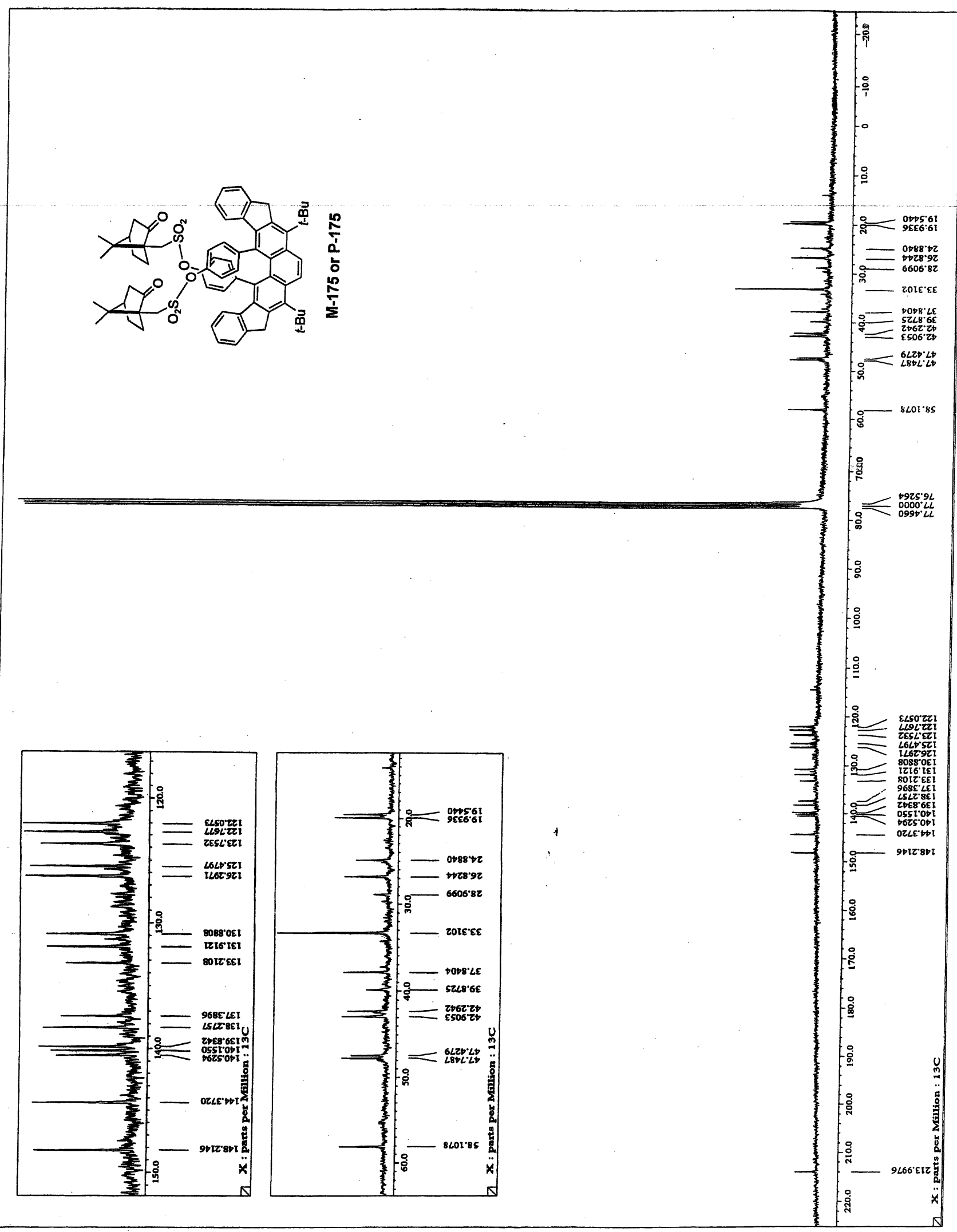




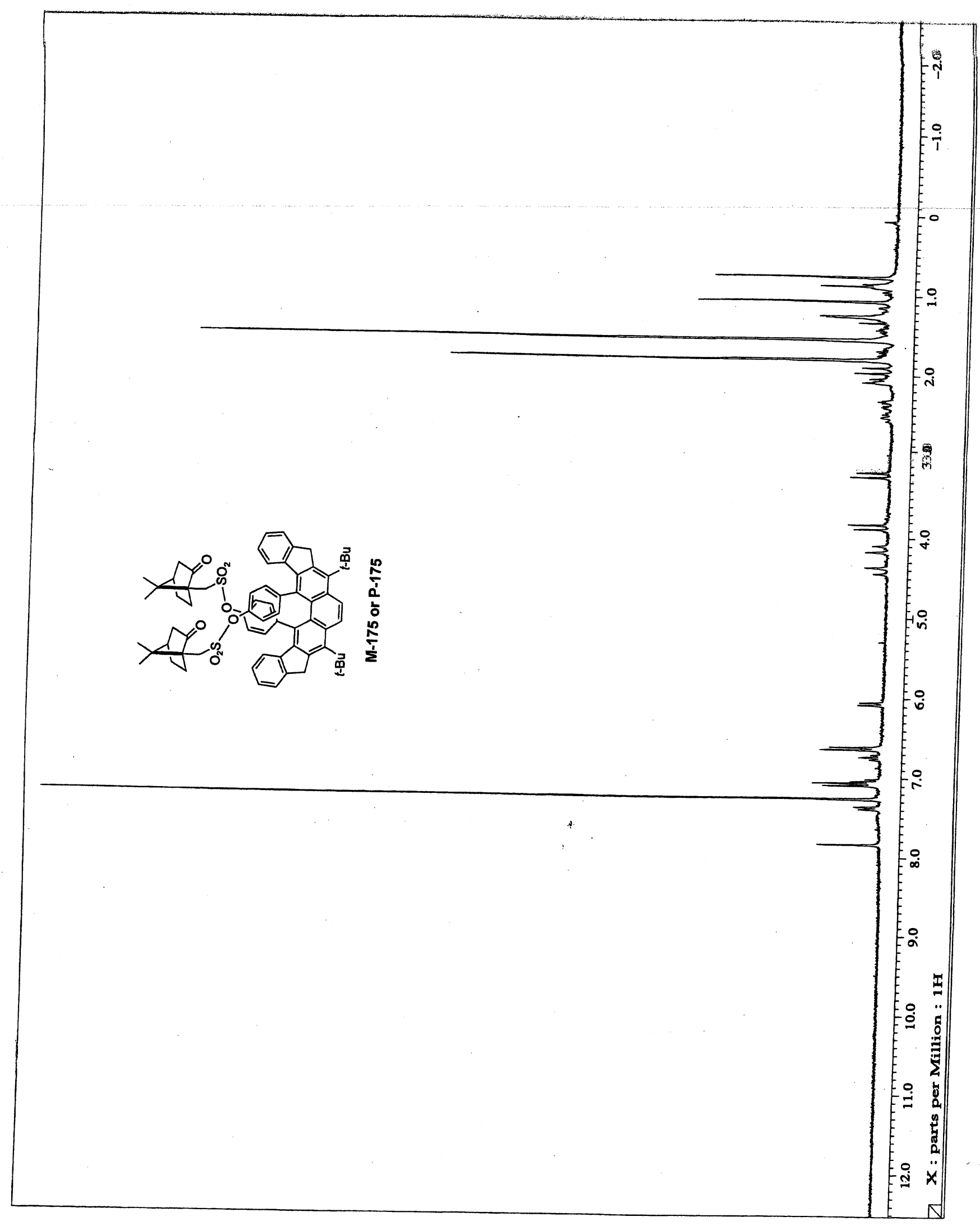




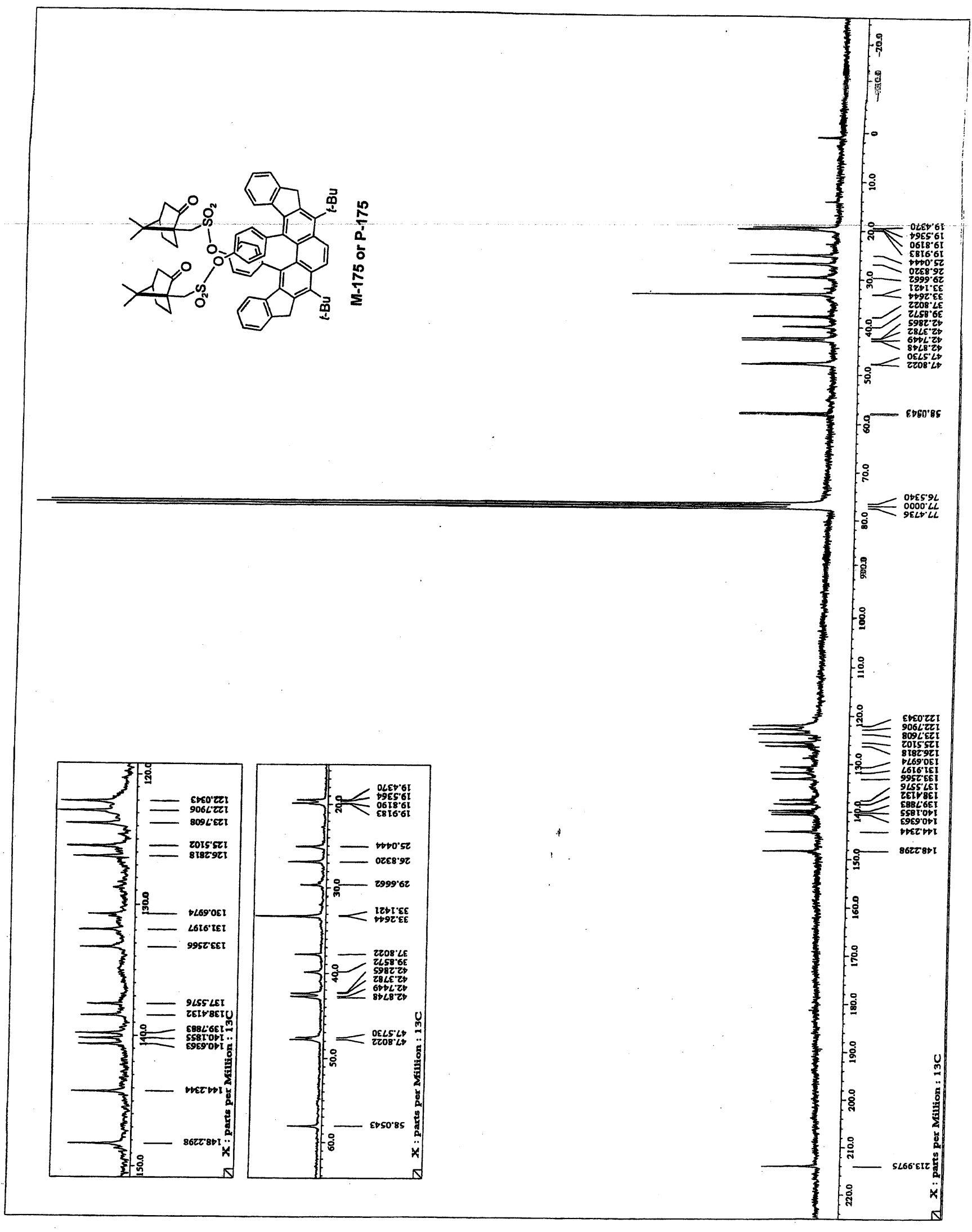




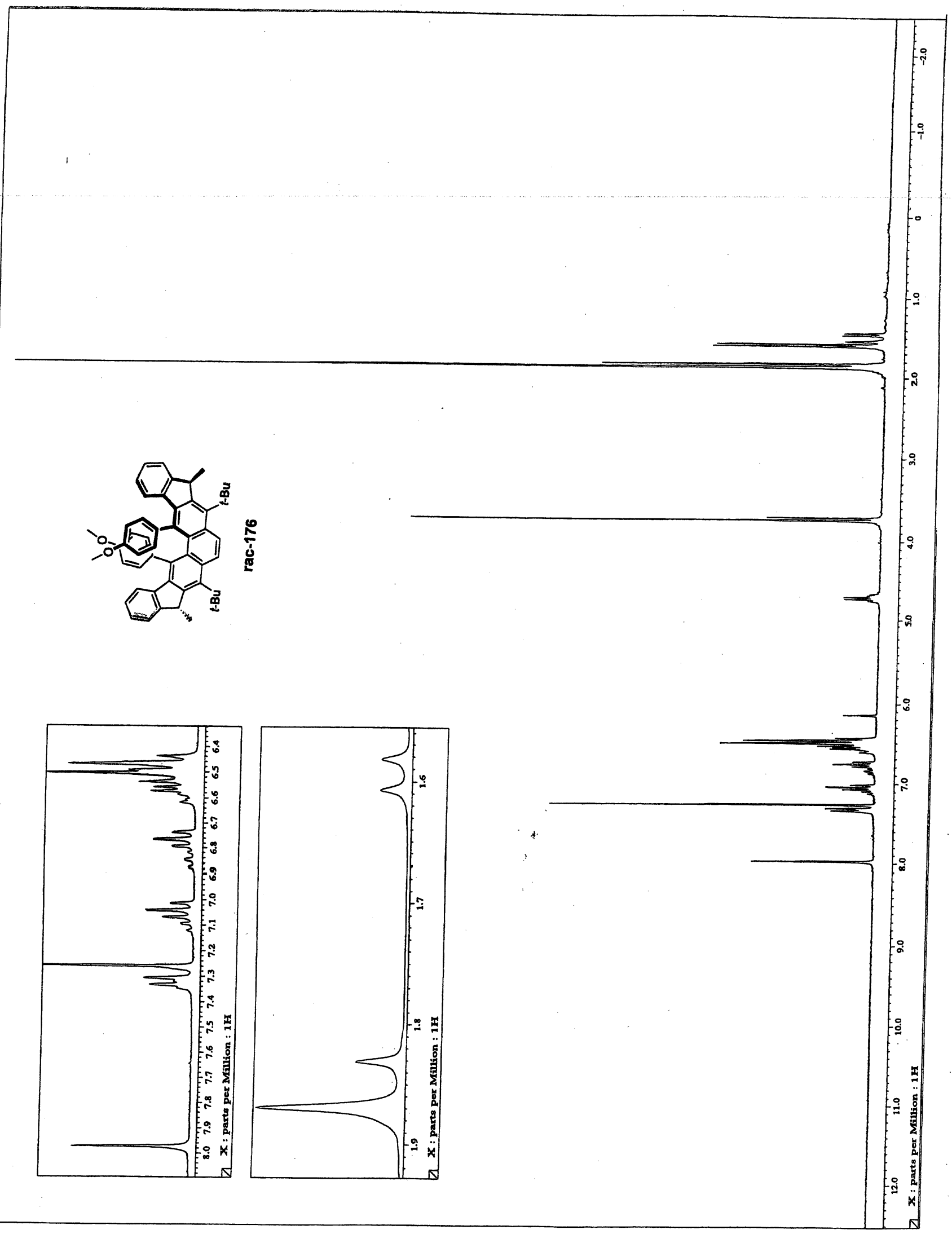




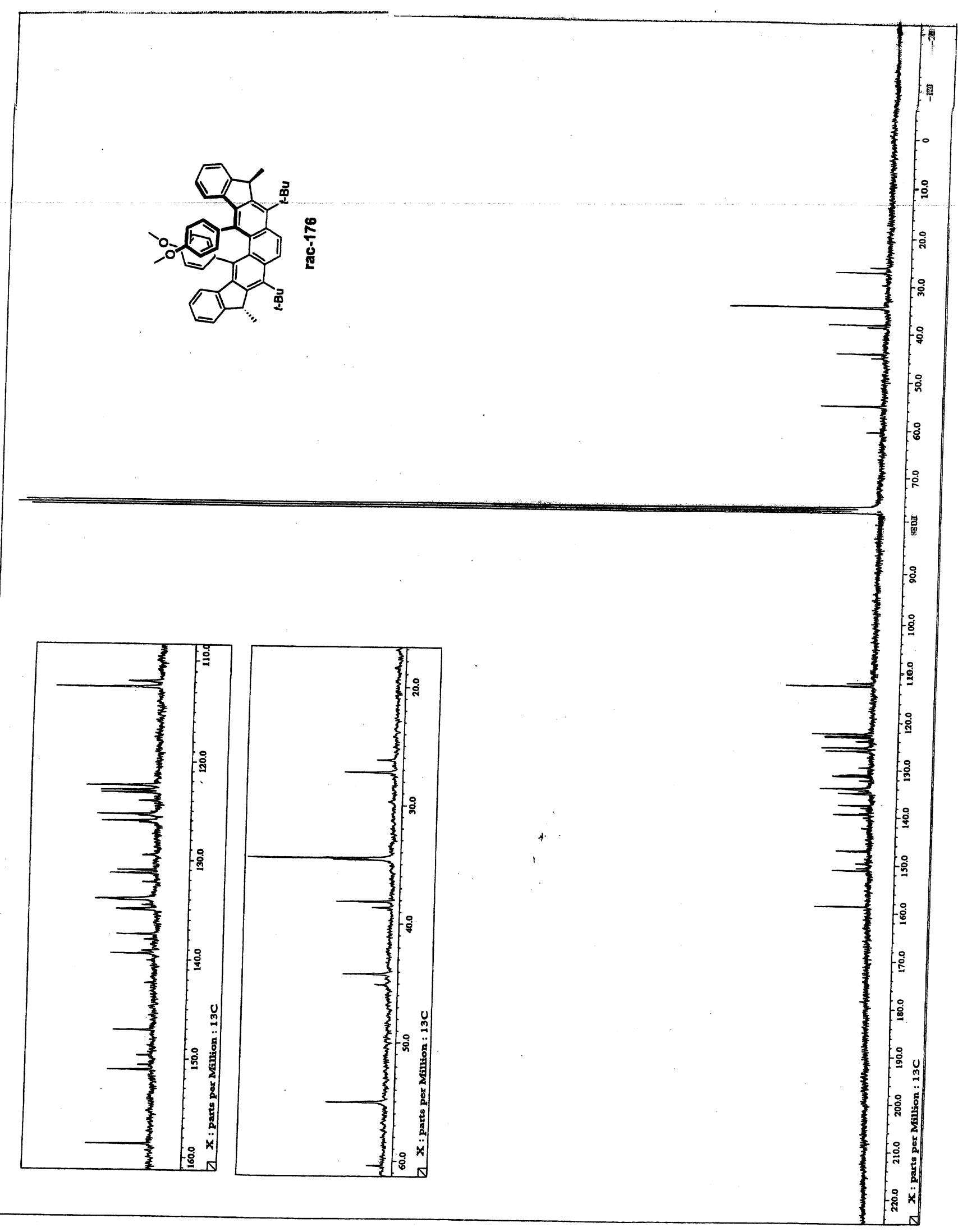




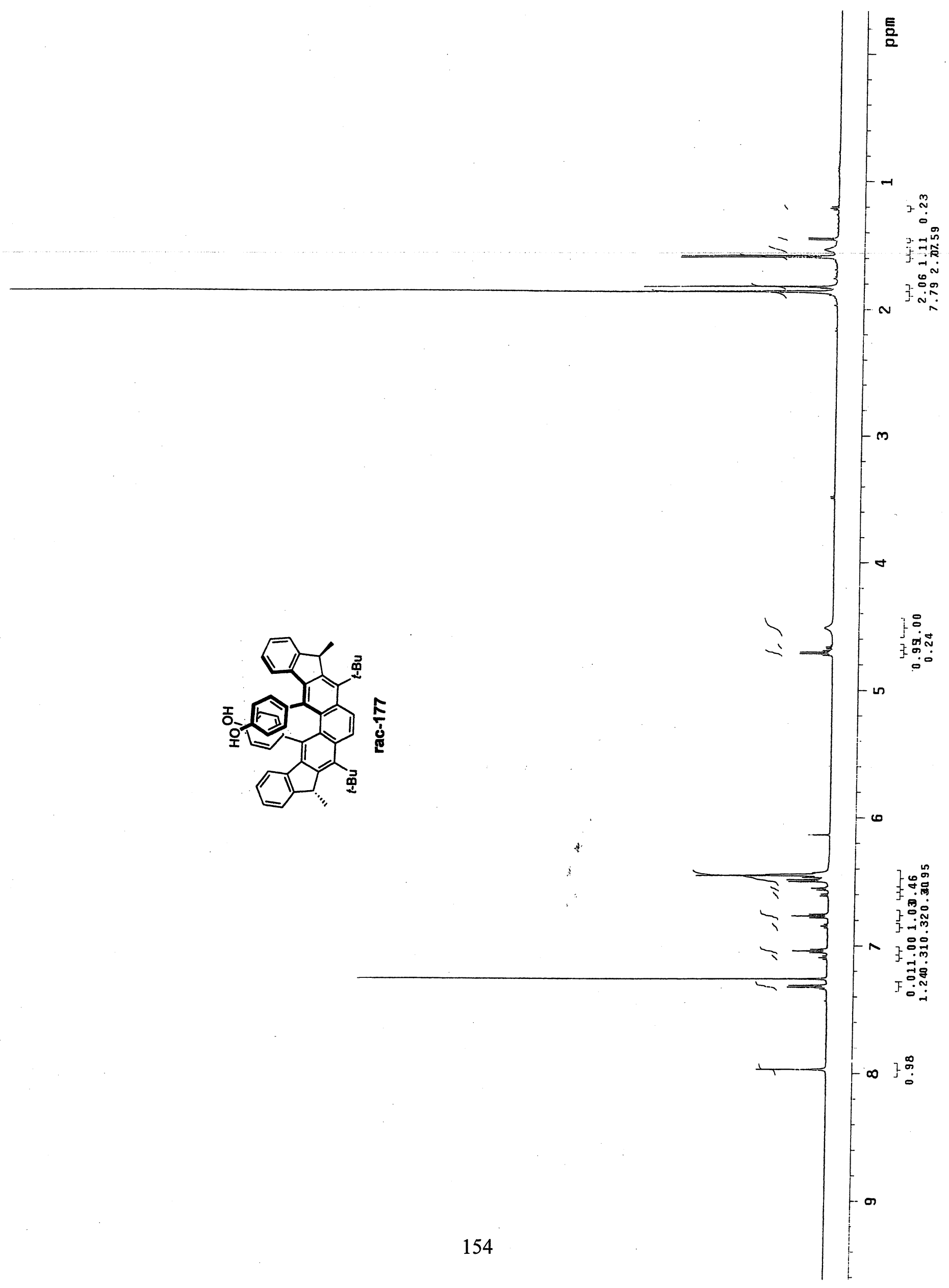




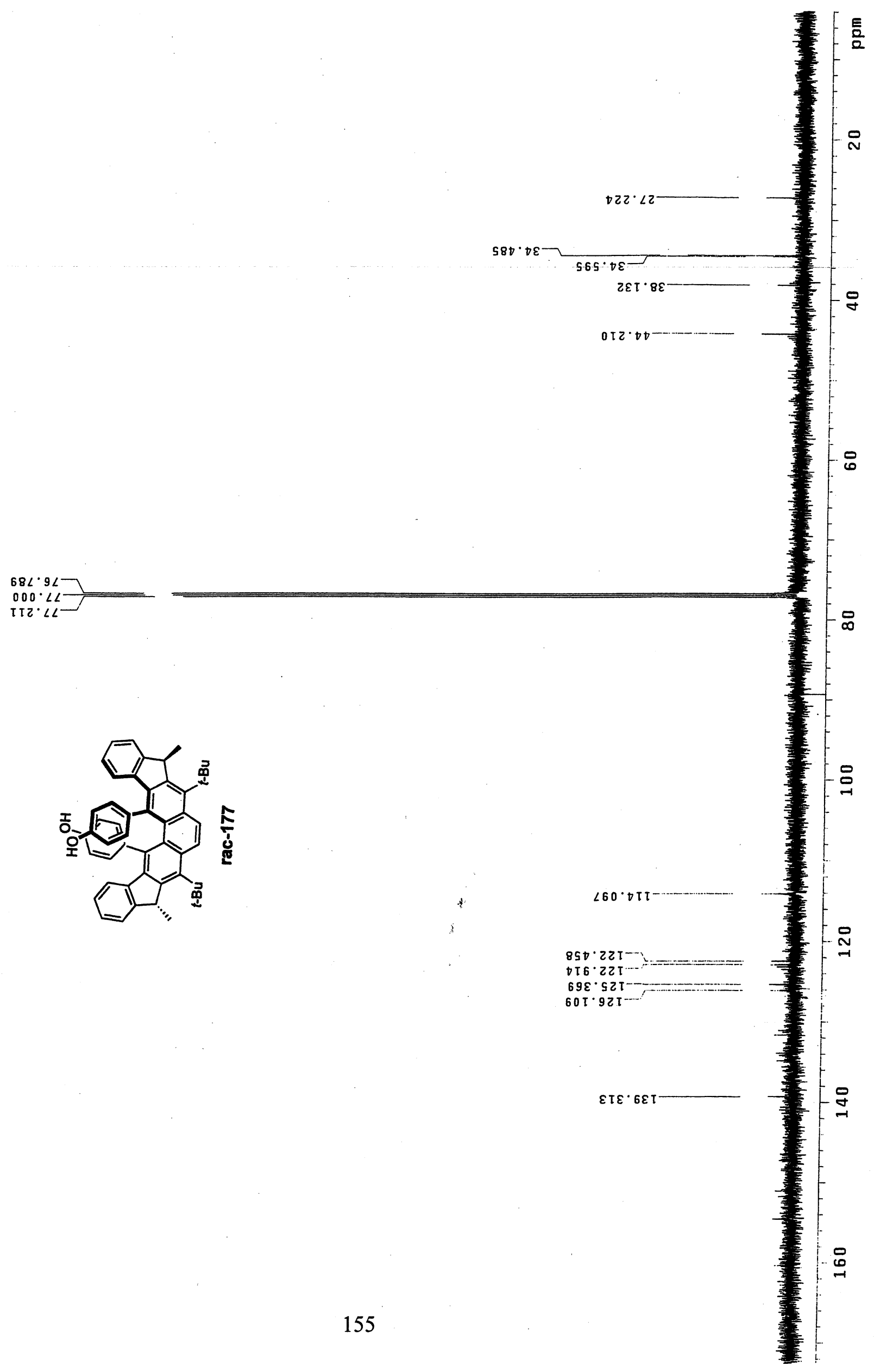




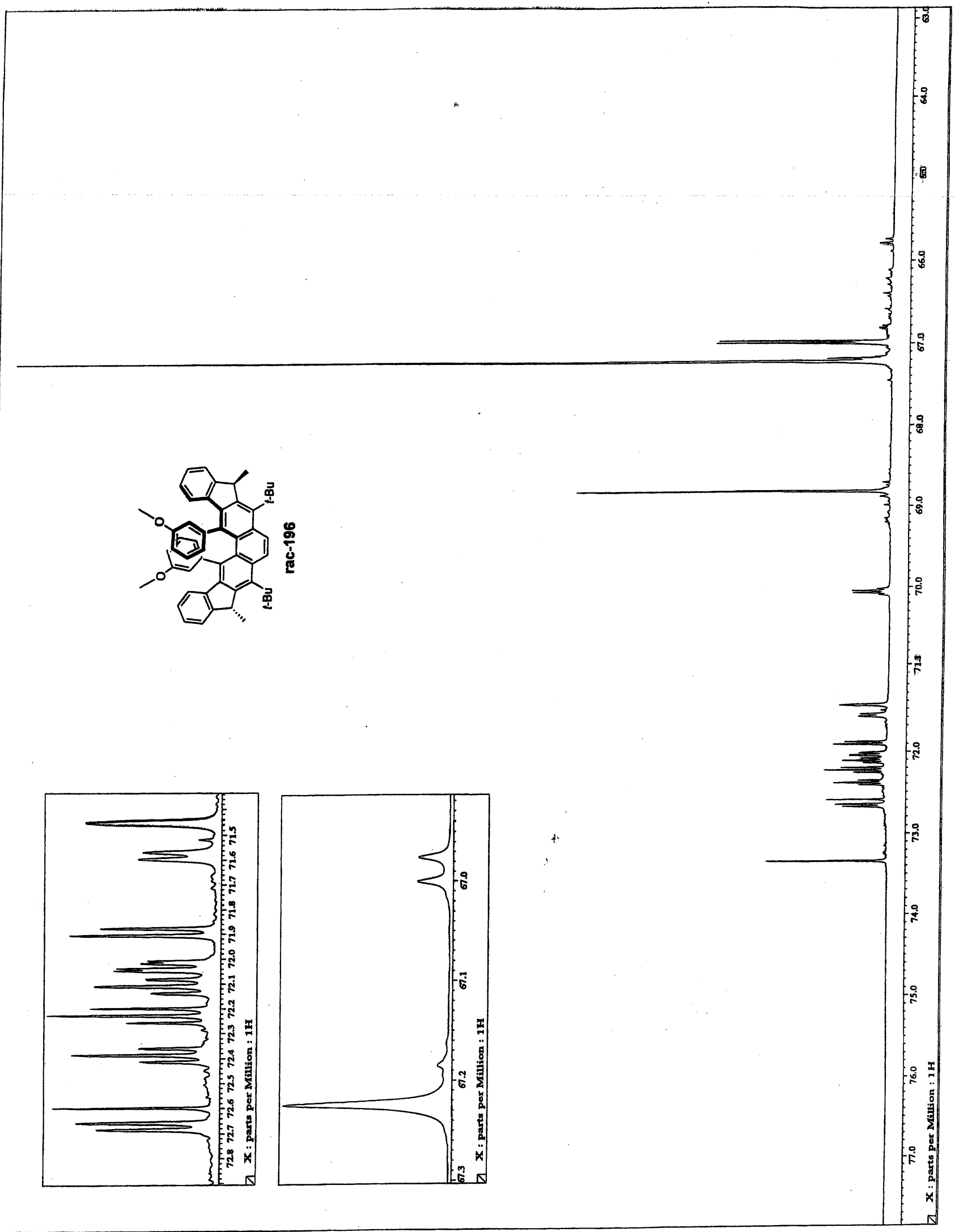









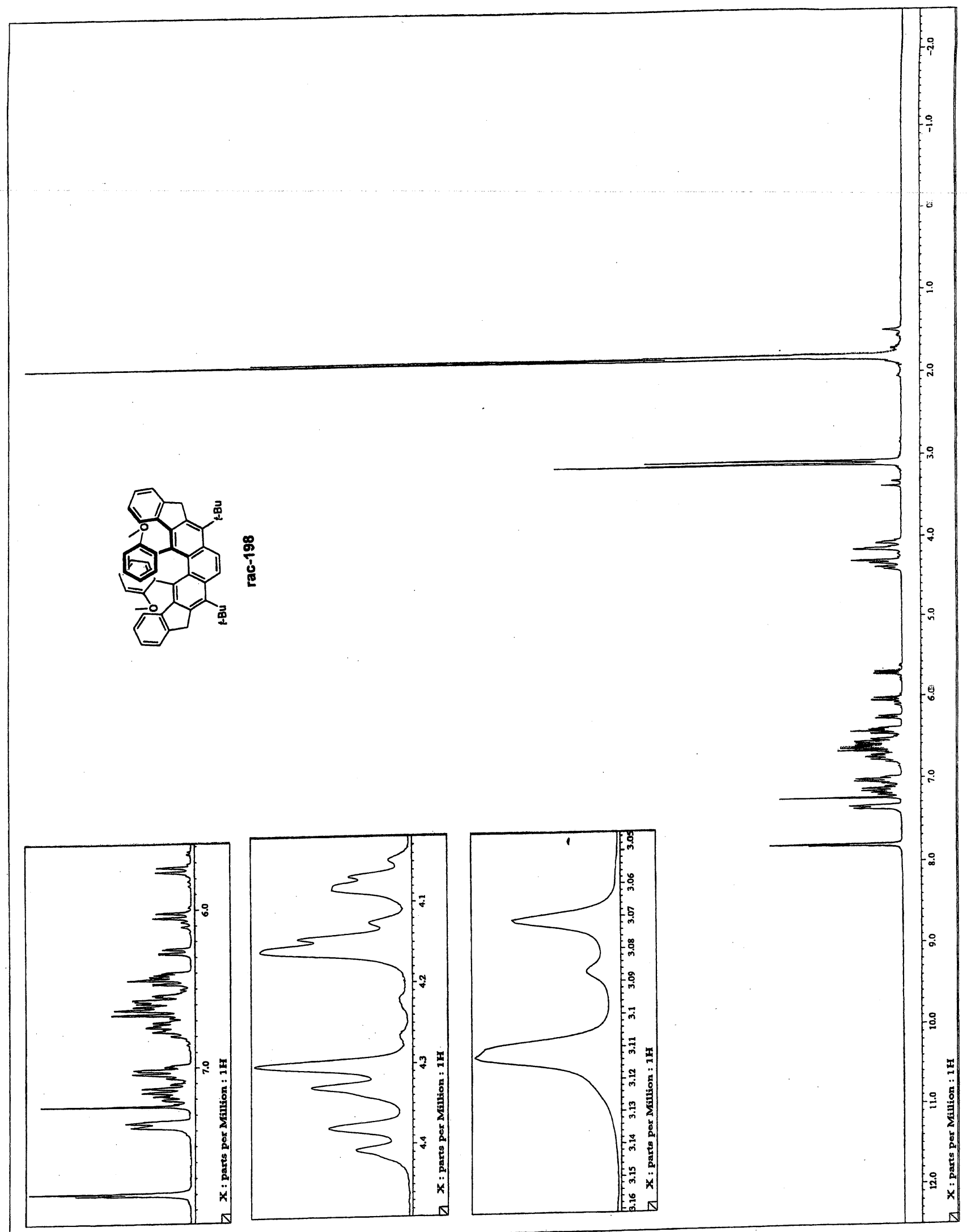




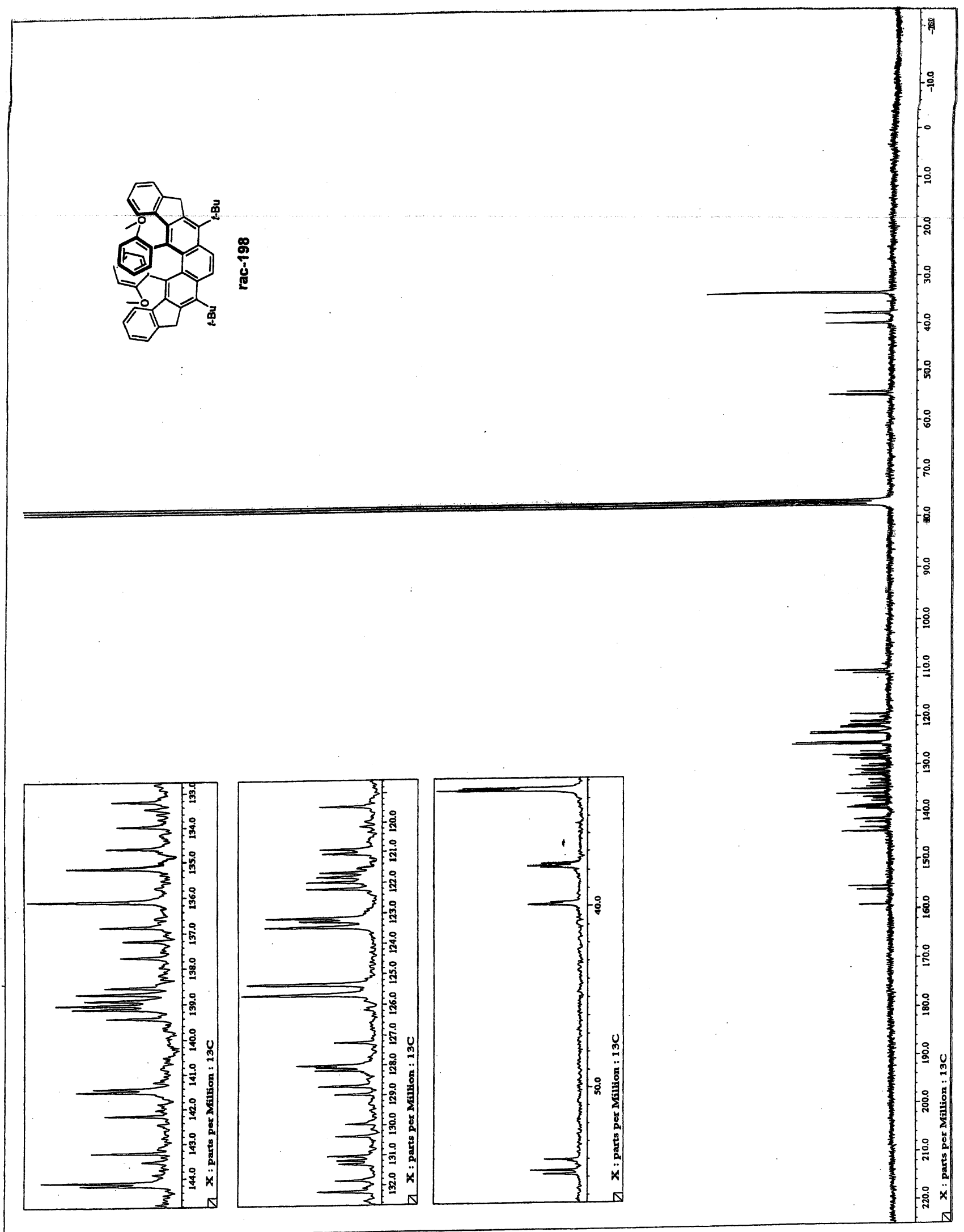




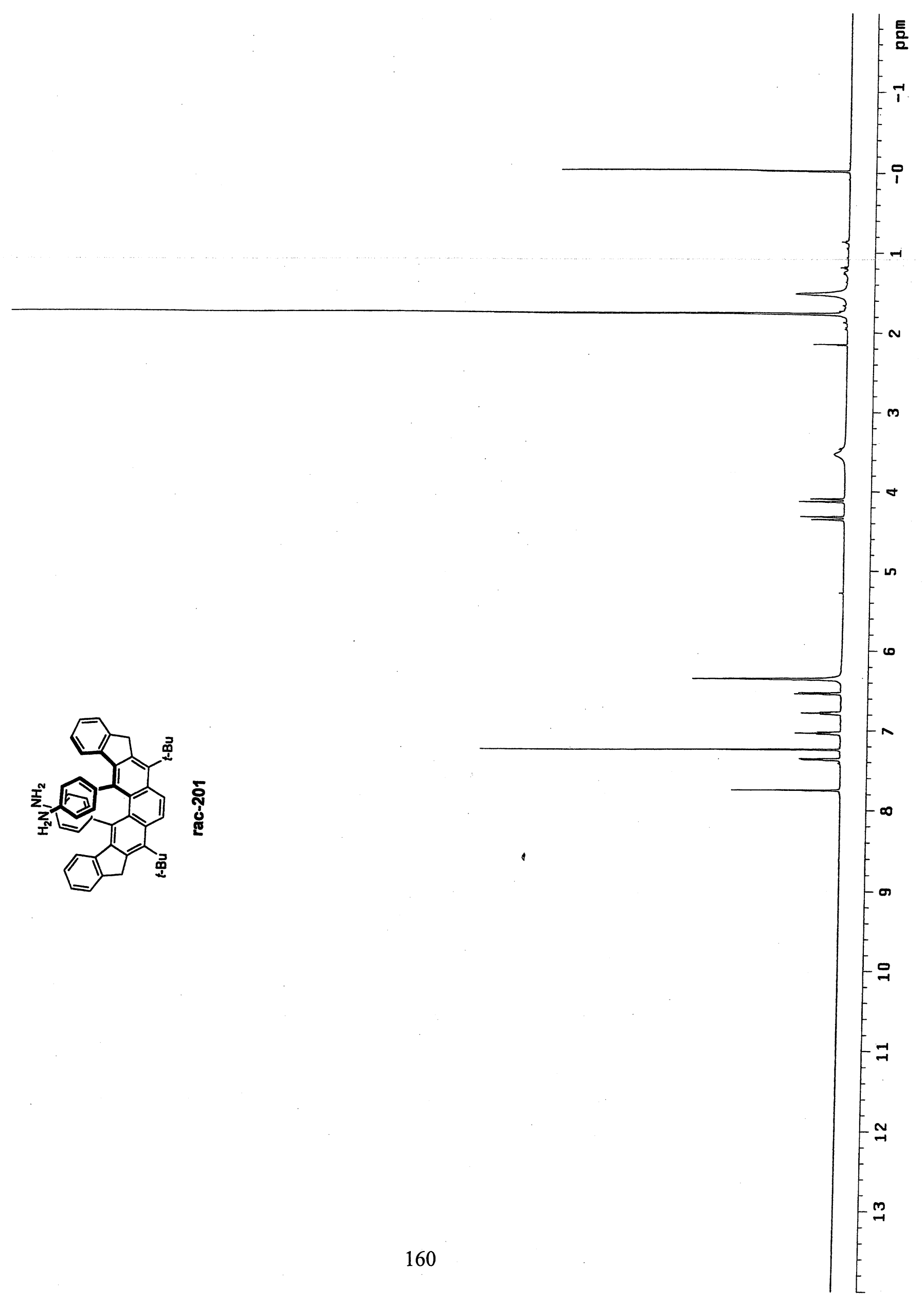




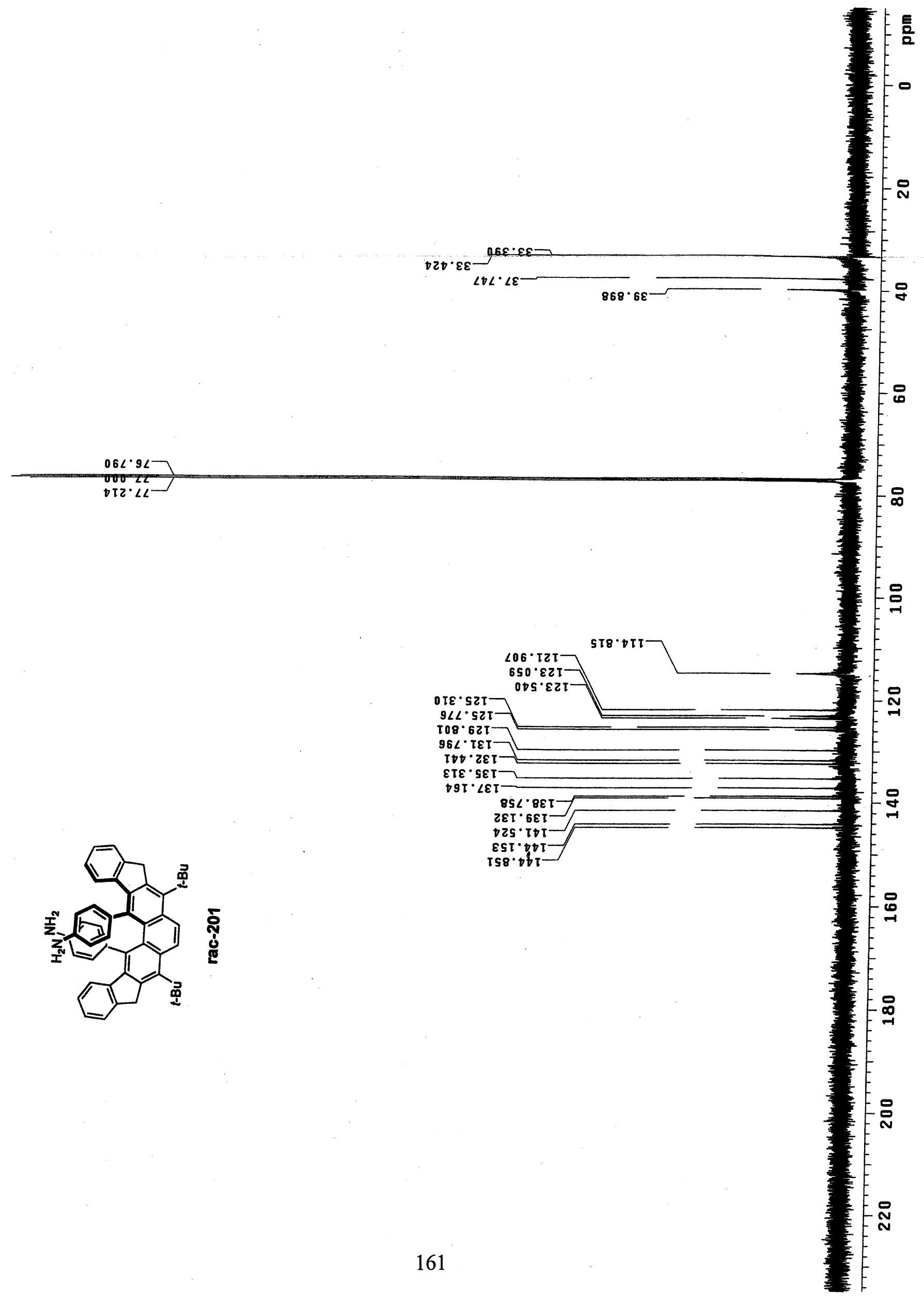




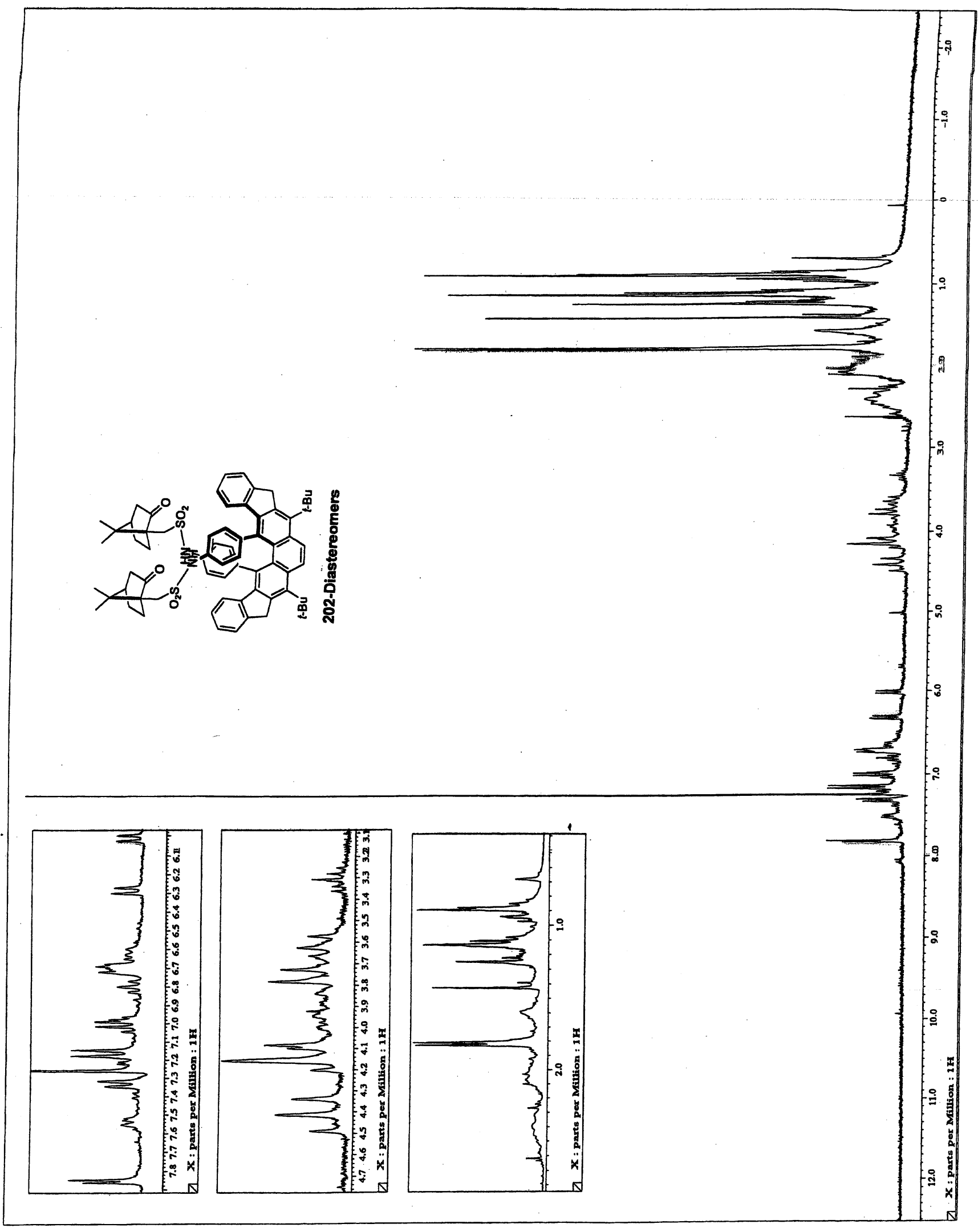




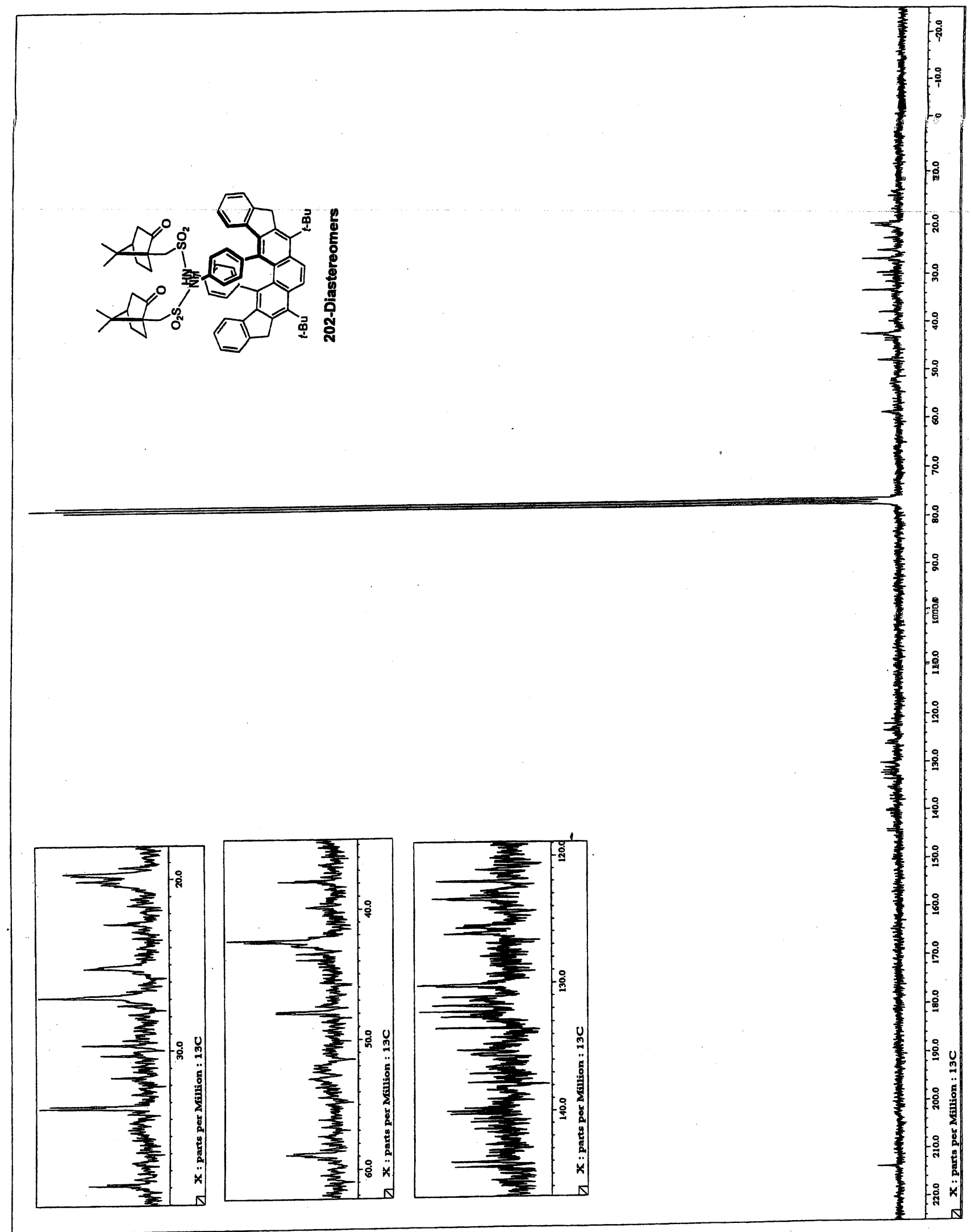




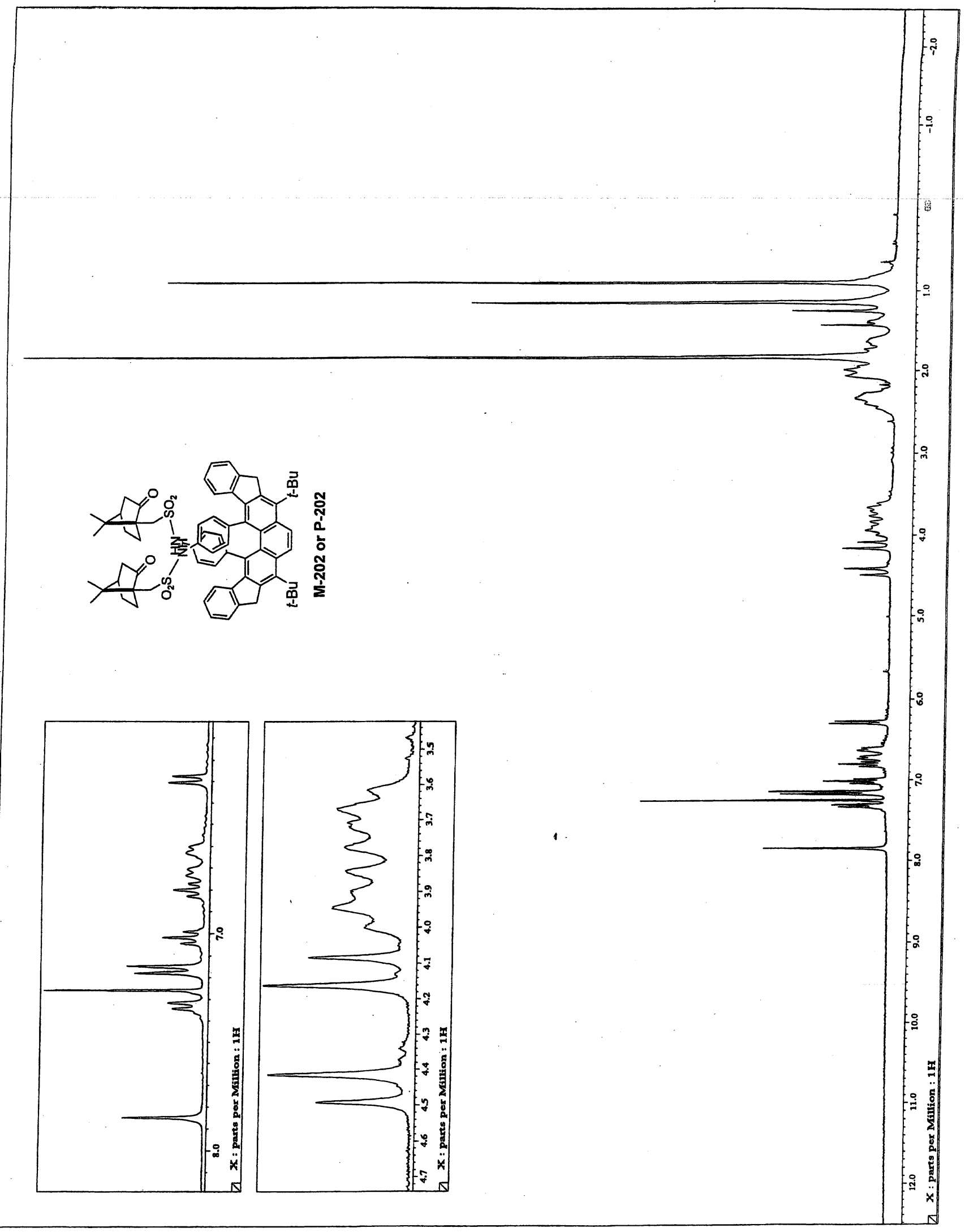




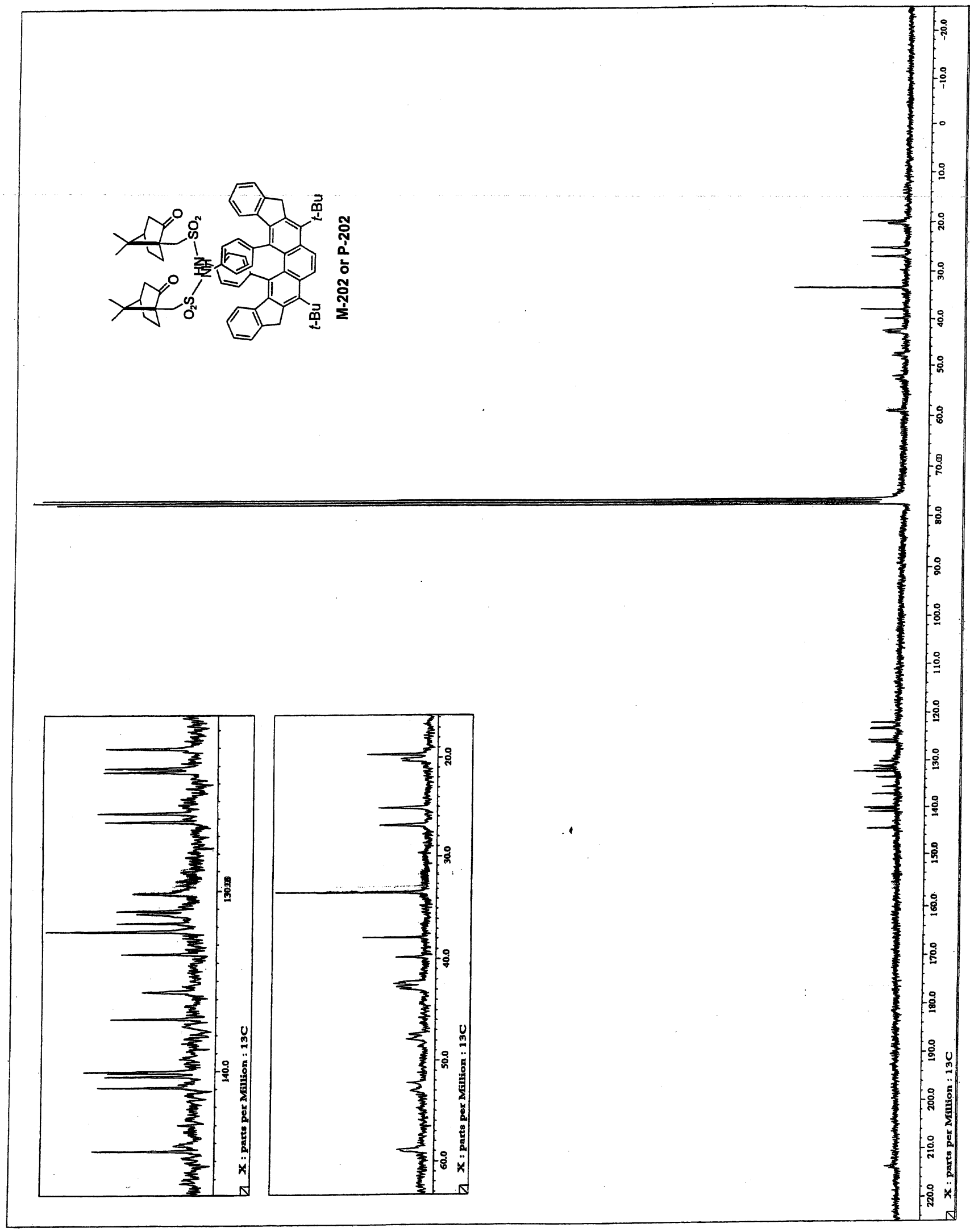




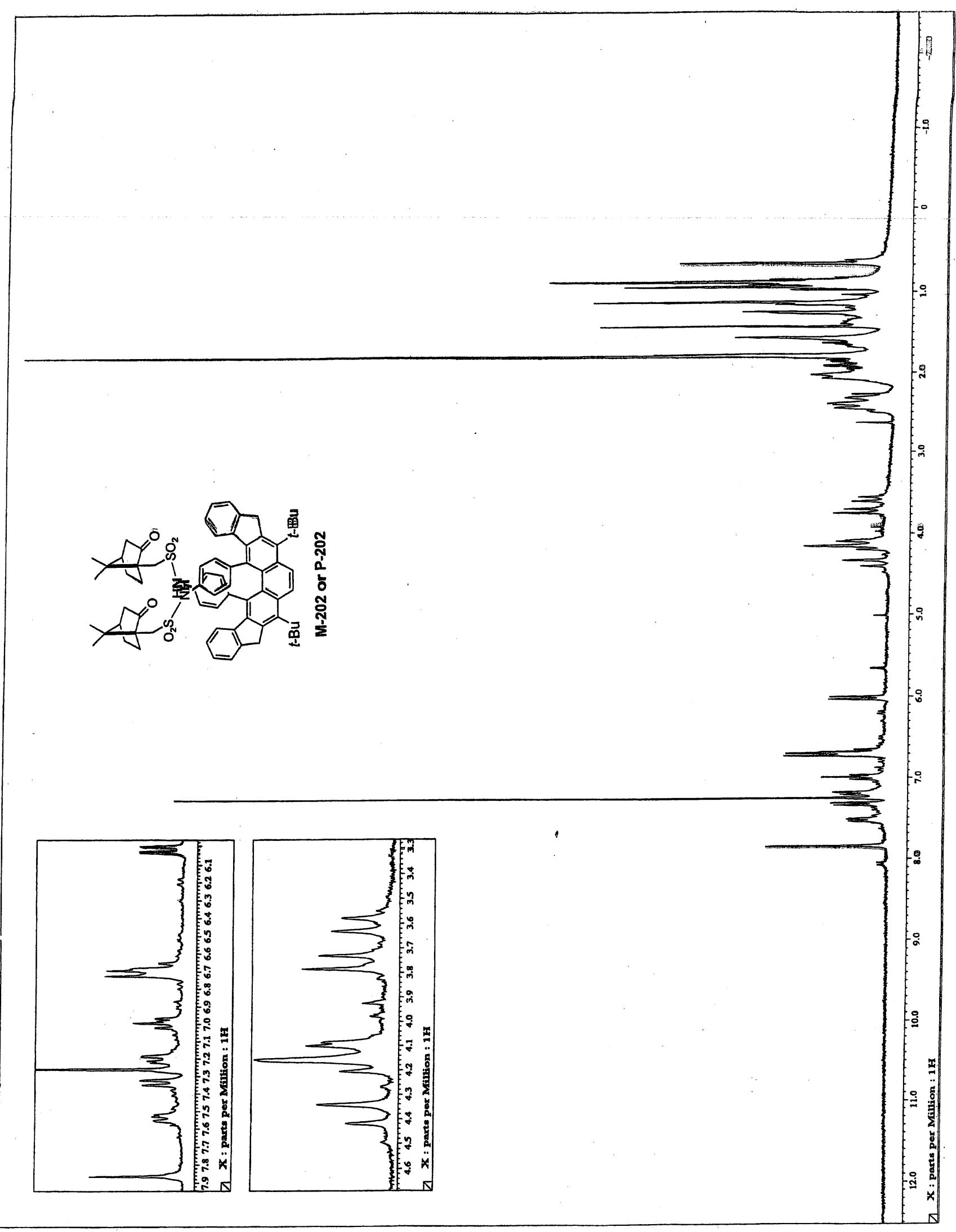




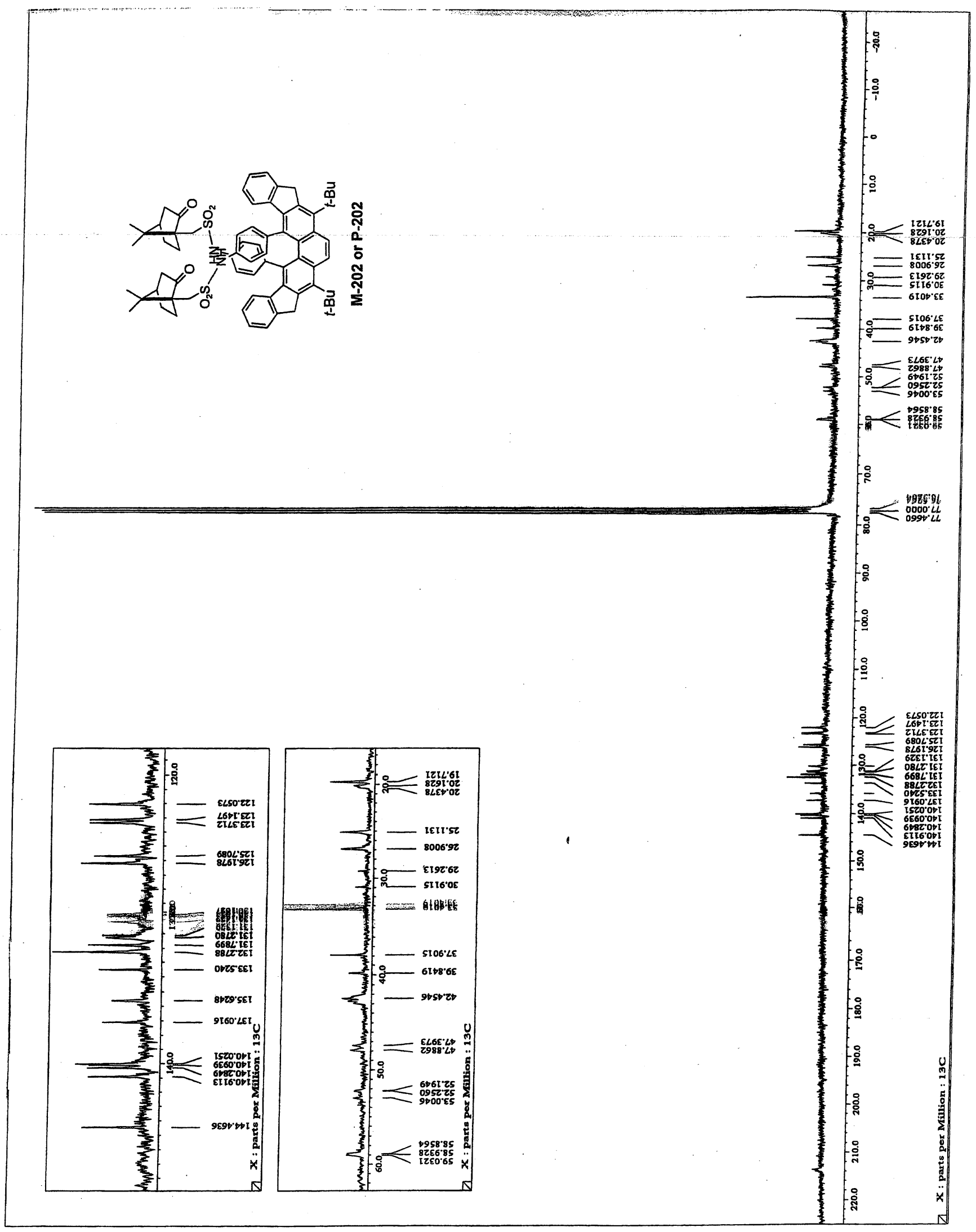




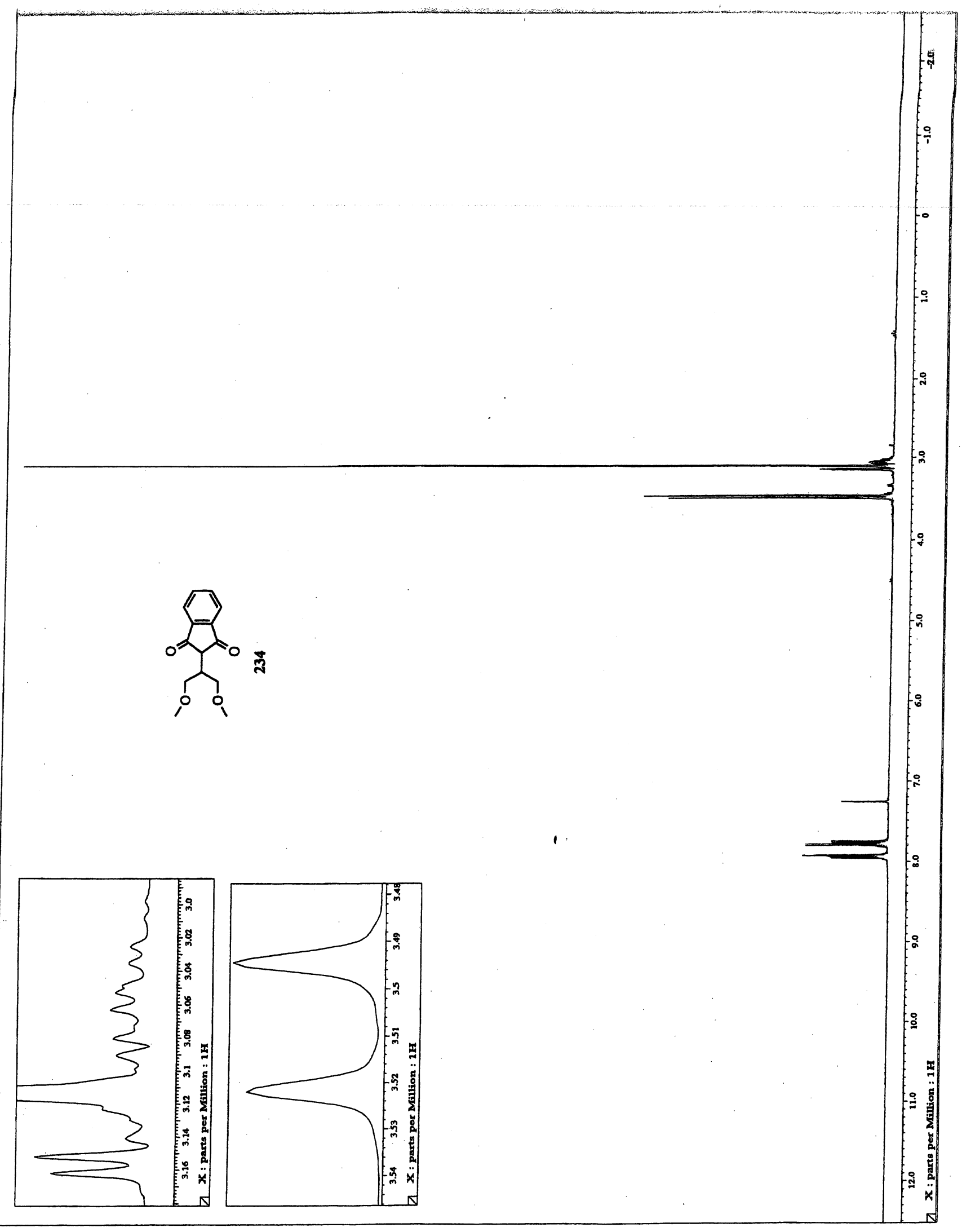




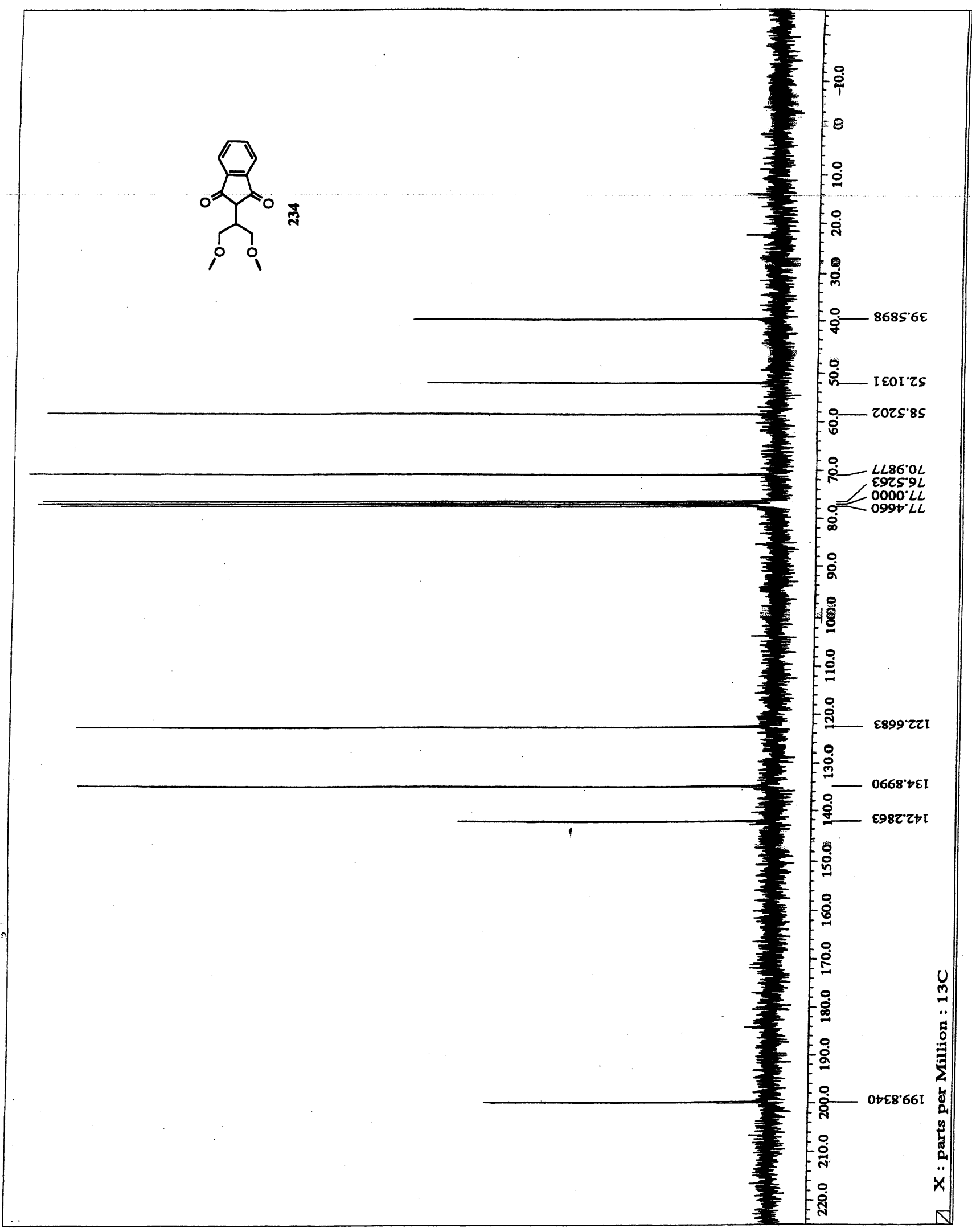




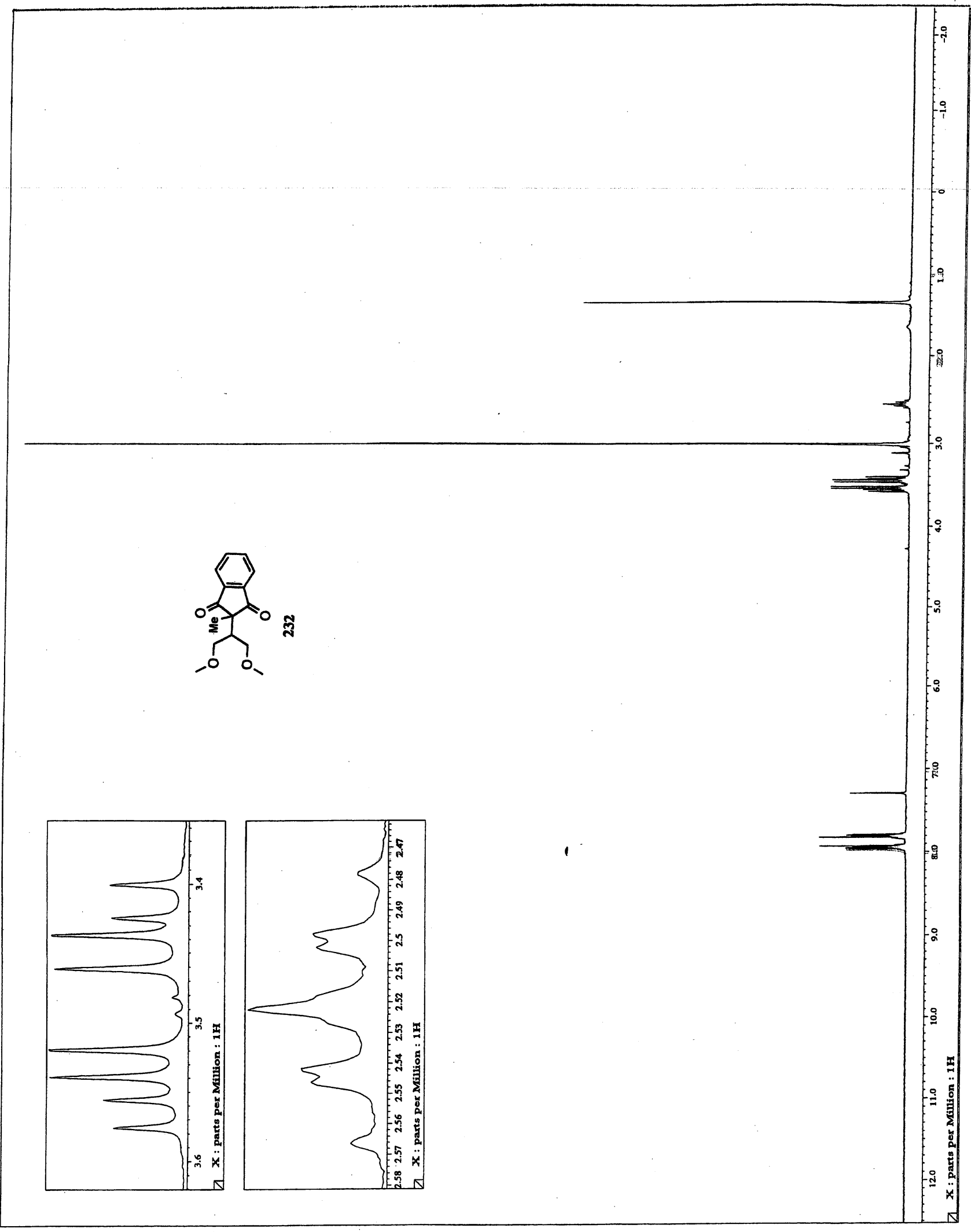




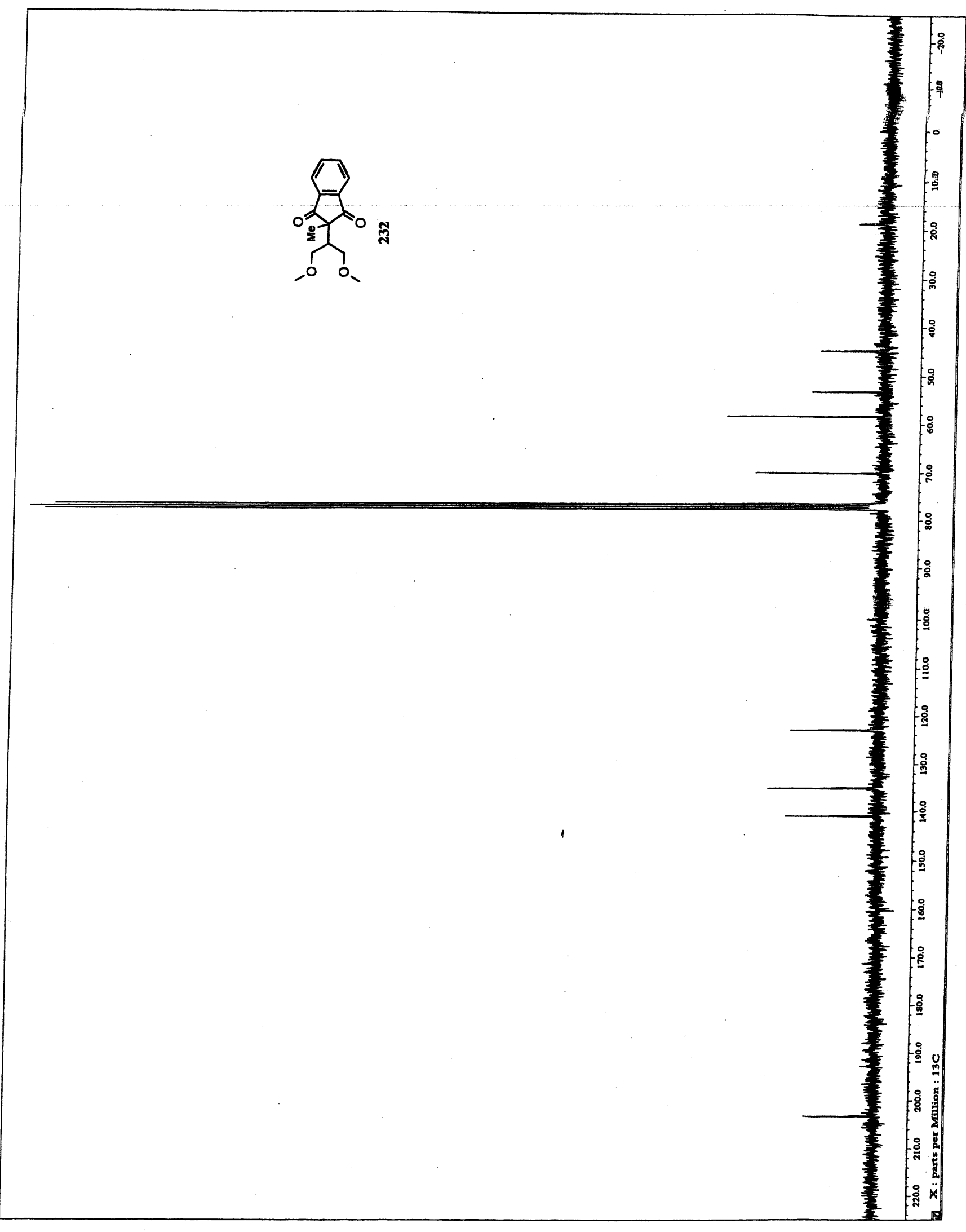




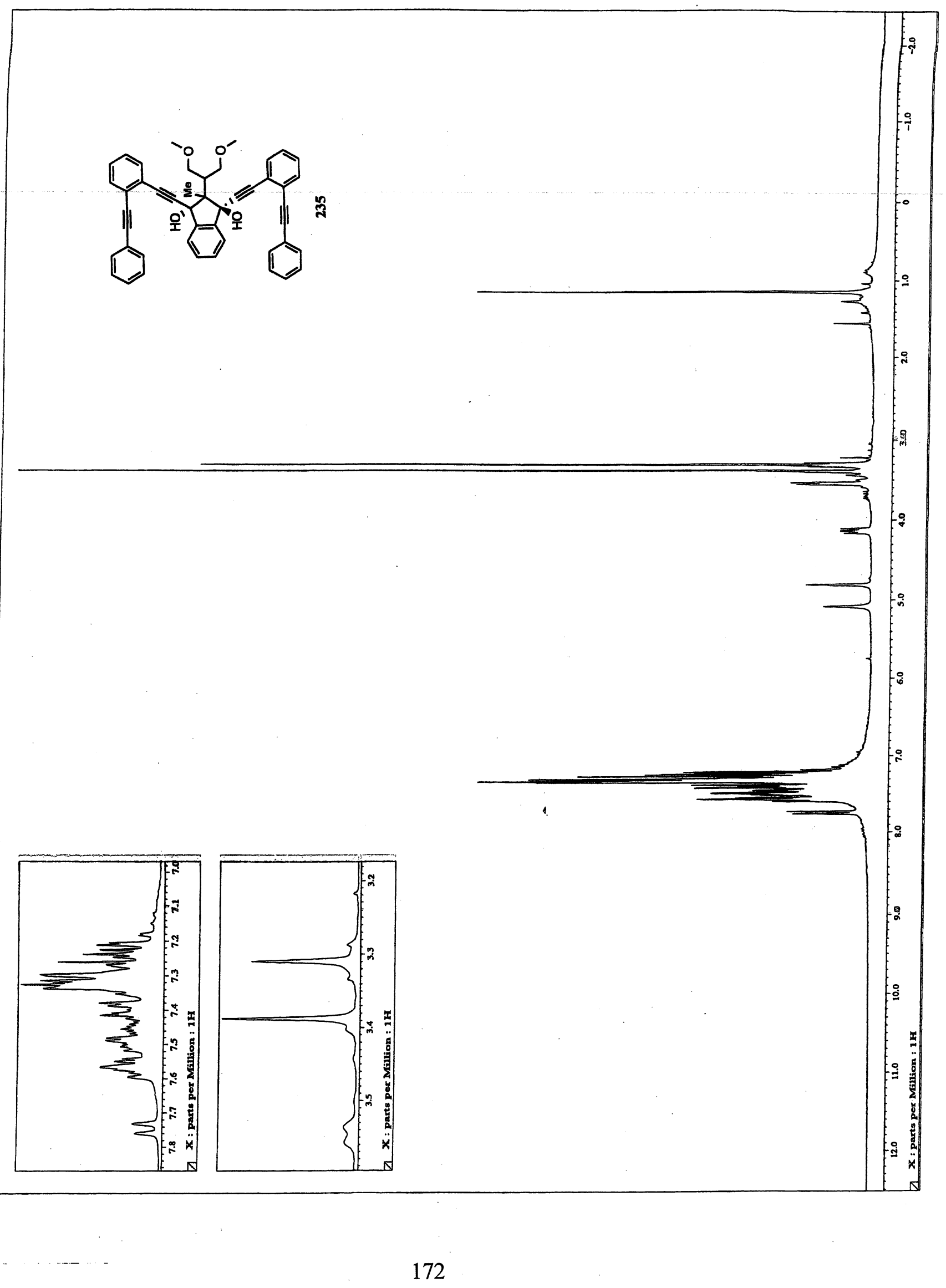




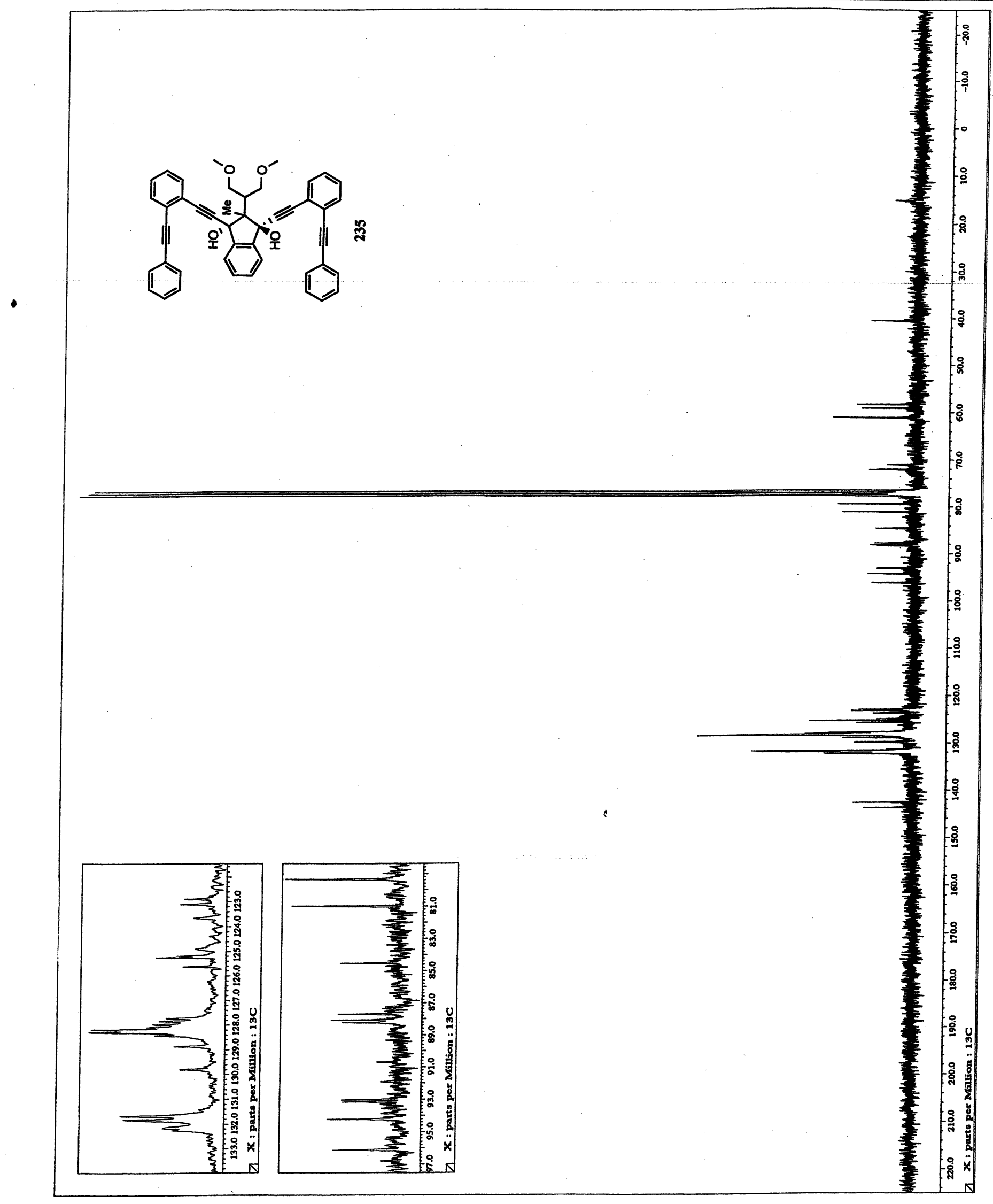




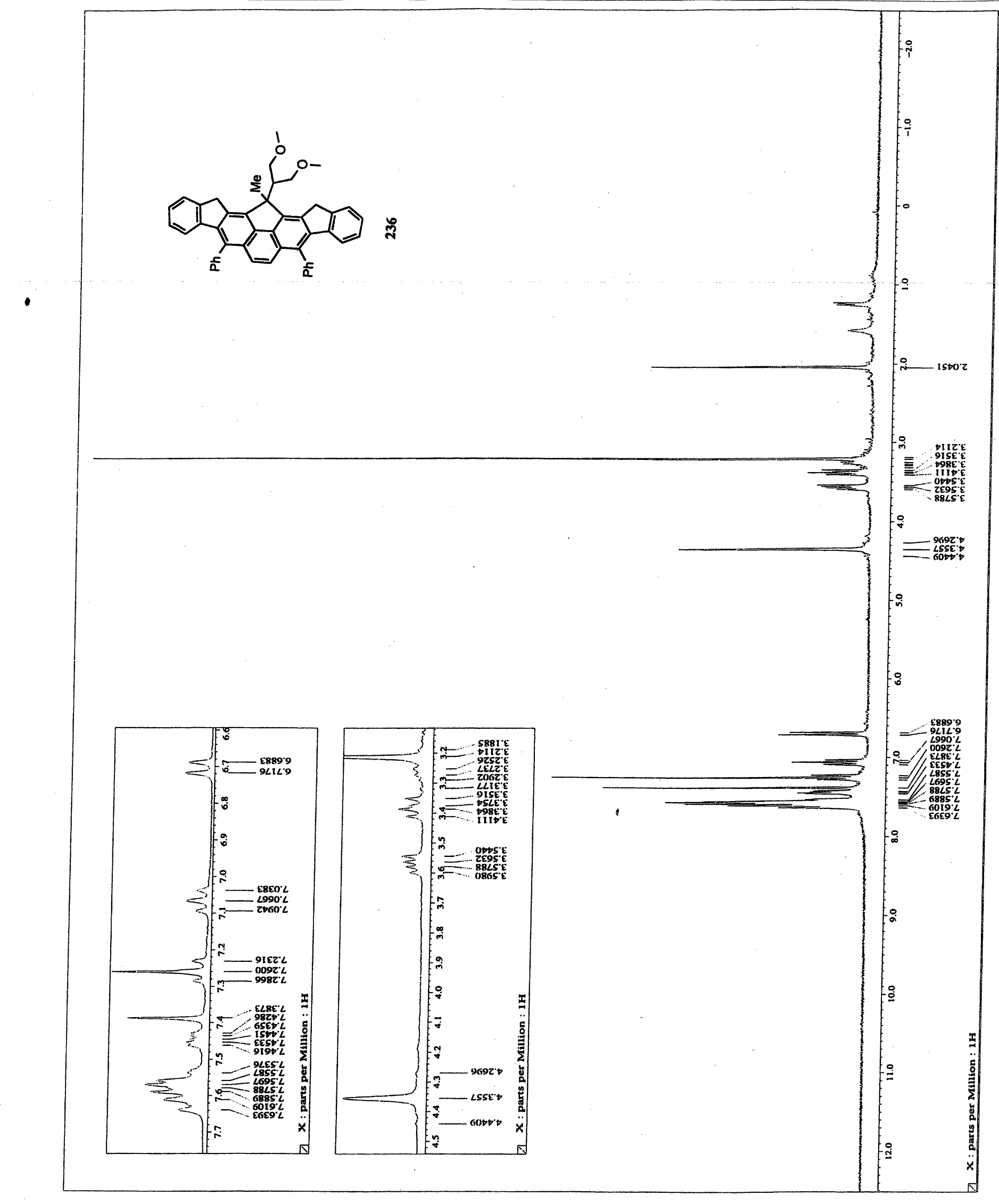




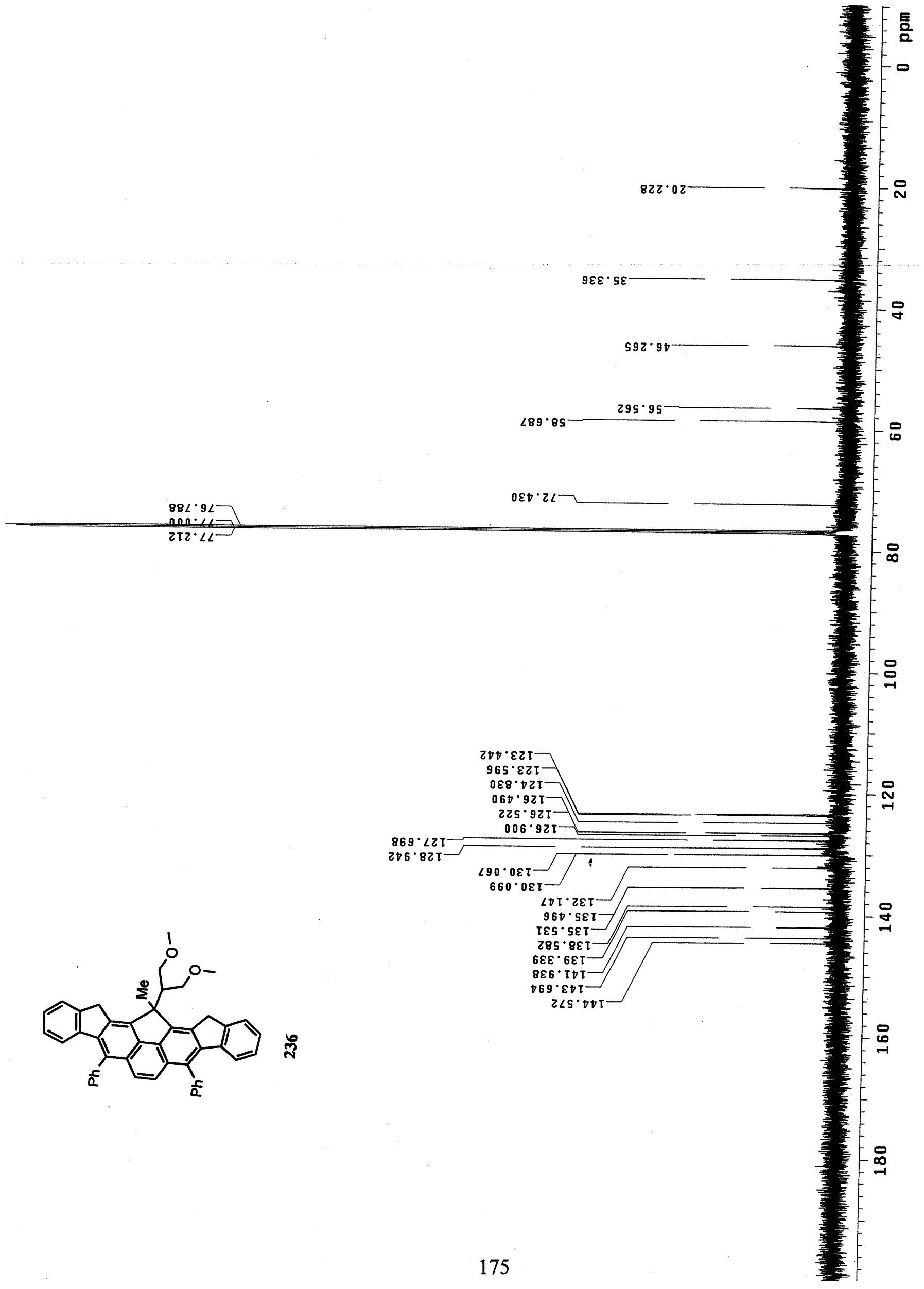




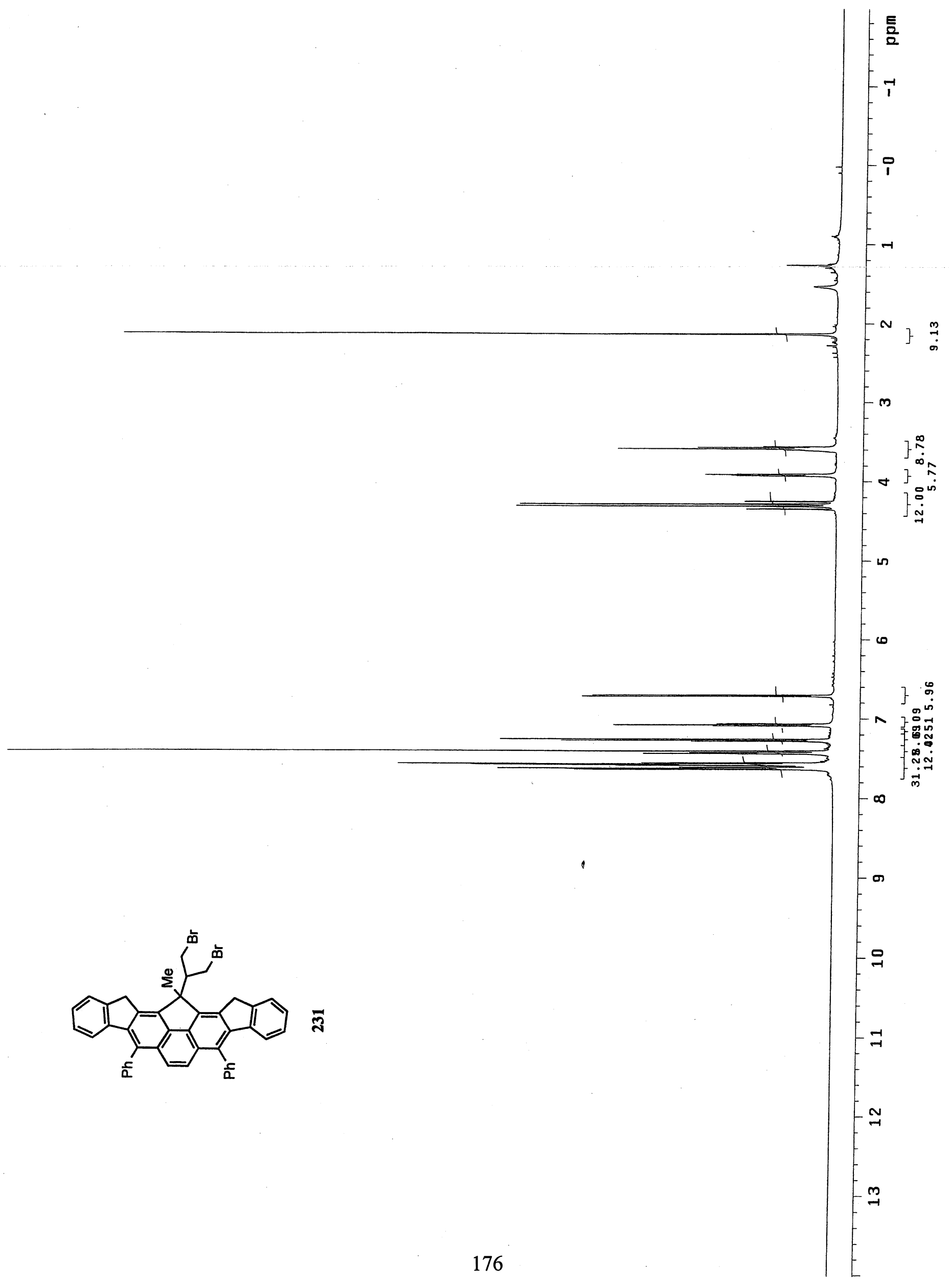




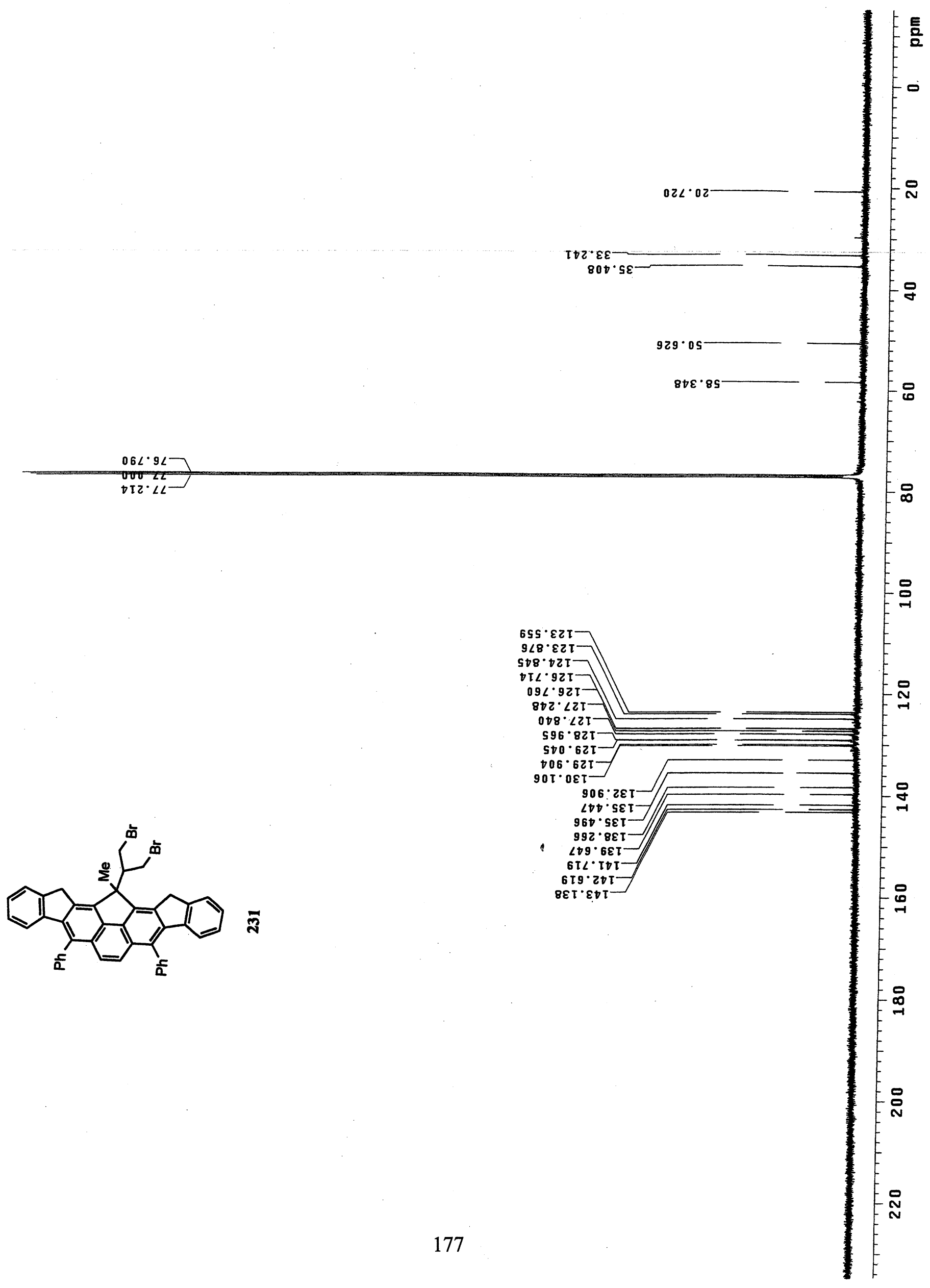




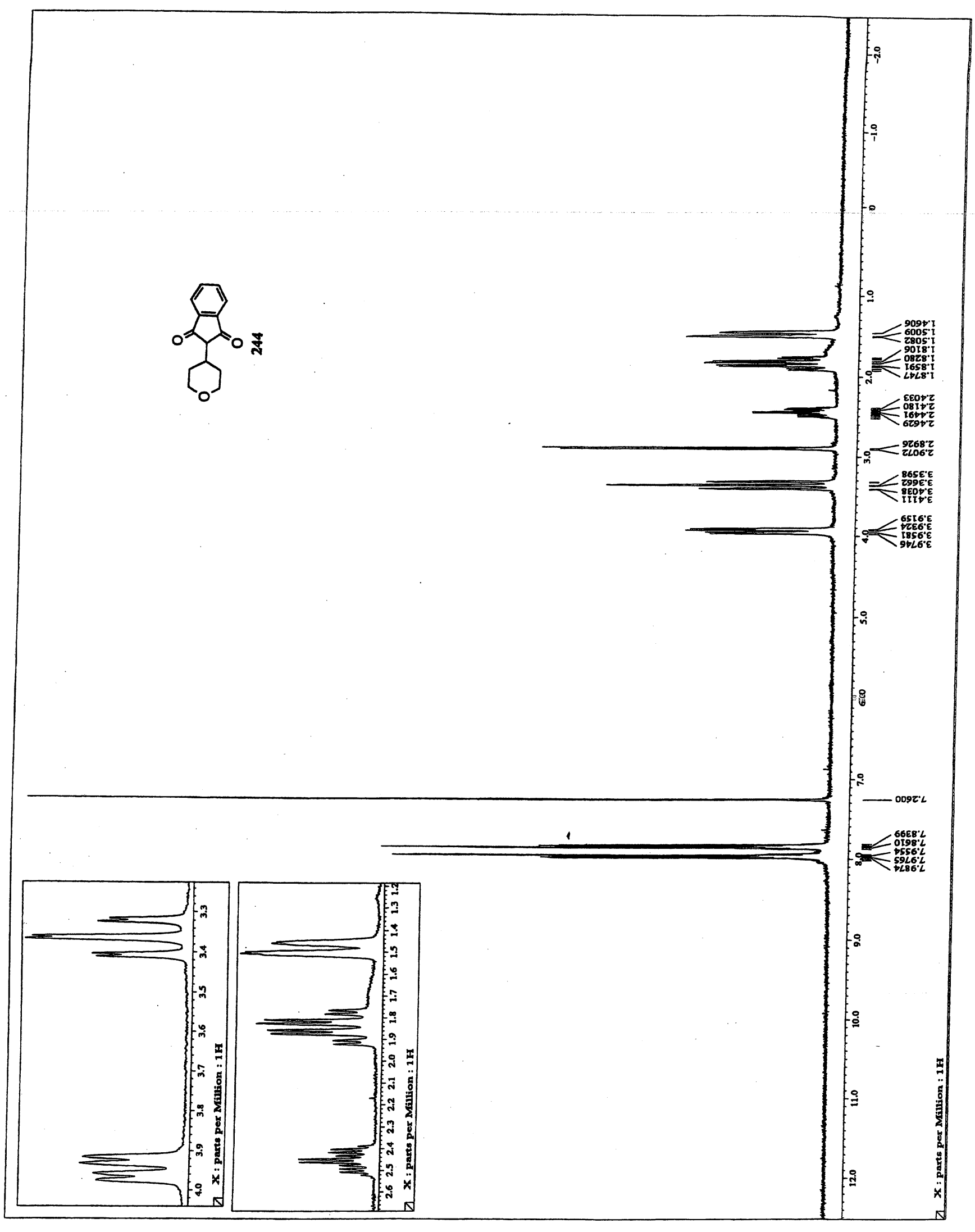




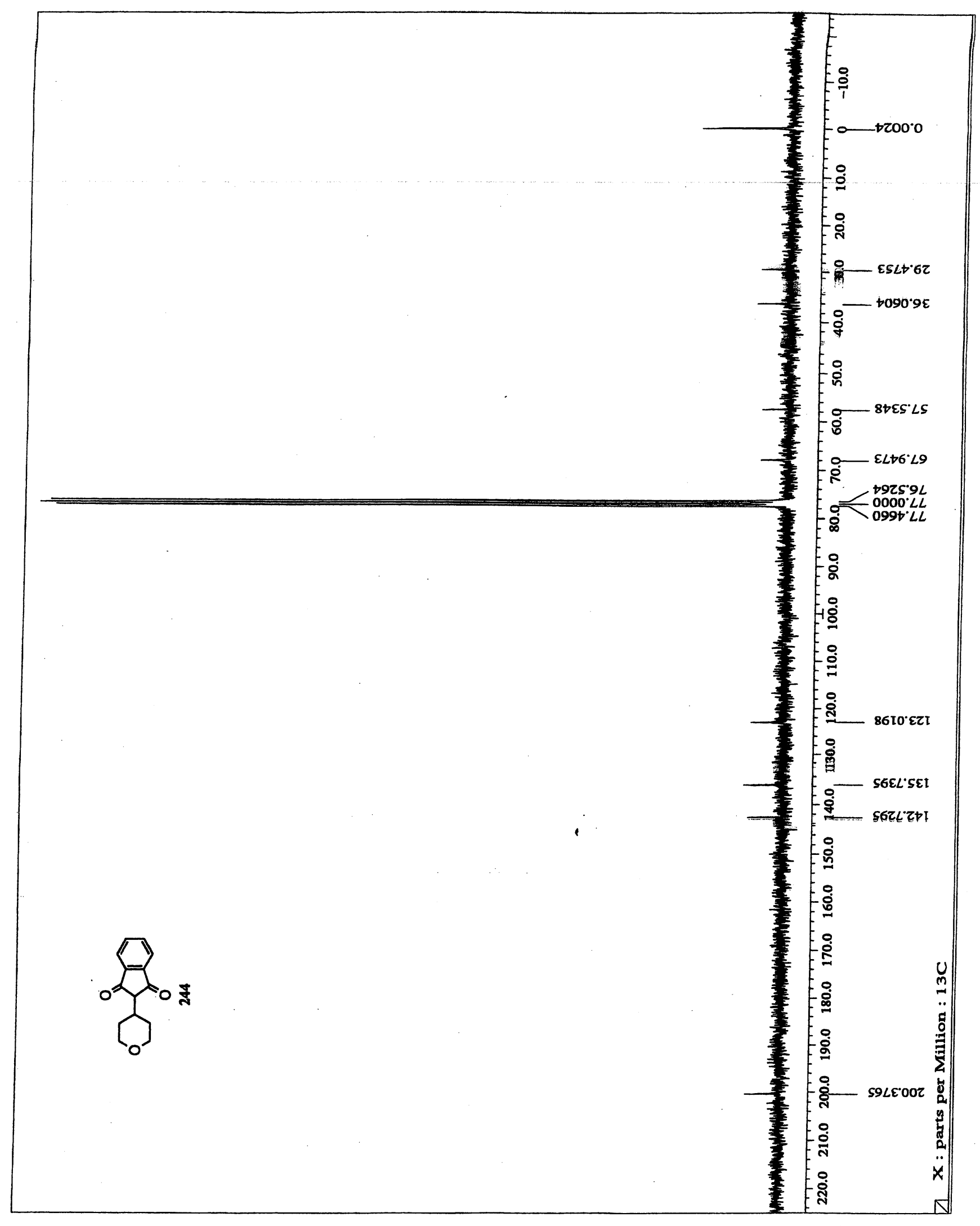




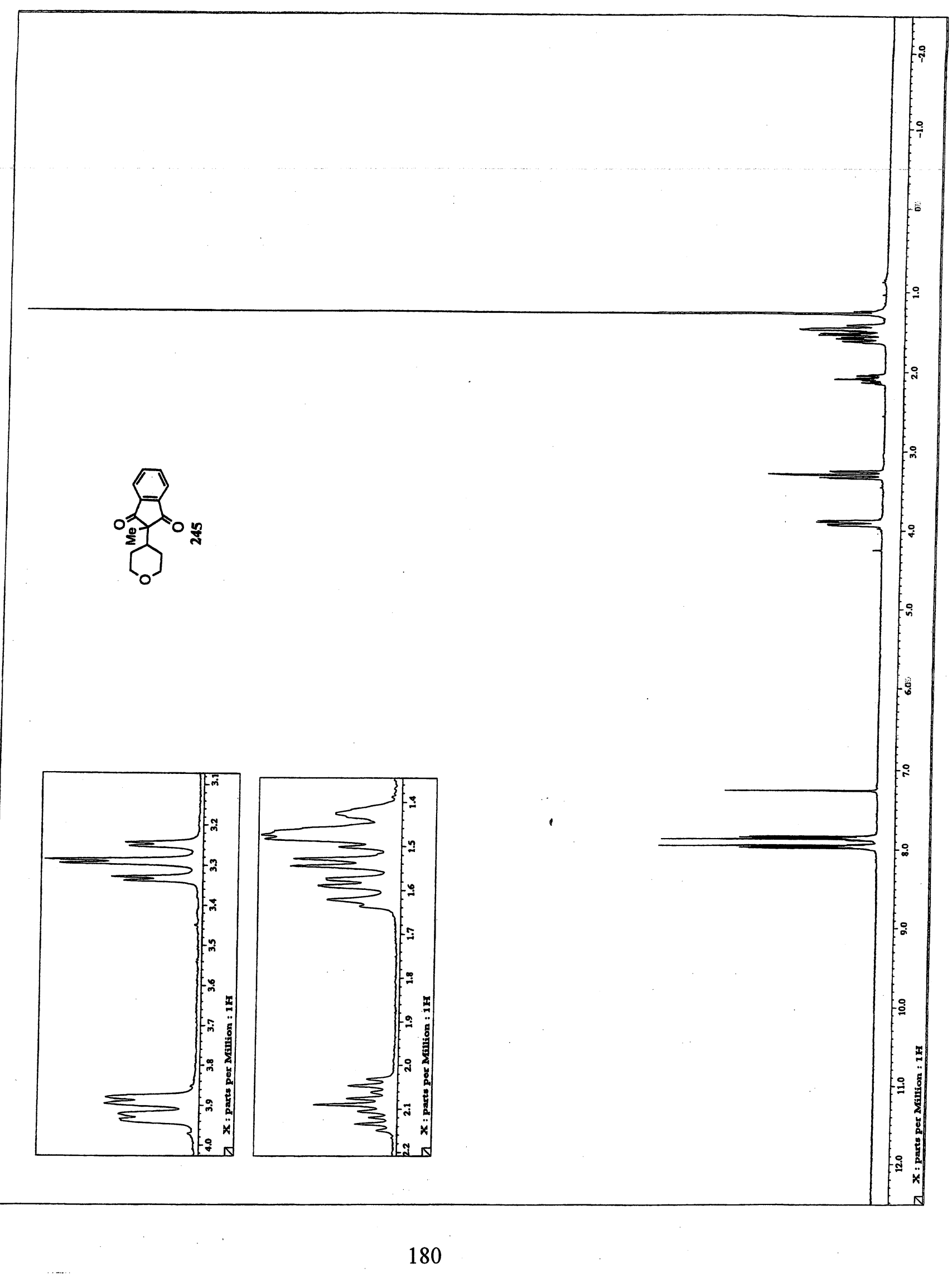




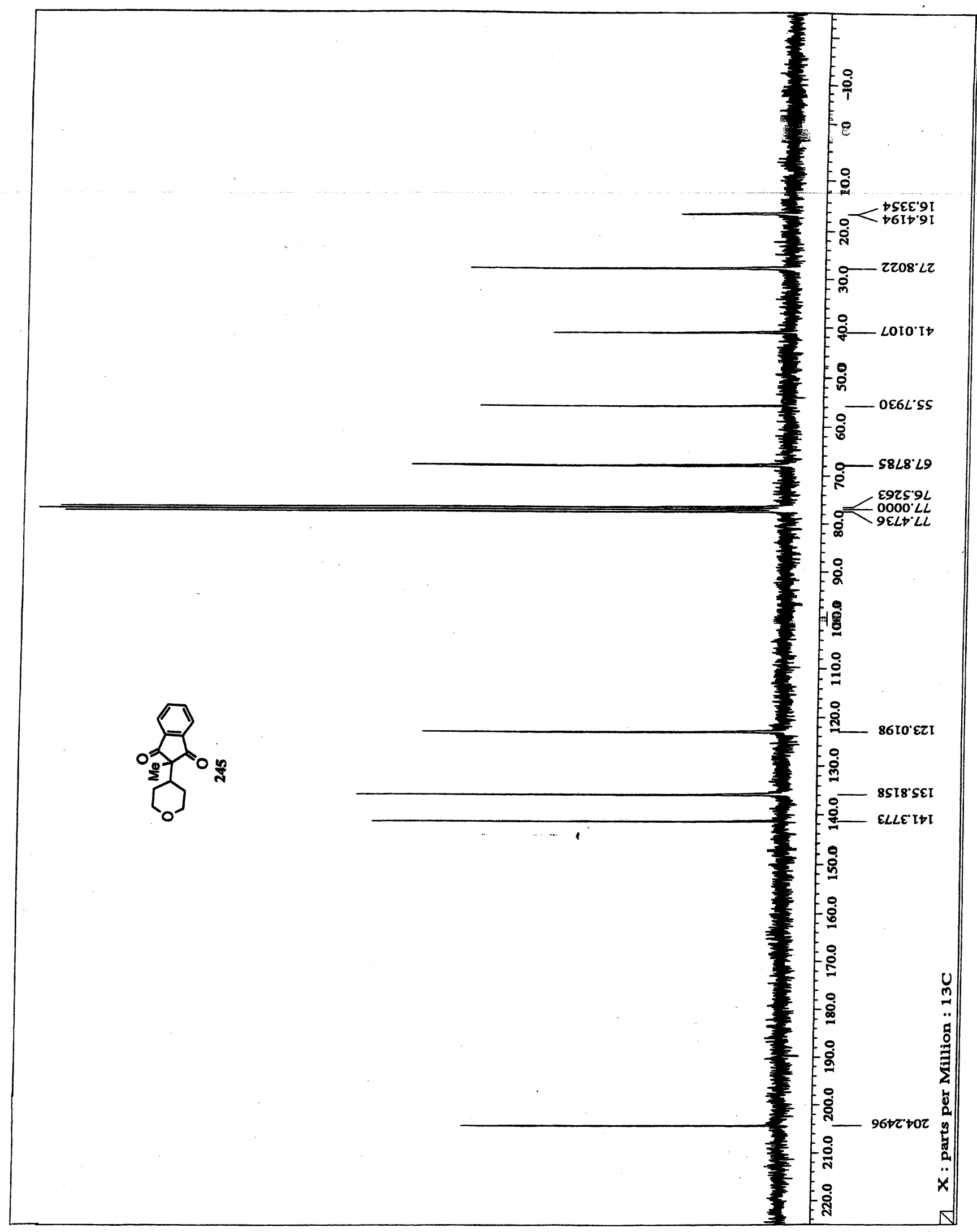




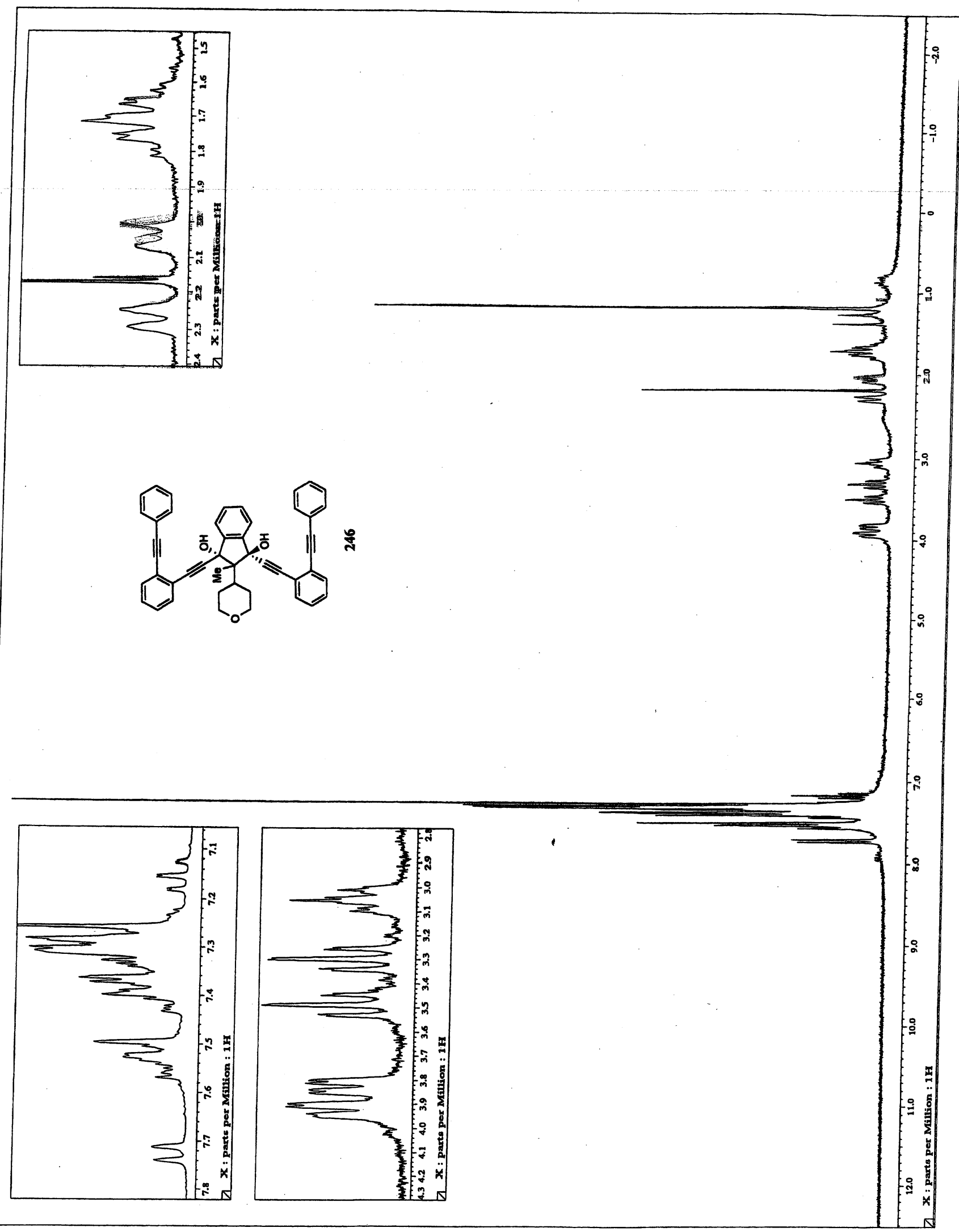




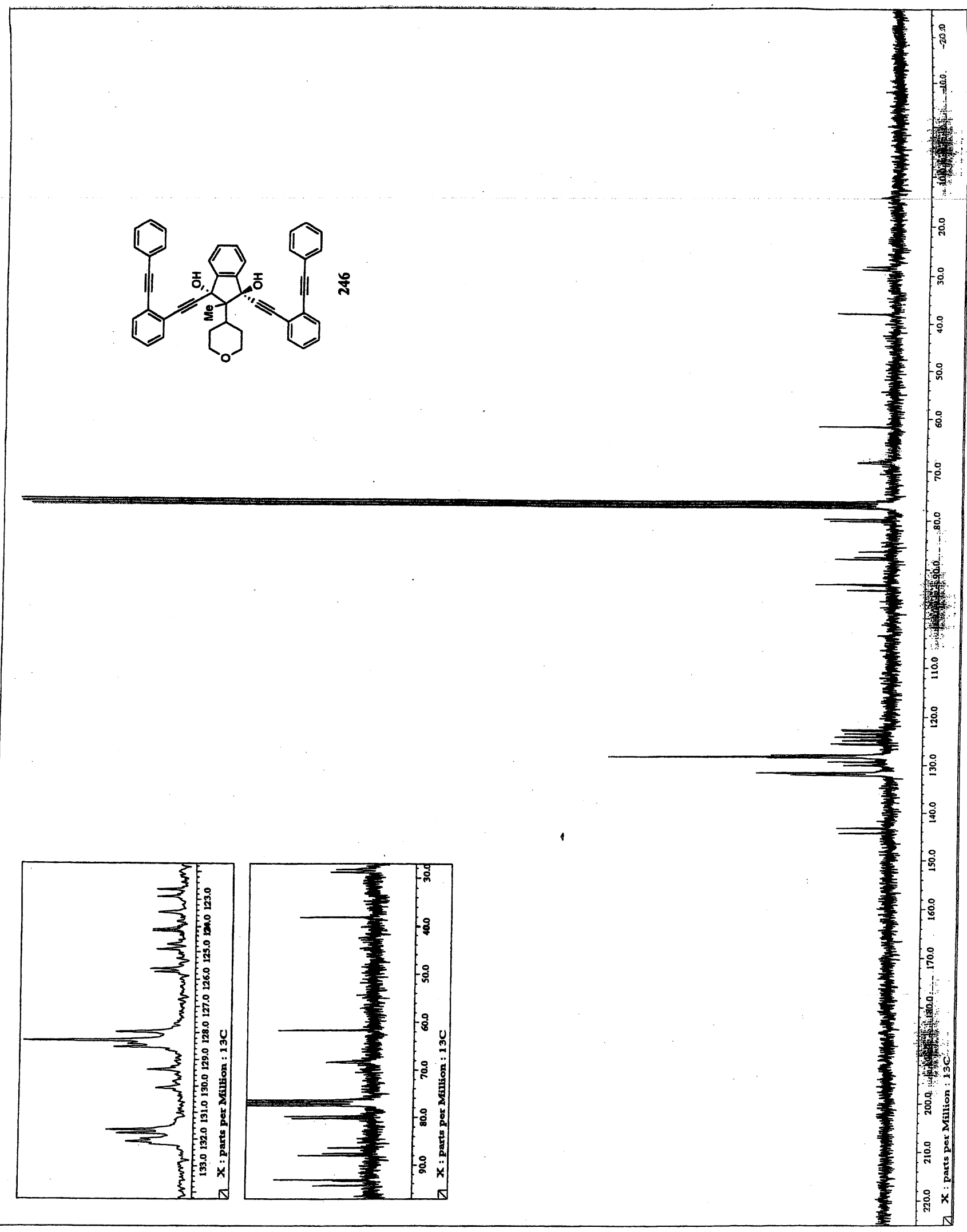




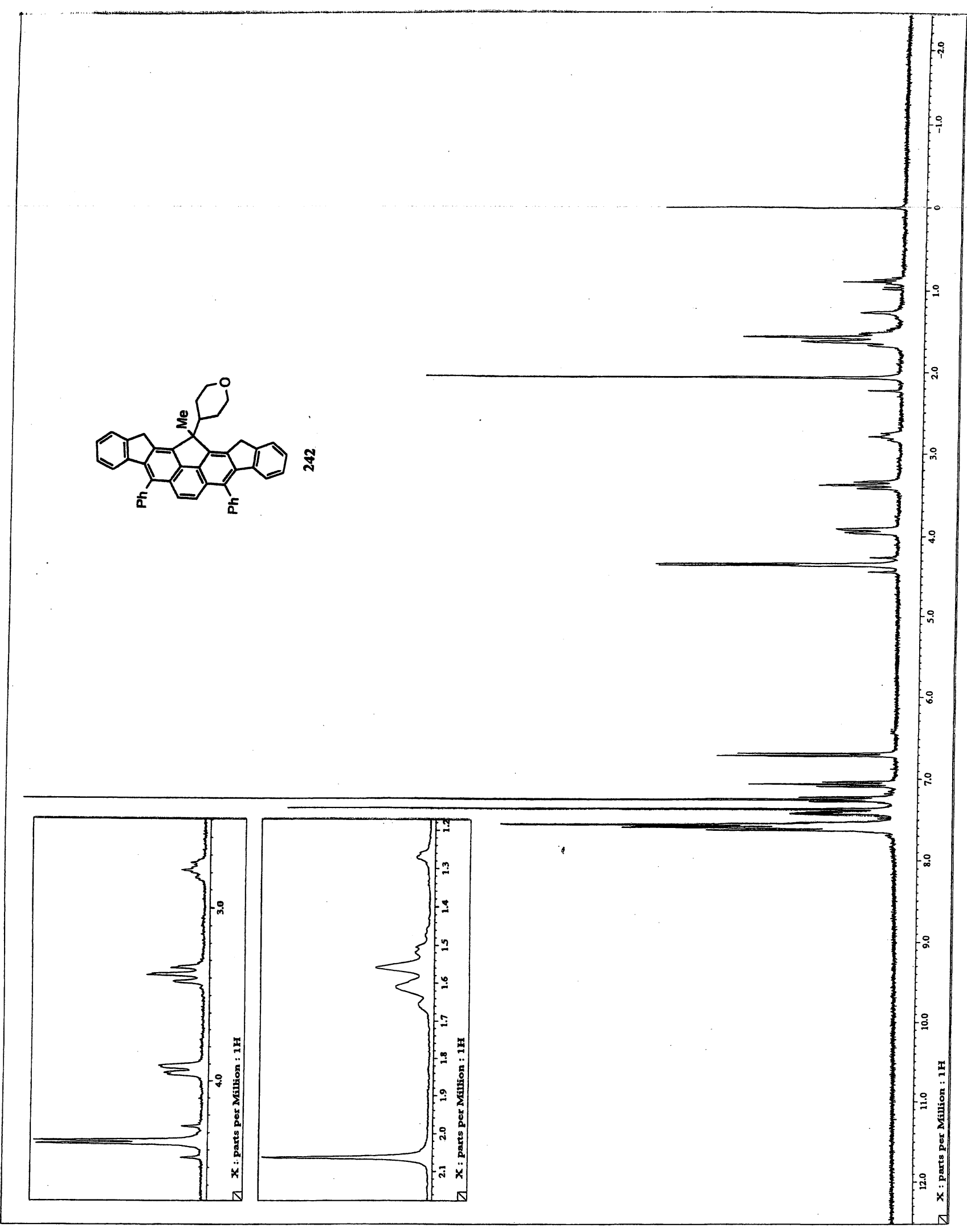




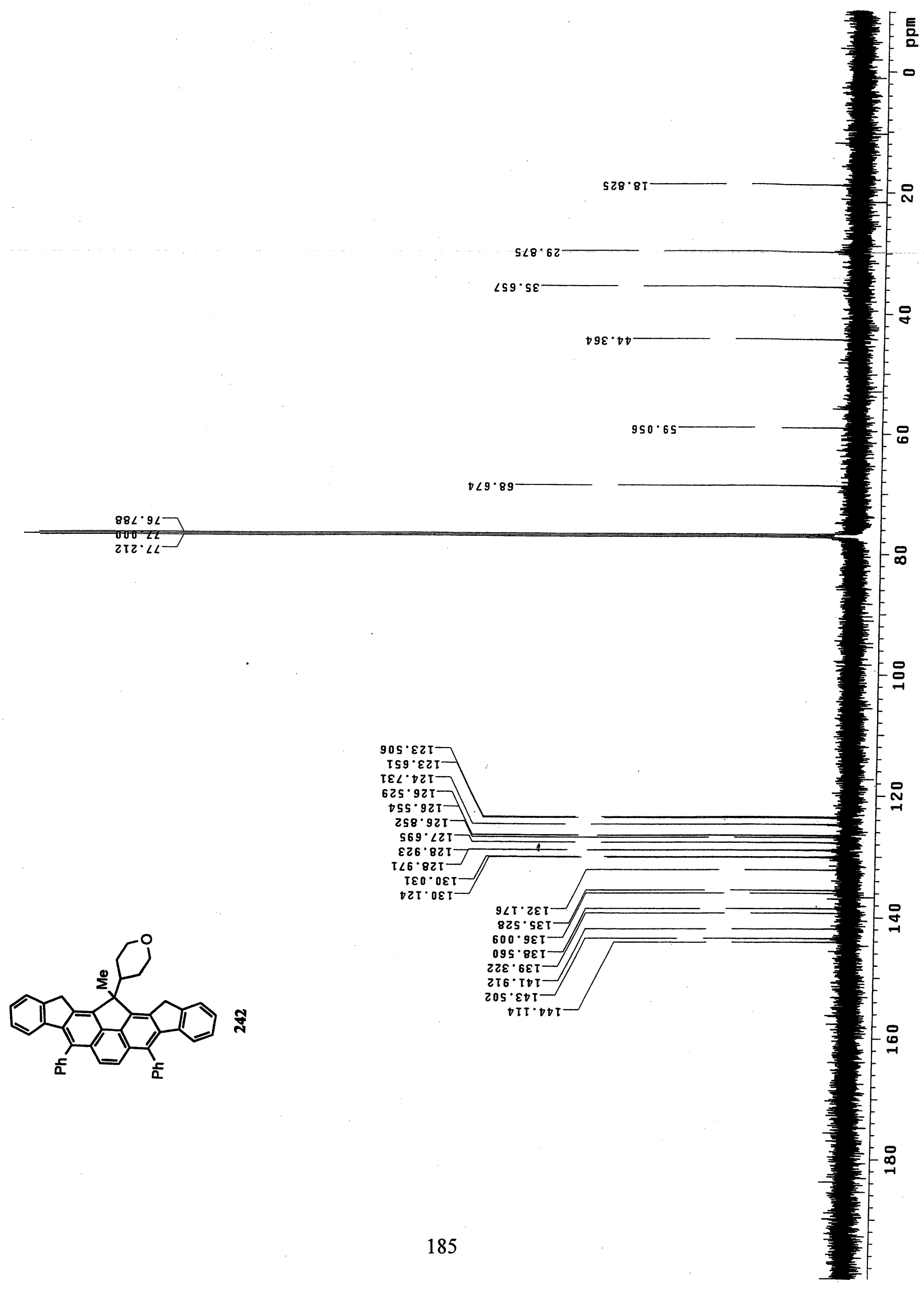




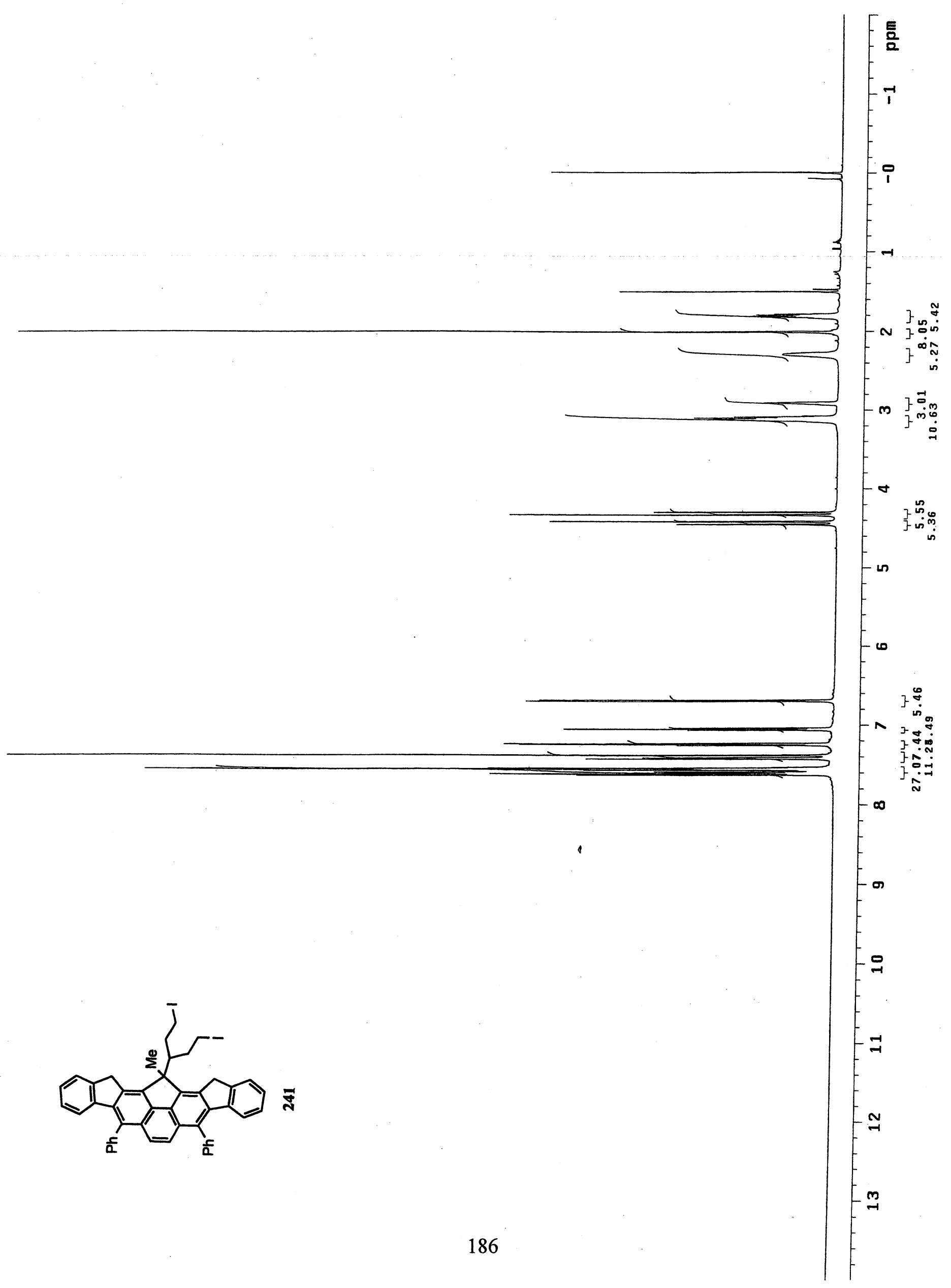




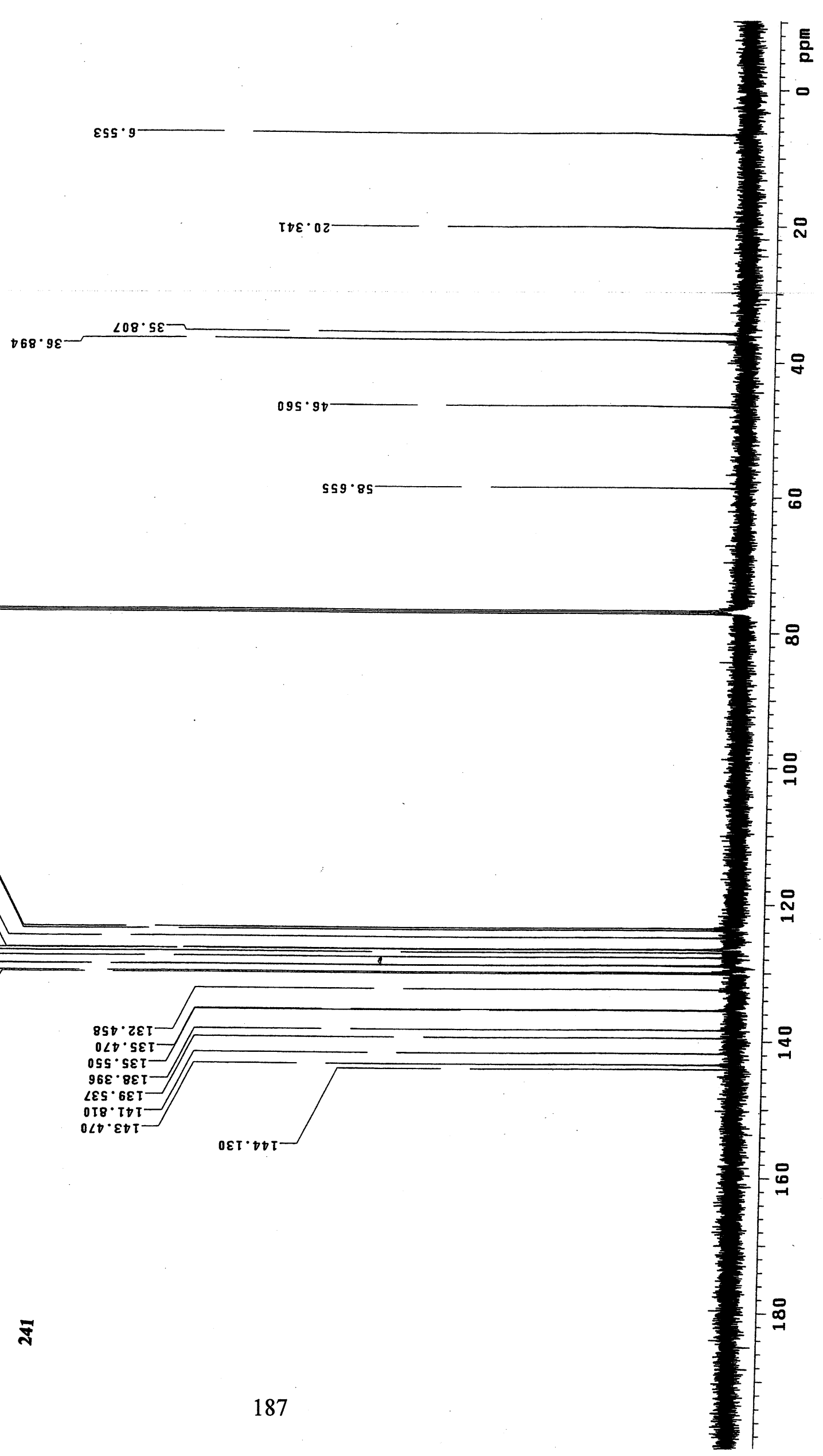




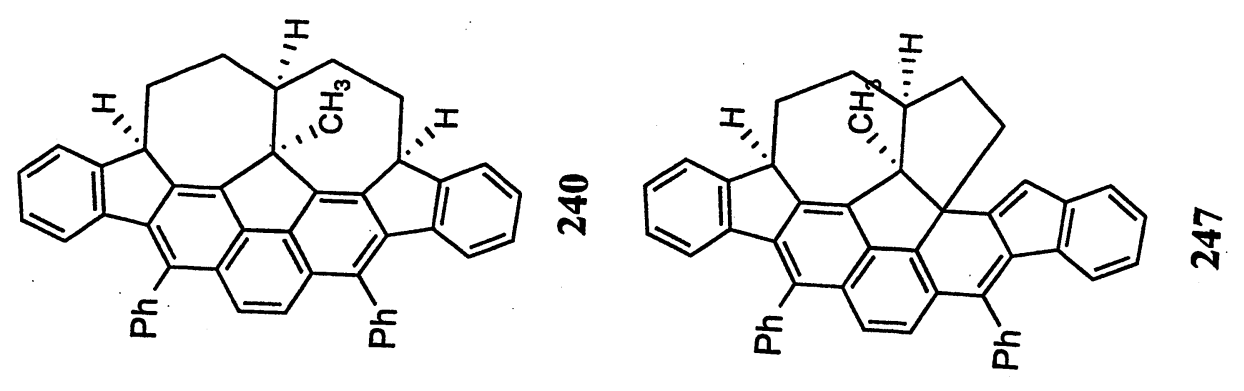

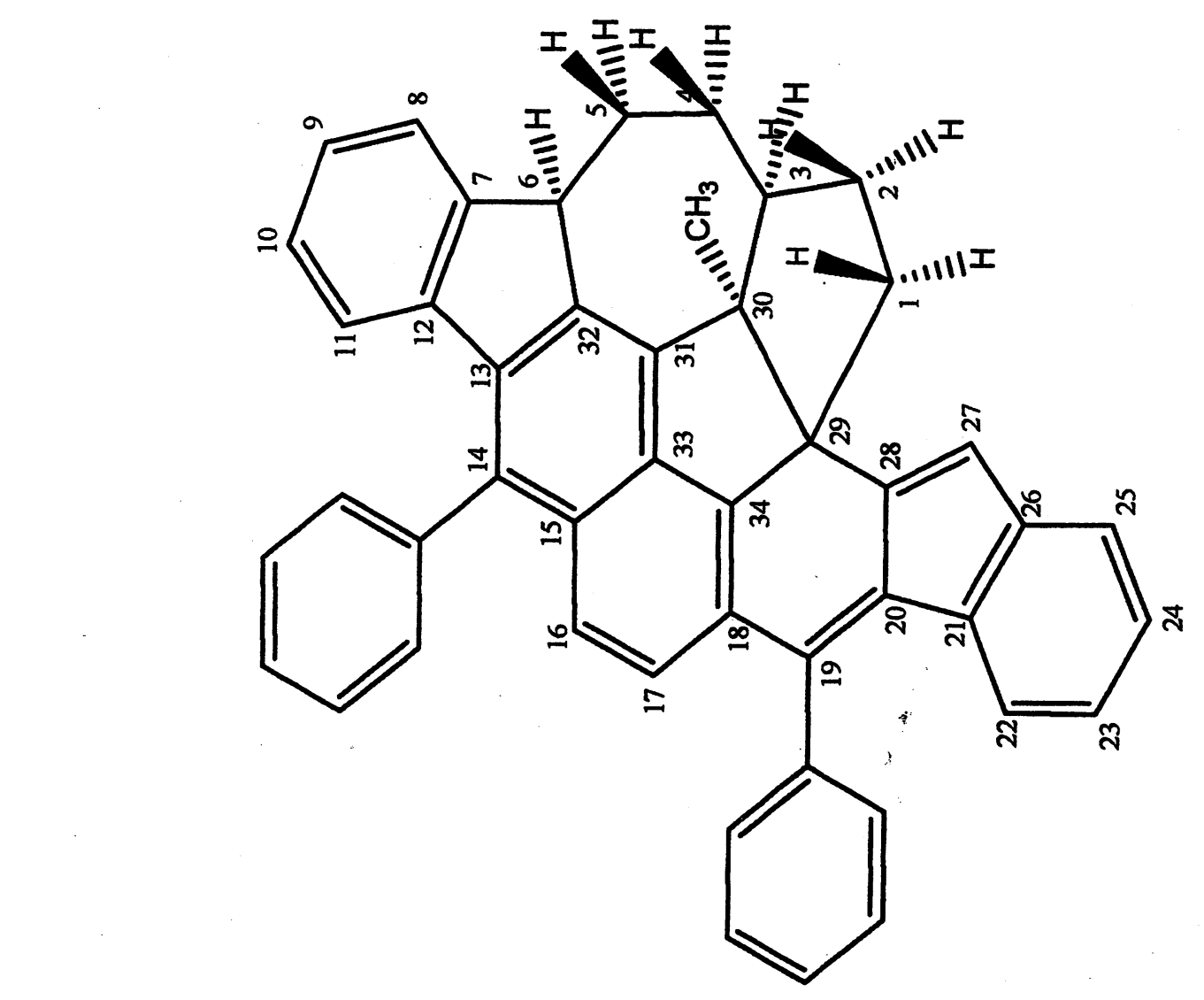




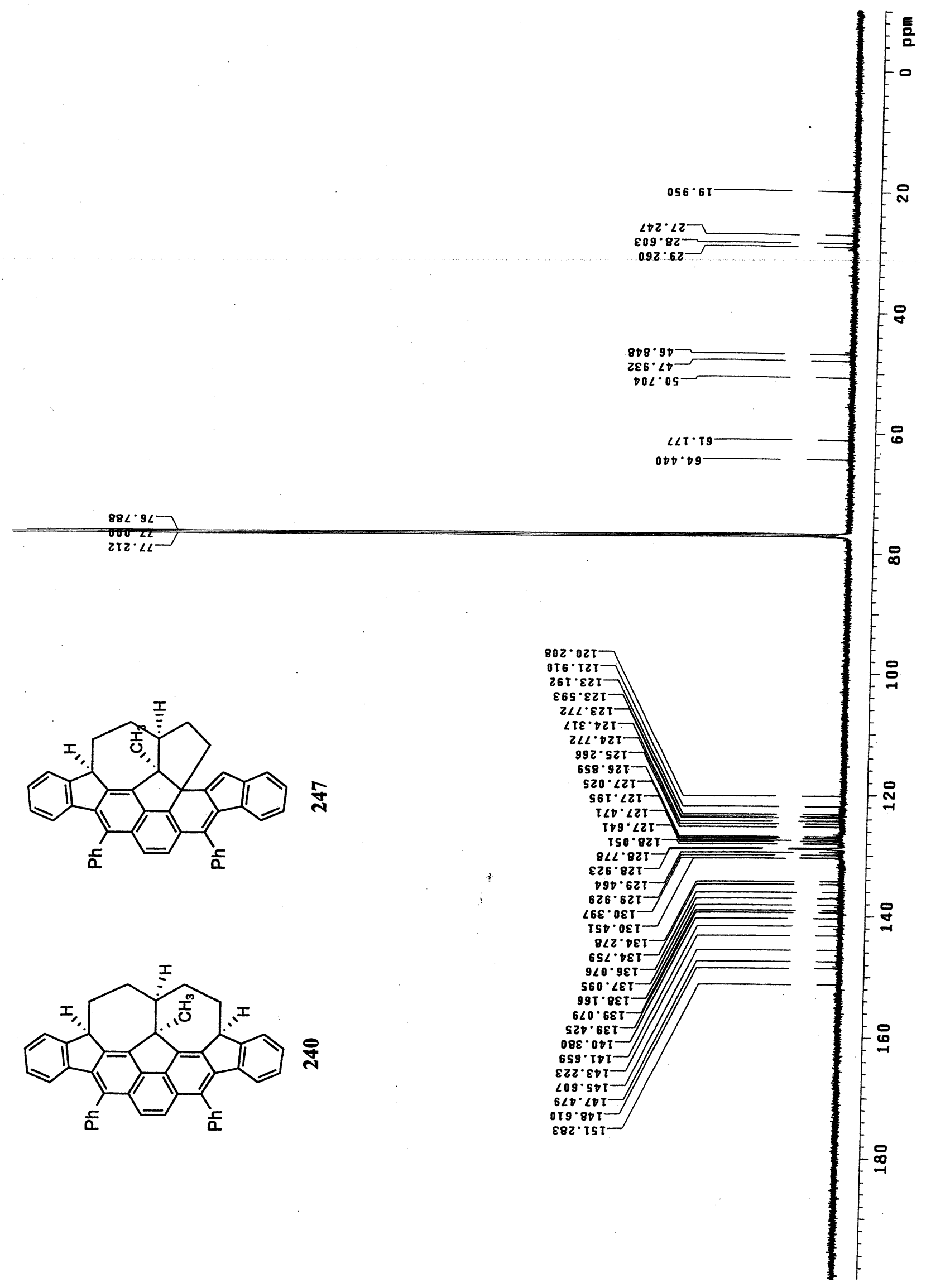




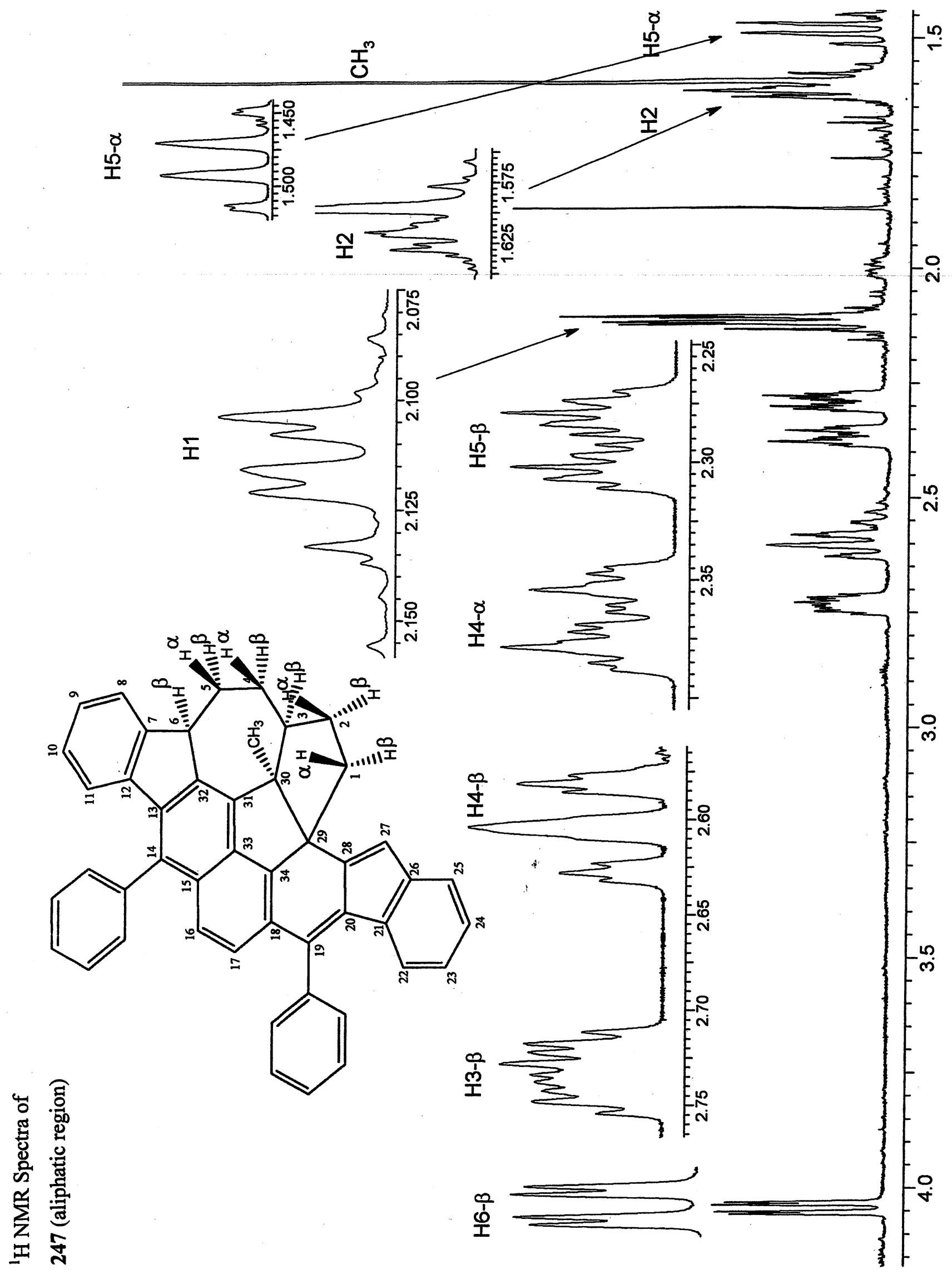




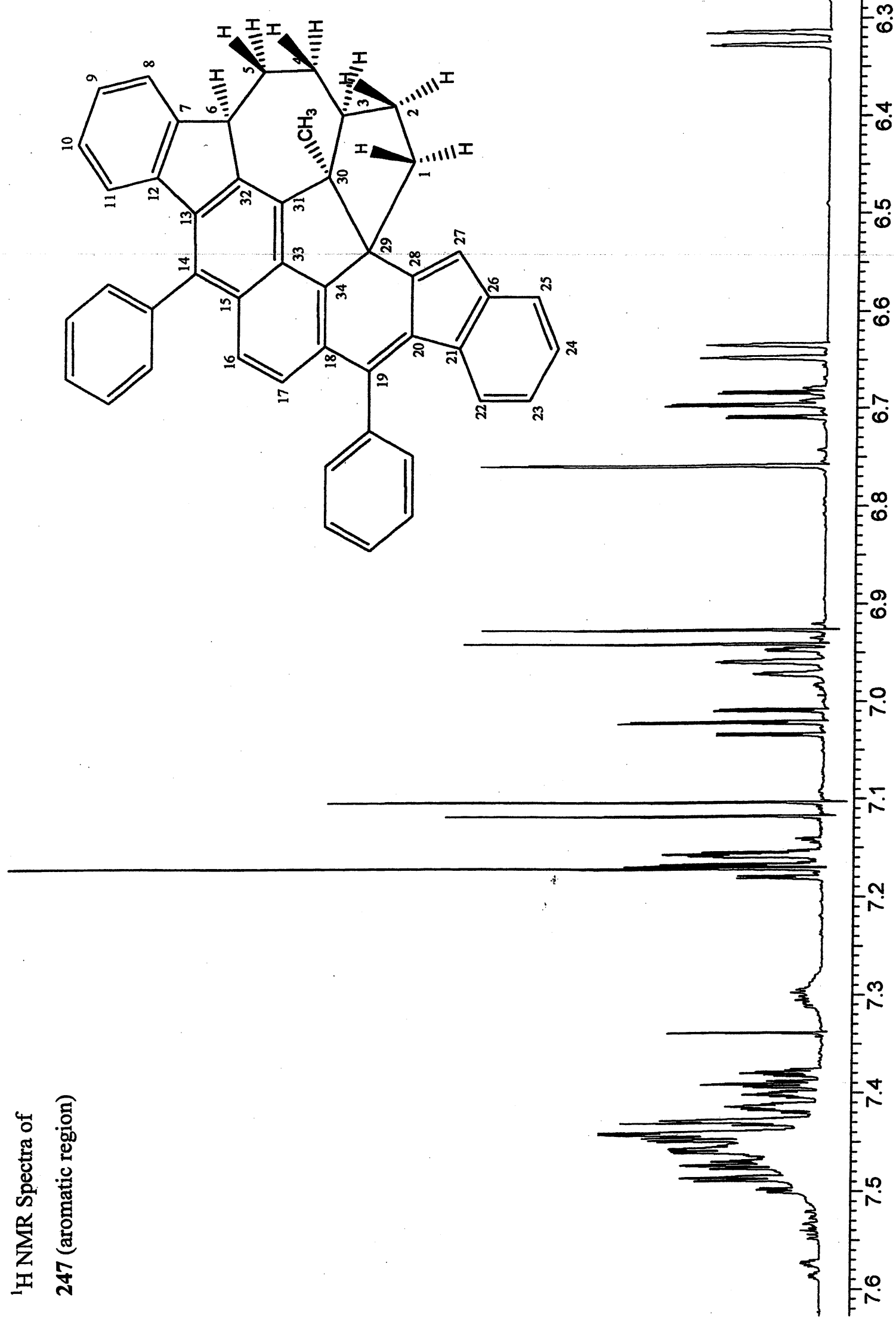


gHMQC spectra of $\mathbf{2 4 7}$
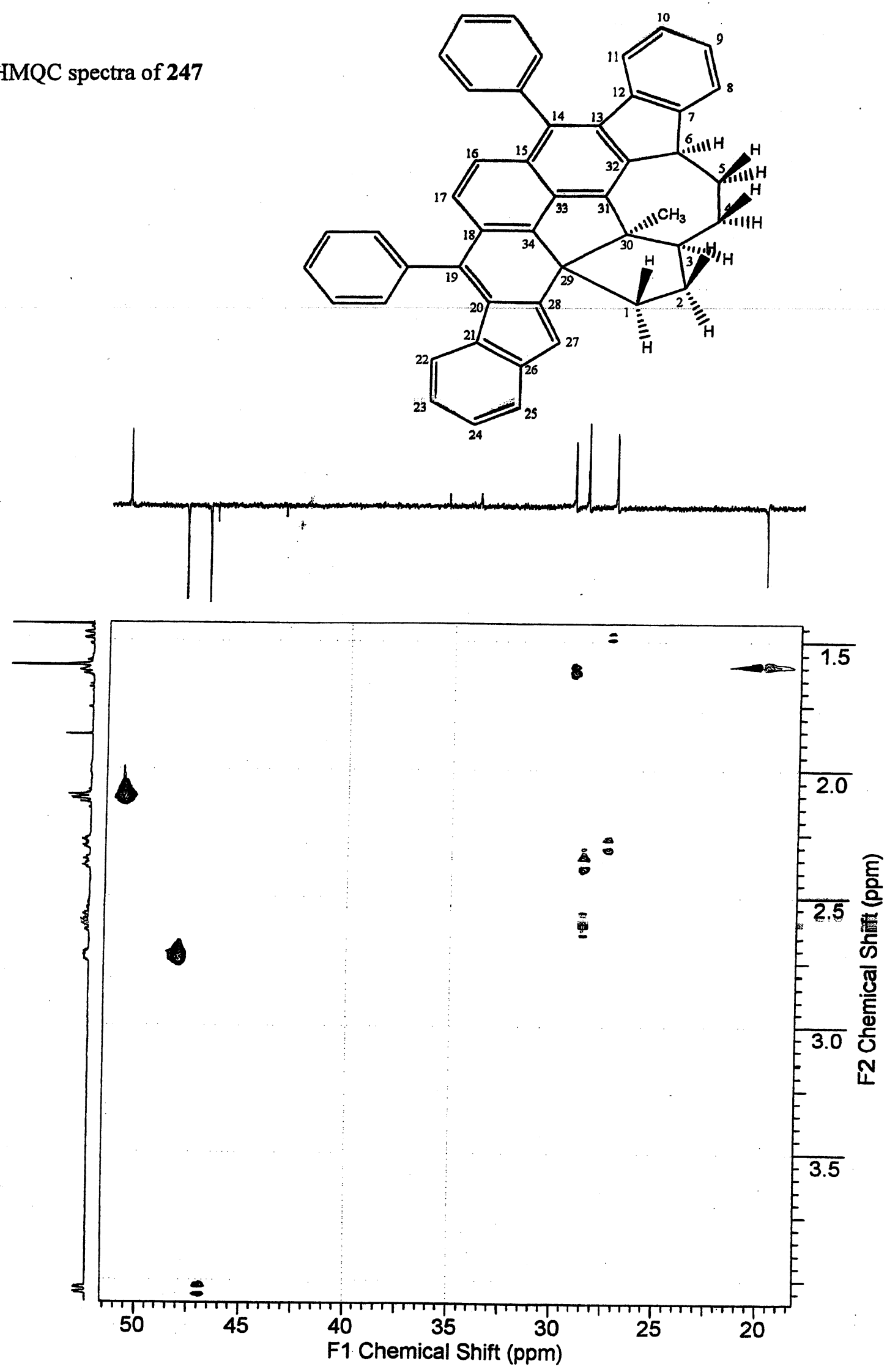
NOESY spectra of $\mathbf{2 4 7}$
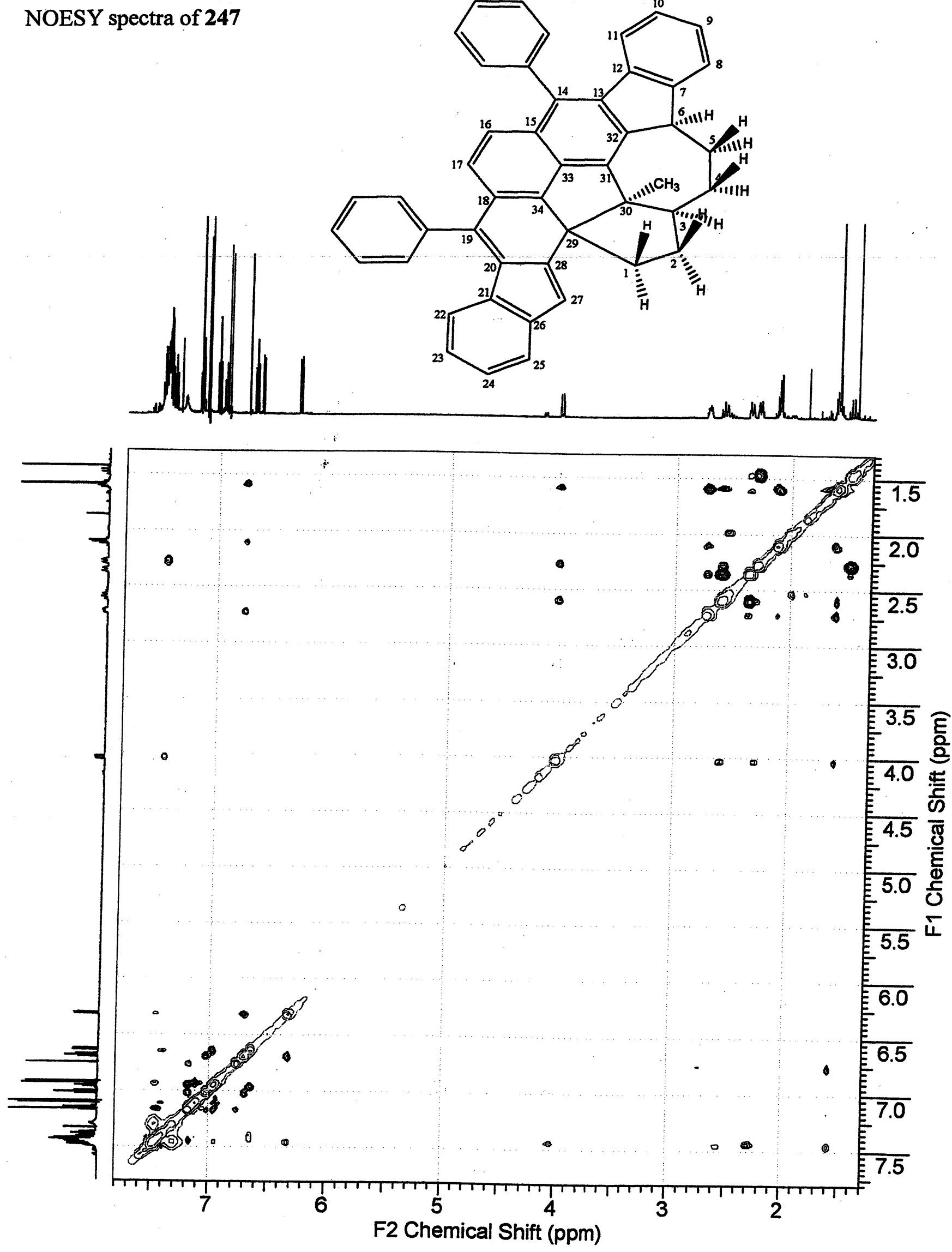


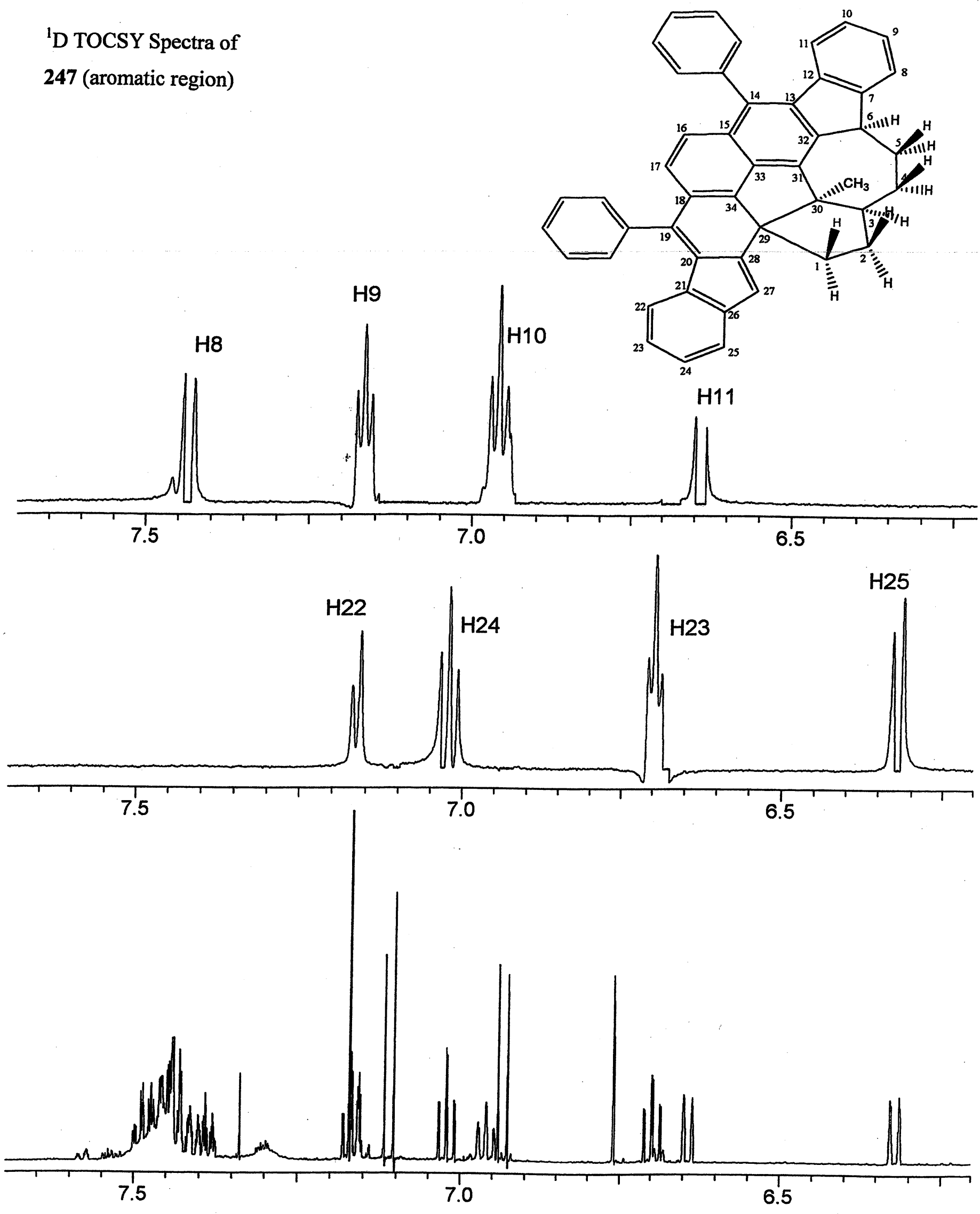


DPFGSE NOE spectra of

247 (aliphatic region)

H27
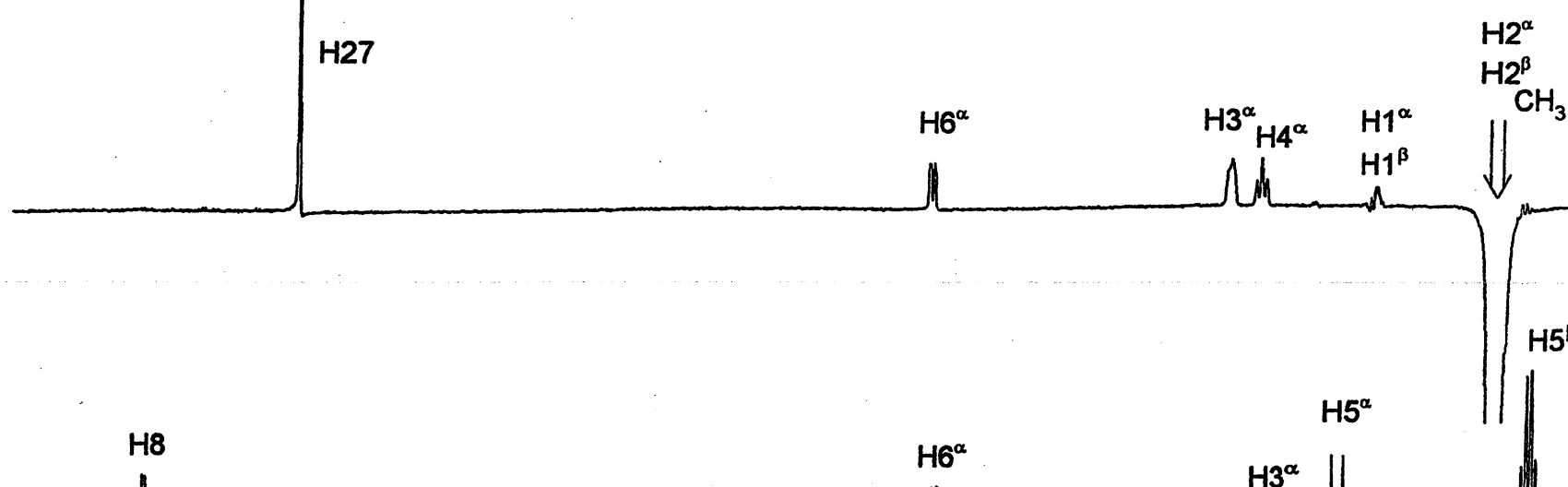

H8
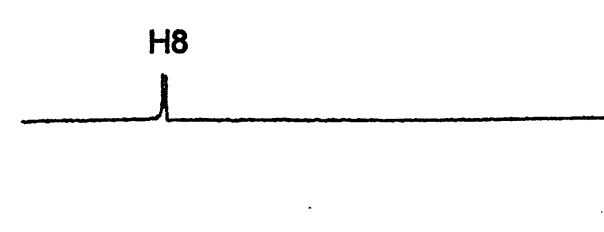

H27

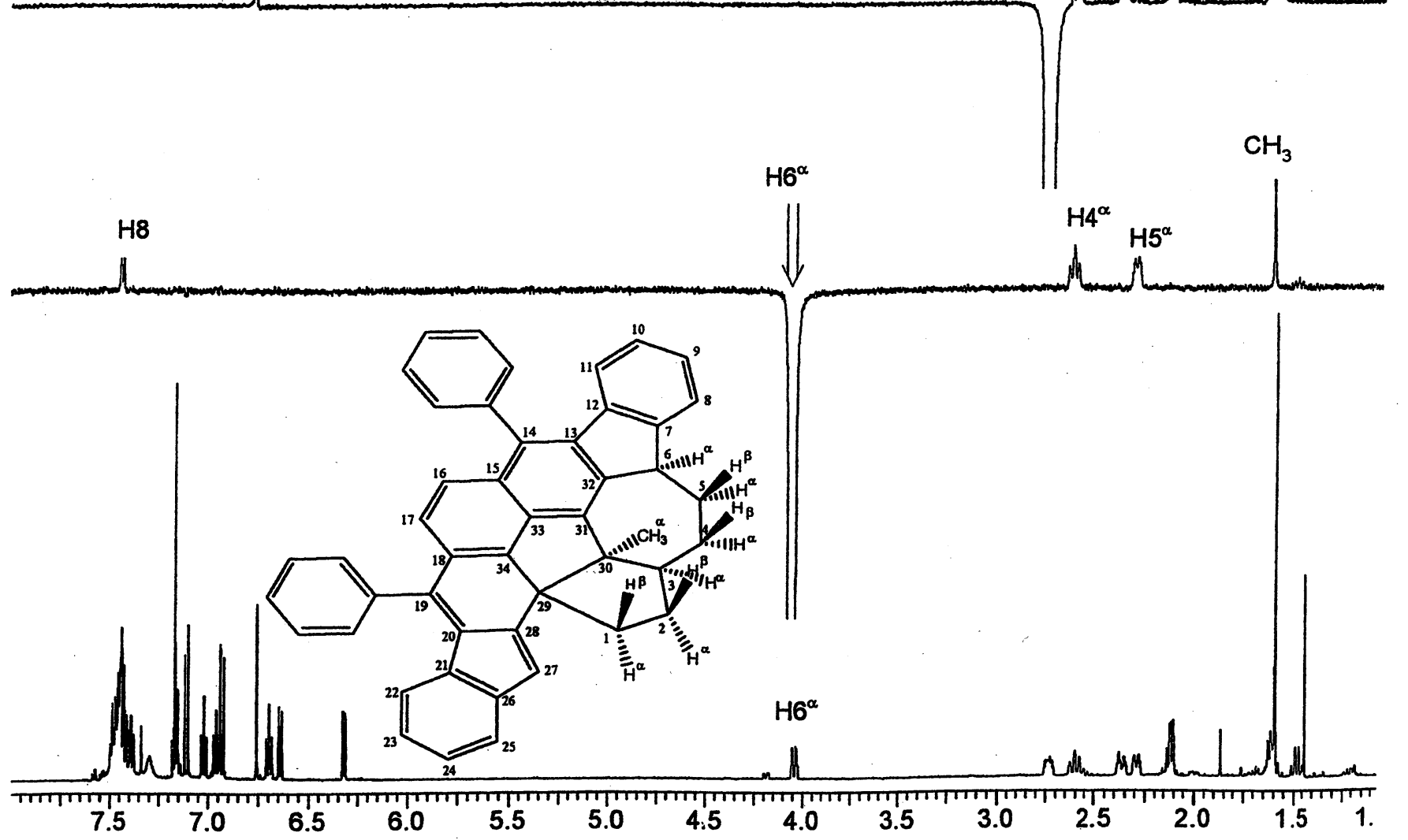


DPFGSE NOE spectra of

247 (aromatic region)

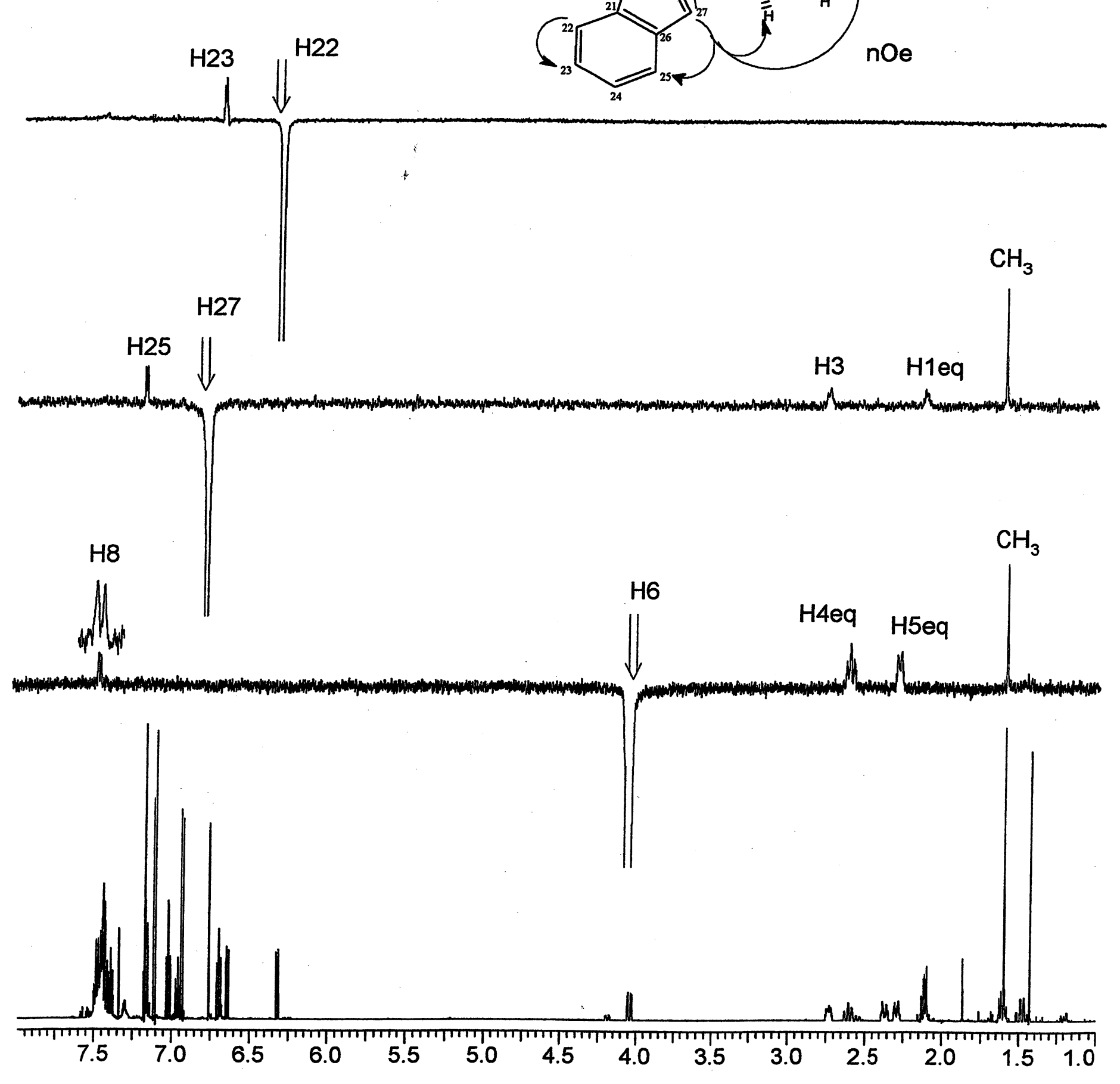




\section{DEPT spectra of $\mathbf{2 4 7}$}
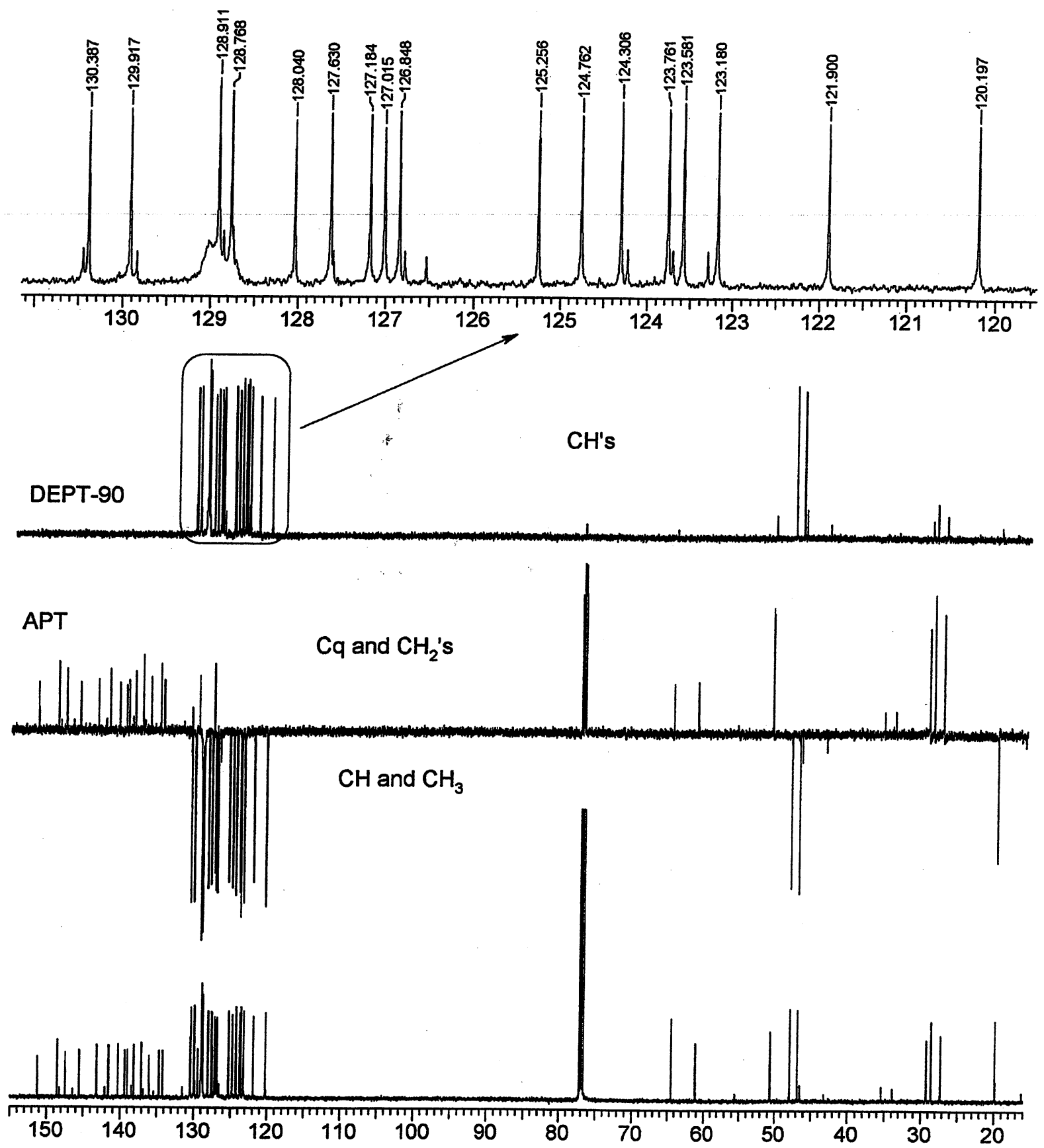


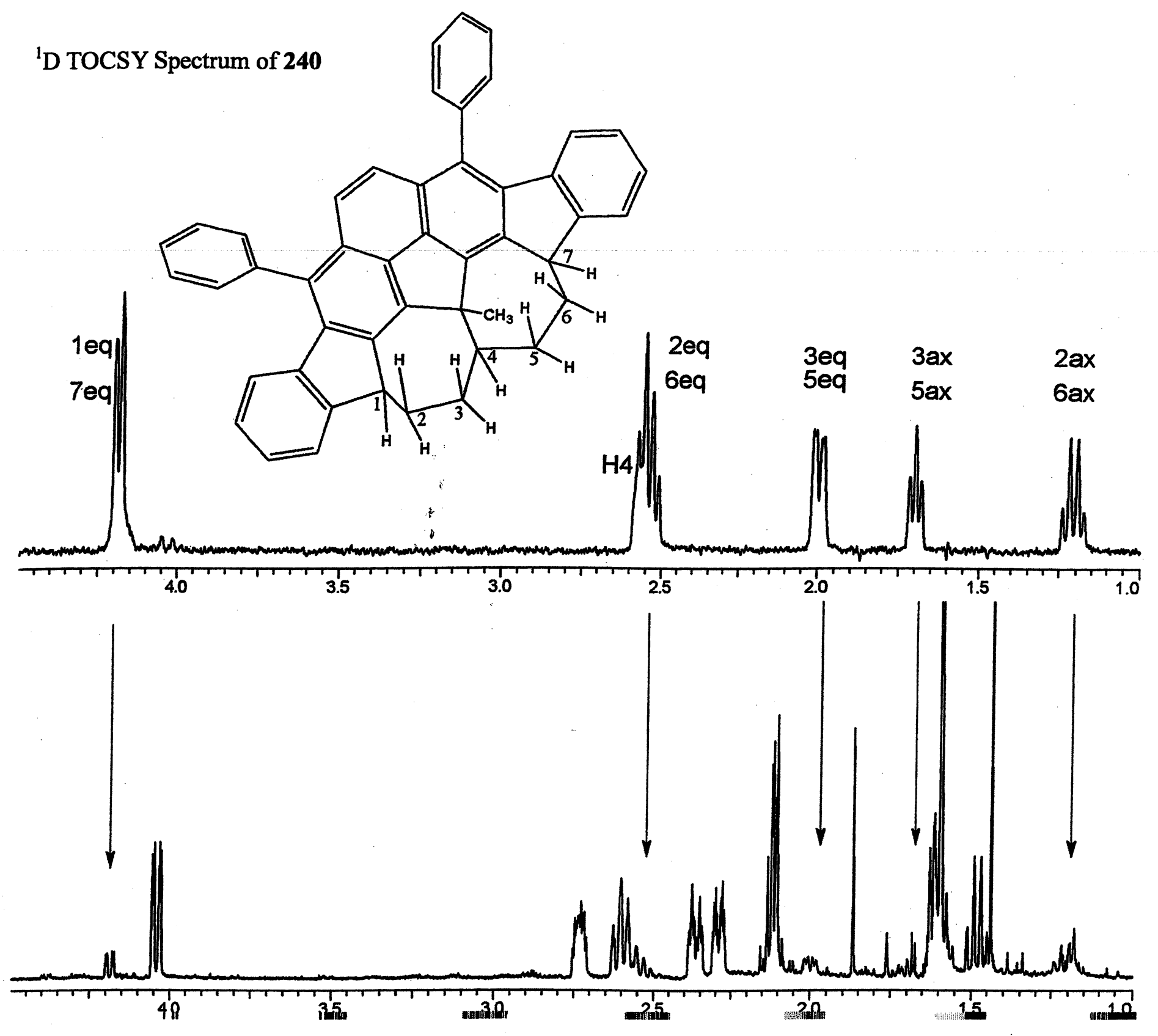


DPFGSE NOE spectrum of $\mathbf{2 4 0}$

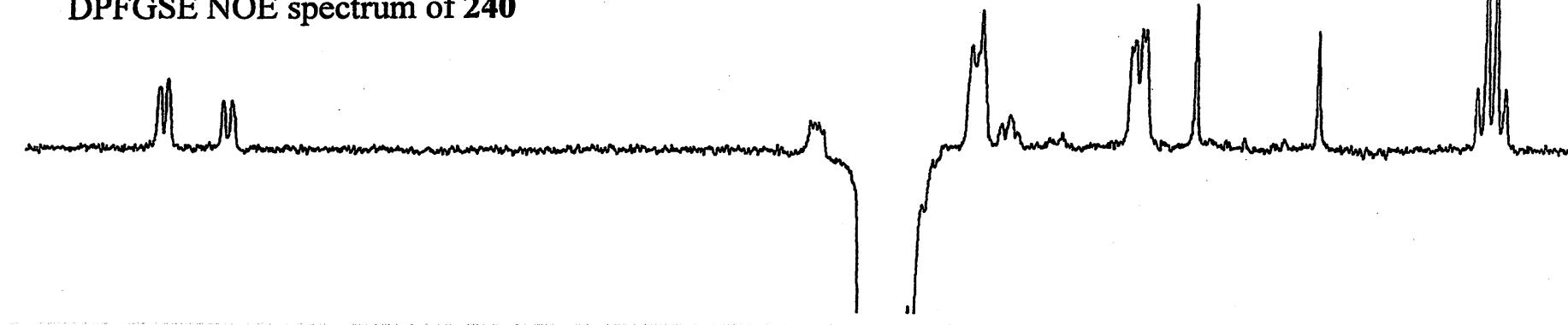

with 1 eq
7 eq

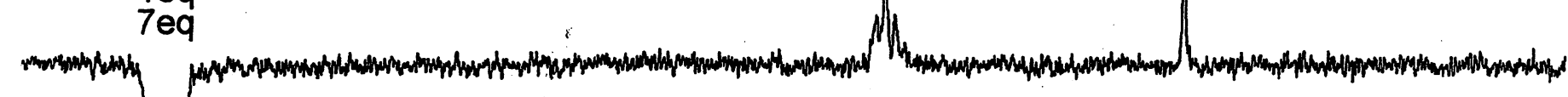
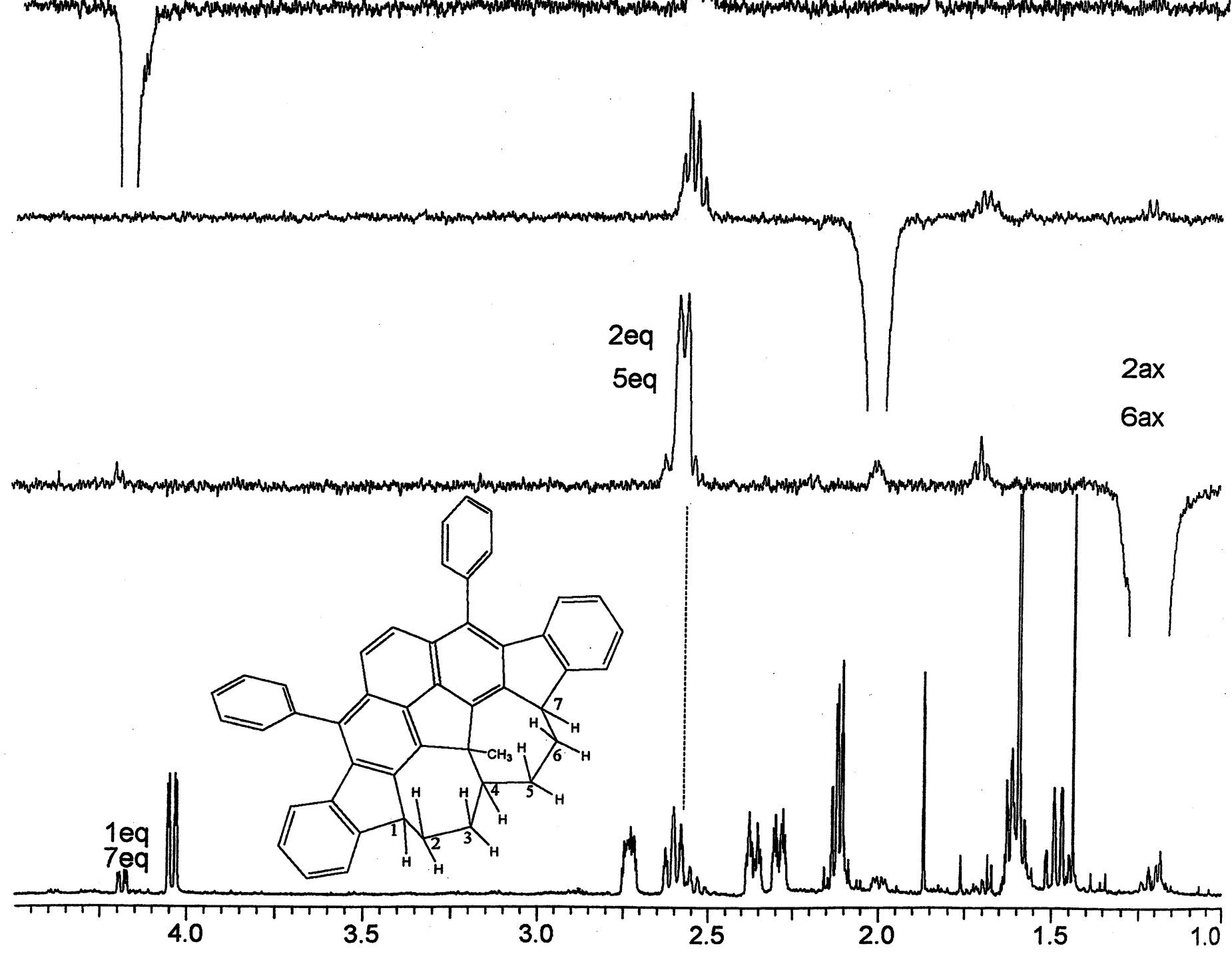


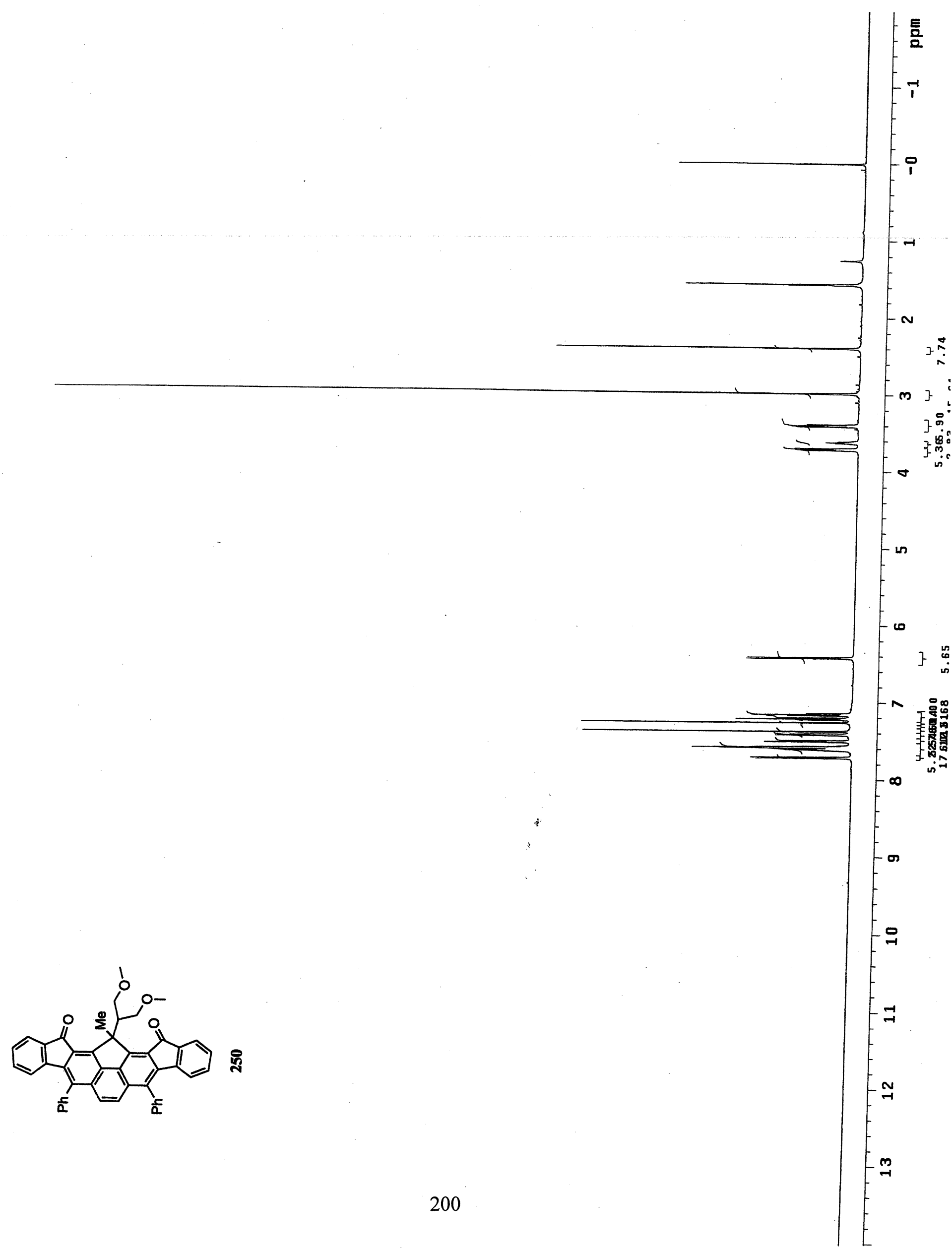




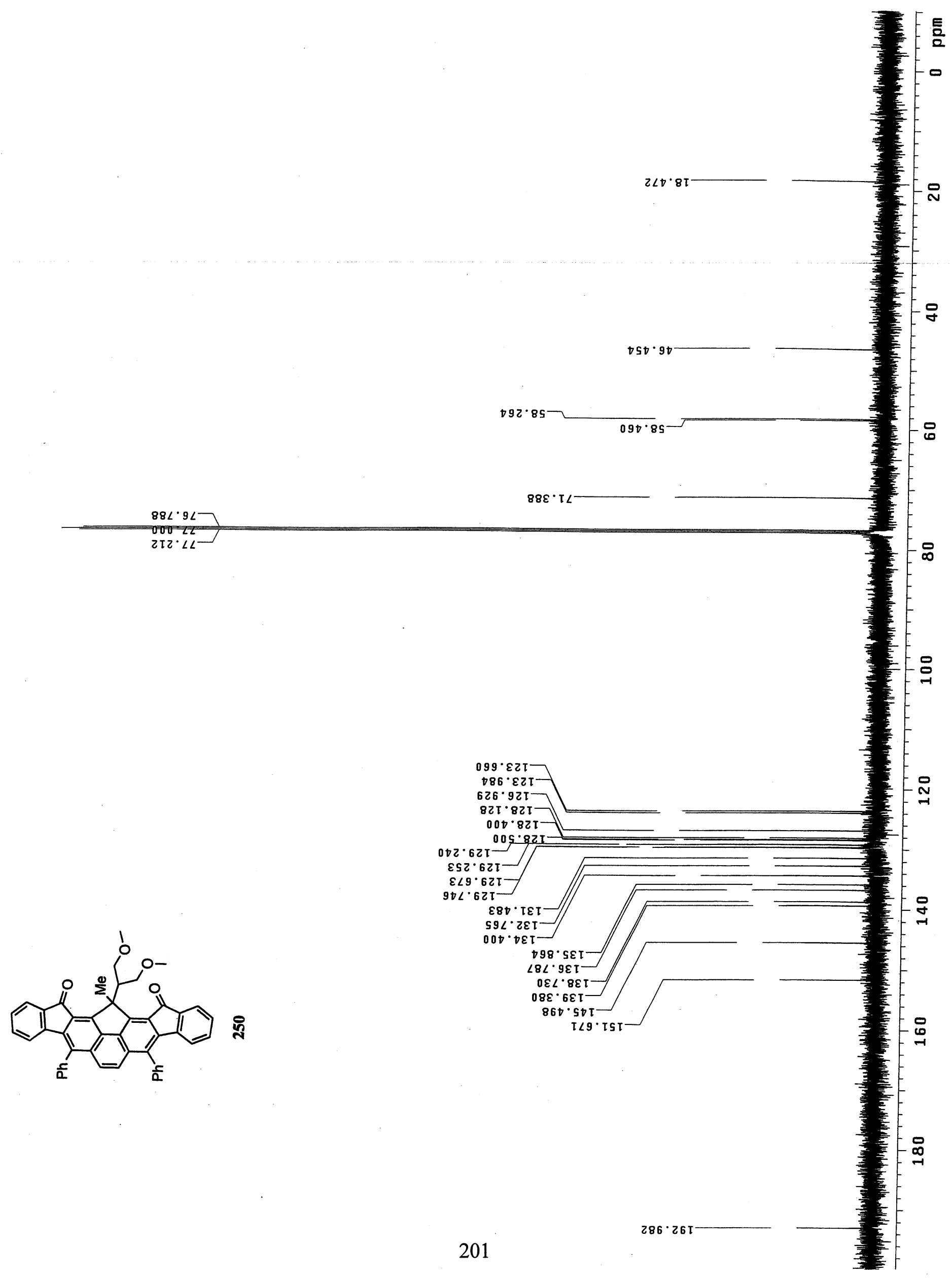




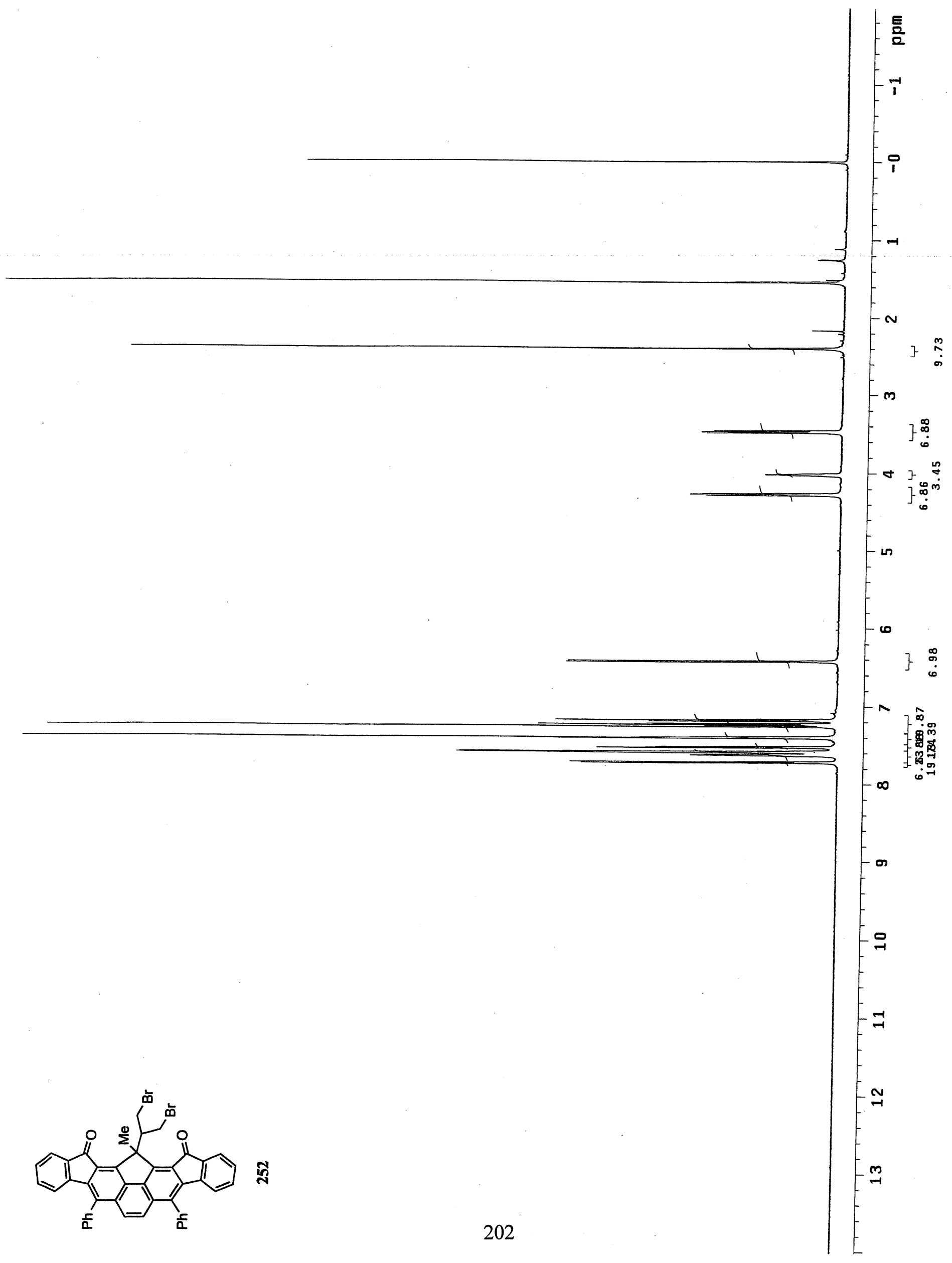




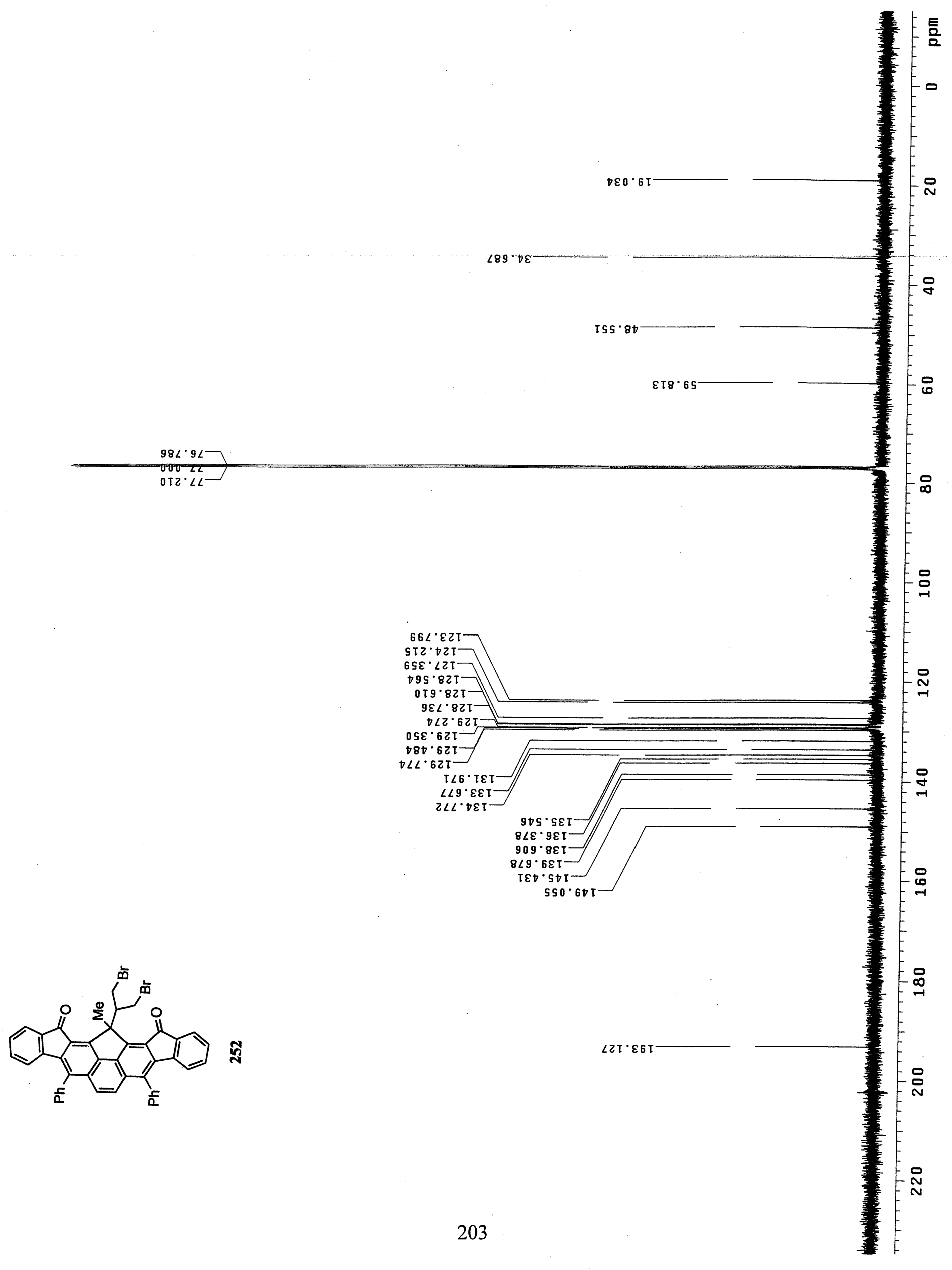




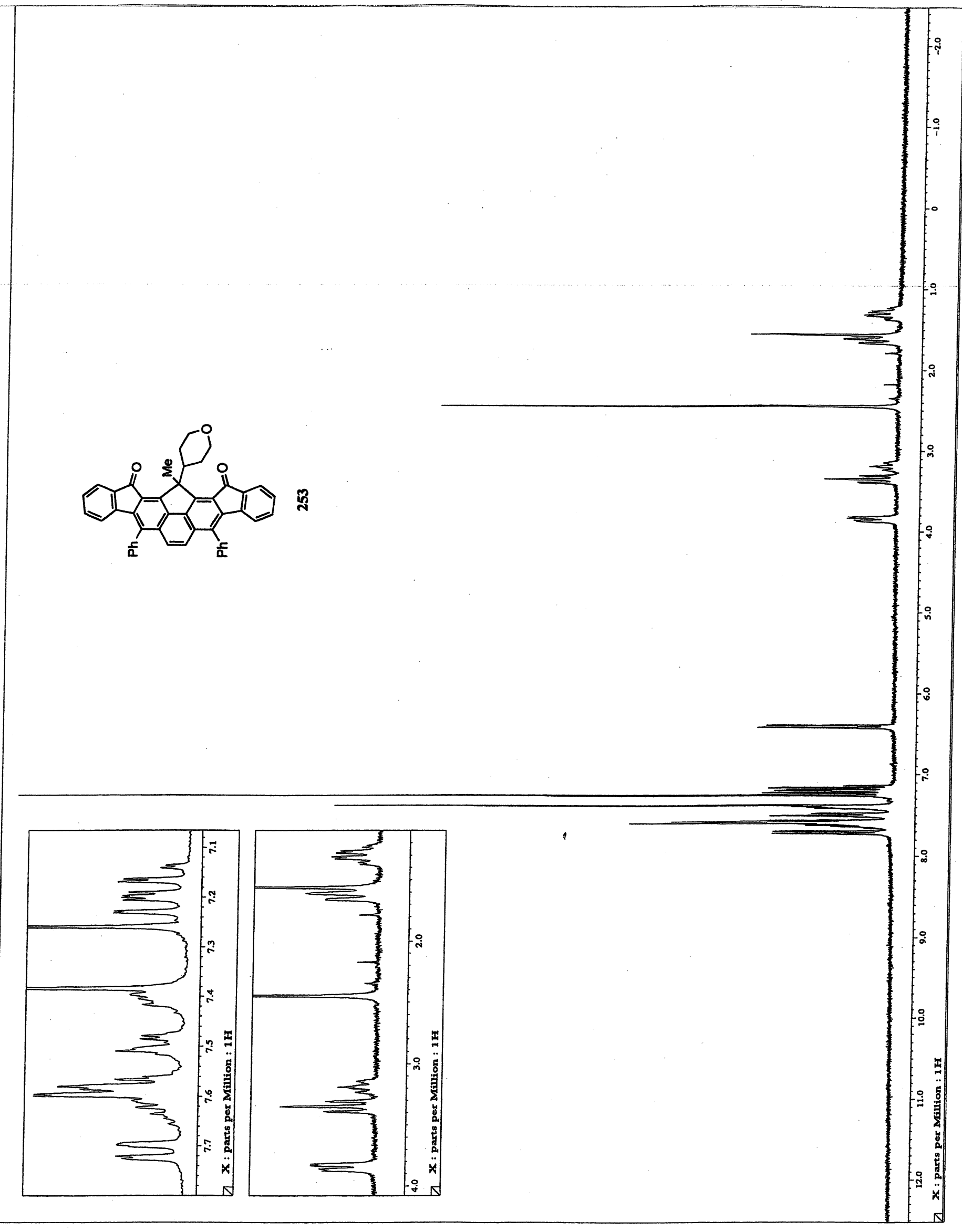




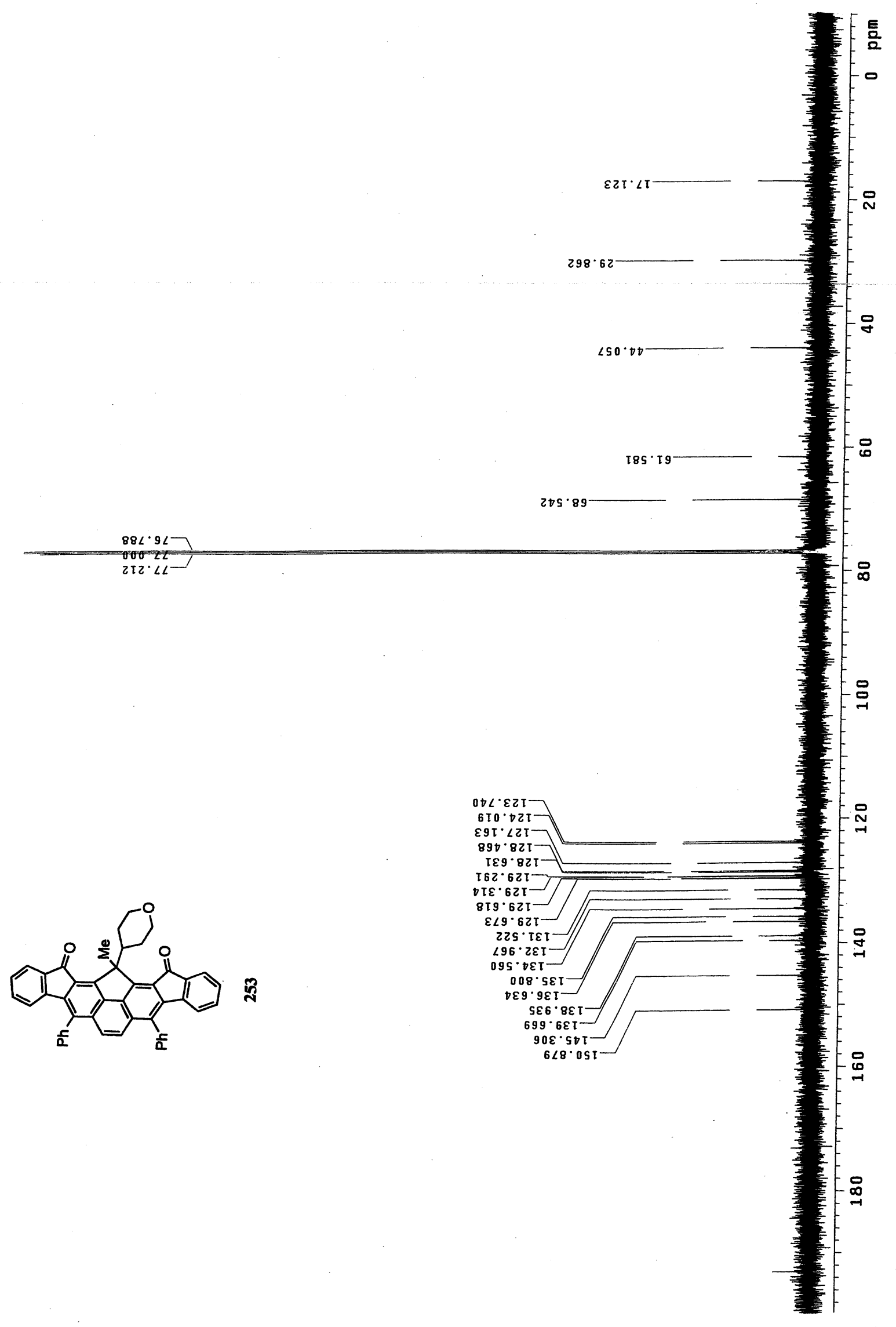




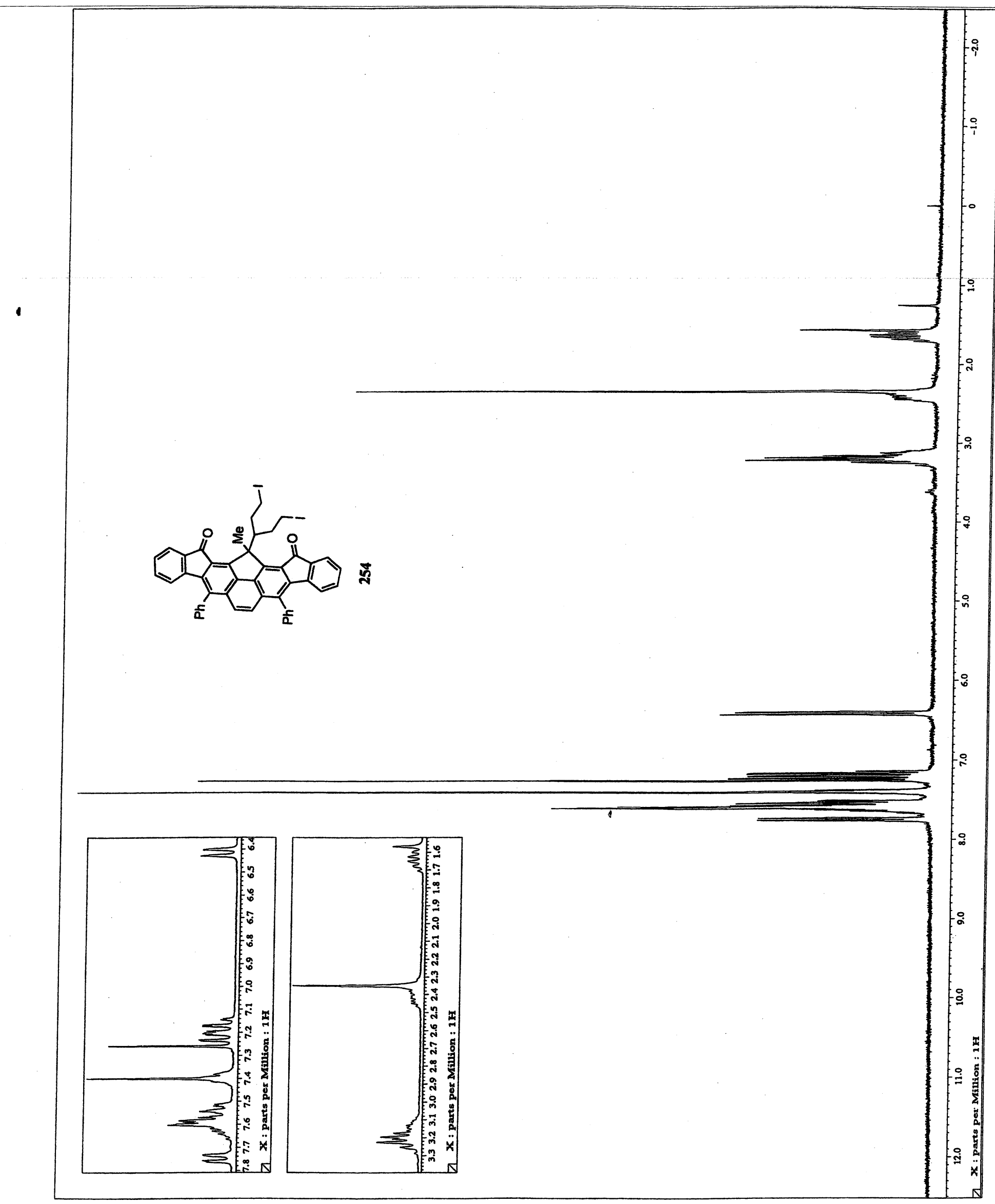




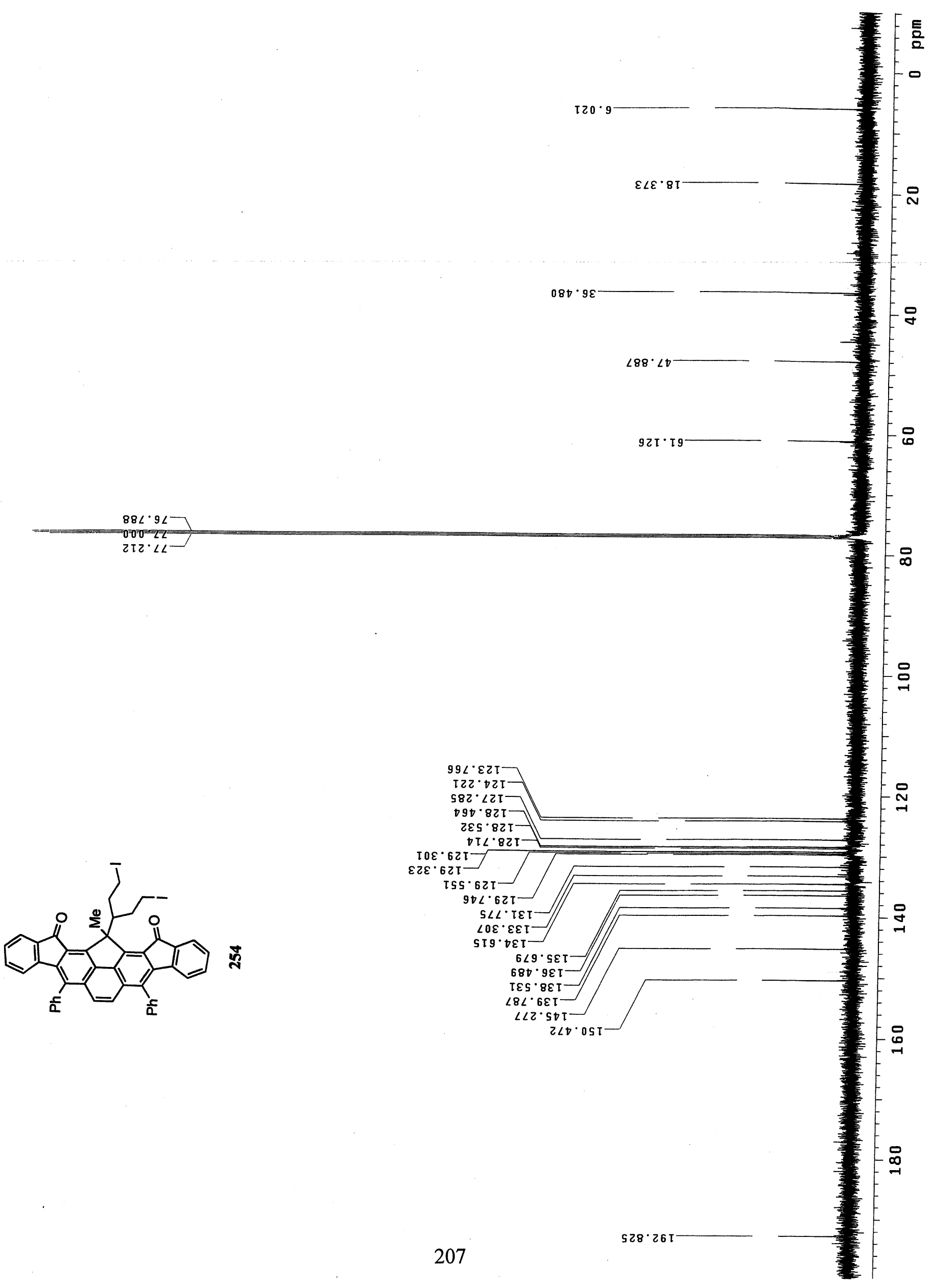




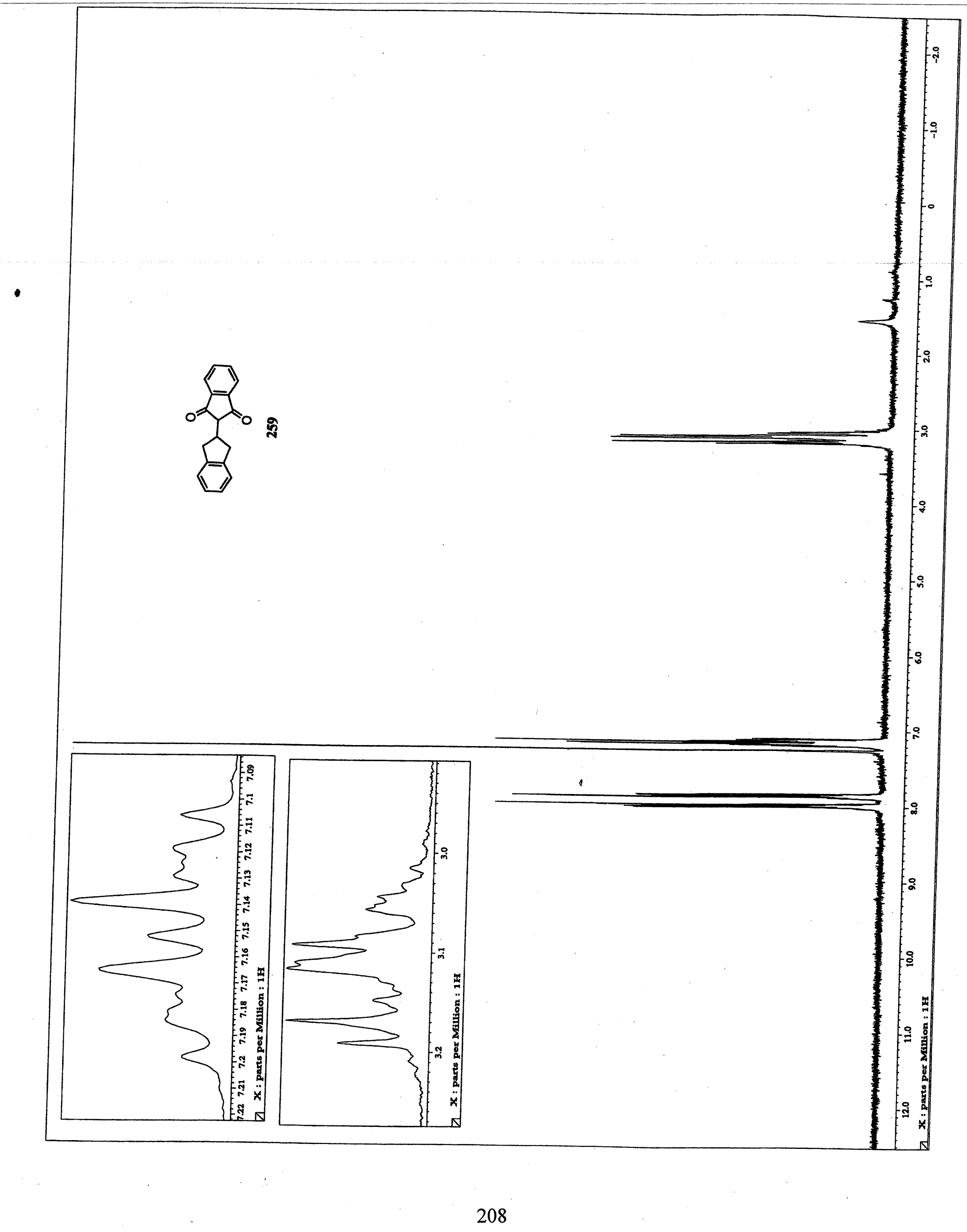




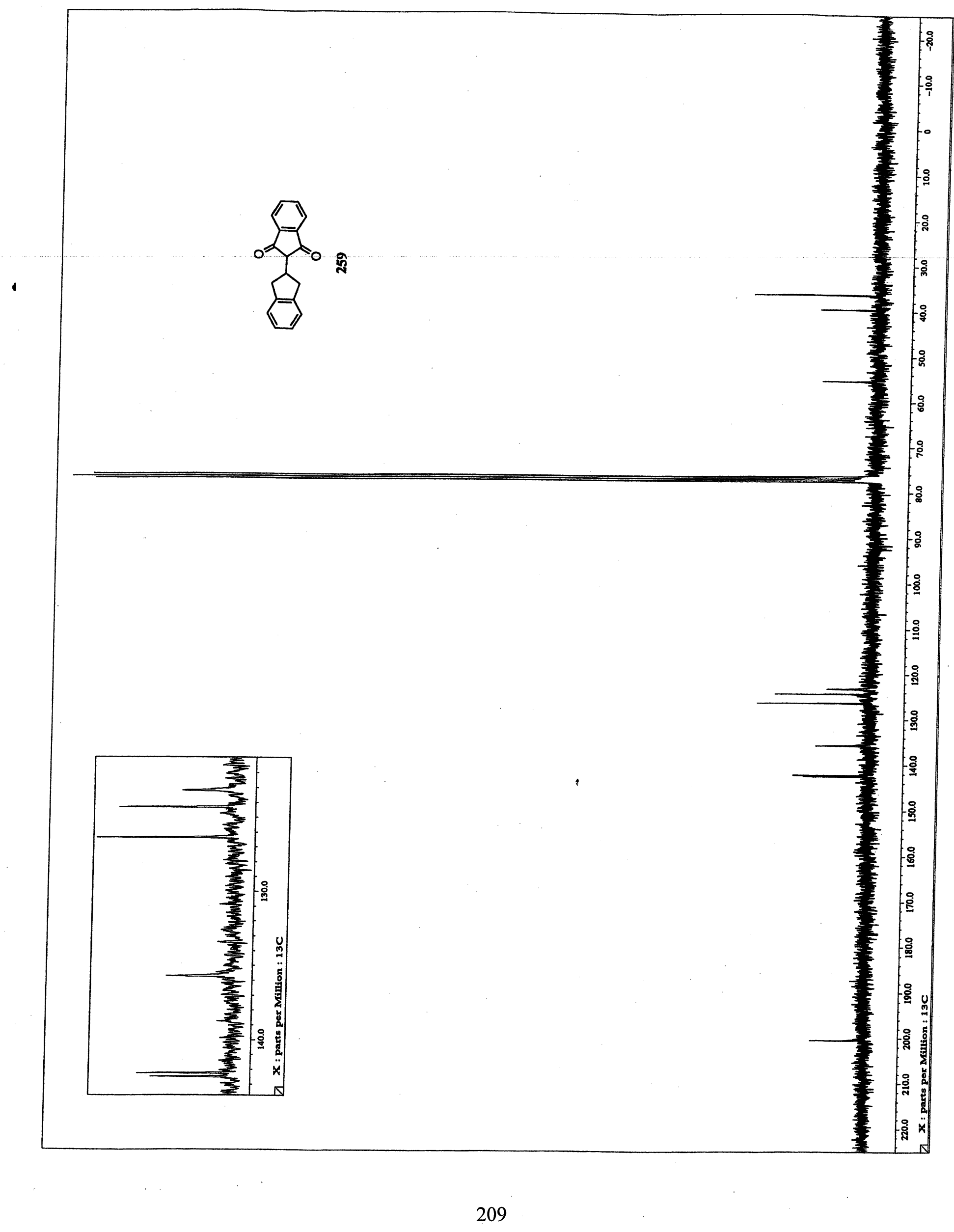




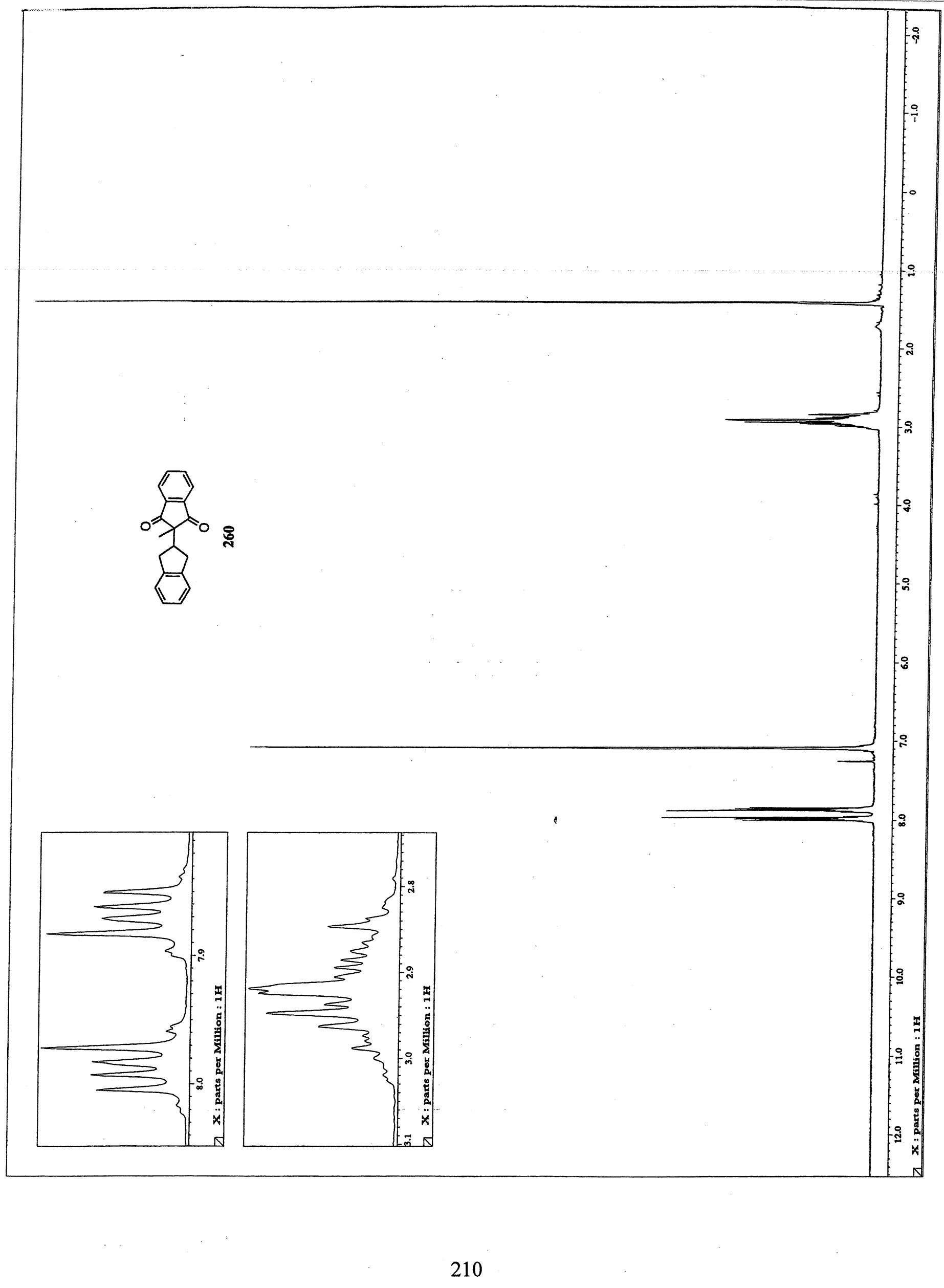




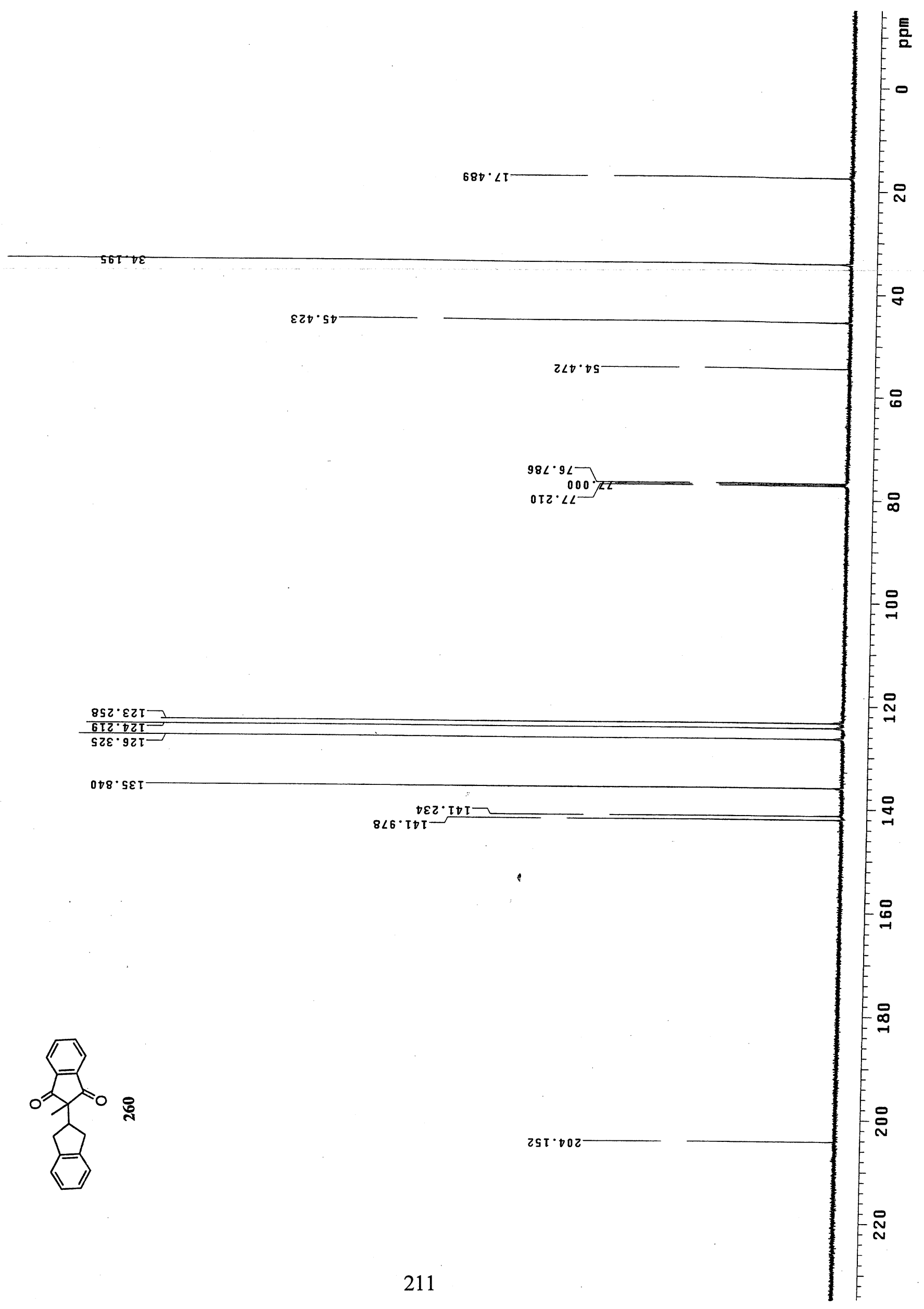




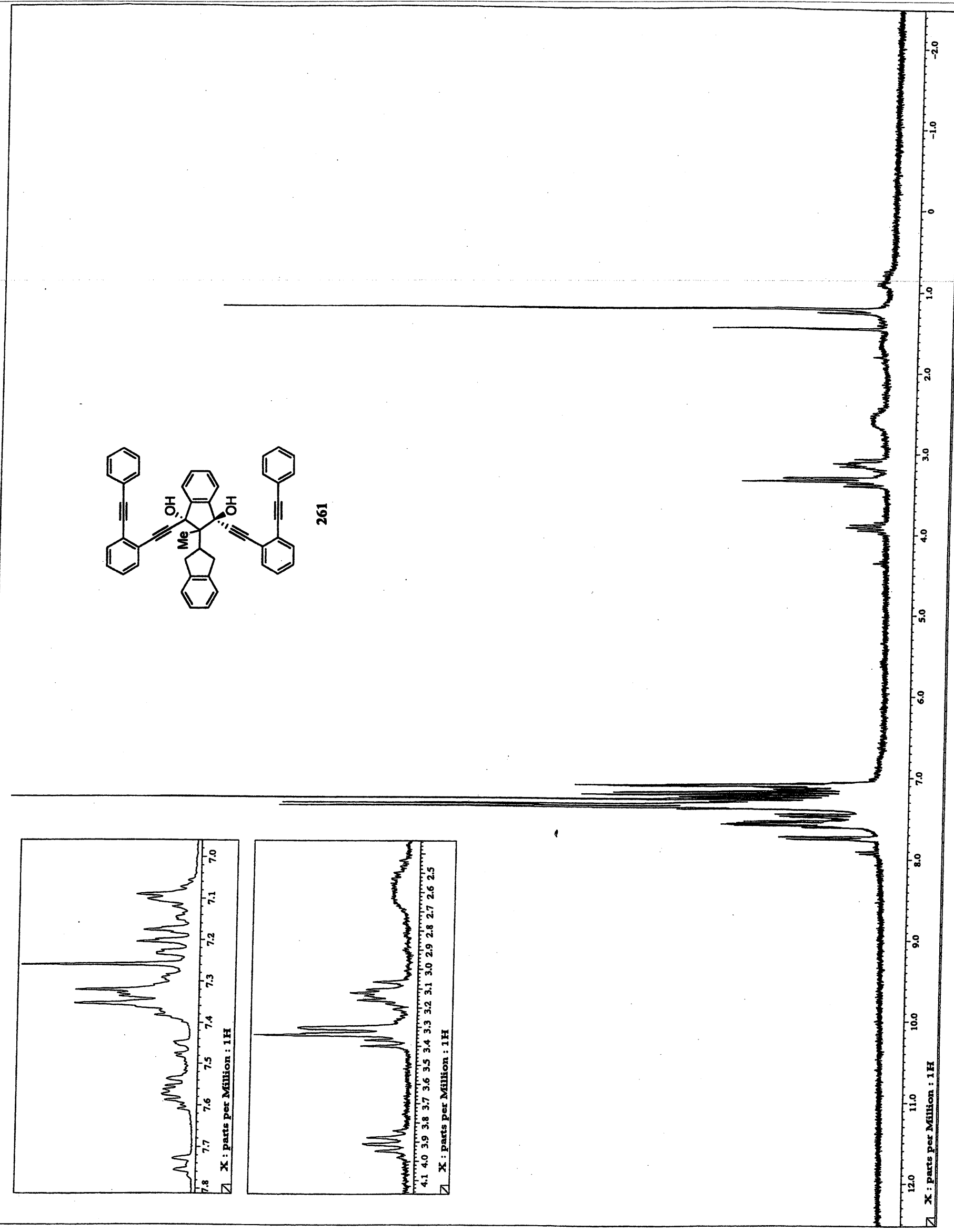




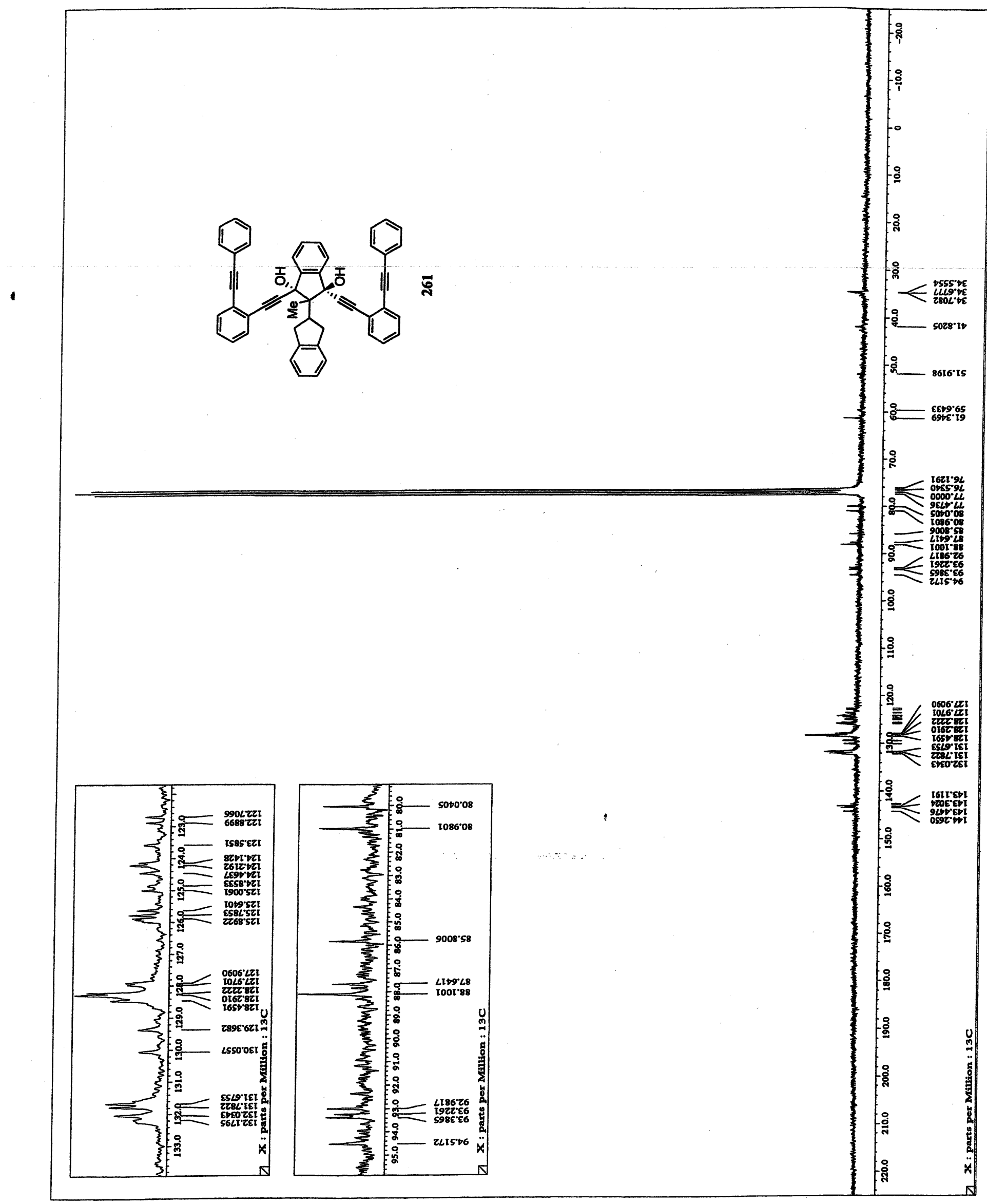




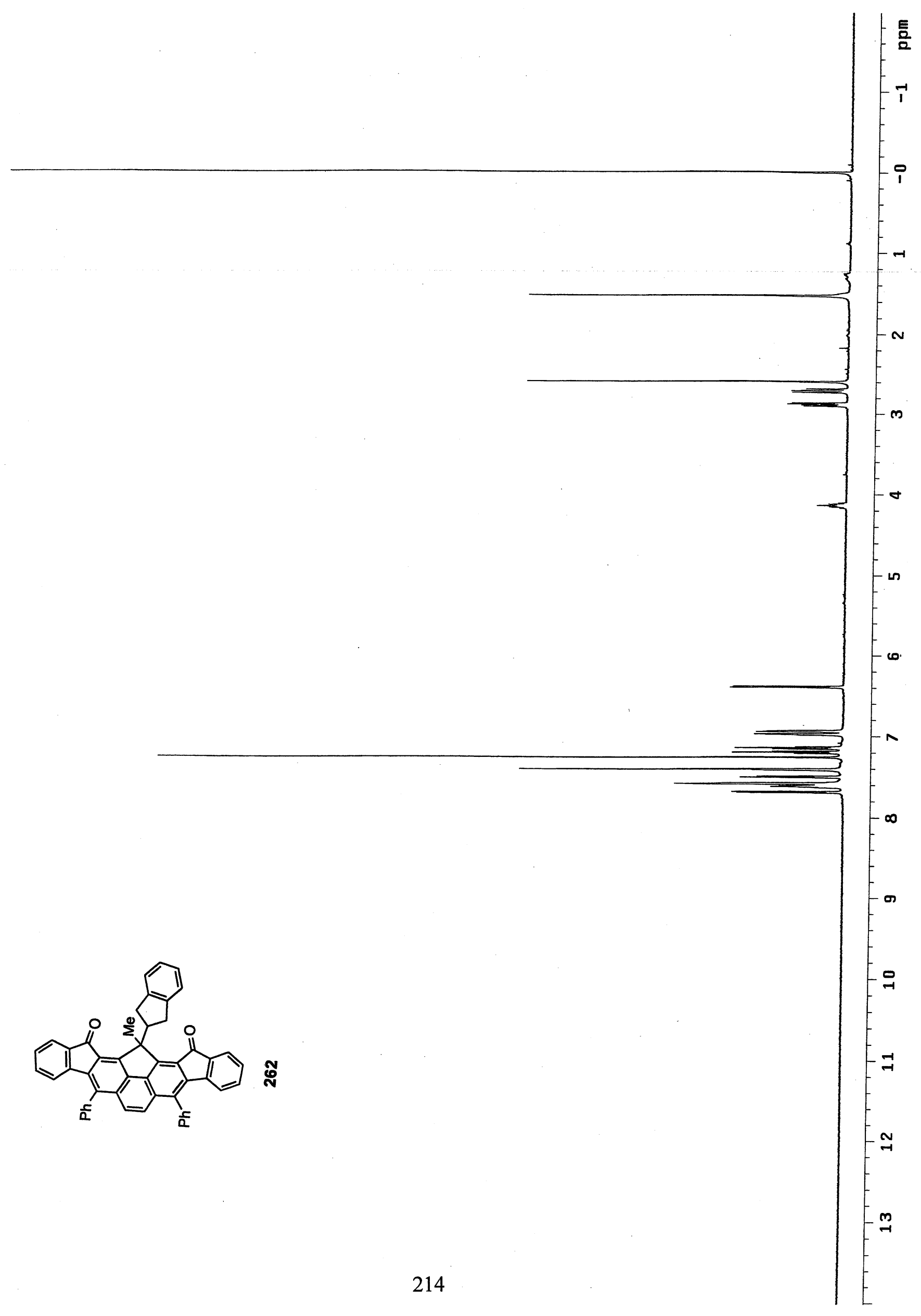




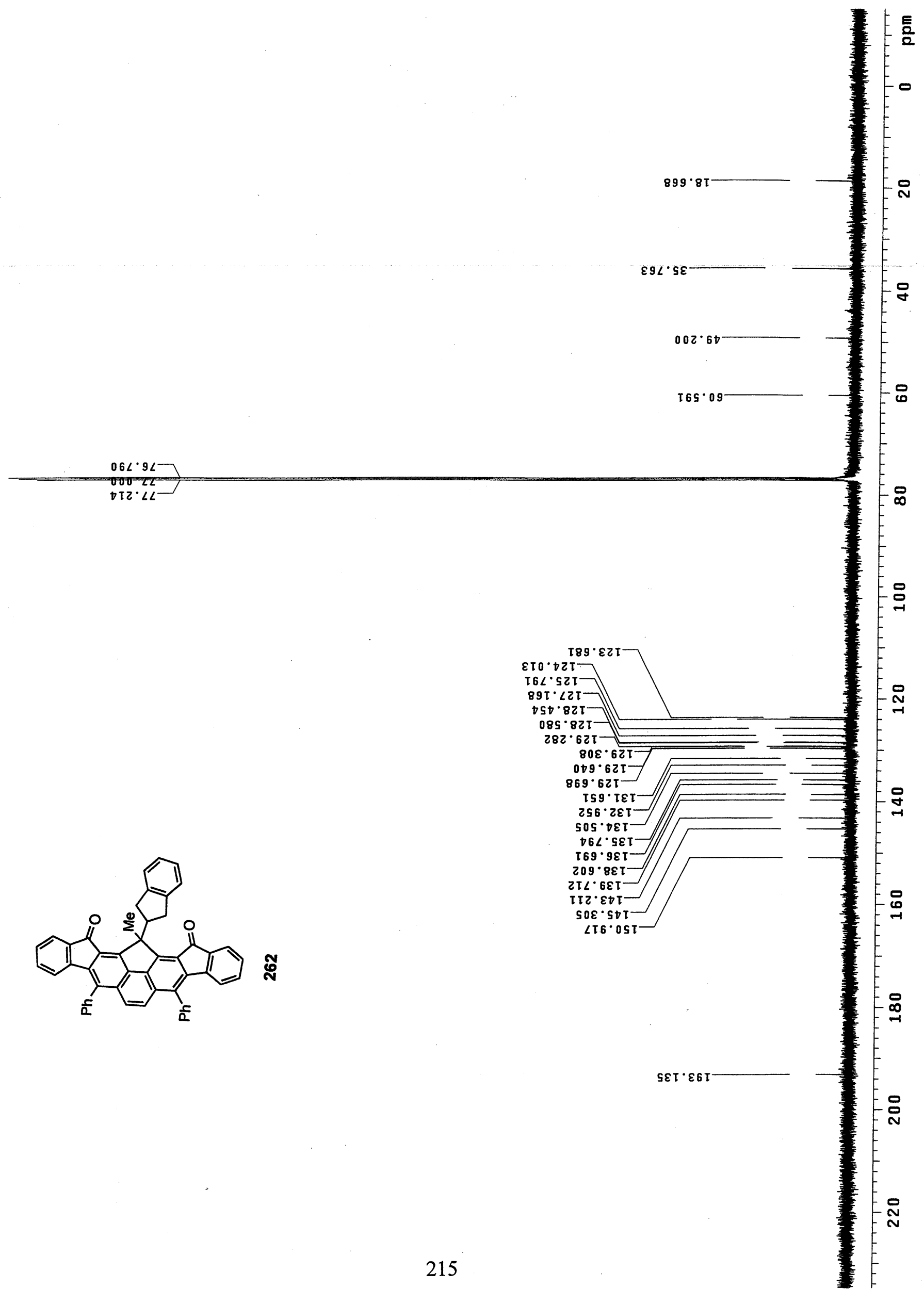

